$$
\text { ||f } 1 \text { th }
$$

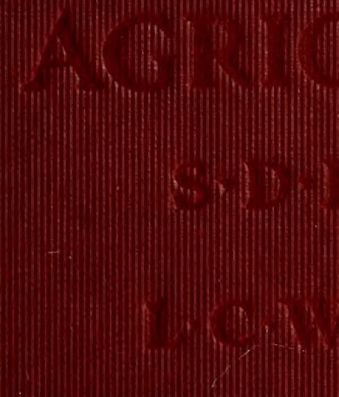




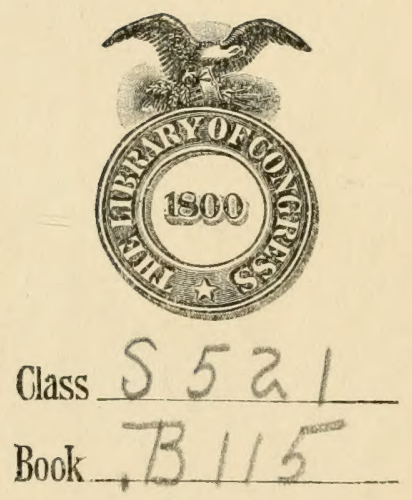

Copyrightt $\mathrm{N}^{0}$.

COPYRIGHT DEPOSR: 




\section{ESSAYS ON AGRICULTURE}





\section{ESSAYS \\ ON AGRICULTURE}

EDITED BY

SHIRLEY DARE BABBITT

Head Department of English

L. C. Smith School of Applied Science Syracuse University

AND

LOWRY CHARLES WIMBERLY

Instructor in English, University

of Nebraska

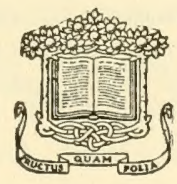

GARDEN CITY, N.Y., AND TORONTO

DOUBLEDAY, PAGE \& COMPANY 1921 


$$
95 \text { B }^{1} 115
$$

COPYRIGHT, 1921, BY DOUBLEDAY, PAGE \& COMPANY ALL RIGHTS RESERVED, INCLUDING THAT OF TRANSLATION INTO FOREIGN LANGUAGES, INCLUDLNG THE SCANDINAVIAN

\title{
()) 4630273
}

\author{
NOV 141921
}




\section{ACKNOWLEDGMENT}

THE editors wish to take this opportunity to thank both authors and publishers for permission to reprint the essays in this book. It is also their desire to express their gratitude for the help and encouragement given them by Dr. Louise Pound of the Department of English, University of Nebraska, and Dean E. A. Burnett of the College of Agriculture, University of Nebraska. 



\section{CONTEN'TS}

INTRODUCTION . . . . . . . . . ix

\section{THE DIGNITY OF FARMING}

II. Tire Holx EartiI . . Liberty H. Bailey 14

III. The Love of Nature - Mrs. Schuyler Van

Rensselaer

IV. Cinc ART . . . . Frank Waugh

V. The Art of Gardening Mrs. Schuyler Van Rensselaer

VI. Culture and Agricut,TURE . . . . H. W. Howe

\section{THE FARMER OF THE PRESENT}

Vii. The Farmer: The CorNer-Stone of CivilizaTION. . . . Theodore Roosevelt 79

VIII. The New Farmer . Kenyon L. Butterfield 91

IX. The New Call to the FARM ...... T. Bayard Collins 101

X. The Probleys of ProGRESS ...... Kenyon L. Butterfield 116

XI. Tire Nature of the ProBLEM . - . . Liberty H. Bailey

XII. The Man Who Wonks witi His HaNDs. Theodore Roosevelt

\section{THE FARMER AS A MAN OF BUSINESS}

XIV. Business Methods iN

$$
\text { Farming . . . Oscar H. Benson }
$$

XV. Farm Management - A

$$
\text { New Scirace. . . W. J. Spillman }
$$

XVI. How tIIF Government

WORKS WITH TIIE

Farmer . . . David $k$. Houston

XVII. Principles of Europeas

$$
\text { LaNd Credits . . Dick T. Murgan }
$$

XVIII. Renucing tire Cost of

$$
\text { Laving - A Common }
$$

Problfis . . . Edwin T. Meredith

XIX. Agriculturai Riadjust-

MENT AND THE HigI

Cost of Living. . Herbert Hoover 


\section{THE FARMER AS A SCIENTIST}

XX. Truumph of Scientific

$$
\text { Agriculture . . George W. Fiske } 269
$$

XXI. ON the Physical B isis

of LIFE . . . . . Thomas H. Huxley 288

XXII. New Plant Immigrants David Fairchild 301

XXIII. Bacteria aNd SoIl Fen-

$$
\text { тіlity . . . P. E. Brown }
$$

XXIV. Worms aNd THE SoIL - Charles Darwin 325

XXV. The Struggle for Exist-

$$
\text { ENCE . . . . Thomas H. Huxley } 331
$$

XXVI. Electrictity Advancing

$$
\text { Fary Prosperity. . James Burton }
$$

XXVII. The Gasolixe Exgine on

$$
\text { THE FARM .... Xeno W. Putnam }
$$

\section{OUR FOREFATHERS AND FARMTNG}

XXVIII. The Rurat Socrates . H. C. Hirzel 359

XXIX. Extracts From a Diary George Washington $\mathbf{3 6 7}$

XXX. A LetTer to Thomas

JefFerson . . . George Washington

371

XXXI. Lincoly on Agriculture Abraham Lincoln

XXXII. The Exceliences of Agrt- 


\section{INTRODUCTION}

A воок of essays for use as illustrative material in courses in composition scarcely needs an apology. The specimen method has long since proved itself pedagogically sound, and an invaluable aid to those confronted with the problem of teaching others to write. Hence, the editors of the present collection of essays, addresses, and articles, for courses in composition in agricultural colleges, can, in a way, make no claim to originality. They feel a certain pride, however, in being among the first to attempt to extend the usefulness of a sound principle of pedagogy, and to infuse new blood, so to speak, into an old idea.

An idea or principle, however sound, is in danger of outliving its usefulness, unless it is given repeated and fresh application. Any system stands or falls in accordance with its adaptability to new conditions. Any plan of teaching becomes ineffective once it shows itself inflexible and incapable of growth. The present editors, after experience with many types of students, have felt for some time that the specimen-book, unless kept alive by contact with the demands of the hour, is in a fair way to share the fate of certain other academic traditions, and to become so much pedagogical lumber. It is liable, in other words, to become "class-worn," to become a commonplace, and thereby cease to make its presence felt. A recent textbook on English composition has gone so far as to taboo the traditional expres- 
sion, theme, as being stereotyped, and, because of its classroom associations, too unsuggestive of the practical problems of writing. The theme is to be written, of course, but not under that name, and is no longer to be recognized as a kind of writing peculiar to students and to text-books on rhetoric. It is in some such manner that the editors of "Essays on Agriculture" have come to regard the specimen method. An invaluable method, it must not be allowed to die of that academic inertia which always results from failure on the part of the instructor to appreciate those new problems which are constantly arising wherever there is life and progress.

A new problem, and one of vital import for the instructor in composition, is that of mecting the peculiar needs of the technical student. The recognition of agriculture as among the chief branches of modern learning, the growing tendency toward specialization in the field of agriculture, and the consequent enlargement of the curriculum of the college of agriculture, make it imperative that the instructor in even so general a subject as composition consult the requirements of the hour, and, if he is teaching agricultural students, recognize at once that his methods of teaching must take care of the special problems of such students. Old means, if employed here at all, must be employed under new and particular conditions. If the specimen method is indispensable in courses where the student is seeking only a general education, how, the question arises, may it be made most effective in courses where the aim of the student is more special? If it serves the purposes of the student of liberal arts, how may it best serve the purposes of the student of agriculture? It is through 
an earnest desire to answer this question satisfactorily for themselves and for others that the present editors have prepared "Essays on Agriculture."

As indicated above, the general purpose of this collection of essays is quite in keeping with the aims of other books of model selections for use in composition, and the editors feel safe in taking for granted that the instructor has a close familiarity with the specimen method. The study of composition through the analysis and imitation of effective pieces of style has had such vogue of late years, that material selected for such study takes its place immediately as an integral part of any practical course in writing. The essays in the present collection may be studied with a view to imitation from the standpoint of both form and content. The principles which underlie successful organization in writing may here be seen in operation. Systematic rhetoric is not to be decried; rather, it is presupposed, but the editors of "Essays on Agriculture" believe that the student of composition is not unlike the student of engineering, in that he learns a great deal when given an opportunity to hear the hum of machinery and to watch the actual "wheels go round." In addition to serving as examples of effective writing, the essays furnish an invaluable source for discussions and for stimulation of thought. They provide an extensive fund of laboratory material for oral and written discussion.

The instructor in composition feels that the battle is more than half won, if he can bring the student to the point of wanting to write. But because of the virtual identity of style and substance, of form and 
content, it is generally true that one does not have an impulse to write, unless one has something to say. It becomes the duty of the instructor, then, to help the beginning writer not only as regards expression, or mere form, but as regards ideas as well. It is the experience of most teachers that a student is quick to respond when in the presence of that which is familiar and interesting, but is, on the whole, apathetic and indifferent toward that which is remote and of no concern to him. Obviously, the student of agriculture is interested in agriculture. He likes to talk about the problems of farm life-the movement away from the country to the city, the best methods of farming, the successful management of an eighty-acre farm, the relation of the farmer to the government, or the place of the farm in the economic world. If he is so ready and so eager to talk about matters relating to agriculture, it should not be difficult to interest him in writing about such matters. It only remains to show him that the written word is quite as natural a means of expression as the spoken word. Like other people, the student of agriculture is reticent about that of which he knows nothing, but is communicative in regard to that which he knows.

"Essays on Agriculture" is an attempt to meet the student of agriculture on his own ground, an endeavor to obviate those many problems which invariably arise when the student is required to write about subjects which are unfamiliar and of no immediate concern to him. It is an effort to show the student of agriculture that he, too, has a place in the sun, to help him see that he has something to say, that he has an abundance of material ready at hand, a wealth of ideas eminently 
worthy of expression, to make him realize that not only does he have material and ideas, but also to make him see that agriculture is of enough significance to occupy his most careful attention, that it has occupied the attention of such thinkers as Emerson, Lincoln, and Washington, and that at the present time it is taking its proper and lofty place in the affairs of the world. It is an attempt, among other things, to make the student of agriculture believe in himself, and have faith in his calling; for without faith there can be no progress. The present editors feel that such a student will want to write, once he sees that his ideas are no less worthy of being spoken of and written about than are the ideas of the educator, the doctor, the preacher, the lawyer, or the man of business. The material for the present collection has been chosen with various requirements in mind. Some of the essays have historical interest; some are literary in character; others are quite technical or scientific; most of them, as is to be expected in a book of this kind, are of a widely practical nature. On the whole, an effort has been made to glean articles which would be, not only of instructive, but of inspirational value as well. Touching as it does, then, in one way or another, upon the general matters of agriculture, this book should help the student of agriculture approach the problems of life from his own point of view, should aid him in realizing his fundamental relation to his fellow-man, and should encourage and guide him in interpreting, in his own way, these problems and this relationship. 

THE DIGNITY OF FARMING 



\section{I}

\section{FARMING*}

\section{Ralph Waldo Emerson}

The glory of the farmer is that, in the division of labors, it is his part to create. All trade rests at last on his primitive activity. He stands close to Nature; he obtains from the earth the bread and the meat. The food which was not, he causes to be. The farmer was the first man, and all historic nobility rests on possession and use of land. Men do not like hard work, but every man has an exceptional respect for tillage, and a feeling that this is the original calling of his race, that he himself is only excused from it by some circumstance which made him delegate it for a time to other hands. If he have not some skill which recommends him to the farmer, some product for which the farmer will give him corn, he must himself return into his due place among the planters. And the profession has in all eyes its ancient charm, as standing nearest to God, the first cause.

Then the beauty of Nature, the tranquillity and innocence of the countryman, his independence, and his pleasing arts, - the care of bees, of poultry, of sheep, of cows, the dairy, the care of hay, of fruits, of orchards and forests, and the reaction of these on the workman, in giving him a strength and plain dignity, like the face "From "Society and Solitude," by permission of Houghton Miflin 
and manners of Nature, all men acknowledge. All men keep the farm in reserve as an asylum where, in case of mischance, to hide their poverty, - or a solitude, if they do not succeed in society. And who knows how many glances of remorse are turned this way from the bankrupts of trade, from mortified pleaders in courts and senates, or from the victims of idleness and pleasure? Poisoned by town life and town vices, the sufferer resolves: "Well, my children, whom I have injured, shall go back to the land, to be recruited and cured by that which should have been my nursery, and now shall be their hospital."

The farmer's office is precise and important, but you must not try to paint him in rose-color; you cannot make pretty compliments to fate and gravitation, whose minister he is. He represents the necessities. It is the beauty of the great economy of the world that makes his comeliness. He bends to the order of the seasons, the weather, the soils and crops, as the sails of a ship bend to the wind. He represents continuous hard labor, year in, year out, and small gains. He is a slow person, timed to Nature, and not to city watches. He takes the pace of seasons, plants, and chemistry. Nature never hurries: atom by atom, little by little, she achieves her work. The lesson one learns in fishing, yachting, hunting, or planting, is the manners of Nature; patience with the delays of wind and sun, delays of the seasons, bad weather, excess or lack of water,--patience with the slowness of our feet, with the parsimony of our strength, with the largeness of sea and land we must traverse, etc. The farmer times himself to Nature, and acquires that livelong patience which belongs to her. Slow, narrow 
man, his rule is, that the earth shall feed and clothe him; and he must wait for his crop to grow. His entertainments, his liberties, and his spending must be on a farmer's scale, and not on a merchant's. It were as false for farmers to use a wholesale and massy expense, as for states to use a mimute economy. But if thus pinched on one side, he has compensatory advantages. He is permanent, clings to his land as the rocks do. In the town where I live, farms remain in the same families for seven and eight generations; and most of the first settlers (in 1635), should they reappear on the farms today, would find their own blood and names still in possession. And the like fact holds in the surrounding towns.

This hard work will always be done by one kind of man; not by scheming speculators, not by soldiers, nor professors, nor readers of Tennyson, but by men of endurance,-deep-chested, long-winded, tough, slow and sure, and timely. The farmer has a great health, and the appetite of health, and means to his end: he has broad lands for his home, wood to burn great fires, plenty of plain food; his milk, at least, is unwatered: and for sleep, he has cheaper and better and more of it than citizens.

He has grave trusts confided to him. In the great household of Nature, the farmer stands at the door of the bread-room, and weighs to each his loaf. It is for him to say whether men shall marry or not. Early marriages and the number of births are indissolubly connected with abundance of food; or, as Burke said, "Man breeds at the mouth." Then he is the Board of Quarantine. The farmer is a hoarded capital of health, 
as the farm is the capital of wealth; and it is from him that the health and power, moral and intellectual, of the cities came. The city is always recruited from the country. The men in cities who are the centers of energy, the driving-wheels of trade, politics, or practical arts, and the women of beauty and genius are the children or grandchildren of farmers, and are spending the energies which their fathers' hardy, silent life accumulated in frosty furrows, in poverty, necessity, and darkness.

He is the continuous benefactor. He who digs a well, constructs a stone fountain, plants a grove of trees by the roadside, plants an orchard, builds a durable house, reclaims a swamp, or so much as puts a stone seat by the wayside, makes the land so far lovely and desirable, makes a fortune which he cannot carry away with him, but which is uscful to his country long afterwards. The man that works at home helps socicty at large with somewhat more of certainty than he who devotes himself to charities. If it be true that, not by votes of political parties, but by the eternal laws of political economy, slaves are driven out of a slave State as fast as it is surrounded by free States, then the true abolitionist is the farmer, who, heedless of laws and constitutions, stands all day in the field, investing his labor in the land, and making a product with which no forced labor can compete.

We commonly say that the rich man can speak the truth, can afford honesty, can afford independence of opinion and action;--and that is the theory of nobility. But it is the rich man in a true sense, that is to say, not the man of large income and large expenditure, but 
solely the man whose outlay is less than his income and is steadily kept so.

In English factories, the boy that watches the loom, to tie the thread when the wheel stops to indicate that a thread is broken, is called a minder. And in this great factory of our Copernican globe, shifting its slides, rotating its constellations, times, and tides, bringing now the day of planting, then of watering, then of weeding, then of reaping, then of curing and storing, - the farmer is the minder. His machine is of colossal proportions, --the diameter of the water-wheel, the arms of the levers, the power of the battery, are out of all mechanic measure; - and it takes him long to understand its parts and its working. This pump never "sucks"; these screws are never loose; this machine is never out of gear; the vat and piston, wheels and tires, never wear out, but are self-repairing.

Who are the farner's servants? Not the Irish, nor the coolies, but Geology and Chemistry, the quarry of the air, the water of the brook, the lightning of the cloud, the castings of the worm, the plough of the frost. Long before he was born, the sun of ages decomposed the racks, mellowed his land, soaked it with light and heat, covered it with vegetable film, then with forests, and accumulated the sphagnum whose decays made the peat of his meadow.

Science has shown the great circles in which Nature works; the manner in which marine plants balance the marine animals, as the land plants supply the oxygen which the animals consume, and the animals the carbon which the plants absorb. These activities are incessant. Nature works on a method of all for each and each for 
all. The strain that is made on one point bears on every arch and foundation of the structure. There is a perfect solidarity. You cannot detach an atom from its holdings, or strip off from it the electricity, gravitation, chemic affinity, or the relation to light and heat, and leave the atom bare. No, it brings with it its universal ties.

Nature, like a cautious testator, ties up her estate, so as not to bestow it all on one generation, but has a forelooking tenderness and equal regard to the next and the next, and the fourth, and the fortieth age.

There lie the inexhaustible magazines. The eternal rocks, as we call them, have held their oxygen or lime undiminished, entire as it was. No particle of oxygen can rust or wear, but has the same energy as on the first morning. The good rocks, those patient waiters, say to him: "We have the sacred power as we received it. We have not failed of our trust, and now-when in our immense day the hour is at last struck-take the gas we have hoarded; mingle it with water; and let it be free to grow in plants and animals, and obey the thought of man."

The earth works for him; the earth is a machine which yields almost gratuitous service to every application of intellect. Every plant is a manufacturer of soil. In the stomach of the plant development begins. The tree can draw on the whole air, the whole earth, on all the rolling main. The plant is all suction-pipe,imbibing from the ground by its root, from the air by its leaves, with all its might.

The air works for him. The atmosphere, a sharp solvent, drinks the essence and spirit of every solid on the globe,-menstruum which melts the mountains into it. 
Air is matter subdued by heat. As the sea is the grand receptacle of all rivers, so the air is the receptacle from which all things spring, and into which they all return. The invisible and creeping air takes form and solid mass. Our senses are sceptics, and believe only the impression of the moment, and do not believe the chemical fact that these huge mountain-chains are made up of gases and rolling wind. But Nature is as subtle as she is strong. She turns her capital day by day; deals never with dead, but ever with quick subjects. All things are flowing, even those that seem immovable. The adamant is always passing into smoke. The plants imbibe the materials which they want from the air and the ground. They burn, that is, exhale and decompose their own bodies into the air and earth again. The animal burns, or undergoes the like perpetual consumption. The earth burns,- - the mountains burn and decompose, slower, but incessantly. It is almost inevitable to push the generalization up into higher parts of nature, rank over rank into sentient beings. Nations burn with internal fire of thought and affection, which wastes while it works. We shall find finer combustion and finer fuel. Intellect is a fire: rash and pitiless it melts this wonderful bone-house which is called man. Genius even, as it is the greatest good, is the greatest harm. Whilst all thus burns, - the universe in a blaze kindled from the torch of the sun,it needs a perpetual tempering, a phlegm, a sleep, atmospheres of azote, deluges of water, to check the fury of the conflagration; a hoarding to check the spending; a centripetence equal to the centrifugence; and this is invariably supplied.

The railroad dirt-cars are good excavators; but there 
is no porter like Gravitation, who will bring down any weights which man cannot carry, and if he wants aid, knows where to find his fellow-laborers. Water works in masses, and sets its irresistible shoulder to your mills or your ships, or transports vast boulders of rock in its iceberg a thousand miles. But its far greater power depends on its talent of becoming little, and entering the smallest holes and pores. By this agency, carrying in solution elements needful to every plant, the vegetable world exists.

But as I said, we must not paint the farmer in rosecolor. Whilst these grand energies have wrought for him, and made his task possible, he is habitually engaged in small economies and is taught the power that lurks in petty things. Great is the force of a few simple arrangements; for instance, the powers of a fence. On the prairie you wander a hundred miles, and hardly find a stick or a stone. At rare intervals, a thin oak opening has been spared, and every such section has been long occupied. But the farmer manages to procure wood from far, puts up a rail fence, and at once the seeds sprout and the oaks rise. It was only browsing and fire which had kept them down. Plant fruit-trees by the roadside and their fruit will never be allowed to ripen. Draw a pine fence about them and for fifty years they mature for the owner their delicate fruit. There is a great deal of enchantment in a chestnut rail or picketed pine boards.

Nature suggests every economical expedient somewhere on a great scale. Set out a pine-tree, and it dies in the first year, or lives a poor spindle. But Nature drops a pine-cone in Mariposa, and it lives fifteen cen- 
turies, grows three or four hundred feet high, and thirty in diameter,-grows in a grove of giants, like a colonnade of Thebes. Ask the tree how it was done. It did not grow on a ridge but in a basin, where it found deep soil, cold enough and dry enough for the pine; defended itself from the sun by growing in groves, and from the wind by the walls of the mountain. The roots that shot deepest, and the stems of happiest exposure, drew the nourishment from the rest, until the less thrifty perished and manured the soil for the stronger, and the mammoth Sequoias rose to their enormous proportions. The traveller who saw them remembered his orchard at home, where every year, in the destroying wind, his forlorn trees pined like suffering virtue. In September when the pears hang heaviest, and are taking from the sun their gay colors, comes usually a gusty day which shakes the whole garden, and throws down the heaviest fruit in bruised heaps. The planter took the hint of the Sequoias, built a high wall, or-better-surrounded the orchard with a nursery of birches and evergreens. Thus he had the mountain basin in miniature; and his pears grew to the size of melons, and the vines beneath them ran an eighth of a mile. But this shelter creates a new climate. The wall that keeps off the strong wind keeps off the cold wind. The high wall reflecting the heat back on the soil gives that acre a quadruple share of sunshine,

Enclosing in the garden square

A dead and standing pool of air,

and makes a little Cuba within it, whilst all without is I abrador.

The chemist comes to his aid every year by following 
out some new hint drawn from Nature, and now affirms that this dreary space occupied by the farmer is needless: he will concentrate his kitchen-garden into a box of one or two rods square, will take the roots into his laboratory; the vines and stalks and stems may go sprawling about in the fields outside, he will attend to the roots in his tub, gorge them with food that is good for them. The smaller his garden, the better he can feed it, and the larger the crop. As he nursed his Thanksgiving turkeys on bread and milk, so he will pamper his peaches and grapes on the viands they like best. If they have an appetite for potash, or salt, or iron, or ground bones, or even now and then for a dead hog, he will indulge them. They keep the secret well, and never tell on your table whence they drew their sunset complexion or their delicate flavors.

See what the farmer accomplishes by a cartload of tiles: he alters the climate by letting off water which kept the land cold through constant evaporation, and allows the warm rain to bring down into the roots the temperature of the air and of the surface-soil; and he deepens the soil, since the discharge of this standing water allows the roots of his plants to penetrate below the surface of the subsoil, and accelerates the ripening of the crop. The town of Concord is one of the oldest towns in this country, far on now in its third century. The selectmen have once in every five years perambulated the boundaries, and yet, in this very year, a large quantity of land has been discovered and added to the town without a murmur of complaint from any quarter. By drainage we went down to a subsoil we did not know, and have found there is a Concord under old Concord, 
which we are now getting the best crops from; a Middlesex under Middlesex; and, in fine, that Massachusetts has a basement story more valuable, and that promises to pay a better rent than all the superstructure. But these tiles have acquired by association a new interest. These tiles are political economists, confuters of Malthus and Ricardo; they are so many young Americans announcing a better era,-more bread. They drain the land, make it sweet and friable; have made English Chat Moss a garden, and will now do as much for the Dismal Swamp. But beyond this benefit, they are the text of better opinions and better auguries for mankind.

There has been a nightmare, bred in England, of indigestion and spleen among landlords and loomlords, namely, the dogma that men breed too fast for the powers of the soil; that men multiply in a geometrical ratio, whilst corn only in an arithmetical; and hence that, the more prosperous we are, the faster we approach these frightful limits: nay, the plight of every new generation is worse than of the foregoing, because the first comers take up the best lands; the next, the second best; and each succeeding wave of population is driven to poorer, so that the land is ever yielding less returns to enlarging hosts of eaters. Henry Carey of Philadelphia replied: "Not so, Mr. Malthus, but just the opposite of so is the fact."

The first planter, the savage, without helpers, without tools, looking chiefly to safety from his enemy,-man or beast,-takes poor land. The better lands are loaded with timber, which he cannot clear; they need drainage, which he cannot attempt. He cannot plough, or fell trees, or drain the rich swamp. He is a poor creature; 
he scratches with a sharp stick, lives in a cave or a hutch, has no road but the trail of the moose or bear; he lives on their flesh when he can kill one, on roots and fruits when he cannot. He falls, and is lame; he coughs, he has a stitch in his side, he has a fever and chills : when he is hungry, he cannot always kill and eat a bear;-chances of war,- sometimes the bear eats him. 'Tis long before he digs or plants at all, and then only a patch. Later he learns that his planting is better than hunting; that the earth works faster for him than he can work for himself,- - works for him when he is asleep, when it rains, when heat overcomes him. The sunstroke which knocks him down brings his corn up. As his family thrive, and other planters come up around him, he begins to fell trees, and clear good land; and when, by and by, there is more skill, and tools and roads, the new generations are strong enough to open the lowlands, where the wash of mountains has accumulated the best soil, which yield a hundredfold the former crops. The last lands are the best lands. It needs science and great numbers to cultivate the best lands, and in the best manner. Thus true political economy is not mean but liberal, and on the pattern of the sun and sky. Population increases in the ratio of morality; credit exists in the ratio of morality.

Meantime we cannot enumerate the incidents and agents of the farm without reverting to their influence on the farmer. He carries out this cumulative preparation of means to their last effect. This crust of soil which ages have refined he refines again for the feeding of a civil and instructed people. The great elements with which he deals cannot leave him unaffected, or 
unconscious of his ministry; but their influence somewhat resembles that which the same Nature has on the child-of subduing and silencing him. We see the farmer with pleasure and respect, when we think what powers and utilities are so meekly worn. He knows every secret of labor: he changes the face of the landscape. Put him on a new planet, and he would know where to begin; yet there is no arrogance in his bearing, but a perfect gentleness. The farmer stands well on the world. Plain in manners as in dress, he would not shine in palaces; he is absolutely unknown and inadmissible therein; living or dying, he never shall be heard of in them; yet. the drawing-room heroes put down beside him would. shrivel in his presence-he solid and unexpressive, they expressed to gold-leaf. But he stands well on the world, - as Adam did, as an Indian does, as Homer's heroes, Agamemnon or Achilles, do. He is a person whom a poet of any clime-Milton, Firdusi, or Cervantes-would appreciate as being really a piece of the old Nature, comparable to sun and moon, rainbow and flood: because he is, as all natural persons are, representatives of Nature as much as these.

That uncorrupted behavior which we admire in animals and in young children belongs to him, to the hunter, the sailor,- the man who lives in the presence of Nature. Cities force growth, and make men talkative and entertaining, but they make them artificial. What possesses interest for us is the raturel of each, his constitutional excellence. This is forever a surprise, engaging and lovely; we cannot be satiated with knowing it, and about it; and it is this which the conversation with Nature cherishes and guards. 


\section{II}

\section{THE HOLY EARTH*}

\section{Liberty H. Bailey}

\section{FIRST, THE STATEMENT}

So Bountirul hath been the earth and so securely have we drawn from it our substance, that we have taken it all for granted as if it were only a gift, and with little care or conscious thought of the consequences of our use of it; nor have we very much considered the essential relation that we bear to it as living parts in the vast creation.

It is good to think of ourselves-of this teeming, tense, and aspiring human race-as a helpful and contributing part in the plan of a cosmos, and as participators in some far-reaching destiny. The idea of responsibility is much asserted of late, but we relate it mostly to the attitude of persons in the realm of conventional conduct, which we have come to regard as very exclusively the realm of morals; and we have established certain formalities that satisfy the conscience. But there is some deeper relation than all of this, which we must recognize and the consequences of which we must practise. There is a directer and more personal obligation than that which expends itself in loyalty to the manifold organizations and social requirements of the present

* From "The Holy Earth," by permission of the author. 
day. There is a more fundamental coöperation in the scheme of things than that which deals with the proprieties or which centers about the selfishness too often expressed in the salvation of one's soul.

We can be only onlookers on that part of the cosmos that we call the far heavens, but it is possible to coöperate in the processes on the surface of the sphere. This coöperation may be conscious and definite, and also useful to the earth; that is, it may be real. What means this contact with our natural situation, this relationship to the earth to which we are born, and what signify this new exploration and conquest of the planet and these accumulating prophecies of science? Does the mothership of the earth have any real meaning to us?

All this does not imply a relation only with material and physical things, nor any effort to substitute a nature religion. Our relation with the planet must be raised into the realm of spirit; we cannot be fully useful otherwise. We must find a way to maintain the emotions in the abounding commercial civilization. There are two kinds of materials, - those of the native earth and the idols of one's hands. The latter are much in evidence in modern life, with the conquests of engineering, mechanics, architecture, and all the rest. We visualize them everywhere, and particularly in the great centers of population. The tendency is to be removed farther and farther from the everlasting backgrounds. Our religion is detached.

We come out of the earth and we have a right to the use of the materials; and there is no danger of crass materialism if we recognize the original materials as divine and if we understand our proper relation to the 
creation, for then will gross selfishness in the use of them be removed.

This will necessarily mean a better conception of property and of one's obligation in the use of it. We shall conceive of the earth, which is the common habitation, as inviolable. One does not act rightly toward one's fellows if one does not know how to act rightly toward the earth.

Nor does this close regard for the mother earth imply any loss of mysticism or of exaltation: quite the contrary. Science but increases the mystery of the unknown and enlarges the boundaries of the spiritual vision. To feel that one is a useful and coöperating part in nature is to give one kinship, and to open the mind to the great resources and the high enthusiasms.

Here arise the fundamental common relations. Here arise also the great emotions and conceptions of sublimity and grandeur, of majesty and awe, the uplift of vast desires,- when one contemplates the earth and the universe and desires to take them into the soul and to express oneself in their terms; and here also the responsible practices of life take root.

So much are we now involved in problems of human groups, so persistent are the portrayals of our social afflictions, and so well do we magnify our woes by insisting on them, so much in sheer weariness do we provide antidotes to soothe our feelings and to cause us to forget by means of many empty diversions, that we may neglect to express ourselves in simple, free, personal joy and to separate the obligation of the individual from the irresponsibilities of the mass. 


\section{IN THE BEGINNING}

It suits my purpose to quote the first sentence in the Hebrew Scripture: In the beginning God created the heaven and the earth.

This is a statement of tremendous reach, introducing the cosmos; for it sets forth in the fewest words the clemental fact that the formation of the created earth lies above and before man, and that therefore it is not man's but God's. Man finds himself upon it, with many other creatures, all parts in some system which, since it is beyond man and superior to him, is divine.

Yet the planet was not at once complete when life had appeared upon it. The whirling earth goes through many vicissitudes; the conditions on its fruitful surface are ever-changing; and the forms of life must meet the new conditions: so does the creation continue, and every day sees the genesis in process. All life contends, sometimes ferociously but more often bloodlessly and benignly, and the contention results in momentary equilibrium, one set of contestants balancing another; but every change in the outward conditions destroys the equation and a new status results. Of all the disturbing living factors, man is the greatest. He sets mighty changes going, destroying forests, upturning the slecping prairies, flooding the deserts, deflecting the courses of the rivers, building great cities. He operates consciously and increasingly with plan aforethought; and therefore he carries heavy responsibility.

This responsibility is recognized in the Hebrew Scripture, from which I have quoted; and I quote it again because I know of no other Scripture that states it so well. Man is given the image of the Creator, even when 
formed from the dust of the earth, so complete is his power and so real his dominion: And God blessed them: and God said unto them, Be fruitful, and multiply, and replenish the earth, and subdue it; and have dominion over the fish of the sea, and over the fowl of the air, and over every living thing that moveth upon the earth.

One cannot receive all these privileges without bearing the obligation to react and to partake, to keep, to cherish, and to coöperate. We have assumed that there is no obligation to an inanimate thing, as we consider the earth to be: but man should respect the conditions in which he is placed; the earth yields the living creature; man is a living creature; science constantly narrows the gulf between the animate and the inanimate, between the organized and the inorganized; evolution derives the creatures from the earth; the creation is one creation. I must accept all or reject all.

\section{THE EARTH IS GOOD}

It is good to live. We talk of death and of lifelessness, but we know only of life. Even our prophecies of death are prophecies of more life. We know no better world: whatever else there may be is of things hoped for, not of things seen. The objects are here, not hidden nor far to seek: And God saw everything that He had made, and, behold, it was very good.

These good things are the present things and the living things. The account is silent on the things that were not created, the chaos, the darkness, the abyss. Plato, in the "Republic," reasoned that the works of the Creator must be good because the Creator is good. This goodness is in the essence of things; and we sadly need 
to make it a part in our philosophy of life. The earth is the scene of our life, and probably the very sourcc of it. The heaven, so far as human beings know, is the source only of death; in fact, we have peopled it with the dead. We have built our philosophy on the dead.

We seem to have overlooked the goodness of the earth in the establishing of our affairs, and even in our philosophies. It is reserved as a theme for preachers and for poets. And yet, the goodness of the planet is the basic fact in our existence.

I am not speaking of good in an abstract way, in the sense in which some of us suppose the Creator to have expressed Himself as pleased or satisfied with His work. The earth is good in itself, and its products are good in themselves. The earth sustains all things. It satisfies. It matters not whether this satisfaction is the result of adaptation in the process of evolution; the fact remains that the creation is good.

To the common man the earth propounds no system of philosophy or of theology. The man makes his own personal contact, deals with the facts as they are or as he conceives them to be, and is not swept into any system. He has no right to assume a bad or evil earth, although it is difficult to cast off the hindrance of centuries of teaching. When he is properly educated he will get a new resource from his relationships.

It may be difficult to demonstrate this goodness. In the nature of things we must assume it, although we know that we could not subsist on a sphere of the opposite qualities. The important consideration is that we appreciate it, and this not in any sentimental and im- 
personal way. To every bird the air is good; and a man knows it is good if he is worth being a man. To every fish the water is good. To every beast its food is good, and its time of sleep is good. The creatures experience that life is good. Every man in his heart knows that there is goodness and wholeness in the rain, in the wind, the soil, the sea, the glory of sunrise, in the trees, and in the sustenance that we derive from the planet. When we grasp the significance of this situation, we shall forever supplant the religion of fear with a religion of consent.

We are so accustomed to these essentials - to the rain, the wind, the soil, the sea, the sunrise, the trees, the sustenance-that we may not include them in the categories of the good things, and we endeavor to satisfy ourselves with many small and trivial and exotic gratifications; and when these gratifications fail or pall, we find ourselves helpless and resourceless. The joy of sound sleep, the relish of a sufficient meal of plain and wholesome food, the desire to do a good day's work and the recompense when at night we are tired from the doing of it, the exhilaration of fresh air, the exercise of the natural powers, the mastery of a situation or a problem-these and many others like them are fundamental satisfactions, beyond all pampering and all toys, and they are of the essence of goodness. I think we should teach all children how good are the common necessities, and how very good are the things that are made in the beginning.

\section{IT IS KINDIY}

We hear much about man being at the mercy of nature, and the literalist will contend that there can be no holy 
relation under such conditions. But so is man at the mercy of God.

It is a blasphemous practice that speaks of the hostility of the earth, as if the earth were full of menaces and cataclysms. The old fear of nature, that peopled the earth and sky with imps and demons, and that gave a future state to Satan, yet possesses the minds of men, only that we may have ceased to personify and to demonize our fears, although we still persistently contrast what we call the evil and the good. Still do we attempt to propitiate and appease the adversaries. Still do we carry the ban of the early philosophy that assumed materials and "the flesh" to be evil, and that found a way of escape only in renunciation and asceticism.

Nature cannot be antagonistic to man, secing that man is a product of nature. We should find vast joy in the fellowship, something like the joy of Pan. We should feel the relief when we no longer apologize for the Creator because of the things that are made.

It is true that there are devastations of flood and fire and frost, scourge of disease, and appalling convulsions of earthquake and eruption. But man prospers; and we know that the catastrophes are greatly fewer than the accepted bounties. We have no choice but to abide.

No growth comes from hostility. It would undoubtedly be a poor human race if all the pathway had been plain and easy.

The contest with nature is wholcsome, particularly when pursued in sympathy and for mastery. It is worthy a being created in God's image. The earth is perhaps a stern earth, but it is a kindly earth. 
Most of our difficulty with the earth lies in the effort to do what perhaps ought not to be done. Not even all the land is fit to be farmed. A good part of agriculture is to learn how to adapt one's work to nature, to fit the crop-scheme to the climate and to the soil and the facilities. To live in right relation with his natural conditions is one of the first lessons that a wise farmer or any other wise man learns. We are at pains to stress the importance of conduct; very well: conduct toward the earth is an essential part of it.

Nor need we be afraid of any fact that makes one fact more or less in the sum of contracts between the earth and the earth-born children. All "higher criticism" adds to the faith rather than subtracts from it, and strengthens the bond between. The earth and its products are very real.

Our outlook has been drawn very largely from the abstract. Not being yet prepared to understand the conditions of nature, man considered the earth to be inhospitable, and he looked to the supernatural for relief; and relief was heaven. Our pictures of heaven are of the opposites of daily experience- of release, of peace, of joy uninterrupted. The hunting-grounds are happy and the satisfaction has no end. The habit of thought has been set by this conception, and it colors our dealings with the human questions and to much extent it controls our practice.

But we begin to understand that the best dealing with problems on earth is to found it on the facts of earth.

This is the contribution of natural science, however abstract, to human welfare. Heaven is to be a real con- 
sequence of life on earth; and we do not lessen the hope of heaven by increasing our affection for the earth, but rather do we strengthen it. Men now forget the old images of heaven, that they are mere sojourners and wanderers lingering for deliverance, pilgrims in a strange land. Waiting for this rescue, with posture and formula and phrase, we have overlooked the essential goodness and quickness of the earth and the immanence of God.

This feeling that we are pilgrims in a vale of tears has been enhanced by the widespread belief in the sudden ending of the world, by collision or some other impending disaster, and in the common apprehension of doom; and lately by speculations as to the aridation and death of the planet, to which all of us have given more or less credence. But most of these notions are now considered to be fantastic, and we are increasingly confident that the earth is not growing old in a human sense, that its atmosphere and its water are held by the attraction of its mass, and that the sphere is at all events so permanent as to make little difference in our philosophy and no difference in our good behavior.

I am again impressed with the first record in Genesis in which some mighty prophet-poct began his account with the creation of the physical universe.

So do we forget the old-time importance given to mere personal salvation, which was permission to live in heaven, and we think more of our present situation, which is the situation of obligation and of service; and he who loses his life shall save it.

We begin to foresee the vast religion of a better social order. 


\section{THE EARTH IS HOLY}

Verily, then, the earth is divine, because man did not make it. We are here, part in the creation. We cannot escape. We are under obligation to take part and to do our best, living with each other and with all the creatures. We may not know the full plan, but that does not alter the relation. When once we set ourselves to the pleasure of our dominion, reverently and hopefully, and assume all its responsibilities, we shall have a new hold on life.

We shall put our dominion into the realm of morals. It is now in the realm of trade. This will be very personal morals, but it will also be national and racial morals. More iniquity follows the improper and greedy division of the resources and privileges of the earth than any other form of sinfulness.

If God created the earth, so is the earth hallowed; and if it is hallowed, so must we deal with it devotedly and with care that we do not despoil it, and mindful of our relations to all beings that live on it. We are to consider it religiously: Put off thy shoes from off thy feet, for the place whereon thou standest is holy ground.

The sacredness to us of the earth is intrinsic and inherent. It lies in our necessary relationship and in the duty imposed upon us to have dominion, and to exercise ourselves even against our own interests. We may not waste that which is not ours. To live in sincere relations with the company of created things and with conscious regard for the support of all men now and yet to come, must be of the essence of righteousness.

This is a larger and more original relation than the 
modern attitude of appreciation and admiration of nature. In the days of the patriarchs and prophets, nature and man shared in the condemnation and likewise in the redemption. The ground was cursed for Adam's sin. Paul wrote that the whole creation groaneth and travaileth in pain, and that it waiteth for the revealing. Isaiah proclaimed the redemption of the wilderness and the solitary place with the redemption of man, when they shall rejoice and blossom as the rose, and when the glowing sand shall become a pool and the thirsty ground springs of water.

The usual objects have their moral significance. An oak tree is to us a moral object because it lives its life regularly and fulfils its destiny. In the wind and in the stars, in forest and by the shore, there is spiritual refreshment: And the spirit of God moved upon the face of the waters.

I do not mean all this, for our modern world, in any vague or abstract way. If the earth is holy, then the things that grow out of the earth are also holy. They do not belong to man to do with them as he will. Dominion does not carry personal ownership. There are many generations of folk yet to come after us, who will have equal right with us to the products of the globe. It would seem that a divine obligation rests on every soul. Are we to make righteous use of the vast accumulation of knowledge of the planet? If so, we must have a new formulation. The partition of the earth among the millions who live on it is necessarily a question of morals; and a society that is founded on an unmoral partition and use cannot itself be righteous and whole. 


\section{III \\ THE LOVE OF NATURE *}

\section{Mrs. Schuyler Van Rensselaer}

Alu human beings draw pleasure from Nature in an instinctive way. They enjoy fresh air, sunshine, and open outlooks; they prefer a blue sky to a gray one, and will confess that a green landscape is pleasanter to the eye than grimy pavements, even though for other reasons they may prefer to live in town.

Such likings as these prove no love of Nature; they are almost purely physical; sentiment has little more to do with them than with the pleasure of an animal basking in the sun. But the majority of people, even among the uncultivated classes, have a deeper feeling for Nature than this, and appreciate something of its beauty. Stupid and brutalized indeed is the man or woman who does not notice a brilliant bed of flowers, or would not be impressed by the sight of a great mountain-chain. On Sundays our parks are crowded with very poor people who spread through every quiet walk and shadowy glade, and like nothing so well as to lie or saunter on the grass; and although much of their pleasure is simply physical, anyone who has sympathetically mingled with them knows that part of it is of finer quality. The beauty of the landscape speaks to even the dullest eye, and appeals through it to the most

*From "Art Out of Doors," by Mrs. Schuyler Van Rensselaer. Copyright, 1893, by Charles Scribner's Sons. By permission of the publishers. 
sluggish imagination. The roughest cockney admires the beauty of the shores of the Hudson when he sees them on some summer excursion, and is impressed by the splendor of the sea when for the first time he stands on a shore where its waves are breaking.

This instinctive admiration for the charms of the natural world is what many people understand by the love of Nature. But it is not, in any true sense, the love of Nature. It is merely a love for natural things which are beautiful, of course, but which are also unfamiliar and therefore striking. Let the dweller in tenementhouses inhabit a lodge in Central Park for a while, and he would probably seek his Sunday entertainment in a down-town street. Let him work on a North River schooner, and he would quickly forget to notice the beauty of the shores.

And this same attitude toward Nature may be observed in persons of much wider cultivation. To them also familiar natural things soon grow uninteresting. The artisans who crowd our Park on Sunday enjoy its beauty more than do most of the wealthicr folk who drive there every day. It is curious to notice how few of these ever seem to look at anything but the people in the other carriages, and how seldom they turn from the fashionable East Drive into the much more beautiful West Drive. And it is still more curious to find that scores of them who have made pilgrimages in search of natural beauty from the Nile to the Sierras and from the St. Lawrence to Mexico, have never left their carriages to see what the pathways in their own park might reveal. The Ramble is as unknown to them as though it lay in China, and they exclaim in surprise 
if you tell them they might travel a thousand miles and see nothing prettier.

People of this kind, I say, do not care about Nature; at most they care for those conspicuous natural effects which they call scenery. Scenery is not the whole of natural beauty; it is only one manifestation of it; and a person who delights in a magnificent view but finds all flat regions hopelessly tiresome, or who feels the grandeur of a rocky coast but not the loveliness of a green-fringed, quiet shore, is in a rudimentary stage of development. His attitude is like that of one who should profess to love flowers but, while admiring a rose, should despise a forget-me-not. The true lover of Nature is he who gives interested attention to all natural effects and forms, and finds much beauty where the average eye finds none.

Of course there are grades and degrees of natural beauty, and for each the true lover will have a corresponding degree of admiration. He will not call a Belgian plain as beautiful as the valley of the Rhone, or declare that a nettle has the charm of a branch of appleblossoms. But there are few plants which have no beauty of any kind; and there are few earthly spots, where man's hand has not obliterated Nature's intentions, so devoid of attraction that the sensitive eye and mind cannot enjoy them keenly.

Admiration, says a French writer on art, "is the active, rsthetic form of curiosity." And this means that he who really admires the works of God will be lovingly curious about the hyssop on the wall as well as about the cedar of Lebanon, and will see more to please him in a rough bit of pasture-land than the average 
person sees in a whole fertile valley. Who can love Nature better than the landscape-painter, spending his whole life in the effort to transfer her features to his canvas? But no one is less in need than the landscapepainter of what is called scenery. It is not he who greatly prefers the cañon of the Yellowstone to the banks of the little river near at hand. When he is brought face to face with scenic grandeurs he appreciates them more keenly than anyone else, but he gladly comes back to his quiet plains, his placid pools, his little forest glades. Nor is it merely because these things are better fitted for painting than grander things. Any little corner of the world is enough for him, as a thing to enjoy no less than as a thing to paint. Delacroix was not a landscape-painter, so we cannot suspect him of professional bias; and there has never been a painter whom we could more easily credit with an inborn love for striking and even spectacular kinds of beauty. But fine scenery was not essential to his enjoyment of Nature. "The poorest little alley," he wrote one day from a shabby suburb of Paris, "with its straight little leafless saplings, in a dull and flat horizon, can say as much to the imagination as the most bepraised of sites. This tiny cotyledon piercing the earth, this violet shedding its first whiff of perfume, are enchanting. I love such things as much as the pines of Italy."

This is the voice of the true lover of Nature, and like it was Corot's voice, constantly praising, not the grandeurs which he had seen on his travels, but the tender, gentle subtile beauties around his home at Ville d'Avray, and more than anything else, the humblest of them all-"my leaves and my little birds." If one is 
born to love Nature as those men did and all true artists do, or if he ever learns the beneficent lesson, the quietest scenes will impress him, the most familiar will be ever new. The shadow of a blackberry-vine, as it trails over a gray rock, will give him as delightful an emotion as the sight of a great mountain; and custom will not stale his pleasure, for it will be as infinitely varied, as perpetually renewed, as the leaves on the trees, the blades of grass in the fields, the tints in the sunset skies.

People who run about, summer after summer, in search of new landscapes to admire, will often tell you that it is because they love Nature. But if they did they would be much less apt to run about; they could exercise their passion within narrower limits, and they would be likely to content themselves within such limits because a particular love for particular beauties would result from long acquaintance with them.

In Mrs. Robbin's "Rescue of an Old Old Place," she rightly says that one of the great benefits which spring from the possession of a bit of country soil is the development of the love of home, the suppression of that restless desire for change which makes of so many Americans "possible tramps" instead of established citizens. But a genuine love for Nature may serve a person pretty well in place of the actual ownership of land; for in whatever corner of the country he may chance to live, he will see, understand, and appreciate every part and phase of its beauty, and thus, in a sense, feel himself the owner of the whole region; and the oftener he visits it, the stronger and more intimate will become his attachment, his feeling of possession. Of course he will 
not be without a keen desire to see as much of the big world as possible, and to learn how many kinds of beauty it can show. But this desire will not be the imperious need for "a change" which is felt by less fortunate souls; and often it will be so much weaker than his wish to stay among the things which he knows best that year after year will pass and foreign lands, or even neighboring country-sides, will tempt in vain while he watches new clouds blow over his familiar hills, new flowers spring up in his familiar woods, and every longloved shrub and tree assume new aspects with each season's growth and alterations. The changes which Nature brings every moment before his eyes will satiate his desire for novelty.

This is the true secret of every kind of love: if a thing really appeals to us, the better we know it the more we care about it. The true lover of Nature loves her as he loves mankind. He has his favorite corners of the world as he has his friends, and does not constantly wish to exchange them for others, or perpetually contrast their attractions with the attractions of others. If everyone admires them his joy in them is increased; but if he is almost alone in his appreciation, this fact is in itself the source of a special kind of pleasure and pride. He seeks for novelty and freshness in Nature as he likes to make acquaintance with interesting strangers, but comes back as gladly to the familiar scene as to the familiar face. The tree which he has watched as it grew from a sapling to fine maturity delights him even more than a finer tree about which no memories or hopes are clustered, for even if he has not planted and watered it himself, even if it grows in the 
neighboring forest instead of his own field, he loves it with a personal, proprietary affection. When he drives through a beautiful new country his eyes are perpetually charmed; but when he drives through the roads around his home his heart is touched and his imagination is stirred by the beauty of past years as well as by the beauty of to-day, and by the hope that next year's beauty also may belong to him. Each tree is a friend, each bush has a special message for his special ear, each flower is greeted as the child of other flowers which he knew last summer in the same corner of the roadside. He not only admires what he sees-he is interested by everything he sees in a sense that is impossible where things are beheld for the first time. And true love, if it means admiration, means interest also, whether inanimate things or human beings are in question.

Therefore, one who truly loves Nature does not need what are commonly called fine views; he needs no great ranges of mountains, picturesque stretches of rocky coast, or outlooks over wide expanses of valley, hill, and river. Every view not seriously marred by some incongruous work of man has its charm for his eyes. And he recognizes, moreover, that a very fine view must often be bought at the expense of other beauties. If, for instance, there are mountains around him, he cannot have that far, low horizon-line which, stretching its mighty curve at a seemingly immeasurable distance, gives an unequalled sense of space, freedom, and infinity. "I have never seen the sky before," a painter once exclaimed who had passed his life in hilly regions and now for the first time stood in the flat, quiet country near Cape Cod; "I did not know that it was so vast, or so 
near, or so round, or that there were so many stars, or that a sight of them all could be so magnificent. I never before watched the moon come up from below the earth instead of merely from behind the hills; and I never saw the whole of a sunset until I came here." And he seemed to think that the panorama of the morning and evening and midnight heavens was as admirable as any terrestrial panorama which could be unrolled.

Again, in our crude and often maltreated land, grandeur in the distance often means a forlorn raggedness in the foregrounds, and a sensitive eye thinks the foreground of a picture as important as its background. Where forests have ruthlessly been cut away, and where there is not a rich soil to encourage neat and careful methods of cultivation, primeval beauty has largely vanished and the beauty of civilization has not taken its place. The true lover of Nature will feel this painfully, and all the magnificence of the mountains beyond may not compensate him for the lack of that harmonious repose in general effect which comes when all parts of a picture are in keeping.

I do not say that the true lover of Nature cares nothing for grand scenery-only that he does not actually need it. Great things impress him, but small ones content him, and he gathers pleasure from the roadside grass as well as from the giant oak or the $s \mathrm{ky}$ line of a rugged mountain-range. There is a beauty of the lily and a beauty of the pine, a beauty of the mountain and a beauty of the plain, a beauty of wide outlooks, of stately, high-walled amphitheaters, and of gentle, sequestered corners. One kind necessarily excludes the other kinds; but that does not matter if each 
arrests the eye, interests the mind, and appeals to the imagination and the heart.

Everyone realizes that more kinds of art appeal to the connoisseur than to the ordinary observer, and that, he does not exalt showy, spectacular kinds above all others. All the greatest artists in the world did not paint palace-ceilings or big altar-pictures; some of the world's most famous masterpieces measure only a couple of spans and do not show a single note of vivid color. And so it is with Nature and her masterpieces. The finest composition wrought with mountain peaks and deep ravines is not more beautiful or wonderful than one which can be wrought with a gray boulder, a pine-tree, and a carpet of moss or fern; the most splendid panoramic background is not more enchanting than may be a foreground of flowery meadow, with a middle distance of woodland, and no background at all except the luminous sky.

Of course some people are born with a deep and true love for Nature, but even in them I think this love does not show itself very early in life. In the majority of cases it seems to have been gradually developed rather than spontaneously felt. And, while no one not born with a poet's soul can ever learn to feel Nature's charms as a Corot or a Wordsworth did, anyone can learn to see them pretty clearly unless his mind is hopelessly sluggish, desperately prosaic.

How can such knowledge be acquired? One way, as I have said in speaking of trees, is to study the fine landscape-pictures. Another is the landscape-painter's own way. The practice of painting, even in the most untrained, amateurish fashion, may be an excellent help 
toward the development of a love for Nature. If an intelligent young girl would spend an hour a day, during a single summer, faithfully trying to set down in paint what she sees in Nature-now a flower or a tree, now a bit of sunset-sky, a corner of a hedge-row, or a little stretch of river-bank-she would find at the end of the season that she had gained new eyes. She would see a thousand things she had never seen before, find beauty in many that before had seemed ugly, and realize the difference between merely "liking" Nature and truly appreciating it. It would not matter if all her studies were failures and were torn up in disgust as fast as they were finished. She would have attained a great end, achieved a real success; for she would have enlarged her own powers of enjoyment to the sweetening and dignifying of all the rest of her life. Much amateur sketching is done in this country every summer, but I fear it is not often done in this spirit. The aim is to produce pretty pictures, not to cultivate the painter's own intelligence. And while the aim generally remains unattained, intelligence is scarcely increased; for, as the prettiness of the sketch has been the ruling motive, a subject has most often been chosen because it was easy to do, not because it was particularly interesting in itself, and it has been superficially looked at, not lovingly studied. 


\section{IV \\ CIVIC ART *}

\section{Frank A. WaUgh}

BIG issues are stirring in the rural districts of America. The farming communities, and the small towns dependent on them, have reached a stage of genuine and confident prosperity. It is no longer a question with them whether they can live through the winter and pay the interest on the mortgage. The main problem is not now how to make more money, but how to live more comfortably. The way the farmers spend money for automobiles proves this.

Better homes and better home surroundings are the matters of prime concern. Better schools, better playgrounds, better churches, better libraries, better roads, are wanted-better cemeteries, even. In the main, these are community problems, to be solved by the coöperative action of the whole neighborhood. Coöperation has been talked of as the coming remedy for all the farmer's difficulties; but the word has been given too narrow a meaning and application. The neighborhood can accomplish more by coöperating to own a grange hall, or the boys can do better coöperating to maintain a baseball league, than the farmers can coöperating to buy fertilizer twenty-five cents under market price. And the best place to learn how to coöperate is in the care of

* From "Rural Improvement," by permission of the author and of the publishers, the Orange Judd Company. 
public property, such as parks, commons, playgrounds, schools, and roads which we own in common.

The country needs to be improved. Some of us who live in the country and love it hate to admit this. But the steady stream of young folks-and some older ones - moving toward the city shows that most people still find the city more attractive than the country. Look what has been done for the city! Fine schools, theaters, picture shows, playgrounds, parks, music, boulevardsplay, beauty, and entertainment. The simple fact is that the country must do something to off set these attractions or the exodus of live young men and women will go on forever.

Better farming-bigger crops and better prices-will do something. Better houses and household equipment will do more. Better neighborhood equipment for recreation and wholesome social intercourse will do still more. There must be improvement all along the line. This is the Rural Improvement which I would preach.

At the same time I would point out that any improvement of this sort can best begin on its physical side. The concrete problems of physical property are easier to grasp; and if it is true, as it partly is, that a man must have a sound body in order to support a vigorous mind and a healthy conscience, it is more truly true that a community must be clean and orderly physically in order to be clean and orderly socially and morally. One of the strongest elements in general agricultural improvement is to be found in the contribution offered by civic art-the art which builds a sound physical frame for the support of a healthy community life.

Art in general has no very high reputation in Amer- 
ica. It is thought to be not sufficiently "practical." Yet at present this mistaken view is giving way to a better understanding. In the first place people are beginning to see that anything is none the less useful for being beautiful. A beautiful bridge will carry just as big a load as an ugly one. A beautiful and dignified house is just as comfortable as a wretched plain one. A well-proportioned silo will keep the silage just as sweet as an ugly unpainted one with the top off. Beauty does not interfere with utility, nor utility with beauty. The two are sisters. They should walk hand in hand. Nothing can be truly beautiful unless it is perfectly suited to its proper use; and, conversely, nothing can perfectly serve its highest uses unless it is beautiful.

Thus we are awakening in this country (to put the whole meaning into one phrase) to the necessity of having things done right. A barn is not strictly right until it serves its native purposes to the fullest possible measure-and when this full and high and overflowing stage of utility is reached, the barn must be also beautiful.

Now in public affairs (which we may call also civic affairs or community affairs) we reach this conclusion a trifle later. We sooner see that our own houses and silos must be right than we realize that the public schoolhouses, roads, and cemeteries come under the same high necessity. But this second stage has been fully reached in many American communities, and the need is keenly felt of realizing in all public works the highest utility combined with the utmost beauty. And this conclusion may almost be adopted as the definition of art-to realize the maximum of utility combined with the maxi- 
mum of beauty. When thus rightly understood, art becomes an indispensable factor in daily life-whether private or public life - and not a mere superfluity fit for the attention only of dudes, decadents, and highbrows.

Civic art, therefore, may be defined as the practice of doing things right with reference to all public worksor to state it more explicitly, it is the constant endeavor to secure in all public works the maximum of utility combined with the maximum of beauty.

Civic art thus becomes a branch of landscape architecture, which endeavors to secure for all the outdoor needs of humanity the greatest convenience plus the utmost order and beauty. The principles of civic art, then, are the same as those of landscape architecture, and this great art must be chiefly appealed to to supply both the principles and the detailed practices for application in the newer branch of civic art.

It would lead us too far afield from our present studies should we attempt here to elucidate all the basic principles of landscape architecture and to apply them to the subject in hand. We may only say that here the great principles of order, which are the principles of design, rule supreme. To have everything done in perfect order - to have everything kept in perfect orderthis is the keynote of civic art.

Civic art strives to secure this perfect good orderthis maximum of utility plus a maximum of beauty-in the things which belong to the community. These public possessions are streets, commons, parks, playgrounds, school buildings, churches, libraries, town halls, court houses, and scenery, with various other important items. Unfortunately the sense, and even the knowledge, of 
common public ownership in such things is still very weak in America. For too many years we have laid every stress on the private ownership of our own individual property. All laws have been made to protect individuals in this personal right. All preaching has aimed to quicken conscience with reference to the rights of others. And so we have almost forgotten that most of the greatest gifts in the world belong to nobodythat is, to everybody - that is, to us all. The air and the blue sky still belong to us anyway. The sweet water that falls from heaven belongs to us, too, except that many of us have chosen to live in cities and to pay someone to bring us our share of it. Then the schools are not mine nor yours, but ours; and the roads belong to no man, though the automobile hog may act as though they did; and the churches are the property of all, though Protestant sectarianism has indirectly inculcated the belief that one or two men own each church; and the cemeteries are public property where we are all at last "free and equal" in spite of the Declaration of Independence.

And so all of us, acting together, strive to secure the best results obtainable in the development of our common property, to secure the very highest utility, to enjoy the greatest possible beauty, and to maintain everything in the best possible order. This is civic art.

In the cities, civic art has been developed first. There are sufficient reasons for that fact. But the country, equally with the city, has public property, and should have more, and this property needs to be developed to its highest utility and to be equipped with every available beauty. Unfortunately again the sense of common 
ownership is weaker in the country than in the city, and harder to arouse. Practical coöperation is harder to secure. Greater efforts are necessary, therefore, to get community improvements under way in the country.

Another difficulty lies in the fact that communities have not such definite geographic limits in the rural districts as in the cities. An incorporated city has very precise boundaries. Any individual family resides in one city and not in two. (Families with residences in New York, Newport, Palm Beach, and Reno do not count for anything in any connection.) In the country, however, every farm is the center of a neighborhood. These neighborhoods overlap and overlap again, never coming to an end except at the ocean or the impassable nountain. Practically this is the very difficult situation throughout the Central and Western states. In the New England states the town unit is so well developed politically that it makes a very convenient basis for all kinds of community action. A political club, a farmers' club, or a civic improvement society may easily be organized for any given town. Everyone in the town will accept his natural allegiance with such a society and work with it to the best of his ability.

In the Central and Western states the county is the political unit. But the county is too big for the most effective work in civic betterment. Certain enterprises, to be sure, can be undertaken on a county-wide scale, and should then be under the direction of county societies. In those states where county patriotism has substantial growth every effort should be made to put it to good use. County improvement societies may be formed, on whose programs would appear such projects as (a) 
better county roads, (b) better county buildings, (c) county high schools and agricultural schools, (d) scenic and historic reservations.

But smaller units of organization must be found, even in most enterprising counties. Village improvement societies can take care of the small towns, and civic clubs or boards of trade or women's clubs of the larger ones. The country districts must not be forgotten, but should be divided up amongst the granges and amongst the local farmers' clubs (most of which are still to be organized).

We have spoken of the county unit, the town unit, the village unit, and the very indefinite country-neighborhood unit. Before dropping this subject we must have a look at the state unit. As a matter of fact there are many civic enterprises of state-wide scope, such as state roads, state parks, etc. Let it be distinctly understood that some of the finest civic accomplishments of the last decade have been in this field, and we may reasonably hope for more in the next decade. We have a sort of reason for this in the significant fact that the civic feeling is stronger within state boundaries than anywhere else in America. A Kansan is more proud of Kansas than of all the other stars on the flag: and a Mississippian will do more for his state than for any other geographical unit, big or little, in the universe; and a New Yorker always thinks that North America revolves round the Empire State. Inasmuch as patriotism and civic pride are pretty much one and the 'same thing, and as this civic pride is the ultimate foundation of all civic improvement, we may properly expect best results where local patriotism is strongest, and may 
thus hope to accomplish some of the biggest and best things through state-wide movements.

The time is now fully ripe for the organization of state campaigns in all states where a fair stage of social and economic development (i.e., a reasonably well organized civilization) has been attained. Such enterprises promise to be most effective if initiated and directed by the state agricultural college. A strong, aggressive, modern agricultural college can easily put into the field a small corps of experts who will assist the local communities in all the undertakings of civic betterment. These experts, carrying this civic betterment propaganda throughout the state, would deal directly with such problems as these: (a) Good roads, location, construction, and maintenance, (b) roadside and strect planting, and care of roadside trees, (c) acquisition, planning, and management of public reservations, parks, picnic grounds, commons, and playgrounds, (d) location and design of school grounds, especially country schools and those providing school gardens, experimental grounds, etc., (e) location and design and care of public cemeteries, ( $f$ ) care of country churches and church grounds, (g) location and design of all public buildings, more especially those outside of cities, (h) design and care of farm yards and village yards, (i) design, service, and sanitation of farm buildings. In every one of these lines improvement is possible and desirable. Improvement in greater or less degree can be secured by putting before the people, systematically and urgently, the best modern ideas on these several subjects. No better line of work for rural betterment can possibly be undertaken by the exten- 
sion services now organized in many agricultural colleges, or by any other organizations having in view the improvement of country life conditions.

All these civic improvement enterprises always look very formidable to the inexperienced person. Talk about town planning, country planning, or a general state plan sounds altogether futile in such ears. What can be done after all to change the plan of a town already in existence? However, the works of civic improvement are, in fact, much easier to accomplish than the public ever believes. For the greatest part civic art undertakes only to do in the right way instead. of in the wrong way things which have to be done one way or the other. Now, most people, even town and county officials, would rather do things right than to do them wrong. As the right way is usually the cheapest way, especially in the long run, there is in this fact another strong preference for the best things, whenever the public can be helped to see what plans are actually cheapest and best. The important point is to see that the public has a fair chance to know what is best. In an enormous number of cases public questions are decided without this knowledge.

In an experience in civic work covering several years I have often been surprised at the readiness, even avidity, with which apparently radical suggestions are sometimes accepted. I once asked an audience in a country town if they owned any public picnic ground. No, they said. Had they any places in town attractive enough for such uses? Oh yes, plenty of them! And then, after the lecture, and before we left the room, three men said they would personally give the land to 
the town. Dozens of similar instances could be related illustrating the ease with which the most substantial improvements are speedily and easily realized when the right idea is favorably presented.

In other cases more time is needed. Indeed, the time element is of supreme importance in most projects for public works. It requires time for any new idea to "soak in." When a new improvement is proposed it should be put fairly, fully, and clearly before the public, and kept there. Let it be a plan for a new road or a ball field, if a well-studied plan can be widely circulated and properly explained, and then if the drawings and data can be put up in plain view in the post office or other public place, and kept there, perhaps for several years, the work will eventually be carried out. It will almost do itself. The people become accustomed to the idea, they accept it as a probable result, and when the proper moment arrives they will assist in its final realization. Patience, prudence, and preparation are the watchwords of civic improvement.

One more point of fundamental importance must be borne in mind. Although civic art deals only with the physical features of the community equipment (that is, with public property of one sort or another), these physical elements do not exist by themselves and certainly not for themselves. Industrial, social, educational, religious, and other factors are present and powerful in the community life, and it is, indeed, for these things that the physical equipment is used. Now civic art in any form-village improvement, rural improvement, or state improvement campaign-cannot go very far by itself. Improvement of the streets 
depends partly on improvement of local politics, and this in turn on better schools, and all together on better churches and a growing spirit of honesty and public service. Furthermore, agricultural and industrial conditions must be improved in order that farms and factories may yield larger returns for the support of churches, schools, playgrounds, roads, and even cemeteries. All community advancement must be gained by coördinated advance all along the line. Improvement of roads and public grounds must be accompanied by improvement in schools, by reform in politics, and by genuine religious revivals. In like manner a wild religious upheaval without better streets is a waste of breath, or political reform without better schools is a delusion, or more scientific agriculture without more picnics and better churches and happier households is only vanity and vexation of spirit.

The great advantages of civic art are two: First, it deals with concrete problems and materials: that is, with property; and humanity, especially American humanity, has a most ineradicable belief in property. Civic art, therefore, supplies the basis on which communities most quickly rally, and on which a genuine coöperation can be most easily and effectively established. Secondly, civic improvement thereby becomes the indispensable training school for all higher forms of neighborly coöperation, such as deal with political, educational, and religious reforms. In a double sense civic art is the unique foundation on which to build every kind of civic improvement. 


\section{V \\ THE ART OF GARDENING * \\ Mrs. Schuyler Van Rensselaer}

The Arts of Design are usually named as three: architecture, sculpture, and painting. It is the popular belief that a man who practises one of these is an artist, and that other men who work with forms and colors are at the best but artisans. Yet there is a fourth Art of Design which well deserves to rank with them, for it demands quite as much in the way of esthetic feeling, creative power, and executive skill. This is the art which creates beautiful compositions upon the surface of the ground.

The mere statement of its purpose should show that it is truly an art. The effort to produce organic beauty is what makes a man an artist; neither the production of a merely useful organism nor of a beautiful isolated detail can suffice; he must compose a beautiful whole with a number of related parts. Therefore, while he who raises useful crops is an agriculturalist, and he who grows plants for their individual charms is a horticulturalist, and he who constructs solid roads is an engineer, the man who uses ground and plants, roads and paths, and water and accessory buildings, with an eye to organic beauty of effect, is-or ought to be-an artist.

*From "Art Out of Doors," by Mrs. Schuyler Van Rensselaer. Copyright, 1893, by Charles Scribner's Sons. By permission of the publishers. 
All the Arts of Design are thus akin in general character and purpose. But they differ from each other in many ways, and in studying the peculiarities of gardening art we find some reasons why its affinity with its sisters is so commonly ignored.

One difference is that it uses the same materials as Nature herself. In what is called the "naturalistic" style of gardening it uses them to produce many effects which, under favoring conditions, Nature might have produced without man's aid. Then, the better the result, the less likely it is to be recognized as an artificial, an artistic, result; the more perfectly the artist attains his end, the more likely we are to forget that he has been at work.

I dare say that there are many persons who do not know that a large portion of Central Park was created by Mr. Olmsted and his associates, in almost as literal a sense as any painter ever created a pictured landscape; who do not remember the dismal, barren, trecless, half-rocky, and half-swampy waste which, less than forty years ago, occupied all the tracts below the reservoir; who fancy that Nature made them beautiful with meadows, ponds, trees, and shrubs, with woodland passages, and verdurous cliffs and hollows; who think that all man has done has been to lay out the roads and paths, and build the terraces, bridges, and shelters. If they will read any contemporary description of the quondam aspect of these tracts, now so natural-looking in their beauty, and will then study the Park to-day and consider what difficulties must have attended the process which made it lovely to the eyes and convenient for the feet and wheels of crowd- 
ing thousands, they may gain some idea of what landscape-gardening means; they may understand why we who have studied it even from the outside rank it quite as high as any other art.

In naturalistic work such as this, I say, we may carelessly admire the result while forgetting that an artist wrought it. But, on the other hand, when an artist has essayed the formal, "architectural" style of gardening, and has disposed Nature's materials in frankly nonnatural ways, his activity will be recognized, but, in our country at least, few will stop to consider whether it has been artistic or not. A more or less intelligent love for natural beauty is very common with us while good judgment in art is very rare. Therefore-especially as we are unaccustomed to thinking of art outof-doors at all-we do not understand that in certain situations a formal design may be the best. Seeing that it is not Nature's work, or like Nature's work, we condemn it as a wilful misuse of good natural material. We recognize man's product, but we do not appreciate any beauty that it may possess.

Again, gardening-art differs from all others in the unstable character of its results. When surfaces are modelled and plants arranged, Nature and the artist must still work a long time together before the truc picture appears; and when once it has revealed itself, day-to-day attention will be forever needed to preserve it from the altering effects of time. It is easy to imagine, therefore, how often neglect or interference must work havoc with the best intentions, how often the passage of years must destroy or travesty the best results. 
Still another thing which prevents popular recognition of this art is our lack of clearly understood terms with which to speak about it. "Gardens" once meant pleasure-grounds of every kind, and "gardener" then had an adequately artistic sound. But as the meaning of the first term was gradually specialized, so the other gradually came to denote a mere grower of plants. "Landscape-gardener" was a title invented by the artists of the eighteenth century to mark the new tendency which they represented-the search for "natural" as opposed to "formal" beauty; and it seemed to them to need an apology as savoring, perhaps, of grandiloquence or conceit. But as taste declined in England, this title was assumed by men who had not the slightest right, judged either by their aims or by their results, to be considered artists; and to-day it is fallen into such disrepute that it is often replaced by "landscape-architect." French usage supports this term, and it is in many respects a good one. But its derivative, "landscape-architecture," is unsatisfactory; and so, on the other hand, is "landscape-artist," although "landscape-art" is a good general term. Perhaps the best we can do is to keep to "landscape-gardener," trying to remember that it ought always to mean an artist and an artist only, but that this artist is not always called upon to design landscapes, either large or small, or even naturalistic gardens.

The landscape-gardener, when his title is most appropriate, stands with the sculptor and the painter, in contrast to the architect, in that he takes his inspiration directly from Nature, working after the schemes and from the models which she supplies. But in some 
respects he stands quite alone. The painter works with actual colors, but with mere illusions of form, and the sculptor creates forms but uses colors, if at all in conventional and subordinate ways; but the landscapegardener depends upon color and form in equal measure, and can never dispense with the one or the other. Thes again, he takes from Nature not only his models but his materials and methods. His colors are those of her own palette, his clays and marbles are her rocks and soils, and his technical processes are the same that she employs. He does not show her possibilities of beauty as in a mirror of his own inventing. He helps her in her actual efforts to realize them-he works in and for and with her.

This fact limits and hampers him in certain ways; but, under fortunate conditions, it allows him to achieve what no other artist can-perfection. "The sculptor or the painter," writes a recent critic, "observes defects in the single model ; he notices in many models scattered excellences . . . . To correct those defects, to re-unite those excellences, becomes his aim. He cannot rival Nature by producing anything exactly like her work, but he can create something which shall show what Nature strives after.

". . . . The mind of man comprehends her effort and though the skill of man cannot compete with her in the production of particulars, man is able by art to anticipate her desires and to exhibit an image of what she was intending." But the landscape-gardener is Nature's rival, does create things like her own, can compete with her in perfect workmanship, for she herself works with him while he is re-uniting her scattered 
excellences and obliterating her defects. What he cannot do she does for him, from the building of mountains and the spreading of skies to the perfecting of those "particulars" which turn the keenest chisel and blunt the subtilest brush - to the curling of a fern-frond and the veining of a rose. Of course she will not everywhere do everything. If part of her work is in completing man's, part is in preparing for it, and he must respect the canvas and frame which she furnishes for his picture, the general scheme which she prescribes. $\mathrm{He}$ cannot ask her to build him mountains in a plain, to change a hill-side rivulet to a river, or to make tropical trees grow under northern skies. But he can always persuade her to produce beauty of some sort, if he is wise enough to know for what sort he should ask.

This, of course, is true only in a theoretic sense. Theoretically, there is not a spot on earth an artist could not beautify. But some spots would demand a life of antediluvian length, and dollars as plentiful as the sands by the sea. Practically, the landscapegardener, perhaps more than any other artist, is limited by questions of time and money. And his partnership with Nature limits him as regards not only the sort but the degree of beauty which he can achieve. Nature may suggest the same sort in two places, but if she prepares lavishly for it in the one spot and parsimoniously in the other, the best skill in the world may not be able to succeed as well here as there. Yet, I say, the landscapegardener can always count upon that perfection in details which painter and sculptor never get; and his general effects as well as his details have the great advantage of being alive. A great advantage indeed, for 
it means many beautiful results in every piece of work instead of merely one, and perpetual variation in each of the many. His aim is, in general, the same as that of the landscape-painter, who knows that the most potent factors in Nature's beauty are light and atmosphere. No things in the world, not even the color and texture of the human skin, are so difficult to simulate, so impossible to imitate in paint as these. But to the landscapegardener's pictures Nature freely supplies them, and not only in the one phase for which a painter strives, but in a thousand, changing them with each day of the year and each hour of the day. And with the passing days and seasons she changes also his terrestrial effects, so that no part of his work is twice the same, although, if rightly wrought, it is always beautiful.

But does not this partnership with Nature deprive the artist of the chance for self-expression? Art, after all, is not imitation but interpretation; and interpretation implies the exercise of choice and inventiveness, the revelation of personal thought. No artist can copy Nature, and if he could his work would not be worth while. Its only value would be historical, not artistic; it would be prized only as the permanent record of a perishable fact. To make his result worth while as art, he must put into it a portion of himself.

If the landscape-gardener were indeed denied the chance to do this he could not be more than a skilful artisan. But he is not denied it. In fact, he cannot escape if he would from the necessity for self-expression. It is not truer to say of him than of the painter or the sculptor that he copies Nature. Although they work merely with their eyes upon Nature, and he works 
in and with her, his aim is the same as theirs - to reunite her scattered excellences. Theoretically he could copy her in a very exact sense of the word; but practically he can copy little more than her minor details and her exquisite finish of execution. Composition of one sort or another is the chief thing in art, and the landscapegardener's compositions must be his own. Through them he must express his own ideals. If he is Nature's pupil he is also her master.

"Nature," writes Aristotle, "has the will but not the power to realize perfection." Turn the phrase the other way and it is quite as true: she has the power but not the will. In either reading it means that man can aid and supplement her work. The landscape-gardener can bend her will in many ways to his own, although he must have learned from her how to do it. He cannot achieve things to which her powcr is unequal, but he can liberate, assist, and direct that power. He could even remove her mountains if the result were worth the effort; and he can blot them out of his landscape by the simplest of devices-by planting a clump of trees and shrubs which she will grow for him as cheerfully as though she herself had sown their seeds. He cannot make great rivers; but he can make lakes from rivulets and cause water to dominate in a view which Nature has spread with green grass. He can even teach her to create exquisite details scarcely hinted at in her unassisted products. All "florists' roses," for example, are not beautiful; but there are many in which Nature herself may grudge man's skill its major share. In short, the landscape-gardener's task is to produce beautiful pictures. Nature supplies him with his materials, al- 
ways giving him vitality, light, atmosphere, color, and details, and often lovely or imposing forms in the conformation of the soil; and she will see to the thorough finishing of his design. But the design is the main thing, and the design must be of his own conceiving.

It is easy to see that this is true when formal, "architectural" garden-designing is in question. But it is just as true of naturalistic landscape-work. Nature seldom shows a large composition which an artist would wish to reproduce; and if by chance she does, it is impossible for him to reproduce it. Practical difficulties hedge him narrowly in, and appropriateness controls his efforts even more imperiously than those of other artists. His aim is never purely ideal; he can never think of beauty or even of fitness, in the abstract. He may practise with abstract problems on paper, but with each piece of his actual work Nature says to him: "Here in this spot $I$ have drawn a rough outline which it is for you to make into a picture. In many other spots I have shown you scattered beauties of a thousand kinds. It is for you to decide which you can bring into your work, and to discover how they may be fused into a whole which shall look as beautiful, as right, as though I had created it myself." Appropriateness must be the touchstone for particular features as for general effects. The artist's memory may be stored with endless beauties - with innumerable "bits" of composition and good ideas for foregrounds, middle distances, and backgrounds, and with exhaustless materials in the way of trees and shrubs and flowers. But not one of these can be used until he has considered whether it will be theoretically appropriate in this part of the world, in 
a scheme of this special sort, and whether, if it is, practical considerations will permit its use.

Indeed, the true process for landscape-work is more imaginative than this. The true artist will not go about with a store of ready-made features and effects in his mind, and strive to fit some of them into the task of the moment as best he may. He will conceive his general idea in deference to the local commands of Nature; develop his general scheme as artistic fitness counsels; discover the special features which are needed to complete it (considering which Nature will permit among those he might desire); and then, half unconsciously perhaps, search for memories of natural results which may teach him how to achieve his own. In educating himself he will have tried less to remember definitely this and that particular natural result than to understand how Nature goes to work to produce beautiful results. He will have tried to permeate himself with her spirit, to comprehend her aims, to learn what she means by variety in unity, by effective simplicity, by harmonious contrasts, by fitness of feature and detail, by beauty of line and color, by distinctness of expression -in a word, by composition. He will have tried to train his memory for general rather than for particular truths, and chiefly to purify his taste and stimulate his imagination; for he will have known that while, in some ways, he is Nature's favorite pupil, in others she treats him more parsimoniously than the rest. She gives him a superabundance of models by the study of which he may make himself an artist; but when, as an artist, he is actually at work, she will never give him one pattern which, part by part, can guide his efforts. When we 
read of painters, we marvel most, not at the modern "realist" working inch by inch from the living form, but at Michael Angelo on his lonely scaffold, filling his ceiling with forms more powerful and superb than Nature's - no guides at hand but his memory of the very different forms he had studied from life, and his own creative thought. Yet something like this is what the landscape-gardener must do every time he starts a piece of work. Certainly not each of his tasks is as difficult as a Sistine ceiling, but each, whether small or 'great, must be approached from an imaginative standpoint.

There is another point to be noted. When we speak of the artist as taught and inspired by "natural" scenes, we are apt to mean all those which have not been modified by the conscious action of art. We recognize a park-landscape as non-natural; but those rural landscapes in cultivated countries from which the designer of a park draws his best lessons are also non-natural. "If, in the idea of a natural state," says an old English writer, "we included ground and wood and water, no spot in this island can be said to be in a state of Nature.

Wherever cultivation has set its foot-whereever the plough and spade have laid fallow the soilNature is become extinct."

Extinct is, of course, too strong a word if we take it in its full significance. But it is not too strong if we understand it as meaning those things which are most important to the landscape-gardener; the compositions, the broad pictures, of Nature have been wiped out in all thickly settled countries. The effects we see may not be artistic effects, may not have resulted from a conscious effort after beauty; but they are none 
the less artificial. They do not show us what Nature wants to do or can do, but what man and Nature have chanced to do together. When English artists became dissatisfied with the formal, architectural gardening of the seventeenth century, they fondly fancied they were learning from Nature how to produce those aspects of rural freedom, of idyllic repose, of seemingly unstudied grace and charm which were their new desire. But in reality they were learning from the face of a country which for centuries had been carefully moulded, tended, and put to use by man. In some of its parts the effects of man's presence were comparatively inconspicuous. But of most parts it could be said that for ages not a stream or tree or blade of grass had existed except in answer to his efforts, or, at least, in consequence of his permission; and it was these parts, and not the wilder ones, which gave most assistance to the landscapegardener.

Take, for example, the lawn, which is so essential a feature of almost every naturalistic gardening design. It is not true, as often has been said, that Nature never suggests a lawn. But it is true that she did not suggest it to those English gardeners who developed it so beautifully. They were inspired by the artificially formed meadow-lands and forest-glades of the England of their time.

Yet all the semi-natural, semi-artificial beauty of England would not have taught them how to make beautiful parks and gardens had they not been taught by their own imagination too. What they wanted to create was landscapes which should charm from all points of view, bear close as well as distant inspection, 
and be free from all inharmonious details; and, moreover, landscapes which should fitly surround the homes of men and accommodate their very various needs and pleasures. Such landscapes we never find in Nature, not even in cultivated, semi-artificial Nature. That is, while we can imagine a natural spot which would be an appropriate setting for a hunter's lodge or a hermit's cell, we can fancy none which would fittingly encircle a palace, a mansion, or even a modest home for a man with civilized habits and tastes. Every step in civilization is a step away from that wild estate which alone is truly Nature; and the further away we get from it the more imagination is needed to bring the elements of use and beauty which Nature still supplies into harmony with those which man has developed.

The simplest house in the most rural situation needs at least that a path shall be carried to its door; and to do as much as cut a path in the most pleasing possible way needs a certain amount of imagination, of art. How much more, then, is imagination needed in such a task as the laying-out of a great estate, where subordinate buildings must be grouped around the chief one, and all must be accommodated to the unalterable, main, natural features of the scene; where a hundred minor natural features must be harmoniously disposed; where convenient courses for fect and wheels must be provided; where gardens and orchards must be supplied, water must be made at once useful and ornamental, and every plant, whether large or small, must be beautiful in the sense of helping the beauty of the general effect? The stronger the desire to make so artificial a composition look as though Nature might have designed it, 
the more intimate must be the artist's sympathy with her aims and processes, and the keener his eye for the special opportunities of the site she offers; but, also, the greater must be his imaginative power, the firmer his grasp on the principles and processes of art. 


\section{VI \\ CULTURE AND AGRICULTURE** \\ F. W. Howe}

There was a time-not very long ago-when a respectable number of persons who considered themselves well educated had grave doubts whether culture and agriculture were not mutually exclusive terms, persons who did not believe that the ordinary farmer might rationally be considered a man of culture, or perhaps even capable of culture. Indeed, it may be questioned whether this point of view was not quite generally entertained "among our best people." According to this philosophy the only hope for the farmer to acquire culture lay in the possibility that he might somehow rise superior to the natural limitations of his daily work, and school his mind to the contemplation of the nobler things of literature, history, and art. The study of beet roots had not cultural value to be compare with the study of Greek roots, nor alfalfa stems with Latin stems.

This type of thought affected even some of those who gained their living from the farm, but inherited their educational ideals from the past. It is noteworthy even yet that the state colleges of agriculture in the South and East have generally emphasized the study of some foreign language, particularly Latin, as a necessary

* From The Cornell Countryman by permission. 
condition or accompaniment of the study of agriculture, in order to insure their students at least a fraction of the "culture" they might secure in attending other colleges and universities. This notion of the special virtue of foreign language study has been generally less emphasized in the agricultural colleges of the Northern and Western states; but quite generally over the country as a whole, practical assent has been given to the view that the land-grant colleges exist for the benefit of the sons and daughters of farmers who could not afford to pay the cost of attendance at other colleges or universities, or who might feel socially out of place in these institutions, or who might not be able to meet the scholastic requirements of entrance in these other schools.

Possibly it was to remove this last suspicion and to reaffirm the cultural capacity of farmers' children, even when measured by the older scholastic standards, that later on it became the fashion to include a foreign language in the entrance requirements of state colleges of agriculture, especially when connected with older universities. Possibly also a consideration of equity was involved in this later fashion. If the state is to furnish free tuition in agriculture, but does not allow free tuition in all other college courses, perhaps it must justify this policy by imposing a kind of "culture" handicap upon the student of agriculture by requiring him to study some foreign language as a condition of being allowed to study agriculture at state expense. In other words, we may coax him or compel him to acquire culture by studying the necessary cultural subjects before, or along with, his study of agriculture, if the 
agricultural subjects themselves are not cultural enough to develop sufficient culture to satisfy the claims of citizenship.

But suppose this requirement turns out to be a real handicap in securing the special type of training for which the agricultural college was established? What shall we say of the boy or girl who studies agriculture eagerly in the high school, but who does not care for or succeed in the study of the foreign languages? Shall the state deny him the privilege of getting such culture and honor as he can by graduation from the college of agriculture? Does the land-grant college of agriculture exist for the conferring of culture upon its students? And is culture the necessary product of foreign language study? Or is preparation and purpose for usefulness to be considered equal to if not identical with real culture?

But there may be some reasonable difference of opinion as to the meaning of "culture," perhaps even when it is spelled with a $\mathbf{K}$ and enforced with the sword and the submarine. But when we attempt exact definition, it seems well to say that real culture may be defined negatively much more easily than positively. We seem instinctively to know what it is not without being satisfactorily able to say what it is.

For example, I care not how well schooled a man may be, I know that he is not cultured when $I$ hear him swear or see him smoke in the presence of either women or men who object to this infringement of their own rights. If acts like these are compatible with culture, then we either miss little in not having it, or else we must admit that its champions experience occasional lapses 
from their allegiance. On the other hand, a man may do some things that are forbidden by the code of the ultra-cultured without actually losing his claim to gentility. I have heard of a scientific type of agriculture that proposes to produce peas that are flat on one side so that they will not roll off a table knife. And I presume this whimsical proposition is accepted in some quarters as sufficient evidence of the irrepressible conflict between culture and agriculture. But conceivably a man might even eat peas or pie with a knife and be a gentleman still if he absolutely had no fork or spoon to save him from starvation. And so a man may keep his seat in a car while women are standing and yet be a cultured gentleman-for he might be sitting on the window-sill or the hand-rail or on another man's lap; or he might have much further to ride than the lady; or he might be wearied with a long day's work and have a mile or two to walk after leaving the car, while she has just stepped out of an easy chair at home; or, yet again, he might be ill and unable to stand; or perchance he might be reading bchind a paper and never see her at all! And so a gentleman's seat is to be held or surrendered according to the special circumstances of each case. The lady herself is not truly cultured who expects a man to act invariably according to a fixed prescription regardless of conditions.

The essence of culture is considerateness. Culture is not to be learned by memorizing books on etiquette. It is not a slavish following of rules, nor the ability to repeat formulas or pronounce big words or interpret dark sentences. Culture is not anything that must be learned from books or by intimate association with 
select persons or through imitation of distinguished models of excellence. Culture is not anything that can be positively guaranteed as the result of pursuing a prescribed course of study. No student can say, "These and these subjects I shall put into my program, and when I have finished I shall be a man of culture."

Lest these views shall be regarded as merely the pronouncements of personal opinion, let me support them with the statements of a few educators who will be accepted as good authority. President A. Ross Hill, of the University of Missouri, says :

Culture is not inherent in particular forms of subject-matter, but is a by-product of the educational process, and represents an attitude of mind and life rather than a particular kind of knowledge.

And in similar language speaks President R. C. McLaurin, of the Massachusetts Institute of Technology :

Some speak as if the test of culture were the knowledge of Latin, or Greek, or of French literature, or of Italian painting, or of what not. As a matter of fact it is none of these things, for I take it that the root of culture in any worthy sense is the possession of an ideal that is broad enough to form the basis of a sane criticism of life.

Let me add to these words a statement by Professor W. H. Heck, author of "Mental Discipline and Educational Values":

It is a sad commentary upon our educational abstractness that we often fail to realize the high and noble inclusiveness of the ideal of use in our preparation of girls and boys for efficiency and service in society. We sometimes run away from the real test of real things and cry out for culture, as if culture had any meaning apart from its use in adjustment.

Again, Professor John Dewey, of Columbia University :

The assumption that a training is good in general just in the degree in which it is good for nothing in particular, is one for 
which it would be difficult to find any adequate philosophical ground. Training, discipline, must finally be measured in terms of application, of availability. To be trained is to be trained to something and for something.

Finally let me remind you of these words from the late Commissioner Draper, then President of the University of the State of New York:

New York will never relax her grasp upon the things which culture the minds and souls of men, but it is to be hoped that she will realize better than she has that the finest and deepest culture comes through work; that work by the hand and by the head are yoke-fellows in our free civilization, and that both the rights and the prosperity of her people hinge upon the professional and industrial equilibrium of her tax-supported education.

There is a hint in these last. words that we may even professionalize the technical subjects in our agricultural colleges to the extent that we almost entirely obscure or ignore their industrial application. We may so subdivide and elaborate our courses of study that no ordinary student can in four ycar's compass enough of them to equip himself for practical efficiency on the farm. Indeed, this is the criticism most often directed against the agricultural college. Are we, perhaps, getting so much of culture that we are falling short in our agriculture? Is it a fact that our acres are becoming so productive under scientific management that we need have no concern for our future food supply? Under the leadership of the colleges are our farmers becoming so efficient that fewer and fewer will need to stay on the farm? If this be so, do we need to train more and more leaders in agriculture to direct these few, or are the colleges of agriculture devoting themselves to the training of leaders for city life?

It seems to be true that the more freely the college student of agriculture is turned loose in the field of 
specialization, the less frequently does he return to practical agricultural pursuits. It is the admitted aim of some state agricultural colleges, if not the ambition of all, to train their graduates mostly to be "leaders" rather than practical farmers; but it is certain that we must be approaching a condition of equilibrium. The movement of young men from country to city cannot go on indefinitely and yet it is necessary to train in the colleges an increasing number of highly specialized agricultural leaders. We shall soon need to cultivate some people on the farms who are willing to be led. Some of these leaders must actually establish themselves on farms and demonstrate their ability to lead and be led by their college training.

If you ask me whether we have been getting too much culture and too little practical agriculture in the colleges, my answer is, we have been getting too little culture out of our practical agriculture on the farms. We have overlooked or disregarded the culture obtainable directly from agriculture. We need more men educated in scientific agriculture who believe in the cultural possibilities of farm life, and who are practically willing to live in the country and demonstrate to their neighbors the practicability of the culture they have received in the college, and thus to elevate the common life of their own community.

Too many young men from the towns and cities are studying agriculture as a profession rather than as an occupation. They intend to be "gentlemen farmers," but do not intend to work much with their own hands. They expect to "make money" on the farm by using their father's city-earned capital, but they do not 
usually expect to associate with their country neighbors and build up the social and religious life of the neighborhood. So strong seems this tendency of city boys to use their study of agriculture as a means of personal profit rather than community betterment, that colleges of agriculture are coming to be crowded with them. And the inducement of free tuition offered by the state also attracts many others who have no vital, personal interest in farming itself, but merely utilize the college of agriculture as a means of securing a good scientific and social training that can be profitably turned to other occupations.

The state normal schools require prospective students to subscribe to some sort of declaration that they intend to use their training for teaching in the public schools. A similar declaration from every student of agriculture in a tax-supported college of his intention to devote his training to practical agriculture, or to research or teaching in furthering the practice of agriculture, would probably test the elasticity of some consciences. If the requirement of two or three years in a foreign language is intended to discourage such students from rushing into agriculture, I submit that it is a requirement that can be much more easily prepared for in the city schools than in the country, that it is more naturally related to the city boy's mind and environment, and that as a deterrent from agricultural study it is much less effective than a requirement of one year's practical experience on the farm would be.

There can be no question that a year's work on a farm would disclose the city boy's fitness to study agriculture much more positively than the ability to read a selected 
chapter in Cæsar. In fact, to insure that the city boy has at least a fair understanding of what agriculture is and means, and that he has a mental and moral attitude toward it that implies at least some partial return to the state for his free tuition, it would seem a fair requirement that every city boy should have the experience of working for a whole year on a good farm before he presents himself for entrance at a college of agriculture. It seems unfair to the boy himself either to take his money for tuition or to tempt him by free tuition to enter upon a four-year agricultural course without an adequate preliminary conception of what a. course in agriculture ought to mean.

The old conception of culture doubtless grew out of the ambitious tendency of the lower order of society to ape the manners and accomplishments of the higher. In medieval times the priest and the monk must know Latin in order to read the Scriptures and officiate in the rites of the Church. The peasant boy who aspired to the service of the Church looked forward to the mastery of Latin as a vocational requirement; it was to be used in his calling. But to the humbler members of his family his attainment in the use of an unknown tongue became the proof of superior refinement and culture. Likewise the English peasant lad or lass who was fortunate enough to become connected with the retinue of a nobleman must learn French in order to qualify himself for promotion to higher circles of influence. And so with the study of mathematics as a prerequisite for the ancient pursuit of astronomy. In short, all the educational subjects that have attained high esteem for their cultural value were first courted because of their. 
vocational value, as means to the better performance of some social or professional duty. The point I wish to urge here is that Latin still had cultural value for the priest who used it in his service; it did not become cultural by becoming useless. And if this be true, then every useful subject of study may become a means of culture for the actual user, and in a secondary sense it may also become passively cultural for the one who studies it merely for general information without expecting, primarily, to put it to the test of use. We must agree to this point of view unless we are to admit that culture invariably results from the study of that which is fundamentally useless.

What, then, are the possibilities of culture in relation to agriculture? My conviction is that, regardless of whether a man has studied Latin or German, regardless of whether he now eats peas with a knife or a fork, regardless of whether he is the graduate of a college of agriculture or a college of liberal arts, or of none, if he is a real farmer he can unconsciously acquire genuine culture of mind and soul in the routine practice of his daily occupation.

No other occupation compares with modern farming in the opportunity it offers for constant mental progression, if one has the native appetite for progress. If one has it not, or if it has not yet been awakened in the soul, then no study of French or music, art or esthetics, mathematics or metaphysics can make lim a cultured man or woman. Lincoln found culture in a log cabin with two or three books and his own thoughts.

Wealth and ease of life are not the necessary conditions of culture. It cannot be bought with a price or 
put on like a garment. Pianos and fox trots, victrolas and super-sixes, do not bring culture into country homes. It must begin on the inside of the personal and family life and blossom in words and acts that disclose superior character. And no other type of life is more favorable to the development of worthy character than is the work of the farm. The farmer needs only the vision of reality, of seeing the invisible in the visible, to appreciate the essential sacredness of the things with which he deals. He is the chief producer of mankind's daily food, the hand that feeds the world. If the understanding and contemplation of this fact do not bring a sense of the responsibility and dignity of his service, then we have much yet to pray for.

The hope of a wholesome American life lies in the prospect that our farmers may come not only to the full appreciation and discharge of their duty as producers but also to the realization of the full possibilities of personal culture which farming should afford. The burden of our teaching hitherto and the aim of most government activity in the farmer's behalf has been to show him how to produce more bushels and tons per acre; but he knows now how to produce more than it is commonly profitable for him to produce. He does not wish now to be shown how he can live on twenty-five cents a day so much as to be shown how his income will enable him to live as well as he ought to. He is not satisfied with the mode and scale of living nor with the hours of labor that satisfied his grandfather. He wants more of the joy of living. If he was to be kept contented with the peasant's lot his larger education should never have been started by the state. Education 
is ever a disturber of the peace that sleeps in serfdom. Instil in man the taste of knowledge and you awaken a troop of energies that will scale the heights of culture.

What has agricultural learning done to quicken these springs of self-development? Possibly not so much as we could wish for the adult and aged members of the farm home, these survivors from the day when agriculture was not taught in the common schools. But what of the farm boy and girl of to-day? The study of useful plants, birds, and animals, that constitutes an important part of all real farm work, is the most helpful sort of nature study. Companionship with father and mother as well as with brothers and sisters in doing the work of the farm is a kind of education greatly needed in our day. The city boy and girl often go astray because they are so constantly associated only with those of their own inexperienced age when outside the schoolroom. The child of the farm is about the only one who has a fair chance to develop a normal human life. He learns responsibility for his own share of chores and harder work. He learns the value of money, of work, of time, and of recreation. He learns the meaning of duty that must be done at the right time, and the joy of rest after work. He can sleep and enjoy wholesome food and he rarely calls a doctor. He knows the difference between the size of a rabbit and the size of a cow though both pictures may occupy equal space in the book. He knows that milk does not criginally come out of a bottle. He doesn't have to "keep off the grass." He has a thousand sources of information and delight that come only on occasions to the city boy. All these conditions tend to develop a breadth of mind and a 
sturdy resourcefulness that is the best possible preparation for usefulness in later life.

Some city people have worried much over the effect of isolation on the culture of the rural home. It may in fact be considered an advantage rather than a disadvantage. It is true that a certain degree of isolation is characteristic of all farms that are large enough to be profitable. For normal social development the farmer's family must therefore be able in a large degree to entertain themselves at home. The man or woman who must. always be making or returning calls, or attending "parties" will have to develop a more conservative social habit if he gives needed time, energy, and thought to making his farm business successful. One of the great moral advantages of country life is that it tends to develop the habit of meditation while at work. A good countryman must be "gond company" for himself and his own family. His personality must be of a high type. As Warren put it in relation to dairying, "No one can produce clean milk who does not have a clean body and a clean mind." As a matter of social fact, there is often more of real, helpful friendship between farm families who live two or three miles apart than exists between those living on adjacent city lots. A certain degree of seclusion is good for every family that is not dependent on neighbors for inspiration in its own home life.

I have already alluded to the teaching of agriculture in the rural school. We are passing the day when the country school and its teacher drew all their inspiration from the activities of urban life. And I hope we are passing the day when the rural church and its pastor 
drew inspiration chiefly from the same source. The rural school that does not use its natural environment as subject matter and illustration for teaching does not encourage boys and girls to stay on the farm. And the rural church whose pastor never preaches in terms of country life, and whose congregation never interests itself in community betterment, does not perform its full duty to the state which exempts its property from taxation. If the church is merely an exclusive social club, its property should be taxed like that of any other private club. The church particularly, because it is not supported by taxation, can never thrive in an unprosperous farming community. For its own preservation it must recognize the obligation to do its share in promoting the economic welfare of its neighborhood. The rural preacher should know at least enough about farming to interest farmers themselves in the agriculture of the Bible as a means of teaching religious truth. One of the highest possibilities of country life is disclosed in the natural relationship between good preaching and good farming. This relationship is more than economic, but it grows out of consistent economic views and principles.

If this discussion has wandered far afield, let us now, in conclusion, return like the preacher to his text. Culture and Agriculture are not opposing terms. We are to believe and learn that agriculture needs no importation of goods from any other realm to provide food for the care and culture of men. As the fields of the earth bring forth all manner of fruits for the sustenance of the physical life, so also does their cultivation afford stimulus and direction to the mental and 
moral life. For no one can be a successful husbandman who does not follow the law of Nature, which is the law of God. "The Holy Earth" is the source of thoughts that reach to the Infinite, if we listen to her teaching.

Culture is the product of thoughtfulness, the understanding of facts, the appreciation of truth. If it be said that culture involves the love of poetry, all nature is a poem. If it includes a mastery of science, the farmer must be the broadest scientist. If it calls for statesmanship, farming itself is the foundation of the state. If it demands derotion to the arts, the husbandman is the keenest craftsman of them all. And if it requires creative genius to generate culture, the master of the farm is himself a creator of value, of beauty, of influence, and of new knowledge for the world's instruction.

If the farmer of to-day is not living up to the cultural possibilities inherent in his calling, it is because he is deaf and blind to spiritual invitations that solicit him to the mastery of forces that have produced the miracles and the wisdom of the ages. For most of us culture must take root in vocation, it cannot be brought from afar. But he who holds the plow may yet look off and look up. His mind may be busy with the conquest of the world. There is no enmity between culture and agriculture. 





\section{VII}

\section{'THE FARMER: THE CORNER-STONE OF CIVILIZATION *}

\section{Theodore Roosevelt}

Recentuy an Indiana woman was peeling some potatoes, and in a hollow in one she found a note from the Southern farmer who had raised the potatoes running:

"I got $69 \mathrm{c}$ a bushel for these potatoes. How much did you pay for them?"

She wrote back:

"I paid \$4 per bushel."

The farmer sent her just one more letter. It said:

"I got $69 \mathrm{c}$ for these potatoes. It could not have cost more than 31c to carry them to you. Who got the other \$3? I an going to try to find out."

It is idle to say that when such an occurrence is typical-and it most certainly is to a large extent typical-there is no cause for uneasiness. Something is wrong. It may be wholly the fault of outsiders. It may be at least partially the fault of the farmers and of those who eat the food the farmers raise. The trouble may be so deep-rooted in our social system that extreme caution must be exercised in striving for betterment. But one thing is certain. The situation is not satis-

* From "The Foes of Our Own Household," by Theodore Roosevelt. Copyright, 1917, George H. Doran Co., Publishers. 
factory and calls for a thoroughgoing investigation, with the determination to make whatever changes, including radical changes, are necessary in order once more to put on a healthy basis the oldest and most essential of all occupations, the occupation which is the foundation of all others, the occupation of the tiller of the soil, of the man who by his own labor raises the raw material of food and clothing, without which the whole fabric of the most gorgeous civilization will topple in a week.

We cannot permanently shape our course right on any international issue unless we are sound on the domestic issues; and this farm movement is the fundamental social issue-the one issue which is even more basic than the relations of capitalist and workingman. The farm industry cannot stop; the world is never more than a year from starvation; this great war has immensely increased the cost of living without commensurately improving the condition of the men who produce the things on which we live. Even in this country the situation has become grave.

The temporary causes of this situation have produced such effect in our land only because they aggravated conditions due to fundamental causes which have long been at work. These fundamental causes may all be included in one: the farmer's business in our country has remained almost unchanged during the century which has seen every other business change in profound and radical fashion. He still works by methods belonging to the day of the stage-coach and the horse canal-boat, while every other brain or hand worker in the country has been obliged to shape his methods into 


\section{THE CORNER-STONE OF CIVILIZATION 81}

more or less conformity to those required by an agc of steam and electricity.

Our commercial, banking, manufacturing, and transportation systems have been built up with a rapidity never before approached. We have accumulated wealth at an unheard of rate. There has been grave injustice in the distribution of the wealth, our law-givers having erred both by wisdom in leaving the matter alone, and at times by even greater unwisdom when they interfered with it. But on the whole the growth and prosperity have been enormous; and yet we have allowed the basic industry of farming, the industry which underlies all economic life, to drift along haphazard, we have allowed the life of the dwellers in the open country to become more and more meager, and their methods of production and of marketing to remain so primitive that their soil was impoverished and their profits largely usurped by others.

In 1880 , one farmer in four was a tenant; and at that time the tenant was still generally a young man to whom the position of tenant was merely an intermediate step between that of farm laborer and that of a farm owner. In 1910, over one farmer in three had become a tenant; and nowadays it becomes steadily more dificult to pass from the tenant to the owner stage. If the process continues unchecked, half a century hence we shall have deliberately permitted oursclves to plunge into the situation which brought chaos in Ireland, and which in England resulted in the complete elimination of the o.d yeomanry, so that nearly nine tenths of English farmers to-day are tenants and the consequent class division is most ominous for the future. France and Germany are 
to-day distinctly better off than we are in this respect; and in New Zealand, where there is an excellent system of land distribution, only one seventh of the farmers are tenants.

If the tendencies that have produced such a condition continue to work unchecked no prophetic power is needed to foretell disaster to the nation. Therefore, the one hopeless attitude, in this as in recent international matters, is "watchful waiting," sitting still and doing nothing to prepare for or to avert disaster. It is far better to try experiments, even when we are not certain how these experiments will turn out, or when we are certain that the proposed plan contains elements of folly as well as elements of wisdom. Better "trial and error" than no trial at all. And the service test, the test of actual experiment, is the only conclusive test. It is only the attempt in actual practice to realize a realizable ideal that contains hope. Mere writing and oratory and enunciation of theory, with no attempt to secure the service test, amounts to nothing.

This applies to the tenancy problem. It also applies to every other farming problem. As regards each, let us test the plans for reform, so far as may be, by actual practice.

For many of these plans the several states offer themselves as natural laboratories, where experiments can be tried when conditions and public opinion are right; and this although the permanent remedies must ultimately, at least in major part, be national. It is exceedingly interesting to watch such an experiment as that seemingly to be tried in North Dakota. This is a farming state, where the farming is the predominant 
interest, and inasmuch as all reforms cost money, and as even advisable reforms become utterly disastrous if in spending money upon them we treat "the sky as the limit," and decline to consider the proportion between what the reform achieves and what it costs, it is well that the farmers themselves should pay a good proportion of the cost of reforms necessary to and peculiarly affecting themselves. In North Dakota, in addition to matters like hail insurance, it is proposed that the state shall purchase and operate grain elevators, mills, and terminals, and other business instrumentalities of vital concern to farmers. I most heartily commend the earnest effort the leaders in the movement have made actually to better conditions; and I say this although from the facts at my command $I$ judge that most of the work which it is thus proposed to have done by the state could be done better by coöperative societies among the farmers themselves. Present conditions should certainly be changed. To keep them unchanged is to act in a spirit of mere Toryism. From the North Dakota experiment, when put in actual practice, we can learn some things to follow and some things to avoid; and perhaps we can also learn to be wise in time, and, by sane determination to put in practice reforms that we are reasonably sure will have no bad effects, avoid the sad necessity of paying with our own skins for experiments which probably will have bad effects.

I greatly prefer to see the Government leave untouched whatever the corporations under Government supervision can do ; and just as far as possible I want to see all the corporations made into coöperative asso- 
ciations. But there are things so important that the Government must do them, if it is only through such exercise of collective power that they can be done.

Our object must be (1) to make the tenant farmer a landowner; (2) to eliminate as far as possible the conditions which produce the shifting, seasonal, tramp type of labor, and to give the farm laborer a permanent status, a career as a farmer, for which his school education shall fit him, and which shall open to him the chance of in the end earning the ownership in fee of his own farm; (3) to secure coöperation among the small landowners, so that their energies shall produce the best possible results; (4) by progressive taxation or in other fashion to break up and prevent the formation of great landed estates, especially in so far as they consist of unused agricultural land; (5) to make capital available for the farmers, and thereby put them more on equality with other men engaged in business; (6) to care for the woman on the farm as much as for the man, and to eliminate the conditions which now so often tend to make her life one of gray and sterile drudgery; (7) to do this primarily through the farmer himself, but also when necessary, by the use of the entire collective power of the people of the country; for the welfare of the farmer is the concern of all of us.

The most important thing to do is to make the tenant farmer a farm owner. He must be financed so that he can acquire title to the land. In New Zealand the government buys land and sells it to small holders at the price paid with a low rate of interest. Perhaps our Government could try this plan, or else could outright advance the money, charging three and a half per cent. 


\section{THE CORNER-STONE OF CIVILIZATION 85}

interest. Default in payments-which should of course be on easy terms-would mean that the land reverted to the Government. The experience of the firms which have loaned to the largest number of people to acquire homes on small instalment payments has been that foreclosure occurs in a very small percentage of cases; but it would have to be absolutely understood that no failure to pay would be tolerated; for such toleration would in the end discredit the whole system, and work ruin to the honest and hard-working men who would pay. We could follow the precedents established in connection with the reclamation act in the arid and semi-arid regions of the West. It would be desirable, and entirely feasible, to try the experiment first on a small scale, in experimental fashion; and then to apply it on a larger and larger scale with the modifications shown to be necessary in actual practice.

To break up the big estates it might be best to try the graduated land tax, or else to equalize taxes as between used and unused agricultural land, which would prevent. farm land being held for speculative purposes. There can without question be criticism of either proposal. If any better proposal can be made and tried we can cheerfully support it and be guided in our theories by the way it turns out. But we ought to insist on something being done-not merely talked about. Every one is agreed that we ought to get more people "back to the land"; but talk on the subject is utterly useless unless we put it in concrete shape and secure a "service test" even though it costs some money to furnish the means for doing what we say must be done.

As regards furnishing capital to the farmer, the first 
need is that we shall understand that this is essential, and is recognized to be essential in most civilized lands outside of Russia and the United States, but especially in Denmark, France, and Germany. Our farmers must have working capital. The present laws for providing farm loans do not meet the most important case of all, that of the tenant farmer, and do not adequately provide for the land-owning farmer. An immense amount of new capital-an amount to be reckoned in billions of dollars-is needed for the proper development of the farms of the United States, in order that our farmers may pass from the position of under-production per acre, may improve and fertilize their lands, and so stock them as both to secure satisfactory returns upon the money invested and also enormously to increase the amount of food produced, while permanently enhancing the value of the land. Lack of capital on the part of the farmer inevitably means soil exhaustion and therefore diminished production. The farmer who is to prosper must have capital; only the prosperous can really meet the needs of the consumer; and in this, as in every other kind of honest business, the only proper basis of success is benefit to both buyer and seller, producer and consumer.

To achieve certain of these objects it may be necessary to make use of the Government; but wherever possible it is better to use private, usually corporate or coöperative, effort. I believe that the day is coming when many kinds of successful business will admit, and insist on, an alloy of philanthropy. It often adds to, instead of diminishing, business success, to become within reasonable limits one's brother's keeper. (Is it 


\section{THE CORNER-STONE OF CIVILIZATION 87}

necessary to say that in this as in everything else there is need of common sense?)

The Jewish Agricultural and Industrial Aid Society has actually tried the experiment of a land bank to help men become farmers. In seventeen years, at an outlay of two million dollars, it has established thirty-five hundred families on farms; and the losses have been small. The manager of this society is now head of the Federal Land Bank in Springfield, Massachusetts. He has proposed an agrarian land bank to do for the United States as a whole what it has already taken part in successfully doing for some thousands of people. Such a land bank would aid tenants to become landowners, agricultural laborers to become small farmers, and landless immigrants with a farming past to go out on the landwhere we need them.

California, under the wise administration of Hiram Johnson, pointed the path for advance in this as in so many other directions. She has begun the development of five thousand acres, not by merely throwing the land open for settlement, but by building roads, schoolhouses, and even certain "improvements" on farms of suitable size; the effort has been to help the man who wishes to farm to go into the country and there find livable conditions.

Whenever farmers themselves have the intelligence and energy to work through coöperative societies this is far better than having the state undertake the work. Community self-help is normally preferable to using the machinery of government for tasks to which it is unaccustomed. This applies to the ownership of granaries, slaughterhouses, and the like. There are in Europe 
coöperative farmers' associations which own and run at a profit many such institutions; and when this is shown to be the case, the other owners of such agencies face the accomplished fact; and it often becomes possible for the farmers then to deal with them on a satisfactory basis.

In Europe these great farmer coöperative associations sometimes control the whole machinery by which their products are marketed. Each little district has its own coöperative group. The groups of all the districts in the state are united agnin in a large coöperative unit. In this way they do collectively what is beyond the power of any one farmer individualiy to accomplish. By sending their shipments to market they move them in great bulk-quantities at the lowest possible cost. They contract for long periods ahead and sell in the most advantageous market. Middlemen are eliminated. The labor of moving farm products is reduced to a minimum. But these enterprises are not state enterprises. The relationship of the state to them is confined to supervision, just as our bank examiners supervise the association of stockholders who come together to do a banking business; and certain general regulations that are in the interest of public policy are imposed upon them. A standard of equity and fair dealing is maintained by the forcing of the publication of accounts and by supplying disinterested examiners who see to it that equity is preserved by honesty and fairness among those associated in the enterprise.

Of course the personal equation is all important; the best of schemes will work badly if we force it against the fundamental issues of fairness and honesty. 


\section{THE CORNER-STONE OF CIVILIZATION 89}

A single farmer to-day is no match for the corporations, railroads, and business enterprises with which he must deal. Organized into coöperative associations, however, the farmer's power would be enormously increased. The principle upon which such coöperative groups are formed is very simple. The profits are divided partly into the shape of a rebate that is paid in proportion to the volume of business done for each member. The control, however, of the association does not depend upon the number of shares that a member may own but rests upon the democratic basis of one man, one vote. In such associations they elect their own officers who are specifically qualified to deal with the agricultural problems of the association. These officers are subject to the direct control of those whose business and interests they handle. In this way politics is kept out of the farmer's business. Through coöperative organization our farmers can build up their strength.

And normally they can do better in this way than by recourse to an extreme form of state Socialism. The farmers of Denmark, Holland, and parts of France, North Italy, and Germany have pointed the way. In Denmark on a country road in the afternoon one can see a man wearing a cap of the coöperative association push a light wagon through the village, gathering from each house a dozen or two dozen eggs and a roll of butter and cheese. As he takes it he stamps the eggs and records the quantity delivered in the record book of the member. At the end of his three or four mile trip he meets a half-dozen other men at a small transfer station owned by the coöperative association. There wagons or trucks load the products brought in and haul 
them to a near-by railroad station where the trucks from five or six transfer stations gather and fill a railroad car. The railroad car starts and in its journey to the seaport meets several dozen additional cars loaded with the products of the association. At the seaport a ship load is waiting and the entire train load of products is loaded and started for England. In England this ship is unloaded in the warehouse of an English coöperative association. 'The products-butter, eggs, cheese, milk, and other standard farm outputs-have been contracted for on a sliding scale on a yearly basis in advance. Between the peasant farmer of Denmark and the workingman consumer in London there is no middleman. Handling charges are reduced to the minimum. The gain goes to the producer in the shape of almost the full price and to the consumer in the shape of reduced cost. The coöperative farmers' association of Denmark buys saltpeter and nitrates in Chili by the shipload, and distributes them as they are unloaded in carload lots to the coöperative associations in every village at a handling charge that is almost insignificantly small. This is the right way for farmers to organize.

Examples of what is done in foreign lands are of great use; yet we must always adapt them to our own needs, and not merely copy them; for no scheme of national betterment can succeed unless it takes into account national characteristics. Experiments in our own country therefore have a peculiar guidance value for us. For this reason those interested in the problem of farm life can well afford to pay some attention to what is at this moment being done in certain districts of our own country. 


\section{VIII}

\section{THE NEW FARMER *}

\section{Kenyon L. Butterfield}

Alu farmers may be divided into three classes. There is the "old" farmer, there is the "new" farmer, and there is the "mossback." The old farmer represents the ancient régime. The new farmer is the modern business agriculturist. The mossback is a medieval survival. The old farmer was in his day a new farmer; he was "up with the times," as the times then were. The new farmer is merely the worthy son of a noble sire; he is the modern embodiment of the old farmer's progressiveness. The mossback is the man who tries to use the old methods under the new conditions; he is not "up" with the present time, but "back" with the old times. Though he lives and moves in the present, he really has his being in the past.

The old farmer is the man who conquered the American continent. His axe struck the crown from the monarchs of the wood, and the fertile farms of Ohio are the kingdom he created. He broke the sod of the rich prairies, and the tasseling cornfields of Iowa tell the story of his deeds. He hitched his plow to the sun, and his westward lengthening furrows fill the world's granary.

*From "Chapters in Rural Progress," by permission of the publishers, University of Chicago Press. 
The new farmer has his largest conquests yet to make. But he has put his faith in the strong arm of science: he has at his hand the commercial mechanism of a world of business. He believes he will win because he is in league with the ongoing forces of our civilization.

The mossback cannot win, because he prefers a flintlock to a Mauser. He has his eyes upon the ground, and uses snails instead of stars for horses.

The old farmer was a pioneer, and he had all the courage, enterprise, and resourcefulness of the pioneer. He was virile, above all things else. He owned and controlled everything in sight. He was a state-builder. Half a century ago, in the Middle West, the strong men and the influential families were largely farmers. Even professional men owned and managed farms, frequently living upon them. The smell of the soil sweetened musty law books, deodorized the doctor's den, and floated as incense above the church altars.

The new farmer lives in a day when the nation is not purely an agricultural nation, but is also a manufacturing and a trading nation. He belongs no longer to the dominant class, so far as commercial and social and political influences are concerned. But none of these things move him. For he realizes that out of this seeming decline of agriculture grow his best opportunities. He discards pioneer methods because pioneering is not now an effective art.

The mossback sees perhaps clearly enough these changes, but he does not understand their meaning, nor does he know how to meet them. He is dazzled by the romantic halo of the good old times, dumfounded by the electric energy of the present, discouraged and dis- 
tracted by the pressure of forces that crush his hopes and stifle his strength.

Economically, the old farmer was not a business man, but a barterer. The rule of barter still survives in the country grocery where butter and eggs are traded for sugar and salt. The old farmer was industrially selfsufficient. He did not farm on a commercial basis. He raised apples for eating and for cider, not for marketthere was no apple market. He had very little ready money, he bought and sold few products. He traded. Even his grain, which afterwards became the farmer's great cash crop, was raised in small quantities and ground at the nearest mill-not for export, but for a return migration to the family flour-barrel.

The new farmer has always existed-because he is the old farmer growing. He has kept pace with our industrial evolution. When the régime of barter passed away, he ceased to barter. When the world's market became a fact, he raised wheat for the world's market. As agriculture became a business, he became a business man. As agricultural science began to contribute to the art of farming, he studied applied science. As industrial education developed, he founded and patronized institutions for agricultural education. As alertness and enterprise began to be indispensable in commercial activity, he grew alert and enterprising.

The mossiback is the man who has either misread the signs of the times, or who has not possessed the speed demanded in the two-minute class. He is the old farmer gone to seed. He tries to fit the old methods to the new régime.

But it is not sufficient to picture the new farmer. 
You must explain him. What is it that makes the new farmer? Who is he? What are his tools? In the first place, you cannot explain the new farmer unless you know the old farmer. You cannot have the new farmer unless you also have the mossback. The new farmer is a comparative person, as it were. You have to define him in terms of the mossback. The contrast is not between the old farmer and the new, for that is merely a question of relative conditions in different epochs of time. The contrast is between the new farmer and the mossback, for that is a question of men and of their relative efficiency as members of the industrial order. Then, of course, you must observe the individual traits that characterize the new farmer, such as keenness, business instinct, readiness to adopt new methods, and, in fact, all the qualities that make a man a success to-day in any calling. For the new farmer, in respect to his personal qualities, is not a sport, a phenomenon. He does not stand out as a distinct and peculiar specimen. He is a successful American citizen who grows corn instead of making steel rails.

But you have not yet explained the new farmer. These personal traits do not explain him. It may be possible to explain an individual and his success by calling attention to his characteristics, and yet you cannot completely analyze him and his career unless you understand the conditions under which he worksthe industrial and social environment. Much less can you explain a class of people by describing their personal characteristics. You must reach out into the great current of life that is about them, and discern the direction and power of that current. 
Now, the conditions that tend to make the new farmer possible may be grouped in an old-fashioned way under two heads. In the old scientific phrases the two forces that make the new farmer are the "struggle for life" and "environment," or, to use other words, competition and opportunity.

Competition has pressed severely upon the farmer, competition at home and competition from other countries. At one time the heart of the wheat-growing industry of this country was near Rochester, N. Y., in the Genesee Valley; but the canal and the railway soon made possible the occupation of the great granary of the West. A multitude of ambitious young men soon took possession of that granary, and the flour-mills were moved from Rochester to Minneapolis. This is an old story, but the same forces are still at work. There has been developed a world-market. The sheep of the Australian bush have become competitors of the flocks that feed upon the green Vermont mountains and the Ohio hills. The plains of Argentina grow wheat for London. Russia, Siberia, and India pour a constant stream of golden grain into the industrial centers of Western Europe, and the price of American wheat is fixed in London. These forces have produced still another kind of competition; namely, specialization among farmers. Localities particularly adapted to special crops are becoming centers where skill and intelligence bring the industry to its height. The truckfarming of the South Atlantic region, the fruit-growing of western Michigan, the butter factories of Wisconsin and Minnesota, have crowded almost to suffocation the small market-gardener of the northern town, the man 
with a dozen peach trees, and the farmer who keeps two cows and trades the surplus butter for calico. These things have absolutely forced progress upon the farmer. It is indeed a "struggle for life." Out of it comes the "survival of the fittest," and the fittest is the new farmer.

But along with competition has come opportunity. Indeed, out of these very facts that have made competition so strenuous spring the most marvelous opportunities for the progressive farmer. Specialization brings out the best that there is in the locality and the man. It gives a chance to apply science to farming. Our transportation system permits the peach growers of Grand Rapids to place their crops at a profit in the markets of Buffalo and Pittsburg; the rich orchards and vineyards of Southern California find their chief outlet in the cities of the manufacturing Northeastthree thousand miles away. During the forty years, from 1860, the exports of wheat from this country increased from four million bushels annually to one hundred and forty million bushels; of corn, from three and one third million bushels to one hundred and seventy-five million bushels; of beef products, from twenty million pounds to three hundred and seventy million pounds; of pork products, from ninety-eight million pounds to seventeen hundred million pounds. And not only do the grain and stock farmers find this outlet for their surplus products, but we are beginning to ship abroad high-grade fruit and first-class dairy products in considerable quantities. Low rates of freight, modern methods of refrigeration, express freight trains, fast freight steamers-the whole machinery of the com- 
mercial and financial world are at the service of the new farmer. Science, also, has found a world of work in ministering to the needs of agriculture, and in a hundred different ways the new farmer finds helps that have sprung up from the broadcast sowing of the hand of science.

But perhaps even more remarkable opportunities come to the new farmer in those social agencies that tend to remove the isolation of the country; that assist in educating the farmer broadly; that give farmers as a class more influence in legislature and congress; and that, in fine, make rural life more worth the living. The new farmer cannot be explained until one is somewhat familiar with the character of these rural social agencies.

It must not be supposed that every successful farmer is necessarily a supporter of all of these social agencies. He may be a prosperous farmer just because he is good at the art of farming, or because he is a keen business man. But more and more he is coming to see that these things are opportunities that he cannot afford to disregard. Indeed, some of these institutions are largely the creation of the new farmer himself. He is using them as tools to fashion a better rural social structure.

But they also fashion him. They serve to explain him, in great part. Competition inspires the farmer to his best efforts. The opportunity offered by these new and growing advantages gives him the implements wherewith to make his rightful niche in the social and industrial system.

It would be erroneous to suppose that the new farmer 
is a rara aris. He is not. The spirit pervading the ranks of farmers is rapidly changing. We have been in a state of transition in agriculture. But the farther shore has been reached and the bridge is possible. The army of rural advancement is being recruited with great rapidity. The advance guard is more than a body of scouts, it is an effective brigade.

I want also to make a plea for the mossback. He must not be condemned utterly. Remember that competition among farmers has been intense; that rural environment breeds conservatism. Remember also that the farmer cannot change his methods as rapidly as can some other business men. Remember, too, that there is comparatively small chance for speculation in agriculture; that large aggregates of capital cannot be collected for farming, and consequently, that the approved means for securing immense wealth, great industrial advancement, and huge enterprises are nearly absent in agriculture. Remember that the voices calling from the city deplete the country of many good farmers as well as many poor ones. Moreover, there are many men on farms who perhaps don't care for farming, but who for some reasons cannot get away. On the farm a man need not starve; he can make a livelihood. Doubtless this simple fact is responsible for a multitude of mossbacks. They can live without strenuous endeavor. Possibly a good many of us are strenuous because we are pushed into it. So I have a good deal of sympathy for the mossback, and a mild sort of scorn for some of his critics, who probably could not do any better than he is doing if they essayed the gentle art of agriculture. I also have sympathy for the mossback 
particularly because he is the man that needs attention. The new farmer takes the initiative. He patronizes these opportunities that we have been talking about. But the mossback, because he is discouraged, or because he is ignorant, or perhaps merely because he is conservative, takes little interest in these things. About one farmer in ten belongs to some sort of farmers' association. Thousands of farmers do not take an agricultural paper, and perhaps millions of them have not read.an agricultural book. Right here comes in another fact. Every "new" farmer when full grown competes with every mossback. The educated farmer makes it still harder for the ignorant farmer to progress.

The future of the American farmer is one of the most pregnant social problems with which we have to deal. There is indeed an issue involved in the success of the new farmer that is still more fundamental than any yet mentioned. The old farmer had a social standing that made him essentially a middle-class man. He was a landholder, he was independent, he was successful. He was the typical American citizen. The old farmer was father to the best blood of America. His sons and his sons' sons have answered to the roll call of our country's warriors, statesmen, writers, captains of industry.

Can the new farmer maintain the same relative social status? And if he can, is he to be an aristocrat, a landlord, a captain of industry, and to bear rule over the mossback? And is the tribe of mossbacks destined to increase and become a caste of permanent tenants or peasants? Is the future American farmer to be the typical new farmer of the present, or are we traveling toward a social condition in which the tillers of the soil 
will be underlings? Is there coming a time when the "man with the hoe" will be the true picture of the American farmer, with a low standard of living, without ideals, without a chance for progress?

We must eliminate the mossback. It is to be done largely by education and by coöperation. There must be a campaign for rural progress. There must be a union of the country school teacher, of the agricultural college professor, of the rural pastor, of the country editor, with the farmers themselves, for the production of an increased crop of new farmers. Anything that makes farm life more worth living, anything that banishes rural isolation, anything that dignifies the business of farming and makes it more prosperous, anything that broadens the farmer's horizon, anything that gives him a greater grasp of the rural movement, anything that makes him a better citizen, a better business man, or a better man, means the passing of the mossback. 


\section{IX}

\section{THE NEW CALL TO THE FARM* \\ T. Bayard Colins}

"BACK to the soil" was never a more attractive proposition and never so worthy of being heeded as during these opening years of the twentieth century. It is true that social economists have often uttered this cry because they believed, and rightly, that the overcrowded condition of cities could be relieved, to the immense advantage of everybody concerned, if the congested population found in sections of these human hives could be induced to leave their crowded quarters and become tillers of the soil. The advocates of the doctrine have had in mind a more decent and desirable condition for the objects of their solicitude-a place where they could develop a physical, social, and moral life superior to that which is possible to them in their present place of abode. The cry with which this opens, however, is not uttered especially to a crowded urban population. It is uttered to all men-to the inhabitants of every city, of whatever magnitude; to the dwellers in villages and hamlets, and to those who are already on the land, that they may be contented to remain there. It is uttered to the dissatisfied of every condition of life, or to those who ought to be dissatisfied. It is the

*From "The New Agriculture," by permission of the publishers, Munn and Company. 
cry, not of social economists only, not only of preachers, teachers, and statesmen, as distinguished from politicians, but of seers, of men who look into the future and see the good things that are there and the better things that are coming.

We are at the beginning of an era wonderful in the annals of agriculture; an era in which experiment and foresight and skill and invention and learning will transmute, as never before, the labor bestowed upon the land into wealth and health and happiness and length of days; an era of progress and development as wonderful as any that has hitherto astounded the world in other departments of investigation and endeavor, in which agriculture will, for progress, take her stand side by side with the industry of shipbuilding, for instance, which has within a comparatively few years reduced the time for crossing the Atlantic from three months to less than twice that many days, and increased the carrying capacity of single vessels from a few hundreds to many thousands of tons; by the side of railroading in which speed and safety and capacity has, in each succeeding year, laughed at the impossibilities of the year just gone; by the side of electrical development which, from a meager beginning of a generation ago, now renders us speechless in the presence of its phenomena of light and heat and power, and other manifestations still more subtle and marvelous.

In agriculture, the great mass of mankind have not looked upon intelligence and mental training as of especial value. Too many have thought of farmers as men "whose talk was of oxen and whose employment was in their labors"; have thought of those "labors" as 
being drudgery for the most part, and of financial returns so meager as to render farming utterly unattractive to any active man's contemplation. "By and by," said a philosopher of the last generation, "by and by it will be generally realized that few men live, or have lived, who could not find scope for all their intellect on a two-hundred-acre farm." Two score years have not yet gone since those words were uttered. 'To-day they are fulfilled. It is now generally known that agriculture offers an immense field for investigation and development by strictly scientific methods. Men of large business experience are going into it, and well-to-do professional men and merchants are taking it up as a feature of their summer life, finding in serious contact with the soil a worthy exercise of their highest faculties, and reaping from their labor a delightful experience of things brought to pass. Those who are already on the farm have come to realize that the best mental equipment is none too good for the tillers of the soil. They have demanded schools and colleges and courses of instruction for themselves and their sons which shall fit them to make of the farm a plant for the scientific and skilful production of all that it will yield. Statesmen and educators inculcated and fostered the same idea. Washington, a practical farmer, whose technical education was probably second to that of no man of his time in America, repeatedly brought to the attention of Congress the importance of providing adequate educational facilities and other encouragements in agriculture. Partly out of these recommendations, but more immediately out of the seed distribution originated in the Department of State during the Presidency of John 
Quincy Adams, sprang the United States Department of Agriculture, which in our day has attained such immense proportions, and the work of which is of such incalculable profit and importance. The different states of the Union, seeing the importance of technical training in the farming community, have provided colleges for this purpose, which now dot the land in all its sections. These schools are surrounded with ample farms in which practical demonstration goes hand in hand with the theories taught and the facts acquired in the classroom; they are provided with improved buildings, in many cases ideally adapted to the purposes for which they were constructed; they are granted large means for the prosecution of their work; they are equipped with precise instruments and all paraphernalia requisite for the successful prosecution of scientific investigation; and they are manned by scholarly and competent men who are imbued with the importance and the possibilities of their position.

The progress in other lines of human activity has had its influence upon agriculture. If men have found secrets in the sea and in the stars and in the ether which fills the interstices between the atoms of the air as water might fill the space in a barrel of buliets, the soil also has been searched for its mysteries, and is being made to yield them, too, in a truly wonderful manner. Lands which were not only thought worthless, but which were really so, are now made to bloom and blossom as the rose. Roads which were almost always bad, and at times impassable and considered impracticable of improvement, are now transformed by the magic of mind and muscle into highways of profit and delight. Frost.s 


\section{THE NEW CALL TO THE FARM 105}

are defied by new varieties of fruits and grain which live and thrive and mature into money where their predecessors wilted and died under the blighting breath of a providence which they could not withstand, to the discouragement, and sometimes to the despair, of the husbandman. The cactus, that abundant but useless growth of the desert, has but recently been rendered a delicious fruit capable of being grown throughout the length and breadth of the continent, and not only has the noxious herb been transformed into a valuable food for man and beast, but the same skill and scientific treatment which has been efficacious for this amazing transformation has also removed the spines, those needles which formerly covered it and rendered it so difficult to handle. What has been done with the cactus is the adumbration and prophecy of what is, one might almost say, becoming general in the realm of agriculture. Already the secdless apple and the pitless plum and the stingless bee have been attained. Fruits have been developed for which a name had to be inventedthe tangelo, for instance, which Adam did not find in all his rounds in the Garden of Eden, and which nature never produced till a wizard of agriculture, Webber, waved his wand over the fruit trees of his farm and bid the thing appear. Burbank has more than doubled the size of various fruits and flowers and esculent roots, and within a considerable range finds himself able to change the colors of nature almost at will. Under his manipulation the white blackberry is now an accomplished fact, and he tells us that he will give us a blue rose as soon as he can spare the time to coax it into being. And we must remember that it is only recently that he has been given 
the means and assistance that the dignity of his work deserves. It may not be said that Burbank is at the beginning of his career, but it is certain that the work which he has pointed out the way to perform will be carried forward by a great number of men, and that agriculture is but entering upon an era of development which will be as surprising as it will be profitable. Already the agricultural colleges of this and foreign lands and our own and foreign Agricultural Departments through their various experiment stations are working along these and other original lines, and the wonderful, the helpful, and the profitable are being brought to light every day. The pests of his plants and the diseases of his animals which were once the terror of the farmer are now so subject to control and cure as to give him little more than passing concern. Information is now available regarding probable weather conditions which subserve both his convenience and his profit. Eighty millions of people in this country alone are backing the work of the Weather Bureau which sends its forecasts to the furthermost sections of the country, and rural deliveries and country telephone lines carry to millions of farmers these predictions, 85 per cent. of which come true. Our own Weather Bureau and those of other countries are studying climatic and weather conditions with an intelligence and enthusiasm never before displayed. The reasons for drouth and flood are being pried into with the same persistence that physicians seek for the germ of a deadly disease, and the origin and prognosis of a hot wind will yet be as accurately determined as that of a fever. The upper air is being explored, and men are already knocking at 
the home of the storm with the view of learning the secrets that lie hidden there. There are conservative data for believing that in the not distant future scientific forecasts of the weather will reach within 5 per cent. of absolute accuracy and that they will be made for at least a season, and perhaps a year, in advance. What will it mean when the Government foretells for our farmers, witl $\mathbf{9 5}$ per cent. of fulfillment, for three months in advance, whether, in a given locality, the season is going to be early or late, hot or cold, wet or dry?

Starch is now increased in corn and potatoes at will, sugar in beets and cane, and gluten in wheat. If the eggs froin your poultry are too small for your liking they may be increased in size, and if there is not enough nitrogen in your soil you may sow it broadcast with bacteria at four cents an acre and these microscopic organisms will extract the needed element from the air and feed it to your plants. Is your land an alkali desert, you may obtain seeds and plants which will thrive even there and return you a profitable crop. Not only is drainage appreciated and applied to an extent never before attempted in this country, but drouth is being circumvented and defied, until, all in all, the uncertainties of the agriculturist are fewer than those of almost any other independent avocation.

It is freely admitted that the farmer's life still involves much hard labor and anxious care; that the elements may be against him, and that in one evil hour he may see the well-directed toil of months swept away; that his animals are subject to ills which his most assiduous care will not cure; insects and micro- 
organisms may blight and destroy his various growths of grain and fruit and root and deprive him, not only of his hope of abundance, but even of the most meager return for his labor. Men of wide observation and experience strongly advise against undertaking the vocation of the farmer without at least $\$ 500$ of capital to begin with, and this would secm to be little cnough, but the day when a man might begin without a penny and yet succeed has by no means gone by. Doubtless, under such circumstances, success is more readily reached in some parts of the country than in others. Seven years ago there entered one of the counties of west-central Georgia a young man who said he was from Indiana. He was very poorly dressed, and his few belongings he carried on a stick over his shoulder. He never vouchsafed much information regarding himself, more than that he had come down on foot-his appearance indicated it - and that he had stopped there simply because he liked the country. He worked for a nurseryman during the first winter for his board and lodging. The next spring he was given a pittance for helping to put in the crops. Later he assisted in the cultivation of a neighboring farm, and so efficient did he prove that the whole county soon learned of his presence. He made a hand in the corn-pulling and the cotton-picking, and later found work with a ginner. During his first year he had been looked upon with some suspicion; but so scrupulously had he conducted himself and so industrious and intelligent had he shown himself, that this feeling in regard to him was gradually disarmed. He applied for the position of teacher in the district school and got it. The term lasted six weeks, and he was three 
months in collecting his pay. He married the daughter of the best educated man in the county, a preacher, and with his young wife, he settled upon a run-down rented firm. To-day he owns a hundred and forty acres of fertile land without a dollar of indebtedness, and is looked upon as one of the most prosperous and respected men in his section of the state.

These results may doubtless be duplicated, but only by the same factors of character, industry, and intelligence. If a young man begins his married life without other means than those with which nature has endowed himself and his helpmeet-a good, clear mind and muscular arms-he must expect years of struggle, of frugality, of resolute, persistent industry before he can find an assured and ample income, seasons of ease and the surroundings of comparative luxury. On the farm much of the work is rugged and some of it repulsive. $\mathrm{He}$ will see other men no brighter, no more able than he - merchants, manufacturers, professional men making money with apparent rapidity and ease while his savings are meager and hard earned. He must be moved by none of these things. He is not striving for another's success, but for his own.

And there will, of course, be failures. The incompetent, the shiftless, the indolent will fail. Those to whom farm life in general is distasteful, who do not like its solitude and who do not love nature, who can find no delight in growing things and in the marvelous processes of season and soil and seed-to such the farm would be a weariness not to be endured and they had better seek a livelihood elsewhere.

But even as we write the elements are being foretold, 
and as we shall see there are other means at the farmer's command for his protection against unfavorable atmospheric conditions, so that less and less are blizzard and flood and drouth to hazard the rewards of his toil. If it is suggested that labor on the land is sometimes repulsive, we recall that the work of some of the professions is equally so-the physician, the nurse, the soldier, for instance. As for the difficulties that beset him in the diseases which afflict his cattle and his crops, these are yielding to the same applications of intelligence that are proving so efficacious in the treatment of the various diseases to which human flesh is heir. It is the fact of modern science successfully combating the discouraging and destructive factors in the farmer's occupation that gives vitality and persuasive power to the cry of the new gospel of agriculture, "Back to the soil."

But aside from the fair promises and growing certainties of the future in agriculture, there is no other calling in which success is anything like so nearly certain as in this. Our most reliable statisticians estimated that ninety-five men failed where five succeeded in the pursuit of traffic and trade. This estimate may possibly be too high, but probably it is close to the facts. Failures in these walks of life are so frequent and constant that they would seem tragic but for the fact that for every man who fails another immediately takes his place, so that the wreckage is continually removed from view and the frightful accumulation of it is prevented from becoming an object of our contemplation. If a dozen men attempt to do business in merchandise and make money in a community which can support only three, it is certain that nine out of the twelve will fail. 


\section{THE NEW CALL TO THE FARM 111}

There will be a period of fierce competition, more or less prolonged by the staying qualities of the men, their financial resources and power of will, but in the end nine men will fail and must fail. But you may double the number of farmers in any community whatsoever without dooming one of them to failure or appreciably affecting the profits which any one of them may reap as the reward of his toil. If the entire body of business and professional men who, in their present pursuits, are barely maintaining an existence-and there are thousands of them-should betake themselves to the soil tomorrow, the calling of agriculture would not be less profitable to those already engaged in it, while the entire population of the country would doubtless be greatly blessed and benefited. A competent business man or a wide-awake professional man may, by no fault of his own, be starved out of a given locality, but probably no one ever heard of an intelligent, energetic, and frugal farmer who failed to make a comfortable living; and, unless disabled by disease or accident, such factors have usually secured for him who exercised them an independent income, albeit, perhaps, a modest one, before age and decrepitude deprived him of his ability to labor.

To whatever extent false ideals may have driven out the true in other avenues of life, however widely money and power may have come to be accepted as the most desirable things in the world, and however high the social standing attained and maintained by those who in the pursuit of these things have perjured themselves and robbed and ruined their fellows under forms of law whereby they are saved from the arrest, trial, and im- 
prisonment which they so justly deserve, the foundations of God stand sure, and when truth is lost and honor dies the man is dead. The young doctor must have bread and is often tempted to the practice of a quackery he despises, and which at the beginning must be loathsome to him. Later in life, when the habit has become second nature, it is not bread, but money, more money, which constrains him, and thus his character may become crystallized into a hateful form. The same process may operate in the lawyer. To the first "dirty" professional job, he may drive himself against all his finer feelings. It may seem to him a necessity that he do "this thing." The second job will be less distasteful, thougn it may be equally "dirty," and in this manner may he also be led to part with his priceless heritage of honor. These observations are true to a larger or less extent of every line of gainful endeavor, with but one exception. Where they occur some men yield not at all, some yield reluctantly, and still others are made ready by heredity to perform the ignoble and the mean; but the agriculturist, so far as lis dealing is with the soil, is subject to none of these temptations. Here integrity -absolute honesty-is his sole reliance. He deals here with Nature and her laws direct, and she is to be neither cheated nor befooled. "Whatsoever a man soweth, that shall he also reap," while true of all men eventually, is obviously and evidently true for the husbandman at once. When he seeks to dispose of that which he has harvested, when he ceases from the strict work of the agriculturist and becomes a tradesman, there may then come the temptation to trickery; but so long as his dealings are with the soil, instead of offering the slightest induce- 
ment to substitute one thing for another that he may reap an unearned advantage, he finds that the behests and encouragements of Nature are all and always on the side of that which is recognized in the last analysis to be most worthy in man-truth, righteousness, and rectitude.

There is probably no other calling which is so conducive of thoroughgoing manliness as that of farming. Nobody expects the farmer to cringe or try to curry favor. In other words, he is, and is recognized to be, the overlord of his own life. He is never tempted to hide his opinions in the hope of more successfully dealing with his fellow men, nor is he fearful that, if outspoken, he may discount his prospects of prosperity. He may be orthodox or heterodox as to his religion: Republican, Democrat, Prohibitionist, or Socialist as to his politics: he may hold and teach absolutely any sane conviction at which he has arrived, but neither Nature with whom he deals on the one hand, nor the markets with which he has to do on the other, will take the slightest cognizance of any of these things. Nature asks only that he be intelligent and industrious; and the markets only that his offerings be of intrinsic value. Agriculture is rapidly coming to be one of the few callings in which the individual man may be himself, think and express his own thoughts, carry out his own policies, shape his own life, and wield with his might all the powers that he feels lie latent within him. In almost every other vocation in life the man is hampered and hindered and perhaps denied the exercise of his most profound convictions. If the place he occupies is an humble one, so much the worse; but even though he occupy an exalted position 
which carries with it large remuneration, he finds always in attempting to carry out his policies, however vital he may feel these policies to be, that there are other men, equals, in the employ of the same company, superiors, possibly, who must be consulted and argued with; that often his desires, his strong convictions even, must be shaped and shorn, and not unfrequently that they are entirely aborted. Jealousies are ever present to defeat his ends and embitter his life. Presidents and vicepresidents of great corporations are often under the restraint of influential stockholders. In political life it is even worse. High officers, governors of states, and mayors of great cities must frequently be deaf to the reasonable complaints of a long-suffering public, stifling at the same time their own personal convictions, and be blind to the misdeeds of the heads of departments who are ostensibly subject to, but are in fact contemptuously independent of, the chief executive. He must all too frequently grovel to his political boss and stand before the people as in the plentitude of power while submitting to the most humiliating dictation from the rear. Who shall say to the farmer, "Plant this field with corn" when in his judgment it should be planted with some other grain, or should not be planted at all? Who may dictate to him in any other particular? He may be proudly aware that no one expects him to confess any creed or maintain any view that is not in accordance with his deepest convictions. Nor has he to yield to the opinions or to defer to the prejudices or placate the jealousies of any man or of any set of men, save only as the spirit of a broad humanity may lead him in the paths of peace. His tolerance and self-restraint may 
be exercised without the sacrifice of a jot or tittle of his self-respect, without the impairment of his dignity $\mathrm{or}^{\circ}$ the deprivation of the consciousness that he is essentially a gentleman.

There is not a section of the broad land which does not to-day offer its own particular inducements to the agriculturist. The middle North, while still wonderfully attractive, no longer holds a monopoly of good things, cither in lands or produce. There are farming opportunities in the East which are as attractive to-day as the West offered twenty-five years ago. The South is a veritable Promised Land. The stories of the Far West and Northwest seem romantic in spite of their known truth and soberness.

It is the new era in agriculture that has rendered possible the reaping from the farms of this country the unthinkable sum of six and one half billions of dollars within the year. These profits, even distributed throughout the farming population, are rapidly making for a condition of well-being unsurpassed by any other class of the citizenship. The social life of the farm is immeasurably more attractive than ever before, and the improved school facilities, the labor-saving machinery, the rural delivery of mails, the fine roads, the county and inter-county telephone lines are daily adding to the enticing features of the farmer's life. 


\section{$\mathrm{X}$}

\section{THE PROBLEMS OF PROGRESS *}

\section{Kenyon L. Butterfield}

IT is impossible to acquire a keen and permanent interest in the rural problem unless one first of all is cognizant of its significance. And lack of knowledge at this point may in part account for the fact already alluded to that in America the farm problem has not been adequately studied. So stupendous has been the development of our manufacturing industries, so marvelous the growth of our urban population, so pressing the questions raised by modern city life, that the social and economic interests of the American farmer have, as a rule, received minor consideration. We are impressed with the rise of cities like Chicago, forgetting for the moment that half of the American people still live under rural conditions. We are perplexed by the labor wars that are waged about us, for the time unmindful that one third of the workers of this country make their living immediately from the soil. We are astounded, and perhaps alarmed, at the great centralization of capital, possibly not realizing that the capital invested in agriculture in the United States nearly equals the combined capital invested in the manufacturing and railway industries. But if we pause to consider the

*From "Chapters in Rural Progress," by permission of the publishers, University of Chicago Press. 
scope and nature of the economic and social interests involved, we cannot avoid the conclusion that the farm problem is worthy of serious thought from students of our national welfare.

We are aware that agriculture does not hold the same relative rank among our industries that it did in former years, and that our city population has increased far more rapidly than has our rural population. We do not ignore the fact that urban industries are developing more rapidly than is agriculture, nor deny the seriousness of the actual depletion of rural population, and even of community decadence, in some portions of the Union. But these facts merely add to the importance of the farm question. And it should not be forgotten that there has been a large and constant growth both of our agricultural wealth and of our rural population. During the last half-century there was a gain of 500 per cent. in the value of farm property, while the nonurban population increased 250 per cent. Agriculture has been one of the chief elements of America's industrial greatness, it is still our dominant economic interest, and it will long remain at least a leading industry. The people of the farm have furnished a sturdy citizenship and have been the primary source of much of our best leadership in political, business, and professional life. For an indefinite future, a large proportion of the American people will continue to live in a rural environment.

Current agricultural discussion would lead us to think that the farm problem is largely one of technique. The possibilities of the agricultural industry, in the light of applied science, emphasize the need of the 
farmer for more complete knowledge of soil and plant and animal, and for increased proficiency in utilizing this knowledge to secure greater production at less cost. This is a fundamental need. It lies at the basis of success in farming. But it is not the farm problem.

Business skill must be added, business methods enforced. The farmer must be not only a more skilful produce-grower, but also a keener produce-seller. But the moment we enter the realm of the market we step outside the individualistic aspect of the problem as embodied in the current doctrine of technical agricultural teaching, and are forced to consider the social aspect as emphasized, first of all, in the economic category of price. Here we find many factors-transportation cost, general market conditions at home and abroad, the status of other industries, and even legislative activities. The farm problem becomes an industrial question, not solely one of technical and business skill. Moreover, the problem is one of a successful industry as a whole, not merely the personal successes of even a respectable number of individual farmers. The farming class must progress as a unit.

But have we yet reached the heart of the question? Is the farm problem one of technique plus business skill, plus these broad economic considerations? Is it not perfectly possible that agriculture as an industry may remain in a fairly satisfactory condition, and yet the farming class fail to maintain its status in the general social order? Is it not, for instance, quite within the bounds of probability to imagine a good degree of economic strength in the agricultural industry existing side by side with either a peasant régime or a landlord- 
and-tenant system? Yet would we expect from either system the same social fruitage that has been harvested from our American yeomanry?

We conclude, then, that the farm problem consists in maintaining upon our farms a class of people who have succeeded in procuring for themselves the highest possible class status, not only in the industrial, but in the political and the social order-a relative status, moreover, that is measured by the demands of American ideals. The farm problem thus connects itself with the whole question of democratic civilization. This is not mere platitude. For we cannot properly judge the significance and the relation of the different industrial activities of our farmers, and especially the value of the various social agencies for rural betterment, except by the standard of class status. It is here that we seem to find the only satisfactory philosophy of rural progress.

We would not for a moment discredit the fundamental importance of movements that have for their purpose the improved technical skill of our farmers, better business management of the farm, and wiser study and control of market conditions. Indeed, we would call attention to the fact that social institutions are absolutely necessary means of securing these essential factors of industrial success. In the solution of the farm problem we must deliberately invoke the influence of quickened means of communication, of coöperation among farmers, of various means of education, and possibly even of religious institutions, to stimulate and direct industrial activity. What needs present emphasis is the fact that there is a definite, real, social end to be 
held in view as the goal of rural endeavor. The highest possible social status for the farming class is that end.

We may now, as briefly as possible, describe some of the difficulties that lie in the path of the farmers in their ambition to attain greater class efficiency and larger class influence, and some of the means at hand for minimizing the difficulties. A complete discussion of the farm problem should, of course, include thorough consideration of the technical, the business, and the economic questions implied by the struggle for industrial success; for industrial success is prerequisite to the achievement of the greatest social power of the farming class. But we shall consider only the social aspects of the problem.

Perhaps the one great underlying social difficulty among American farmers is their comparatively isolated mode of life. The farmer's family is isolated from other families. A small city of perhaps twenty thousand population will contain from four hundred to six hundred families per square mile, whereas a typical agricultural community in a prosperous agricultural state will hardly average more than ten families per square mile. The farming class is isolated from other classes. Farmers, of course, mingle considerably in a business and political way with the men of their trading town and county seat; but, broadly speaking, farmers do not associate freely with people living under urban conditions and possessing other than the rural point of view. It would be venturesome to suggest very definite generalizations with respect to the precise influence of these conditions, because, so far as the writer is aware, the psychology of isolation has not been worked out. 
But two or three conclusions seem to be admissible, and for that matter rather generally accepted.

The well-known conservatism of the farming class is doubtless largely due to class isolation. Habits, ideas, traditions, and ideals have long life in the rural community. Changes come slowly. There is a tendency to tread the well-worn paths. The farmer does not easily keep in touch with rapid modern development, unless the movements or methods directly affect him. Physical agencies which improve social conditions, such as electric lights, telephones, and pavements, come to the city first. The atmosphere of the country speaks peace and quiet. Nature's routine of sunshine and storm, of summer and winter, encourages routine and repetition in the man who works with her.

A complement of this rural conservatism, which at first thought seems a paradox, but which probably grows out of these same conditions of isolation, is the intense radicalism of a rural community when once it breaks away from its moorings. Many farmers are unduly suspicious of other's' motives; yet the same people often succumb to the wiles of the charlatan, whether medical or political. Farmers are usually conservative in politics and intensely loyal to party; but the Populist movement indicates the tendency to extremes when the old allegiance is left behind. Old methods of farming may be found alongside ill-considered attempts to raise new crops or to utilize untried machines.

Other effects of rural isolation are seen in a class provincialism that is hard to eradicate, and in the development of minds less alert to seize business advantages and less far-sighted than are developed by the 
intense industrial life of the town. There is time to brood over wrongs, real and imaginary. Personal prejudices often grow to be rank and coarse-fibered. Neighborhood feuds are not uncommon and are often virulent. Leadership is made difficult and sometimes impossible. It is easy to fall into personal habits that may mark off the farmer from other classes of similar intelligence, and that bar him from his rightful social place.

It would, however, be distinctly unfair to the farm community if we did not emphasize some of the advantages that grow out of the rural mode of life. Farmers have time to think, and the typical American farmer is a man who has thought much and often deeply. A spirit of sturdy independence is generated, and freedom of will and of action is encouraged. Family life is nowhere so educative as in the country. The whole family coöperates for common ends, and in its individual members are bred the qualities of industry, patience, and perseverance. The manual work of the schools is but a makeshift for the old-fashioned training of the country-grown boy. Country life is an admirable preparation for the modern industrial and professional career.

Nevertheless, rural isolation is a real evil. Presentday living is so distinctively social, progress is so dependent upon social agencies, social development is so rapid, that if the farmer is to keep his status he must be fully in step with the rest of the army. He must secure the social viewpoint. The disadvantages of rural isolation are largely in the realm of the social relations, its advantages mostly on the individual and 
moral side. Farm life makes a strong individual; it is a serious menace to the achievement of class power.

A cure for isolation sometimes suggested is the gathering of the farmers into villages. This remedy, however, is of doubtful value. In the first place, the scheme is not immediately practicable. About three and one half billions of dollars are now invested in farm buildings, and it will require some motive more powerful than that inspired by academic logic to transfer, even gradually, this investment to village groups. Moreover, it is possible to dispute the desirability of the remedy. The farm village at best must be a mere hamlet. It can secure for the farmer very few of the urban advantages he may want, except that of permitting closer daily intercourse between families. And it is questionable if the petty society of such a village can compensate for the freedom and purity of rural family life now existing. It may even be asserted with some degree of positiveness that the small village, on the moral and intellectual sides, is distinctly inferior to the isolated farm home.

At the present time rural isolation in America is being overcome by the development of better means of communication among farmers who still live on their farms. So successful are these means of communication proving that we cannot avoid the conclusion that herein lies the remedy. Improved wagon roads, the rural free mail delivery, the farm telephone, trolley lines through country districts, are bringing about a positive revolution in country living. They are curing the evils of isolation, without in the slightest degree robbing the farm of its manifest advantages for family life. The 
farmers are being welded into a more compact society. They are being nurtured to greater alertness of mind, to greater keenness of observation, and the foundations are being laid for vastly enlarged social activities. The problem now is to extend these advantages to every rural community-in itself a task of huge proportions. If this can be done and isolation can be reduced to a minimum, the solution of all the other rural social problems will become vastly easier.

Organization is one of the pressing social problems that American farmers have to face. The importance of the question is intrinsic, because of the general social necessity for coöperation which characterizes modern life. Society is becoming consciously self-directive. The immediate phase of this growing self-direction lies in the attempts of various social groups to organize their powers for group advantage. And if, as seems probable, this group activity is to remain a dominant feature of social progress, even in a fairly coherent society, it is manifest that there will result more or less of competition among groups.

The farming class, if at all ambitious for group influence, can hardly avoid this tendency to organization. Farmers, indeed more than any other class, need to organize. Their isolation makes thorough organization especially imperative. And the argument for coöperation gains force from the fact that relatively the agricultural population is declining. In the old days farmers ruled because of mere mass. That is no longer possible. The naïve statement that "farmers must organize because other classes are organizing" is really good social philosophy. 
In the group competition just referred to there is a tendency for class interests to be put above general social welfare. This is a danger to be avoided in organization, not an argument against it. So the farmers' organization should be guarded, at this point, by adherence to the principle that organization must not only develop class power, but must be so directed as to permit the farmers to lend the full strength of their class to general social progress.

Organization thus becomes a test of class efficiency, and consequently a prerequisite for solving the farm problem. Can the farming class secure and maintain a fairly complete organization? Can it develop efficient leaders? Can it announce, in sound terms, its proposed group policy? Can it lend the group influence to genuine social progress? If so, the organization of farmers becomes a movement of preëminent importance.

Organization, moreover, is a powerful educational force. It arouses discussion of fundamental questions, diffuses knowledge, gives practice in public affairs, trains individuals in executive work, and in fine, stimulates, as nothing else can, a class which is in special need of social incentive.

Organization is, however, difficult of accomplishment. While it would take us too far aficld to discuss the history of farmers' organizations in America, we may briefly suggest some of the difficultics involved. For forty years the question has been a prominent one among the farmers, and these years have seen the rise and decline of several large associations. There have been apparently two great factors contributing to the downfall of these organizations. The first was a mis- 
apprehension, on the part of the farmers, of the feasibil. ity of organizing themselves as a political phalanx; the second, a sentimental belief in the possibilities of business coöperation among farmers, more especially in lines outside their vocation. There is no place for class politics in America. There are some things legislation cannot cure. There are serious limitations to coöperative endeavor. It took many hard experiences for our farmers to learn these truths. But back of all lie some inherent difficulties, as, for instance, the number of people involved, their isolation, sectional interests, ingrained habits of independert action, of individual initiative, of suspicion of others' motives. There is often lack of penspective, and unwillingness to invest in a procedure that does not promise immediate returns. The mere fact of failure has discredited the organization idea. There is lack of leadership; for the farm industry, while it often produces men of strong mind, keen perception, resolute will, does not, as a rule, develop executive capacity for large enterprises.

It is frequently asserted that farmers are the only class that has not organized. This is not strictly true. The difficulties enumerated are real difficulties and have seriously retarded farm organization. But if the progress made is not satisfactory, it is at least encouraging. On the purely business side, over five thousand coöperative societies among American farmers have been reported. In coöperative buying of supplies, coöperative selling of products, and coöperative insurance, the volume of transactions reaches large figures. A host of societies of a purely educational nature exists among stock-breeders, fruit-growers, dairymen. It is 
true that no one general organization of farmers, embracing a large proportion of the class, has as yet been perfected. The nearest approach to it is the Grange, which, contrary to a popular notion, is in a prosperous condition, with a really large influence upon the social, financial, educational, and legislative interests of the farming class. It has had a steady growth during the past ten years, and is a quiet but powerful factor in rural progress. The Grange is perhaps too conservative in its administrative policy. It has not at least succeeded in converting to its fold the farmers of the great Mississippi Valley. But it has workable machinery, it disavows partisan politics and selfish class interests, and it subordinates financial benefits, while emphasizing educational and broadly political advantages. It seems fair to interpret the principles of the Grange as wholly in line with the premise of this paper, that the farmers need to preserve their status, politically, industrially, and socially, and that organization is one of the fundamental methods they must use. The Grange, therefore, deserves to succeed, and indeed is succeeding.

The field of agricultural organization is an extensive one. But if the farm problem is to be solved satisfactorily, the American farmers must first secure reasonably complete organization.

It is hardly necessary to assert that the education of that portion of the American people who live upon the land involves a question of the greatest significance. The subject naturally divides itself into two phases, one of which may be designated as rural education proper, the other as agricultural education. Rural 
education has to do with the education of people, more especially of the young, who live under rural conditions; agricultural cducation aims to prepare men and women for the specific rocation of agriculture. The rural school typifies the first; the agricultural school the second. Rural education is but a section of the general school question; agricultural education is a branch of technical training. These two phases of the education of the farm population meet at many points, they must work in harmony, and together they form a distinct educational problem.

The serious difficulties in the rural school question are perhaps three: first, to secure a modern school, in efficiency somewhat comparable to the town school, without unduly increasing the school tax; second, so to enrich the curriculum and so to expand the functions of the school that the school shall become a vital and coherent part of the community life, on the one hand translating the rural environment into terms of character and mental efficiency, and on the other hand serving perfectly as a stepping-stone to the city schools and to urban careers; third, to provide adequate highschool facilities in the rural community.

The centralization of district schools and the transportation of pupils will probably prove to be more nearly a solution of all these difficulties than will any other one scheme. The plan permits the payment of higher wages for teachers and ought to secure better instruction; it permits the employment of special teachers, as for nature-study or agriculture; it increases the efficiency of superintendence; it costs but little, if any, more than the district system; it leaves 


\section{THE PROBLEMS OF PROGRESS}

the school amid rural surroundings, while introducing into the schoolroom itself a larger volume, so to speak, of world-atmosphere; it contains possibilities for community service; it can easily be expanded into a high school of reputable grade.

There are two dangers, both somewhat grave, likely to arise from an urgent campaign for centralization. Even if the movement makes as great progress as could reasonably be expected, for a generation to come a large share, if not a major portion, of rural pupils will still be taught in the small, isolated, district school; there is danger that this district school may be neglected. Moreover, increased school machinery always invites undue reliance upon machine-like methods. Centralization permits, but does not guarantee, greater efficiency. A system like this one must be vitalized by corstant and close touch with the life and needs and aspirations of the rural community itself.

Whenever centralization is not adopted, the consolidation of two or three schools-a modified form of centralization-may prove helpful. Where the district school still persists, there are one or two imperative requirements. Teachers must have considerably higher wages and longer tenure. There must be more efficient supervision. The state must assist in supporting the school, although only in part. The small schools must be correlated with some form of high school. The last point is of great importance because of the comparative absence in country communities of opportunity near at hand for good high-school training.

Agricultural education is distinctively technical, not in the restricted sense of mere technique, or even of 
applied science, but in the sense that it must be frankly vocational. It has to do with the preparation of men and women for the business of farming and for life in the rural community.

Agricultural education should begin in the primary school. In this school the point of view, however, should be broadly pedagogical rather than immediately vocational. Fortunately, the wise teaching of nature-study, the training of pupils to know and to love nature, the constant illustrations from the rural environment, the continual appeal to personal observation and experience, absolute loyalty to the farm point of view, are not only sound pedagogy, but form the best possible background for future vocational study. Whether we call this early work "nature-study" or call it "agriculture" matters less than that the fundamental principle be recognized. It must first of all educate. The greatest difficulty in introducing such work into the primary school is to secure properly equipped teachers.

Perhaps the most stupendous undertaking in agricultural education is the adequate development of secondary education in agriculture. The overwhelming majority of young people who secure any agricultural schooling whatever must get it in institutions that academically are of secondary grade. This is a huge task. If developed to supply existing needs, it will call for an enormous expenditure of money and for the most careful planning. From the teaching viewpoint it is a difficult problem. Modern agriculture is based upon the sciences; it will not do, therefore, to establish schools in the mere art of farming. But these agri- 
cultural high schools must deal with pupils who are comparatively immature, and who almost invariably have had no preparation in science. Nor should the courses at these schools be ultra-technical. They are to prepare men and women for life on the farm-men and women who are to lead in rural development, and who nust get some inkling at least of the real farm question and its solution. The agricultural school, therefore, presents a problem of great difficulty.

A perennial question in agricultural education is: What is the function of the agricultural college? We have not time to trace the history of these colleges, nor to elaborate the various views relative to their mission. But'let us for a moment discuss their proper function in the light of the proposition that the preservation of the farmers' status is the real farm problem; for the college can be justified only as it finds its place among the social agencies helpful in the solution of the farm question.

In so far as the agricultural college, through its experiment station or otherwise, is an organ of research, it should carry its investigations into the economic and sociological fields, as well as pursue experiments in soil fertility and animal nutrition.

In the teaching of students, the agricultural college will continue the important work of training men for agricultural research, agricultural teaching, and expert supervision of various agricultural enterprises. But the college should put renewed emphasis upon its ability to send well-trained men to the farms, there to live their lives, there to find their careers, and there to lead in the movements for rural progress. A decade ago it 
was not easy to find colleges which believed that this could be done, and some agricultural educators have even disavowed such a purpose as a proper object of the colleges. But the strongest agricultural colleges today have pride in just such a purpose. And why not? We not only need men thus trained as leaders in every rural community, but, if the farming business cannot be made to offer a career to a reasonable number of collegetrained men, it is a sure sign that only by the most herculean efforts can the farmers maintain their status as a class. If agriculture must be turned over wholly to the untrained and to the half-trained, if it cannot satisfy the ambition of strong, well-educated men and women, its future, from the social point of view, is indeed gloomy.

The present-day course of study in the agricultural college does not, however, fully meet this demand for rural leadership. The farm problem has been regarded as a technical question, and a technical training has been offered the student. The agricultural college, therefore, needs "socializing." Agricultural economics and rural sociology should occupy a large place in the curriculum. The men who go from the college to the farm should appreciate the significance of the agricultural question, and should be trained to organize their forces for genuine rural progress. The college should, as far as possible, become the leader in the whole movement for solving the farm problem.

The farm home has not come in for its share of attention in existing schemes of agricultural education. The kitchen and the dining-room have as much to gain from science as have the dairy and the orchard. The 
inspiration of vocational knowledge must be the possession of her who is the entrepreneur of the family, the home-maker. The agricultural colleges through their departments of domestic science-better, of "homemaking"-should inaugurate a comprehensive movement for carrying to the farm home a larger measure of the advantages which modern science is showering upon humanity.

The agricultural college must also lead in a more adequate development of extension teaching. Magnificent work has already been done through farmers' institutes, reading courses, coöperative experiments, demonstrations, and correspondence. But the field is so immense, the number of people involved so enormous, the difficulties of reaching them so many, that it offers a genuine problem, and one of peculiar significance, not only because of the generally recognized need of adult education, but also because of the isolation of the farmers.

It should be said that in no line of rural betterment has so much progress been made in America as in agricultural education. Merely to describe the work that is being done through nature-study and agriculture in the public schools, through agricultural schools, through our magnificent agricultural colleges, through farmers' institutes, and especially through the experiment stations and the Federal Department of Agriculture in agricultural research and in the distribution of the best agricultural information-merely to inventory these movements properly would take the time available for this discussion. What has been said relative to agricultural education is less in way of criticism of existing: 
methods than in way of suggestion as to fundamental needs.

Wide generalizations as to the exact moral situation in the rural community are impossible. Conditions have not been adequately studied. It is probably safe to say that the country environment is extremely favorable for pure family life, for temperance, and for bodily and mental health. To picture the country a paradise is, however, mere silliness. There are in the country, as elsewhere, evidences of vulgarity in language, of coarseness in thought, of social impurity, of dishonesty in business. There is room in the country for all the ethical teaching that can be given.

Nor is it easy to discuss the country church question. Conditions vary in different parts of the Union, and no careful study has been made of the problem. As a general proposition, it may be said that there are too many churches in the country, and that these are illy supported. Consequently, they have in many cases inferior ministers. Sectarianism is probably more divisive than in the city, not only because of the natural conservatism of the people and a natural disinclination to change their views, but because sectarian quarrels are perhaps more easily fomented and less easily harmonized than anywhere else. Moreover, in the city a person can usually find a denomination to his liking. In the country, even with the present overchurched condition, this is difficult.

The ideal solution of the country church problem is to have in each rural community one strong church adequately supported, properly equipped, ministered to by an able man-a church which leads in community 
service. The path to the realization of such an ideal is rough and thorny. Church federation, however, promises large results in this direction and should be especially encouraged.

Whatever outward form the solution of the country church question may take, there seem to be several general principles involved in a satisfactory attempt to meet the issue. In the first place, the country church offers a problem by itself, socially considered. Methods successful in the city may not succed in the country. The country church question must then be studied thoroughly and on the ground.

Again, the same principle of financial aid to be utilized in the case of the schools must be invoked here. The wealth of the whole church must contribute to the support of the church everywhere. The strong must help the weak. The city must help the country. But this aid must be given by coöperation, not by condescension. The demand cannot be met by home missionary effort nor by church-building contributions; the principle goes far deeper than that. Some device must be secured which binds together the whole church, along denominational lines if must be, for a full development of church work in every community in the land.

Furthermore, there is supreme necessity for adding dignity to the country parish. Too often at present the rural parish is regarded either as a convenient laboratory for the clerical novice, or as an asylum for the decrepit or inefficient. The country parish must be a parish for our ablest and strongest. The ministry of the most Christlike must be to the hill-towns of Galilee as well as to Jerusalem. 
There is still another truth that the country church cannot afford to ignore. The rural church question is peculiarly interwoven with the industrial and social problems of the farm. A declining agriculture cannot foster a growing church. An active church can render especially strong service to a farm community, in its influence upon the religious life, the home life, the educational life, the social life, and even upon the industrial life. Nowhere else are these various phases of society's activities so fully members one of another as in the country. The country church should coöperate with other rural social agencies. This means that the country pastor should assume a certain leadership in movements for rural progress. He is splendidly fitted, by the nature of his work and by his position in the community, to coöperate with earnest farmers for the social and economic, as well as the moral and spiritual, upbuilding of the farm community. But he must know the farm problem. Here is an opportunity for theological seminaries: let them make rural sociology a required subject. And, better, here is a magnificent field of labor for the right kind of young men. The country pastorate may thus prove to be, as it ought to be, a place of honor and rare privilege. In any event, the country church, to render its proper service, not alone must minister to the individual soul, but must throw itself into the struggle for rural betterment, must help solve the farm problem.

The suggestion that the country church should ally itself with other agencies of rural progress may be carried a step further. Rural social forces should be federated. The object of such federation is to emphasize 
the real nature of the farm problem, to interest many people in its solution, and to secure the coopperation of the various rural social agencies, each of which has its sphere, but also its limitations. The method of federation is to bring together, for conference and for active work, farmers-especially representatives of farmers' organizations, agricultural educators, rural school-teachers and supervisors, country clergymen, country editors; in fact, all who have a genuine interest in the farm problem. Thus will come clearer views of the questions at issue, broader plans for reform, greater incentive to action, and more rapid progress.

In this brief analysis of the social problems of American farmers it has been possible merely to outline those aspects of the subject that seem to be fundamental. It is hoped that the importance of each problem has been duly emphasized, that the wisest methods of progress have been indicated, and that the relation of the various social agencies to the main question has been clearly brought out. Let us leave the subject by emphasizing once more the character of the ultimate farm problem. This problem may be stated more concretely, if not more accurately, than was done at the opening of the paper, by saying that the ideal of rural betterment is to preserve upon our farms the typical American farmer. The American farmer has been essentially a middle-class man. It is this type we must maintain. Agriculture must be made to yield returns in wealth, in opportunity, in contentment, in social position, sufficient to attract and to hold to it a class of intelligent, educated American citizens. This is an end vital to the preservation of American democratic 
ideals. It is a result that will not achieve itself ; social agencies must be invoked for its accomplishment. It demands the intelligent and earnest coöperation of all who love the soil and who seek America's permanent welfare. 


\section{XI}

\section{THE NATURE OF THE PROBLEM*}

\section{Liberty H. Bailey}

IF THE betterment of rural conditions is a process of evolution, then all persons who are to be concerned in the evolution must take active part in it if they are to enjoy the benefits of the progress; and I like to think that each person will enjoy these benefits in about the proportion that he actively participates in the work of reconstruction. That is to say, we all bear a natural responsibility, as citizens, to forward the rural status as well as the urban status; and this responsibility rests specially on all those who are near the problem or are a part of it. The countryman must not be one of a recipient or receptive class, but he must himself promptly help and coöperate to solve the rural problems and to discharge his full obligations to society.

Even a farm is not a private business in the sense that it should be absolved of responsibility to society and be outside all regulations in the interest of society.

Schools, colleges, experiment stations, departments, and bureaus devoted to agriculture and country life are now many and they are increasing. They mark a distinct advance in the application of knowledge and teaching to the plain daily problems of the pcople.

* From "The Training of Farmers," by permission of the publishers, The Century Company. 
They are rapidly becoming the best expressions or the social responsibility of government. Their work is free of cost to individuals; and in this fact lies a danger, now becoming real, that their benefits will be accepted as a matter of course and of right, and that the individual will not contribute in return as much as he is under obligation to contribute or as will make the help that he receives of real value to him; for I assume that when a person receives personal help and encouragement from society (or government) he contracts an obligation to aid society and his fellow man. The institutions will render the best service when they help persons to help themselves and when they stimulate active local initiative on the part of those with whom they deal or work.

If the countryman is to be trained to the greatest advantage, it will not be enough merely to bring in things from the outside and present them to him. Farming is a local business. The farmer stands on the land. In a highly developed society, he does not sell his farm and move on as soon as fertility is in part exhausted. This being true, he must be reached in terms of his environment. He should be developed natively from his own standpoint and work; and all schools, all libraries, and organizations of whatever kind that would give the most help to the man on the land must begin with this point of view.

I will illustrate this by speaking of the current country movement to revive sports and games. More games and recreations are needed in the country as much as in the city. In fact, there may be greater need of them in the country than elsewhere. The tendency seems to be 
just now, however, to introduce old folk-games. WVe must remember that folk-games such as we are likely to introduce have been developed in other countries and in other times. They represent the life of other peoples. To a large extent they are love-making games. They are not adapted in most cases to our climate. To introduce them is merely to bring in another exotic factor and to develop a species of theatricals.

I would rather use good games that have come directly out of the land. Or if new games are wanted I should like to try to invent them, having in mind the real needs of a community. I suspect that suggestions of many good sports can be found in the open country, that might be capable of considerable extension and development, and be made a means not only of relaxation, but of real education. We need a broad constructive derelopment of rural recreation, but it should be evolved out of rural conditions and not transplanted from the city.

We are gradually evolving into a social conception of government, by which I mean that the inherent rights and welfare of all the citizens are to be recognized and safeguarded and that the whole body of citizens shall work together coöperatively for these common ends. Privilege and opportunity belong to every man, according to his ability and deserts. It is a common misapprehension that this gradually approaching social stage will eliminate individualism and that its methods will constitute a leveling process; but individualism and social solidarity are not at all antipodal.

Individuality and personality are much to be desired, and we are under obligation to see that they arc 
not lost in our progressing civilization. The farmer is the individualist. His isolation, and his ownership of land and of tools, make him so. He may lose his individualism when he attempts to dispose of his product, but he nevertheless retains his feeling of individuality and independence throughout life. He may even resent any inquiry into his welfare by government, even though it is apparent that the sole purpose of the inquiry is to aid him. We need to preserve and encourage the spirit of independence, at the same time that we forward the social cohesion and working together of farmers on all points of mutual or collective interest. The educational and other institutions should help to do these two things, - to assist the farmer to rely on himself and to be resourceful, and to encourage him to work with other farmers fol the purpose of increasing the profitableness of farming and of developing a good social life in rural communities.

It will be seen at once that this is not at all a question of "uplift," as this word is commonly understood. The rural question is broadly a problem of stimulation, redirection, and reconstruction.

Nor is it, therefore, merely a problem of technical agriculture as an occupation, although, of course, the whole rural condition rests on the agricultural condition. All citizenship must rest ultimately on occupation, for all good citizens must be workers of one kind or another, and there must be no parasitic class. The question directly concerns all persons who live in rural communities, whatever their occupation, and it concerns them in all their relations,-in relations to church, 
school, coöperation, organization, to politics and all public improvement, and in the general outlook on life and the attitude toward all matters that affect the general welfare.

It is not a problem merely of the thinly settled farming regions, but of the entire country outside distinctly urban influences, comprising hamlets, villages, and even small cities that sit in an agricultural region and are controlled by agricultural sentiment. To designate this extra-urban realm I have used, for several years, the terms "the open country," and this has now become current in this semi-technical or special signification.

Considered as a whole, the people of the open country have not yet arrived at a conception of a thoroughly social or coopperative society. The farming people have been obliged - and are still obliged-to give too great a proportion of their thought and energy merely to making a living. They have not entered on the social phase and they scarcely know what it means. They are tied to the daily routine both because they have not learned how to organize and conduct an agricultural business effectively, and because they are preyed upon and subjugated by interests that control distribution, exchange, and markets, and that divert or exploit the common resources of the earth.

The farmer must be aided in his business of farming, and the artificial hindrances that are not a part of this business must be removed or checked by government; then he must be made to feel that he is to give of his time and talent to the community. In the largest sense, no person is a good citizen, whether in country or town, 
who merely has good character and is passively inoffensive and is a "good neighbor." He must be actively interested in the public welfare, and be willing to put himself under the guidance of a good local leader, if he does not himself attain to leadership. 


\section{XII}

\section{THE MAN WHO WORKS WITH HIS HANDS *}

\section{Theodore Roosevelt}

As a people there is nothing in which we take a juster pride than our educational system. It is our boast that every boy or girl has the chance to get a school training; and we feel it is a prime national duty to furnish this training free, because only thereby can we secure the proper type of citizenship in the average American. Our public schools and our colleges have done their work well, and there is no class of our citizens deserving of heartier praise than the men and women who teach in them.

Nevertheless, for at least a generation we have been waking to the knowledge that there must be additional education beyond that provided in the public school as it is managed to-day. Our school system has hitherto been well-nigh wholly lacking on the side of industrial training, of the training which fits a man for the shop and the farm. This is a most serious lack, for no one can look at the peoples of mankind as they stand at present without realizing that industrial training is one of the most potent factors in national development. We of the United States must develop a system under which each individual citizen shall be trained so as to be

* An address delivered at the Semi-centennial of the Michigan Agricutural College, Friday afternoon, May 31 st, 1907. 
effective individually as an economic unit and fit to be organized with his fellows; so that he and they can work in efficient fashion together. This question is vital to our future progress, and public attention should be focused upon it. Surely it is eminently in accord with the principles of our democratic life that we should furnish the highest average industrial training for the ordinary skilled workman. But it is a curious thing that in industrial training we have tended to devote our energies to producing high-grade men at the top rather than in the ranks. Our engineering schools, for instance, compare favorably with the best in Europe, whereas we have done almost nothing to equip the private soldiers of the industrial army-the mechanic, the metal-worker, the carpenter. Indeed, too often our schools train away from the shop and the forge; and this fact, together with the abandonment of the old apprentice system, has resulted in such an absence of facilities for providing trained journeymen that in many of our trades almost all the recruits among the workmen are foreigners. Surely this means that there must be some systematic method provided for training young men in the trades, and that this must be coordinated with the public-school system. No industrial school can turn out a finished journeyman; but it can furnish the material out of which a finished journeyman can be made, just as an engineering school furnishes the training which enables its graduates speedily to become engineers.

We hear a great deal of the need of protecting our workingmen from competition with pauper labor. I have very little fear of the competition of pauper labor. 
The nations with pauper labor are not the formidable industrial competitors of this country. What the American workingman has to fear is the competition of the highly skilled workingman of the countries of greatest industrial efficiency. By the tariff and by our immigration laws we can always protect ourselves against the competition of pauper labor here at home; but when we contend for the markets of the world we can get no protection, and we shall then find that our most formidable competitors are the nations in which there is the most highly developed business ability, the most highly developed industrial skill; and these are the qualities which we must ourselves develop.

We have been fond as a nation of speaking of the dignity of labor, meaning thereby manual labor. Personally I don't think that we begin to understand what a high place manual labor should take; and it never can take this high place unless it offers scope for the best type of man. We have tended to regard education as a matter of the head only, and the result is that a great many of our people, themselves the sons of men who worked with their hands, seem to think that they rise in the world if they get into a position where they do no hard manual work whatever; where their hands will grow soft and their working-clothes will be kept clean. Such a conception is both false and mischievous. There are, of course, kinds of labor where the work must be purely mental, and there are other kinds of labor where, under existing conditions, very little demand indeed is made upon the mind, though I am glad to say that $I$ think the proportion of men engaged in this kind of work is diminishing. But in any healthy 
community, in any community with the great solid qualities which alone make a really great nation, the bulk of the people should do work which makes demands upon both the body and the mind. Progress cannot permanently consist in the abandonment of physical labor, but in the development of physical labor so that it shall represent more and more the work of the trained mind in the trained body. To provide such training, to encourage in every way the production of the men whom it alone can produce, is to show that as a nation we have a true conception of the dignity and importance of labor. The calling of the skilled tiller of the soil, the calling of the skilled mechanic, should alike be recognized as professions, just as emphatically as the callings of lawyer, of doctor, or banker, merchant, or clerk. The printer, the electrical worker, the house painter, the foundry man, should be trained just as carefully as the stenographer or the drug clerk. They should be trained alike in head and in hand. They should get over the idea that to earn twelve dollars a week and call it "salary" is better than to earn twentyfive dollars a week and call it "wages." The young man who has the courage and ability to refuse to enter the crowded field of the su-called professions and to take to constructive industry is almost sure of an ample reward in earnings, in health, in opportunity to marry early, and to establish a home with reasonable freedom from worry. We need the training, the manual dexterity, and industrial intelligence which can best be given in a good agricultural, or building, or textile, or watchmaking, or engraving, or mechanical school. It should be one of our prime objects to put the mechanic, the 
wage-worker who works with his hands, and who ought to work in a constantly larger degree with his head, on a higher plane of efficiency and reward, so as to increase his effectiveness in the economic world, and therefore the dignity, the remuneration, and the power of his position in the social world. To train boys and girls in merely literary accomplishments to the total exclusion of industrial, manual, and technical training tends to unfit them for industrial work; and in real life most work is industrial.

The problem of furnishing well-trained craftsmen, or rather journeymen fitted in the end to become such, is not simple-few problems are simple in the actual process of their solution-and much care and forethought and practical common-sense will be needed, in order to work it out in a fairly satisfactory manner. It should appeal to all our citizens. I am glad that socicties have already been formed to promote industrial education, and that their membership includes manufacturers and leaders of labor unions, educators and publicists, men of all conditions who are interested in education and in industry. It is such coöperation that offers most hope for a satisfactory solution of the question as to what is the best form of industrial school, as to the means by which it may be articulated with the public-school system, and as to the way to secure for the boys trained therein the opportunity to acquire in the industries the practical skill which alone can make them finished journeymen.

There is but one person whose welfare is as vital to the welfare of the whole country as is that of the wageworker who does manual labor, and that is the tiller of 
the soil-the farmer. If there is one lesson taught by history, it is that the permanent greatness of any state must ultimately depend more upon the character of its country population than upon anything else. No growth of cities, no growth of wealth, can make up for a loss in either the number or the character of the farming population. In the United States more than in almost any other country we should realize this and should prize our country population. When this nation began its independent existence it was as a nation of farmers. The towns were small and were for the most part near seacoast trading and fishing ports. The chief industry of the country was agriculture, and the ordinary citizen was in some way connected with it. In every great crisis of the past a peculiar dependence has had to be placed upon the farming population; and this dependence has hitherto been justified. But it cannot be justified in the future if agriculture is permitted to sink in the scale as compared with other employments. We cannot afford to lose that preëminently typical American, the farmer who owns his own farm. Yet it would be idle to deny that in the last halfcentury there has been in the eastern half of our country a falling off in the relative condition of the tillers of the soil, although signs are multiplying that the nation has waked up to the danger and is preparing to grapple effectively with it. East of the Mississippi and north of the Ohio and the Potomac there has been on the whole an actual shrinkage in the number of the farming population since the Civil War. In the states of this section there has been a growth of population-in some an enormous growth-but the growth has taken place 
in the cities, and especially in the larger cities. This has been due to certain economic factors, such as the extension of railloads, the development of machinery, and the openings for industrial success afforded by the unprecedented growth of cities. The increased facility of communication has resulted in the withdrawal from rural communities of most of the small, widely distributed manufacturing and commercial operations of former times, and the substitution therefor of the centralized commercial and manufacturing industries of the cities.

The chief off set to the various tendencies which have told against the farm has hitherto come in the rise of the physical sciences and their application to agricultural practices or to the rendering of country conditions more easy and pleasant. But these countervailing forces are as yet in their infancy. As compared with a few decades ago, the social or community life of country people in the East compares less well than it formerly did with that of the dwellers in cities. Many country communities have lost their social coherence, their sense of community interest. In such communities the country church, for instance, has gone backward, both as a social and a religious factor. Now, we cannot insist too strongly upon the fact that it is quite as unfortunate to have any social as any economic falling off. It would be a calamity to have our farms occupied by a lower type of people than the hardworking, self-respecting, independent, and essentially manly men and womanly women who have hitherto constituted the most typically American, and on the whole the most valuable element in our entire nation. Am- 
bitious native-born young men and women who now tend away from the farm must be brought back to it, and therefore they must have social as well as economic opportunities. Everything should be done to encourage the growth in the open farming country of such institutional and social movements as will meet the demand of the best type of farmers. There should be libraries, assembly halls, social organizations of all kinds. The school building and the teacher in the school building should, throughout the country districts, be of the very highest type, able to fit the boys and girls not merely to live but thoroughly to enjoy and to make the most of the country. The country church must be revived. All kinds of agencies, from rural free delivery to the bicycle and tine telephone, should be utilized to the utmost; good roads should be favored; everything should be done to make it easier for the farmer to lead the most active and effective intellectual, political, and economic life.

There are regions of large extent where all this, or most of this, has already been realized; and while this is perhaps especially true of great tracts of farming country west of the Mississippi, with some of which I have a fairly intimate personal knowledge, it is no less true of other great tracts of country east of the Mississippi. In these regions the church and the school flourish as never before; there is a more successful and more varied farming industry; the social advantages and opportunities are greater than ever before: life is fuller, happier, more useful; and though the work is more effective than ever, and in a way quite as hard, it is carried on so as to give more scope for well-used 
leisure. My plea is that we shall all try to make more nearly universal the conditions that now obtain in the most favored localities.

Nothing in the way of scientific work can ever take the place of business management on a farm. We ought all of us to teach ourselves as much as possible; but we can also all of us learn from others; and the farmer can best learn how to manage his farm even better than he now does by practice, under intelligent supervision on his own soil in such a way as to increase his income. This is the kind of teaching which has been carried on in Texas, Louisiana, and Arkansas by Doctor Knapp, of the National Department of Agriculture. But much has been accomplished by the growth of what is broadly designated as agricultural science. This has been developed with remarkable rapidity during the last quarter of a century, and the benefit to agriculture has been great. As was inevitable, there was much error and much repetition of work in the early application of money to the needs of agricultural colleges and experiment stations alike by the nation and the several states. Much has been accomplished; but much more can be accomplished in the future. The prime need must always be for real research, resulting in scientific conclusions of proved soundness. Both the farmer and the legislature must be aware of invariably demanding immediate returns from investments in research efforts. It is probably one of our faults as a nation that we are too impatient to wait a sufficient length of time to accomplish the best results; and in agriculture effective research often, although not always, involves slow and long-continued effort if the results are to be trust- 
worthy. While applied science in agriculture as elsewhere must be judged largely from the standpoint of its actual return in dollars, yet the farmers no more than anyone else can afford to ignore the large results that can be enjoyed because of broader knowledge. The farmer must prepare for using the knowledge that can be obtained through agricultural colleges by insisting upon a constantly more practical curriculum in the schools in which his children are taught. He must not lose his independence, his initiative, his rugged selfsufficiency; and yet he must learn to work in the heartiest coöperation with his fellows.

The corner stones of our unexampled prosperity are, on the one hand, the production of raw material, and its manufacture and distribution on the other. These two great groups of subjects are represented in the national government principally by the Department of Agriculture and the Department of Commerce and Labor.* The production of raw material from the surface of the earth is the sphere in which the Department of Agriculture has hitherto achieved such notable results. Of all the executive departments there is no other, not even the Post-Office, which comes into more direct and beneficent contact with the daily life of the people than the Department of Agriculture, and none whose yield of practical benefits is greater in proportion to the public money expended.

But great as its services have been in the past, the Department of Agriculture has a still larger field of usefulness ahead. It has been dealing with growing crops. It must hereafter deal also with living men.

* In 1913 this Department was divided into the Department of Commerce and the Department of Labor.-The Editors. 
Hitherto agricultural research, instruction, and agitation have been directed almost exclusively toward the production of wealth from the soil. It is time to adopt in addition a new point of view. Hereafter another great task before the National Department of Agriculture and the similar agencies of the various states must be to foster agriculture for its social results, or, in other words, to assist in bringing about the best kind of life on the farm for the sake of producing the best kind of men. The government must recognize the far-reaching importance of the study and treatment of the problems of farm life, alike from the social and the economic standpoints; and the federal and state departments of agriculture should coöperate at every point.

The farm grows the raw material for the food and clothing of all our citizens; it supports directly almost half of them; and nearly half the children of the United States are born and brought up on farms. How can the life of the farm family be made less solitary, fuller of opportunity, freer from drudgery, more comfortable, happier, and more attractive? Such a result is most earnestly to be desired. How can life on the farm be kept on the highest level, and where it is not already on that level, be so improved, dignified, and brightened as to awaken and keep alive the pride and loyalty of the farmer's boys and girls, of the farmer's wife, and of the farmer himself? How can a compelling desire to live on the farm be aroused in the children that are born on the farm? All these questions are of vital importance, not only to the farmer, but to the whole nation; and the Department of Agriculture must do its share in answering them. 
The drift toward the city is largely determined by the superior social opportunities to be enjoyed there, by the greater vividness and movement of city life. Considered from the point of view of natural efficiency, the problem of the farm is as much a problem of attractiveness as it is a problem of prosperity. It has ceased to be merely a problem of growing wheat and corn and cattle. The problem of production has not ceased to be fundamental, but it is no longer final; just as learning to read and write and cipher are fundamental, but are no longer the final ends of education. We hope ultimately to double the average yield of wheat and corn per acre; it will be a great achievement; but it is even more important to double the desirability, comfort, and standing of the farmer's life.

We must consider, then, not merely how to produce, but also how production affects the producer. In the past we have given but scant attention to the social side of farm life. We should study much more closely than has yet been done the social organization of the country, and inquire whether its institutions are now really as useful to the farmer as they should be, or whether they should not be given a new direction and a new impulse, for no farmer's life should lie merely within the boundary of his farm. This study must be of the East and the West, the North and the South; for the needs vary from place to place.

First in importance, of course, comes the effort to secure the mastery of production. Great strides toward this end have already been taken over the larger part of the United States; much remains to be done, but much has been done; and the debt of the nation to the various 
agencies of agricultural improvement for so great an advance is not to be overstated. But we cannot halt here. The bencfits of high social organization include such advantages as ease of communication, better educational facilities, increased comfort of living, and those opportunities for social and intellectual life and intercourse, of special value to the young people and to the women, which are as yet chiefly to be had in centers of population. All of this must be brought within the reach of the farmers who live on the farms, of the men whose labor feeds and clothes the towns and cities.

Farmers must learn the vital need of coöperation with one another. Next to this comes coöperation with the government and the government can best give its aid through associations of farmers rather than through the individual farmer; for there is no greater agricultural problem than that of delivering to the farmer the large body of agricultural knowledge which has been accumulated by the national and state governments and by the agricultural colleges and schools. Nowhere has the government worked to better advantage than in the South, where the work done by the Department of Agriculture in connection with the cotton growers of the southwestern states has been phenomenal in its value. The farmers in the region affected by the boll weevil, in the course of the efforts to fight it, have succeeded in developing a most scientific husbandry, so that in many places the boll weevil became a blessing in disguise. Not only did the industry of farming become of very much greater economic value in its direct results, but it became immensely more interesting to thousands of families. The meetings at which 
the new subjects of interest were discussed grew to have a distinct social value, while with the farmers were joined the merchants and bankers of the neighborhood. It is needless to say that every such successful effort to organize the farmer gives a great stimulus to the admirable educational work which is being done in the southern states, as elsewhere, to prepare young people for an agricultural life. It is greatly to be wished that the communities whence these students are drawn and to which they either return or should return, could be coöperatively organized; that is, that associations of farmers could be organized, primarily for business purposes, but also with social ends in view. This would mean that the returned students from the institutions of technical learning would find their environment prepared to profit to the utmost by the improvements in technical methods which they had learned.

The people of our farming regions must be able to combine among themselves as the most efficient means of protecting their industry from the highly organized interests which now surround them on every side. A vast field is open for work by coöperative associations of farmers in dealing with the relation of the farm to transportation and to the distribution and manufacture of raw materials. It is only through such combination that American farmers can develop to the full their economic and social power. Combination of this kind has, in Denmark, for instance, resulted in bringing the people back to the land, and has enabled the Danish peasant to compete in extraordinary fashion, not only at home but in foreign countries, with all rivals. 
Agricultural colleges and farmers' institutes have done much in instruction and inspiration; they have stood for the nobility of labor and the necessity of keeping the muscles and the brain in training for industry. They have developed technical departments of high practical value. They seek to provide for the people on the farms an equipment so broad and thorough as to fit them for the highest requirements of our citizenship; so that they can establish and maintain country homes of the best type and create and sustain a country civilization more than equal to that of the city. The men they train must be able to meet the strongest business competition, at home or abroad, and they can do this only if they are trained, not alone in the various lines of husbandry, but in successful economic management. These colleges, like the state experiment stations, should carefully study and make known the needs of each section, and should try to provide remedies for what is wrong.

The education to be obtained in these colleges should create as intimate relationship as it is possible between the theory of learning and the facts of actual life. Educational establishments should produce highly trained scholars, of course; but in a country like ours, where the educational establishments are so numerous, it is folly to think that their main purpose is to produce these highly trained scholars. Without in the least disparaging scholarship and learning-on the contrary, while giving hearty and ungrudging admiration and support to the comparatively few whose primary work should be creative scholarship-it must be remembered that the ordinary graduate of our 
colleges should be and must be, primarily, a man and not a scholar. Education should not confine itself to books. It must train executive power and try to create that right public opinion which is the most potent factor in the proper solution of all political and social questions. Book-learning is very important, but it is by no means everything; and we shall never get the right idea of education until we definitely understand that a man may be well trained in book-learning and yet, in the proper sense of the word and for all practical purposes, be utterly uneducated; while a man of comparatively little book-learning may, nevertheless, in essentials have a good education.

It is true that agriculture in the United States has reached a very high level of prosperity; but we cannot afford to disregard the signs which teach us that there are influences operating against the establishment or retention of our country life upon a really sound basis. The overextensive and wasteful cultivation of pioneer days must stop and give place to a more economical system. Not only the physical but the ethical needs of the people of the country districts must be considered. In our country life there must be social and intellectual advantages as well as a fair standard of physical comfort. There must be in the country, as in the town, a multiplication of movements for intellectual advancement and social betterment. We must try to raise the average of farm life, and we must also try to develop it so that it shall offer exceptional chances for the exceptional man.

Of course the essential things after all are those which concern all of us men and women, no matter 


\section{MAN WHO WORKS WITH HIS HANDS 161}

whether we live in the town or in the country, and no matter what our occupations may be. The root problems are much the same for all of us, widely though they may differ in outward manifestation. The most important conditions that tell for happiness within the home are the same for the town and the country; and the relations between employer and employee are not always satisfactory on the farm any more than in the factory. All over the country there is a constant complaint of paucity of farm labor. Without attempting to go into all the features of this question I would like to point out that you can never get the right kind, the best kind, of labor if you offer employment only for a few months, for no man worth anything will permanently accept a system which leaves him in idleness for half the year.

And most important of all, I want to say a special word on behalf of the one who is too often the very hardest worked laborer on the farm-the farmer's wife. Reform, like charity, while it should not end at home, should certainly begin there; and the man, whether he lives on a farm or in a town, who is anxious to see better social and economic conditions prevail through the country at large, should be exceedingly careful that they prevail first as regards his own womankind. I emphatically believe that for the great majority of women the really indispensable industry in which they should engage is the industry of the home. There are exceptions of course; but exactly as the first duty of the normal man is the duty of being the home maker, so the first duty of the normal woman is to be the home keeper; and exactly as no other learning is as important 
for the average man as the learning which will teach him how to make his livelihood, so no other learning is as important for the average woman as the learning which will make her a good housewife and mother. But this does not mean that she should be an overworked drudge. I have hearty sympathy with the movement to better the condition of the average tiller of the soil, of the average wage-worker, and I have an even heartier sympathy and applause for the movement which is to better the condition of their respective wives. There is plenty that is hard and rough and disagreeable in the necessary work of actual life; and under the best circumstances, and no matter how tender and considerate the husband, the wife will have at least her full share of work and worry and anxiety; but if the man is worth his salt he will try to take as much as possible of the burden off the shoulders of his helpmate. There is nothing Utopian in the movement; all that is necessary is to strive toward raising the average, both of men and women, to the level on which the highest type of family now stands, among American farmers, among American skilled mechanics, among American citizens generally; for in all the world there is no better and healthier home life, no finer factory of individual character, nothing more representative of what is best and most characteristic in American life than that which exists in the higher type of American family, and this higher type of family is to be found everywhere among us, and is the property of no special group of citizens.

The best crop is the crop of children; the best products of the farm are the men and women raised thereon; and the most instructive and practical treatises 


\section{MAN WHO WORKS WITH HIS HANDS 168}

on farming, necessary though they be, are no more necessary than the books which teach us our duty to our neighbor, and above all to the neighbor who is of our own household. You young men and women of the agricultural and industrial colleges and schools must have some time for light reading; and there is some light reading quite as useful as heavy reading, provided, of course, that you do not read in a spirit of mere vacuity. Aside from the great classics, and thinking only of the many healthy and stimulating books of the day, it is easy to pick out many which can really serve as tracts, because they possess what many avowed tracts and treatises do not, the prime quality of being interesting. You will learn the root principles of selfhelp and helpfulness toward others from "Mrs. Wiggs of the Cabbage Patch," just as much as from any formal treatise on charity; you will learn as much sound social and industrial doctrine from Octave Thanet's stories of farmers and wage-workers as from avowed sociological and economic studies; and I cordially recommend the first chapter of "Aunt Jane of Kentucky" for use as a tract in all families where the men folks tend to selfish or thoughtless or overbearing disregard of the rights of their womankind.

Do not misunderstand me. I have not the slightest sympathy with those hysterical and foolish creatures who wish women to attain to easy lives by shirking their duties. I have as hearty a contempt for the woman who shirks her duty of bearing and rearing the children, of doing her full housewife's work, as I have for the man who is an idler, who shirks his duty of earning a living for himself and for his children, or who 
is selfish or brutal toward his wife and children. I believe in the happiness that comes from the performance of duty, not from the avoidance of duty. But I believe also in trying, each of us, as strength is given us, to bear one another's burdens; and this especially in our own homes. No outside training, no coöperation, no government aid or direction can take the place of a strong and upright character; of goodness of heart combined with clearness of head, and that strength and toughness of fiber necessary to wring success from a rough workaday world. Nothing outside of home can take the place of home. The school is an invaluable adjunct to the home, but it is a wretched substitute for it. The family relation is the most fundamental, the most important of all relations. No leader in church or state, in science or art or industry, however great his achievement, takes the place of the mothers, "who are the first of sovereigns and the most divine of priests." 


\section{XIII \\ THE COUNTRY GIRL *}

\section{Martha Foote Crow}

The clarion of the country life movement has by this time been blown with such loudness and insistence that no hearing ear in our land can have escaped its announcement. The distant echoes of brutal warfare have not drowned it: above all possible rude and cruel sounds this peaceful piping still makes itself heard.

It has reached the ears of the farmer and has stirred his mind and heart to look his problems in the face, to realize their gigantic implications, and to shoulder the responsibility of their solution. It has penetrated to the thoughts of teachers and educators everywhere and awakened them to the necessities of the minute, so that they have declared that the countryside must have educational schemes adapted to the needs of the countryside people, and that they must have teachers whose heads are not in the clouds. It has aroused easy-going preachers in the midst of their comfortable dreams and has caused here and there one among them to bestir himself and to make hitherto unheard-of claims as to what the church might do-if it would-for the betterment of country life.

And all of these have given hints to philanthropists

* From "The American Country Girl," by Martha Foote Crow. By permission of the author and of the publishers, Frederick A. Stokes Company. 
and reformers, and these to organizations and societics; these again have suggested theories and projects to legislators, senators, and presidents; the snowball has been rolled larger and larger; commissions have sat, investigations have been made, documents have been attested, reports handed in, bills drafted and, what is better, passed by courageous legislatures; so that now great schemes are being not only dreamed of, but put into actual fulfilment. Moreover, lecturers have talked and writers have issued bulletins and books, until there has accumulated a library of vast proportions on the many phases of duty, activity, and outlook that may be included under the title, "A Country Life Movement."

In all this stirring field of new interest, the farmer and his business hold the center of attention. Beside him, however, stands a dim little figure hitherto kept much in the background, the farmer's wife, who at last seems to be on the point of finding a voice also; for a chapter is now assigned to her in every book on rural conditions and a little corner under a scroll work design is given to her tatting and her chickens in the weekly farm paper. Cuddled about her are the children, and they, the little farm boys and girls, have now a book that has been written just about them alone-their psychology and their needs. Also, the tall, strong youth, her grown-up son, has his own paper as an acknowledged citizen of the rural commonwealth. But where is the tall young daughter, and where are the papers for her and the books about her needs? It seems that she has not yet found a voice. She has failed to impress the makers of books as a subject for 
description and investigation. In the nation-wide effort to find a solution to the great rural problems, the farmer is working heroically; the son is putting his shoulder to the wheel; the wife and mother is in sympathy with their efforts. Is the daughter not doing her share? Where is the Country Girl and what is happening in her department?

It is easier on the whole to discover the rural young man than to find the typical Country Girl. Since the days of Mother Eve the woman young and old has been adapting herself and readapting herself, until, after all these centuries of constant practice, she has become a past master in the art of adaption. Like the cat in the story of Alice, she disappears in the intricacy of the wilderness about her and nothing remains of her but a smile.

There are some perfectly sound reasons why American country girls as a class cannot be distinguished from other girls. Chief among these is the fact that no group of people in this country is to be distinguished as a class from any other group. It is one of the charms of life in this country that you never can place anybody. No one can distinguish between the shop girl and a lady of fashion; nor is any school teacher known by her poise, primness, or imperative gesture. The fashion paper, penetrating to the remotest dug-out, and the railway engine indulging us in our national passion for travel see to these things. Moreover, the pioneering period is still with us and the western nephews must visit the cousins in the old home in New Hampshire, while the aunts and uncles left behind must go out and see the new Nebraska or Wyoming lands 
on which the young folks have settled. We do not stay still long enough anywhere in the republic for a class of any sort to harden into recognizable form. New inhabitants may come here already hardened into the mold of some class; but they or their children usually soften soon into the quicksilver-like consistency of their surroundings.

There is also no subdividing of notions on the basis of residence, whether as townsman or as rural citizen. The wind bloweth where it listeth in this land. It whispers its free secrets into the ears of the citydweller in the flat and of the rural worker of the cornfield or the vine-screened kitchen. The rain also falls on the just and the unjust whether suburbanated or countrified. There is no rural mind in America. There has indeed been a great deal of pother of late over the virtue and temper of "rural-minded people."

This debate has been conscientiously made in the effort to discern reasons why commissions should sit on a rural problem. Reasons enough are discernible why commissions should sit, but they lie rather in the unrural mind of the rural people, as the words are generally understood, than in some supposed qualities imposed or produced in the life of sun and rain, in that vocation which is nearest to the creative activities of the Divine.

And if there is no rural mind, there is no distinctive rural personality. If the man that ought to exemplify it is found walking up Fifth Avenue or on Halstead Street or along El Camino Real, he cannot be discovered as a farmer. He may be discovered as an ignorant person, or he may be found to be a college-bred man; 
but in neither case would the fact be logically inclusive or uninclusive of his function as farmer.

The same is almost as exactly true for his wife and his daughter. If one should ask in any group of average people whether the farmer's daughter as they have known her is a poor little undeveloped child, silent and shy, or a hearty buxom lass, healthy and strong and up-to-date, some in the group would say the latter and some the former. Both varieties exist and can by searching be found along the countryside. But it is nothing essentially rural that has developed either the one set of characteristics or the other. To be convinced of this, one who knows this country well has but to read a book like "Folk of the Furrow," by Christopher Holdenby, a picture of rural life in England. In such a book as that one realizes the full meaning of the phrase, "the rural mind," and one sees how far the men and women that live on the farms in the United States have yet to go, how much they will have to coagulate, how many centuries they will have to sit still in their places with wax in their ears and weights on their eyelids, before they will have acquired psychological features such as Mr. Holdenby gives to the folk of the English furrow.

A traveler in the Old World frequently sees illustrations of this. For instance, in passing through some European picture gallery, he may meet a woman of extraordinary strength and beauty, dressed in a stylc representing the rural life in that vicinity. She will wear the peasant skirt and bodice, and will be without gloves or hat. A second look will reveal that the skirt is made of satin so stiff that it could stand alone; the 
velvet bodice will be covered with rich embroidery; and heavy chains of silver of quaint workmanship will suspend around the neck.

On inquiry one may learn that this stately woman was of what would be called in this country a farmer family, that had now become very wealthy; that she did not consider herself above her "class"would describe it-no, that she gloried in it instead. It was from preference only that she dressed in the fashion of that "class."

Now, whether desirable or not, such a thing as this would never be seen in America. No woman (unless it were a deaconess or a Salvation Army lassie or a nun) would pass through the general crowd showing her rank or profession in life by her style of dress. And that is how it happens that neither by hat nor by hatlessness would the country woman here make known her pride in the possession of acres or in her relation to that profession that forms the real basis of national prosperity. Hence no country girl counts such a pride among her inheritances. Therefore if it is not easy to find and understand the Country Girl as a type, it is not because she is consciously or unconsciously hiding herself away from us; she is not even sufficiently conscious of herself as a member of a social group to pose in the attitude of an interesting mystery. She is just a human being happening to live in the country (not always finding it the best place for her proper welfare), just a single one in the great shifting mass.

Although it may be difficult to find what we may think are typical examples of the Country Girl as a social group, yet certain it is that she exists. Of young 
women between the ages of fifteen and twenty-nine, there are in the United States six and a half million $(6,694,-$ 184 to be exact) who reside in the open country or in small villages. This we are assured is so by the latest Census Report.*

By starting a little further down in the scale of girlhood and advancing a trifle further into maturity this number could be doubled. It would be quite justifiable to do this, because some farmers' daughters become responsible for a considerable amount of labor value well before the age of fifteen; and on the other hand the energy of these young rural women is abundantly extended beyond the gateway of womanhood, far indeed into the period that used to be called old-maidism, but which is to be so designated no more; the breezy, executive, free-handed period when the country girl is of greatest use as a labor unit and gives herself without stint (and often without pay) to the welfare of the whole farmstead. The American Country Girl is not by any means behind her city sister in her ability to make the bounds of her youth elastic, though the girl on the farm may go at it in a somewhat different way. Then, perhaps, too, the word "youth" may, alas! have another connotation in the mind of one from what it has in the dreams of the other.

If we should, however, thus enlarge the scope of our inquiry, we should increase but not clarify our problems. Moreover, it is the Country Girl that interests us, the promise and hope of her dawn, the delicate, swiftly changing years of her growth, the miracle of her blossoming. There is something about the kaleidoscope of

* The figures here given are from the Census of 1910. 
her moods and the inconsistencies of her biography that fascinates us. The moment when she awakes, when the sparkle begins to show in her eyes, when we know that a conception of her mission and of her supreme value to life is beginning to glow before her imaginationthat is the crisis to work for and to be happy over when it comes. As for us, we ask no greater happiness than once or twice to catch a glimpse of that.

That great host of six million country girls is scattered far and wide; they are everywhere present. A certain number of millions of them are working industriously in myriads of unabandoned farms all over the Appalachian plateau, and on the wide prairies to the Rockies and beyond. In thousands of farmsteads they are helping their mothers wash dishes three times a day three hundred and sixty-five days in the year, not counting the steps as they go back and forth between dining-room and kitchen. They are carrying heavy pails of spring water into the house and throwing out big dishpanfuls of waste water, regardless of the strain in the small of the back. They are picking berries and canning them for the home table in the winter; they are raising tomatoes and canning them for the market; they are managing the younger children; they are baking and sewing and reading and singing; they are caring for chickens and for bees and for orphan lambs; they ride the rake and the disc-plow and sometimes join the round-up on the range. Moreover, they go to church and they go to town and they look forward to an ideal future just as other girls do. The Country Girl is a human being also.

It has been intimated that young women living on 
remote secluded farms have not, with all their singing, been always able to dispel the monotony of a thousand inevitable dishwashings a year; they are said nowadays to have opened their car to the lure of the town and to have started out, keeping step with their brothers, to join what some one has called, "the funeral procession of the nation" cityward. If we could, in fact, get them to confide in us, we should find that they have longings and aspirations, many of which are unsatisfied; and that is the reason why it seems to be high time for their voice to be heard.

Some of the younger farm women are showing themselves equal to the larger burdens in the business of agriculture. They are running their own farms in Michigan and their own automobiles in Kansas. They are taking up claims. They are developing them and proving up in the Dakotas and through Montana and Wyoming. From four to six in the morning they till an acre; then they ride twenty miles to the school and teach from nine to four; after that they ride back and work in their cornfields till the stars twinkle out. They stay alone in their shack and are happy and fearless and safe.

Moreover some thousands of the girls are laboriously teaching schools in thousands of one-room schoolhouses, where they provide almost one hundred per cent. of the common instruction for fifty per cent. of the population.

Besides this, there is no one of all the gainful occupations in which young women of this country engage which has not drawn upon the reservoir of country strength for supplies. Among those women black- 
smiths and engineers, those clerks, secretaries, librarians, and administrators, those lawyers, doctors, professors, writers, those nurses, settlement workers, investigators and other servants of the people in widely diverse fields, there are many whose clearness of eye and reserve of force have been developed in the wholesome conditions of the open country. The Country Girl has no reason to be ashamed of the part she has borne in the non-rural world. It has been said that about eighty per cent. of the names found in "Who's Who in America" represent an upbringing in the rural atmosphere. The proportion of women in this number or the special proportion of grown-up farm girls to be found among those women cannot be stated; but the number must be large enough to justify a belief that to spend a childhood in the open country or in the rural village will not, in the case of women any more than in the case of men, form an impassable barrier to eminence.

From this great rural reserve of initiating force, sane judgment, and spiritual drive have come, in fact, some of the most valued names in philanthropy and literature. Among them we find the leader of a great reform, Frances Willard; the inaugurator of a world-wide work of mercy, Clara Barton; the president of a great college, Alice E. Freeman; the wise helper of all who suffer under unjust conditions in city life, Jane Addams; and the writer of a book that has had a national and world-wide influence, Harriet Beecher Stowe.

It heartens us up a bit to name over examples like these. They give us a vista and a hope. But now and then there is a Country Girl who would rather have, say, a better pair of stilts over the morass or a stronger 
rope thrown to her across the quicksand, than a volume of "Who's Who" tossed carelessly to her in her difficulties. For all the country girls on their farms do not sing at their work. They are not idle, heaven knows! - but their work does not invariably inspire the appreciation it deserves.

Of course no one would wish to claim that the young woman in the farmstead is of more importance than other members of the home; but as a chain will break if one link fails, so the farmstead will be ruined if it lacks the coöperation of the daughter. She has, at least, a function all her own; and the happiness that comes through normal growth must be hers in order that she may fulfil her mission. The farmstead girl must take her place in the farmstead or the farmstead unit will lack one of its component parts and fall to pieces. It is her patriotic duty; it is her home and family duty; and it is her greatest happiness. The young woman on the farm must grow up with the idea that she is essential to the progress of country life and therefore of the national life and that a career is before her just as much as if she were aiming to be an artist or a writer or a missionary. This purpose makes her life worth while; she must conserve her health for this; she must develop her powers for this; she must train herself heroically for this. 

THE FARMER AS A MAN OF BUSINESS 



\section{XIV}

\section{BUSINESS METHODS IN FARMING *}

\section{Oscar H. Benson}

America is the land of farms, and agriculture is its most important and fundamental industry. All othes occupations must go back to the soil, either directly or indirectly, for their support, if not for their very existence. The success and welfare of every class of our population, therefore, depend on the business of farming.

The United States is especially favored in the fertility of its virgin soil, its vast areas of tillable land, and its wide ranges of climate adapted to the growing of many crops. America leads the world in agricultural opportunity. No other people possess the advantages and natural wealth that we have in our farms.

Yet the very fact that our soil is rich and our land plentiful contains an element of danger. For nature's kindness and prodigality have led us into carelessness in the use of this, the most important of our natural resources. We have been almost criminally wasteful of the fertility of our soil.

Our first care has been to get the largest possible returns out of a given amount of highly expensive labor -for land has been plentiful and cheap, while labor has

* From "Agriculture and the Farming Business," by Oscar H. Benson and George Herbert Betts. Copyright, 1917. Used by special permission of the publishers, The Bobbs-Merrill Company. 
been dear. In few regions have we learned the meaning of intensive farming such as must constantly be practised in most countries of Europe and Asia in order to feed the population.

When more food has seemed necessary for our everincreasing population, we have only "gone West" and opened up fields of virgin territory. Often this has been done after robbing the eastern or southern soil of most of its fertility. Here the older fields have been given over to idleness for the more promising fields of the West. During the last three hundred years of American history, we have been continually looking to the frontier states for farms and future homes. First, the white-covered "prairie schooners," and, later, the railway trains have carried a sturdy race of pioneers toward the setting sun and this country, the dream of plenty.

This constantly moving population has been the direct cause of the rapid settlement and development of many of our best agricultural sections. It has given us an enterprising and progressive farming population, -men and women consecrated to the cause of transforming wild prairies and untamed forests into fertile acres and productive fields. Everywhere they have gone we now find beautiful gardens, orchards, and homes as monuments to their endurance, industry, and persistence.

The frontiers of this nation, however, are fast becoming a thing of the past. Most of our best land has already been opened up to settlement and divided into farms. We now have under cultivation the larger part of the land available to feed our ever-increasing 
population. True, there are vast fields of our great plains and millions of acres of forest land yet to be reclaimed. All this, however, will have to be made productive at much greater expense of money and energy than was required for the earlier lands now occupied by the American farmers. Most of the land in order to be put under tillage will require permanent and costly systems of irrigation. Such regions will finally be reclaimed by science and good business management; for we need the land, and must have it. Both federal and state governments are even now doing all in their power to aid in its reclamation. But we should first of all conserve and use to the best advantage the land we now have under cultivation.

The tiller of the soil is one of our most important economic factors. On his success and prosperity the welfare of the nation depends. His intelligence and progress will have a far-reaching effect upon our entire industrial history, and will go far to determine our place among nations. We have no peasantry. American farmers, as a class, are intelligent, they are ambitious, they are men of affairs. The American farmer is not infrequently called upon to serve as state legislator, congressman, or senator. From his ranks we have taken governors and presidents.

In all American industries there have recently been great changes. Inventions, better education, and a new outlook upon life have led to prosperity; the farming business and this prosperity have worked toward greater efficiency. During the past generation, and especially during the past ten years, the entire face of the earth industrially has been making over 
very rapidly. New manufacturing machinery has been introduced, greater systems devised, the cost of production reduced and the amount increased.

Among all of our industries, however, none has experienced a greater growth and development than the business of farming. It is no longer to be classed as unskilled labor, a catch-all job for the man who cannot find an opening elsewhere. The farmer of to-day would find himself greatly handicapped if he should undertake to think and act in terms of the past. A generation ago one could find plenty of careless practitioners, but almost no practical scientists among our farmers; on the other hand, there were a considerable number known as agricultural theorists, but who knew little or nothing about real farm practice. Consequently, there developed misunderstanding between the practitioner and the scientist. They had very little of common interest.

The progressive farmers of to-day, however, are practical scientists; they know how to translate scientific information into common practice. To succeed in farming, one must understand the care of the soil and how to conserve it; he must be thoroughly informed in matters of fertilizing, systems of rotating crops and the tillage of various soils. Every farmer must be a business manager, salesman, bookkeeper, and an allaround man of ability and skill. In a measure, the farmer must be both a bacteriologist and an entomologist, for unless he knows how to combat the insect pests and plant diseases of growing crops, trees, and farm animals, he will sooner or later meet his Waterloo in the battle with these enemies. 
Scientific breeding of stock and the fitting of every farm enterprise into the farming business as a whole are of utmost importance. A man must understand markets and methods of marketing. The adjustment of time in the use of labor; machinery, animals, and acres, so as to secure a maximum return from a minimum investment, this is most imperative in these days of business competition and ever-increasing land and food values.

The home is the true center of all farm interests and activities. It is to build homes that we buy our farms, build up our enterprises and apply our best skill in labor. If the farm neglects the domestic life, the happiness and well-being of the family, if it forgets its obligations to the community, the church and state, not only the farm, but society in general surely will suffer the consequences. All of these relations and many others call for the greatest degree of intelligence, for good business.sense, and for constant fidelity to the cause of American rural life as well as all-around farm efficiency.

Recent years have shown increased and unusual interest on the part of the whole world in the business of farming. This is not merely philanthropic, nor is it a sentimental necessity. People in other occupations, particularly those in business and commerce, have come to appreciate that farming is the cconomic basis of every type of work and enterprise. All members of society to-day wish the farmer well, and are willing to advance his prosperity, not alone because they are interested in the farmer as a social equal and a fellow citizen, but because they recognize that they must ulti- 
mately go back to the tiller of the soil for food, shelter, and practically all the comforts of life. They want the farmer to raise larger and better crops, produce more and better stock, and himself be happy and prosperous because of the inevitable prosperity that it brings to all others.

At. the present time we are told that the American population is increasing many times faster than is the production of our food supplies. During the last twenty years the cost of living has practically doubled. If this continues for the next decade, it will be difficult to judge the economic and social consequences. It is, therefore, important that every acre of land in the United States be made increasingly efficient, to produce more and better food. And. this means intensive farming; but this does not necessarily bar extensive farming.

There is yet a large area of our land untouched by the hand of tillage. On these barren acres, which science and business enterprise will yet make fruitful, there is room for thousands of those who are now living in filth, poverty, and obscurity in the congested centers of our large cities. But they must be able to possess themselves of the promised land-they must be trained to the business of farming.

So also in the southern states, where the growing season is long, rainfall plentiful, and where every conceivable kind of food will grow and thrive, there is only a comparatively small percentage of the total area of the land under cultivation. When one travels over these areas of untilled acres which will surely one day be the garden spot of America, he cannot but feel that some very definite policy should be adopted toward 
offering to the millions of our poverty-stricken city dwellers a chance to work out their salvation and be better fed from the soil. But this cannot be done simply by transferring them from city to open country. They must first be educated in the science and practice of agriculture, stock-raising, and farm management, else they would suffer in the country as surely as in the city.

The new interest in agriculture has resulted in the organization of many agencies to help the farmer. The federal government is now spending millions of dollars every year in agricultural extension work, farm demonstrations, farm surveys, experimentation, and in scientific research in agriculture. New varieties of crops are being tested and new breeds of animals produced. Successful attempts are being made to control the ravages caused by insect and plant enemies of farm crops and animals, and many other lines of investigation pursued. Every state has its experiment station, its extension force and its college of agriculture, with an array of farm experts who are doing everything. in their power to advance the interests of agriculture and the farmer. The nation and the state join in employing farm.agents, trained in both practical and scientific agriculture, to work with the farmers in the solution of their immediate problems. Farm bulletins are being printed and distributed free of charge by the United States Department of Agriculture and the state agricultural colleges. Extension lectures and agricultural experts are going into every community, teaching the application of science to all crop and animal production. Various commercial organizations, bankers' associations and 
business men's clubs are everywhere contributing generously to the advancement of agricultural education and progress.

The farmers themselves are in most instances responding to their opportunities and endeavoring faithfully to meet the many new. problems that have been thrust upon them. Progressive farmers everywhere are eagerly studying the scientific investigations being made in the field of agriculture. They are reading the books and bulletins, attending the agricultural short courses at the state colleges, supporting farmers' institutes, studying stock and grain judging and in every way doing their best to place farming upon the scientific basis that our new conditions demand.

The business of farming to-day offers a career second to none to be found among the industrial or business vocations. It has opportunities for the man of intelligence and ambition. It requires and rewards initiative and enterprise. It demands and is willing to pay for the best intellect and industry that our country affords. The farmer will always be an important factor in American wealth and progress, and is destined to take still higher rank as a contributor to industrial and social welfare. 


\section{XV}

FARM MANAGEMENT-A NEW SCIENCE *

\section{W. J. Spilliman}

Agricultural science may be said to have had its beginning with the studies of Bousingault, the distinguished French scientist, who in the year 1804 began a series of experiments to determine the usefulness of certain chemical substances as sources of plant food. Enormous strides have been made since that time. A whole flock of sciences has grown up around agriculture as a center, and we now have numerous kinds of agricultural specialists. Some investigators limit themselves to the study of soils; others confine their attention to the growing of field crops; others to garden crops and fruits; some study only plant diseases; others the diseases of animals. The science of nutrition has become an important phase of agricultural science. We might go on enumerating dozens of specialties that now have their followers.

It was natural that these early investigators should attack the problems of farming from the standpoint of sciences in which they had had their training. Thus the chemist becomes interested in the application of his science to the problems of farming, and develops Agricultural Chemistry. The botanist becomes an agronomist-a man who specializes in growing crops.

* From Tractor Farming, April, 1919, by permission of the author and the International Harvester Company of America. 
Under the impulse of these specialists we developed the slogan: "He who grows two blades of grass where one grew before is a greater public benefactor than he who rules a city." The fact that the farmer who grew the two blades often got less for them than he formerly got for one seemed to be overlooked. Much emphasis was placed on the dignity of the farmers' calling, which was to "feed the world."

Finally there came along a man whose thinking was cut on the bias. He called attention to the fact that men had been farming for many thousand years before anyone ever thought of any kind of science. In fact, civilization began when men began to cultivate crops. The distinguished mark between the earliest civilized communities and the savage hordes that surrounded them was a settled agriculture. This man, whose mental pattern had been cut crosswise of the leather, insisted that during the thousands of years men had been farming they had learned much that had been handed down from father to son by tradition. He even went so far as to say that ninety per cent. of what we know about farming was derived from experience, the other ten per cent. from scientific investigation. He proposed that we take up the study of farm practice as a means of formulating the knowledge gained by practical farmers and too often lost again when the old experienced men passed out. He finally found an opportunity to make such studies and to train a lot of enthusiastic young men to do likewise.

But a very unexpected result came from these studies. They had not proceeded far when it became apparent that there lay hidden in the experience of practical 
farmers a new science that no one had ever recognized. This science was later named Farm Management. It deals with the principles involved in making farming profitable, as well as successful from the standpoint of feeding and clothing the world. Amongst European economists who have studied rural economics the idea seems to be quite firmly fixed that because the average small farm in Europe produces greater values per acre than large farms, it necessarily follows that all farms should be small. We look at this matter quite differently in America. We are not so much concerned about the return per acre. The point we emphasize is the return per man. If a farm family can make a better living on 100 acres from which they can secure a return of $\$ 20$ per acre than on 20 acres from which they get a return of $\$ 50$ per acre, then we advise the hundred-acre farm. We think it is better for the country as a whole to have farm families making $\$ 2,000$ than $\$ 1,000$ a year.

Perhaps the first important lesson learned from the new science of Farm Management was the fact that the doctrine of the "small farm well-tilled" is a fallacy. We have substituted for this doctrine the better one of "a good living and ten per cent." for every farm familyfive per cent. as interest on the investment and five per cent. as wages for labor and management on the part of the farm operator.

In every case where farm management surveys have been made, when the farms are divided into groups based on size of farm, and only farms of the same general type are considered, it was found that families on the smaller farms were not making an adequate living. In general 
the best results are secured when the farm is of such size and so organized that it will give full employment to two men, which is about the proper size to give an average farm family opportunity to utilize their full carning capacity without making themselves slaves to their work. In other words, the science of farm management has taught us that best results are secured all around on family farms.

Farm management investigators have developed simple methods of analyzing the business of a farm in such manner as to show the profit or loss from the year's operations. If the farm business is not too complex the farmer himself can fill in one of these "survey" blanks and find what his profit or loss for the year has been. He can do it in any case if he will keep a few simple records of his sales and purchases. By analyzing the business of a large number of farms in the same community it is easily possible to tell what types of farming are most profitable in that community. Not only that, but it is possible to tell what acreage of each of the leading crops should be grown on the average farm for best results. Thus, in Chester County, Pennsylvania, it was found that those farmers who had two years of corn in their rotation instead of one year made much more money. Those who grew no oats in this particular locality made more money than those who did. Those who had about forty to forty-five per cent. of their land in hay made more than those who had more or less hay acreage. These surveys have been of much help to the farmers in the regions where they have been made, and they should be made in every important agricultural region of the country every few 
years. They would help to keep agriculture on an even keel by showing when changes in cropping systems and kinds of live stock are needed, and what these changes should be.

It has, of course, always been known that farmers who keep their land fertile made more profit than those who let their land run down. But farm management surveys have given this fact more definite meaning. They show just how much a given increase in yield would add to the profit in farming. Sometimes it happens that profits can be increased much more rapidly by concentrating attention on something else than increased yield per acre. Thus the easiest way to increase profits on a given farm may be to increase or even to decrease the number or kind of dairy cows kept, to cut down the number of work horses required by making some insignificant change in the relative acreage of the crops grown, by introducing a tractor that will enable the operator to get his plowing done more promptly, by increasing or decreasing the number of hogs or steers fed, or in any one of a hundred other ways. In one case a careful study of a farm that was making no profit revealed the fact that it had the best rotation for its region; that its yields per acre were just about what they should be; that the number of cows and the quality of these cows were all that could be desired. The owner lived on the farm, but conducted a law business in a near-by town, and could not give the farm very close supervision. His foreman was an old man who had two sons and three sons-in-law, four of whom were already employed on this farm, and the old man was trying to make a place for the fifth, although 
the farm needed only two good men to keep it going in good shape. The labor bill ate up the profits. Had we not already studied the question of the amount of labor really required on similar farms in this region the real trouble on this farm would probably have been overlooked. In fact, one "expert" had already told the owner that the real solution to his troubles was that his cows were not good enough, while another had suggested that if he would substitute alfalfa for clover and timothy his troubles would disappear.

The science of farm management also deals with problems of farm equipment. One trouble we find with small farms is that they cannot afford to own the larger types of labor-saving machinery which they seriously need. Many farmers who keep four or more work horses have only two-horse implements. If they would equip their farms with a full set of four-horse implements they could save nearly half of what they now pay out to hired men, for fewer men could do the work.

Another very important lesson learned in farm management investigations is that the young fellow just starting out with very little capital can make about three times as much as a renter than he can as the owner of the land he tills. The reason for this is that with his small capital he can farm four or five times as much land as a tenant than his capital would permit him to own. It is only when he has enough ahead to make a first payment on a good-sized farm that it pays him to pass from tenant to owner. But the fact that farmers universally become owners just as soon as they are able to make a decent living on land of their own shows that there are compelling reasons for owning rather 
than renting land. This subject is too big to discuss fully here.

Perhaps the most important contribution the science of farm management has made to farming is in working out simple methods of getting at the cost of production on the farm. Heretofore many farmers have been growing wheat or keeping cows at a loss. The fact that these men could stay in business at all made some people believe they must be making a profit. But this is not true. We can all agree that farmers are entitled to wages and interest on their investment. But if a farmer gets two per cent. interest on a considerable investment, and fifty cents a day for his labor a good portion of the year, he can still live. This is just what wheat growers were doing when wheat was selling for eighty cents a bushel. It is also what milk producers were doing when butter was thirty cents a pound and milk three and one half cents a quart. Now that we can easily find what it costs to produce wheat or milk the public is beginning to wake up to the fact that farmers have not always been getting a square deal. The force of public opinion has compelled milk dealers in the big cities to pay prices that would at least return to the farmer his cost of production. The result is greatly increased prices for milk. With the knowledge now available to farmers they will no longer go ahead blindly producing food and clothing at prices that return them less than a fair rate of interest on their investment and less than fair wages for their labor.

The science of farm management has developed methods of finding what the manure of a farm animal is really worth to the farmer; how much a silo adds to the 
farm income; whether it pays best to feed steers or keep dairy cows; whether it pays best to have one acre or five acres of orchard; whether on the ordinary farm it is more profitable to keep 100 hens or 300 . It can be made to deliver answers to hundreds of other questions that were never raised at all until we began to study the factors that make for greatest profit in farming. This new science has been slow in making its way in the agricultural colleges. It has met with opposition in high places. But it is gradually winning its way, and before long will be taught in every school of agriculture in the land. When this is done farming will be a much more attractive calling than it is even now. Farmers will find their business more profitable. They will have more money with which to buy from those whose business is to supply what farmers need in their business. And the standard of living on the farm will be higher than it is under present conditions. 


\section{XVI}

\section{HOW THE GOVERNMENT WORKS WITH THE}

\section{FARMER *}

\section{David F. Houston}

IN THE field of agriculture there is much to be done. This fundamental part of the Nation's industrial life will not stand still. Constructive action must, of necessity, continue, and there will be need of very clear and unbiased thinking. We shall have our troubles. We shall be confronted with numerous proposals from the enthusiast with limited knowledge and less sense of direction. The tasks confronting us in agriculture are tasks not of reconstruction but rather of further construction, of selection, and emphasis. I am confident that the agriculture of the Nation is on substantially sound foundations and is developing in the right direction. Many experienced and disciplined minds and agencies in all parts of the country have zealously been stuying the problems for many years, with increasing effectiveness during the last generation, and it will surprise me if many novel steps of large proportions are not taken.

Farming, of course, must pay. There always will be farmers enough if the business of farming is made profitable and if the conditions of farm life are made

* From The American Review of Reviews, November, 1919, by permission. 
attractive and healthful. The farmer, as well as the industrial worker, is entitled to a living wage and a reasonable profit on the investment. He is entitled also to satisfactory educational opportunities for his children and to the benefits of modern medical science and sanitation. It is not the mission of the farmers simply to supply food to the consumers at prices which the latter desire to pay. This is not the test. It is no more the duty of the farmers to supply food on an unprofitable basis than it would be for the manufacturer to supply manufactured articles on an unprofitable basis. Each should want the other industry to prosper and the producers of all commodities to receive a fair price for what they produce.

Of course everything possible is being done to enable the farmer to produce more economically, so that if prices do fall he will not sustain a loss, or so great a loss. All the efforts of the Department of Agriculture and of the land-grant colleges have this aim. They are trying to bring about better methods of cultivation, better financing, better marketing, the elimination of plant and animal diseases and insect pests, and the better utilization of labor. Much has been done in this direction, and much more will be done as time passes.

Interest in land for homes and farms increases in the Nation as the population grows. It has become more marked as the area of public land suitable and available for agriculture has diminished. It is intensified by reason of the suggestion and desire that returned soldiers and others who may wish to secure farms shall have an opportunity to do so under suitable conditions. It finds expression, too, in discussions of 
the number of tenant farmers and in its meaning and significance.

That there is room in the Nation for many more people on farms is clear. The United States proper contains about 1,900,000,000 acres of land, of which an area of 1,140,000,000 acres, or 60 per cent., is tillable. Approximately $36 \%, 000,000$ acres, or 32 per cent., of this was planted in crops in 1918. In other words, for every 100 acres now tilled 300 acres may be utilized when the country is fully settled. Of course, much of the best land, especially that most easily brought under cultivation and in reasonably easy reach of large consuming centers, is in use, though much of it, possibly 85 per cent., is not yielding full returns. Extension of the farmed area will consequently be made with greater expense for clearing, preparation, drainage, and irrigation, and for profitable operation will involve marketing arrangements of a high degree of perfection and the discriminating selection of crops having a relatively high unit value.

Interest in land for homes and farms increases in the Nation as the population grows. It has become more marked as the area of public land suitable and available for agriculture has diminished. It is intensified by reason of the suggestion and desire that returned soldiers and others who may wish to secure farms shall have an opportunity to do so under suitable conditions. It finds expression, too, in discussion of the number of tenant farmers and in its meaning and significance.

To a certain extent, we are still pioneering the continent, agriculturally and otherwise, and are still exporters of food, feedstuffs, and materials for clothing. 
With wise foresight and increased employment of scientific practice, under the stimulation of intelligent agencies, we can take care of and provide for a very much larger population under even more favorable circumstances and in greater prosperity. This is the task to which the Nation has set itself and indicates the responsibility resting upon each individual, and especially upon the farming population and state and federal agencies responsible for leadership. We have, up to the present, succeded in this enterprise. In the years from 1900 to 1915 the Nation gained a population of approximately 22,000,000, and they have been fed and clothed, in large measure, from domestic sources. It is estimated that in the years from 1915 to 1918 the population increased by $3,200,000$, of which a very small part was from immigration. We shall, perhaps, gain as many more in the next fifteen or twenty years, even if the rate of immigration should not be maintained, for the natural growth in recent years, averaging about three fourths of a million a year, shows an upward tendency.

It would be desirable to facilitate land settlement in more orderly fashion. This can be effected in a measure by systematic effort on the part of the Federal Government, the States, and the several communities through appropriate agencies to furnish more reliable information, intelligent guidance, and well-considered settlement plans. The Nation has suffered not a little from irresponsible and haphazard private direction of settlement. In many sections, especially in the newer and more rapidly developing ones, the situation has been complicated by the activities of promoters whose main 
concern was to dispose of their properties. They, too, frequently succeeded in attracting farmers to localities remote from markets where they either failed to produce crops or met with disaster through lack of marketing arrangements.

It is particularly vital that by every feasible means, the process of acquiring ownership of farms be encouraged and hastened. This process is real in spite of appearances to the contrary. It has been too generally assumed and represented that tenancy has increased at the expense of ownership and that we are witnessing agricultural deterioration in this direction. Tenancy does present aspects which should cause great concern, but its bright sides have not been sufficiently considered. The situation does not warrant a pessimistic conclusion. In the thirty years from 1880 to 1910 the number of farms in the United States increased from $4,009,000$ to $6,362,000$; the number of those owned from $2,984,000$ to $4,007,000$, a gain of $1,023,000$, or 34.3 per cent.; and the number operated by tenants from $1,025,000$ to $2,355,000$, a gain of $1,330,000$, or 129.9 per cent. But in 1910 five eighths of the farms and 68 per cent. of the acreage of all lands in farms were operated by owners and 65 per cent. of the improved lands. The number of farms increased faster than the agricultural population. The only class not operating farms who could take them up were the younger men, and it is largely from them that the class of tenants has been recruited.

In a recent study of the cases of 9,000 farmers, mainly in the Middle Western States lying in the Mississippi Valley, it was found that more than 90 per cent. 
were brought up on farms; that $311 / 2$ per cent. remained on thcir father's farms until they became owners and 27 per cent. until they became tenants, then owners; that $131 / 2$ per cent. passed from wage-earners to ownership, skipping the tenant stage; and that 18 per cent. were first farm boys, then wage-earners, later tenants, and finally owners. It is stated on the basis of census statistics, that 76 per cent. of the farmers under twenty-five years of age are tenants, while the percentage falls with age, so that among those fiftyfive years old and above only 20 per cent. are tenants. In the older section of the country (except in the South which has a large negro population), that is, in the New England and Middle Atlantic States, the tenant farmers formed a smaller proportion in 1910 than in 1900. This is also the case with the Rocky Mountains and Pacific Divisions, where there has been a relative abundance of lands. The conditions on the whole, therefore, are not in the direction of deterioration but of improvement. "The process has been one of emergence of wage laborers and sons of farmers first to tenancy and then to ownership.

The last six years have been especially fruitful of legislation and of its practical application for the betterment of agriculture. Special provision was made for the solution of problems in behalf of agriculture, embracing marketing and rural finance. The Bureau of Markets, unique of its kind and excelling in range of activities and financial support any other similar existing organization, was created and is rendering effective service in a great number of directions. Standards for stable agricultural products were provided for and 
have been announced and applied under the terms of the cotton-futures and grain-standards acts. Authority to license bonded warehouses which handle certain agricultural products was given to the Department, and the indications are that with normal conditions the operation of the act will result in the better storing of farm products, the stabilization of marketing processes, and the issuance of more easily negotiable warehouse receipts. The agricultural extension machinery, the greatest educational system ever devised for men and women engaged in their daily tasks, had very large and striking development. The Federal aid road act resulted in legislation for more satisfactory central highway agencies in many states and the systematic planning of road systems throughout the Union. To-day each state has a highway authority, with the requisite power and with adequate funds to meet the requirements of the Federal measure.

The Federal reserve act, which has benefited every citizen through its influence on banking throughout the Union, included provisions especially designed to assist the farming population. It authorized national banks to lend money on farm mortgages and recognized the peculiar needs of the farmer by giving his paper a maturity period of six months. This was followed by the Federal farm loan act which created a banking system reaching intimately into the rural districts and operating on terms suited to the farm-owner's needs. This system began operations under the troubled conditions of the world war, and its activities were impeded by the vast changes incident to the entry of this country into the conflict. But, in spite of these difficulties, it 
has made remarkable headway, and there is little doubt that its development will be rapid and will more than fill the expectations of the people.

The operation of the farm loan system, through arrangements by which those who have sold land take a second mortgage subordinate to the first mortgage of the farm loan banks, carrying a relatively low rate of interest, will have a beneficial influence. If further developments can be made through the application of the principle of coöperation, especially in the formation of personal credit unions, the conditions will be more favorable. In the meantime special attention and study should be given to the terms of tenancy, including the lease contract, with a view to increase the interest both of the landlord and of the tenant in soil improvement and to make sure that there is an equitable division of the income.

It still seems clear that there should be provided a system of personal credit unions, especially for the benefit of individuals whose financial circumstances and scale of operations make it difficult for them to secure accommodations through the ordinary channels. Organized commercial banks make short-term loans of a great aggregate volume to the farmers of the Nation possessing the requisite individual credit, but there are many farmers who because of their circumstances, are prevented from securing the accommodations they need.

An investigation by the Department to determine the extent to which farmers in the Southern States were dependent upon credit obtained from merchants revealed the fact that 60 per cent. of them were operating under the "advancing system." The men I have especially 
in mind are those whose operations are on a small scale and who are not in most cases intimately in touch with banking machinery, who know too little about financial operations, and whose cases usually do not receive the affirmative attention and sympathy of the banker. Such farmers would be much benefited by membership in cooperative credit associations or unions.

Of course there are still other farmers whose standards of living and productive ability are low, who usually cultivate the less satisfactory lands, who might not be received at the present into such associations. This class peculiarly excites interest and sympathy, but it is difficult to see how any concrete financial arrangement will reach it immediately. The great things that can be done for this element of our farming population are the things that agricultural agencies are doing for all classes but must do for it with zeal. The approach to the solution of its difficulty is an educational one, involving better farming, marketing, schools, health arrangements, and more sympathetic aid from the merchant and the banker. If the business men of the towns and cities primarily dependent on the rural districts realize that the salvation of their communities depends on the development of the back country and will give their organizing ability to the solution of the problem in support of the plans of the organized agricultural agencies responsible for leadership, much headway will be made.

The foundation for effective work in this direction is the successful promotion of coöperative associations among farmers, not only for better finance but also for better production, distribution, and better living con- 
ditions. These activities are of primary importance. At the same time, it is recognized that such coöperation cannot be forced upon a community, but must be a growth resulting from the volunteer, intelligent efforts of the farmers themselves.

The Department has steadily labored especially to promote this movement by conducting educational and demonstrational work. Field agents in marketing have been placed in some of the states to give it special attention, and the county agents and other extension workers have rendered, and will continue to render, valuable assistance. The operations of the Farm Loan Board, especially in promoting the creation of its farm loan association, should be influential and highly beneficial.

The Department, with its existing forces and available funds, will continue to foster the coöperative movement and to keep in close touch with the Federal Farm Loan Board.

Difficult as are the problems of production, they are relatively simple compared with those of distribution. Only within recent years have agencies been created by the Federal and some of the state governments to assist in the marketing of farm products. Six years ago the present Bureau of Markets began its work as a small office with a very limited appropriation, and it has been carefully investigating the important marketing problems, expanding its field services, administering regulatory laws intended to correct abuses, and encouraging coöperative enterprises. It has been dealing with the many important questions involved in the standardization of production, the proper handling and packing of 
farm products, the use of standard containers, proper storage on farms, in transit, and at marketing centers, and the stimulation of the formation of farmers' cooperative selling and purchasing agencies. It has assisted in the preparation and installation of accounting systems for, and has rendered active service to farmers in promoting coöperative enterprises. It has furnished suggestions for state legislation governing coöperative organization, and in conjunction with the state authorities, it employs trained men to advise 0 =tension workers, including the county agents, with reference to the marketing of their products and market organization problems. It conducts an inspection service on fruits and vegetables at 163 important central markets.

It has in operation a nation-wide market news service which gives to producers information regarding conditions in the markets they can and should reach and to consumers information relative to current supplies and prices. In coöperation with a number of states, it issues exchange marketing lists periodically, which make known to county agents, breeders, and feeders where surpluses of live stock, feed, and seeds are to be found. It enforces four important regulatory measures, namely, the grain standards, the cotton futures, the standard basket, and the United States warehouse acts, which were enacted to correct abuses and to enable the farmer to sell his products more nearly for what they actually are worth.

While the Bureau is already dealing with most of the larger problems involved in the distribution of agricultural commodities, its activities could be profitably cxpanded in many directions. It would be desirable, for 
instance, for it to have in each state one or more trained men working in coöperation with the state authorities to stimulate coöperative enterprises and to aid farmers in solving their marketing difficulties. The Market News Service could be extended with great advantage if the requisite funds were provided; and further work should be done in the matter of establishing standards. Three bills already have been introduced in Congress looking toward the establishment of standards for fruits and vegetables, feeds and cotton; and bills are now before the Congress for the supervision of the packing plants and stockyards, as well as for the regulation of cold storage. All these things would aid, directly or indirectly, in promoting the more systematic and orderly marketing of farm products.

It is unnecessary to emphasize the vital importance of good roads both to urban and rural communities. In rural communities they are a prerequisite for effective agricultural production and marketing, for good schools, and for an attractive country life. During the war it was necessary to curtail road-construction operations, because of the difficulty of securing transportation, materials, and the requisite services. After the signing of the armistice, the work was actively resumed and vigorously prosecuted notwithstanding the fact that conditions were abnormal in some respects, especially in reference to the prices of materials and supplies.

The Congress at its last session, accepting the recommendations of the Department of Agriculture, not only made available from the Federal Treasury large sums, aggregating $\$ 209,000,000$, in addition to the original 
appropriation of $\$ 85,000,000$ in the Federal Aid Road Act, for road construction in coöperation with the states, but also made some important amendments to the Road Act. These amendments have had the effect of greatly lessening the difficulties of selecting and constructing needed roads.

The Federal Road Act, as amended, places only three limitations on the type of road to be constructed, as follows: The road must be substantial in character; it must be a "public" road a major portion of which is now used, or can be used, or forms a connecting link not to exceed ten miles in length of any road or roads now or hereafter used for the transportation of the United States mails; and the amount contributed from the Federal Treasury for its construction must not exceed 50 per cent. of the cost, or, in any event, $\$ 20,000$ a mile. Under the terms of the amended act, therefore, there are few important roads which will be debarred from receiving Federal aid.

It will thus be seen that a broad and comprehensive road-building program has been inaugurated. This program is being vigorously pushed, and the indications are that a larger volume of highway construction will have been accomplished this season than in any previous year in the history of the Nation. Furthermore, the work is being done in such a way as to utilize to the best advantage the road-building experience and facilities of the whole country.

The purpose of the Federal Aid Road Law is to encourage the construction of roads of a substantial nature by the states and to provide adequate safeguards for securing systematic and economical action. 
Long experience has shown that the best results will be secured if the work is performed under the supervision of the state highway departments, the method of the control depending upon local conditions. The greater the administrative and technical ability of these departments, the greater will be their usefulness to the taxpayers of the state. Under the Federal Law, the state highway departments have been strengthened and developed in a way that could not be equalled under any other type of national road legislation that has been suggested. The progress that has been made in this direction is very gratifying and helpful.

By devoting all its energy to helping each state inaugurate the work as quickly and as extensively as possible, the Department of Agriculture multiplies its resources forty-eight times, and is a coöperator instead of a competitor in placing men and materials on the highways where they are most needed. The Department is maintaining the closest possible touch with the state highway departments, and, at its request, the American Association of State Highway Officials has designated some of its members to serve on an advisory committee to coöperate with the Department in the administration and execution of the provisions of the Federal Aid Act.

At present, in order to secure for the public the benefits of the provisions of the Federal Food and Drugs Act with reference to animal feeds, it is necessary to rely on the appropriate statutes of the different states. These are not uniform and there are a few states which have no laws that can be invoked. It is believed that it would be wise to have a comprehensive 
Federal feed law placed upon the statute books, under which the Government could proceed in a uniform manner and secure to consumers adequate protection against misbranded, adulterated, and worthless feeds entering into interstate commerce. It is obvious, of course, that if such laws could be enacted they should result in the protection not only of the consumer, but also of the honest manufacturer and distributor.

It is difficult to say what the world food situation will be at the end of the next harvest season and what will be the course of prices for farm products. For the next twelve months the world will subsist, in large measure, on food products already produced. The consensus of opinion, so far as the production program of this nation is concerned, is that it would be wise for the farmers to return to the normal as promptly as possible and to resume operations best suited to their particular conditions, realizing that the present calls for the fullest measure of economical production and for the practice of thrift. In their tasks for the future, as in the past, they will have at their disposal and for their aid the services of the Federal and state departments of agriculture and of the great state land grant collegesagencies which in the aggregate, as regards numbers of personnel, activities, and financial support, exceed those of any three nations in the world combined. 


\section{XVII}

\section{PRINCIPLES OF EUROPEAN LAND-CREDITS *}

\section{Dick T. Morgan}

There is a crisis in land-credit legislation! The turning point has been reached. The critical moment has arrived. An emergency exists. An exigency confronts the nation. A false step now may be irretraceable, a blunder at this time may be incurable, a mistake made at this juncture may be irretrievable, and an error committed in the pending crisis may be forever irreparable.

In this crisis in land-credit legislation great interests are at stake. The prosperity of 6,500,000 farmers is involved. Forty-five million men, women, and children on our farms, and untold millions to follow them, are directly, intensely, and vitally interested. The fate of agriculture-its growth, development, and expansionthe annual wealth produced thereby, and its ability to produce an adequate supply of food products for our rapidly increasing population, depend in a large measure upon the outcome of the pending crisis.

This crisis involves more than the physical and material well-being of our farmers and their families. The sweep of its influence includes their intellectual growth, their social welfare, and their moral and spiritual development. Its impress will tell on their

*From "Land Credits," by permission of the author. 
schools, their churches, their homes, their manhood and womanhood, and upon their lives and their hearts.

The result of this crisis will determine the attitude of our Federal government toward the farmers of the United States. It will show what appreciation this government has for the $12,500,000$ people who toil upon our farms. It will indicate the policy of this government toward these people and their industry. Finally, it will show what respect this government has for the rights of the $45,000,000$ men, women, and children who reside upon our farms.

This crisis will not stop with the farmers. Its effect will not be restricted to agriculture. Its influence will not be confined to rural life. Its sway will not be limited to the country districts. It will involve every industry, business, calling, and profession of life. Its influence will extend to every section of the land, to every state in the Union, and to every home and fireside. Commerce, manufacturing, mining, trade, transportation, merchandising, banking, clerical pursuit, the learned professions-all are interested. The rich and the poor, the millionaire and the pauper, labor and capital, employers and employees, merchants, artisans, day-laborers, and wage-earners-all will be affected by the solution of the existing emergency in land-credit legislation.

This crisis is not a creature of the imagination. It is not an illusion, a delusion, a fable, a dream, or a shadow. It is real and tangible. It may be seen and felt, comprehended and understood. It extends in every direction, touches our national life at every point, and encompasses the whole land. 
Settle this crisis right and the republic will be strengthened, its power and influence will be augmented, its prestige will be enhanced, its fame will be magnified, its principles and ideals will be emphasized and accentuated, its resources and wealth will be multiplied, its security will be increased, its hands will be strengthened, and under its flag will dwell a better citizenship, and a happier, more contented, and prosperous people.

All European land-credit systems which provide for long-term, farm-mortgage loans are alike in some important features. Germany, for instance, has several classes or kinds of land-credit institutions, organized under different laws, but they all have some things in common. So throughout Europe whatever may be the character of the institutions, associations, or corporations, whether they be associations of borrowers, or organizations of lenders, profit-sharing or non-profitsharing, conducted for gain or for the public good, founded by private capital, or endowed by the statethey are alike in some essential principles, features, and characteristics. Among the common features of these institutions may be mentioned the following:

1. They are all authorized by law, regulated by statute, and are subject to some kind of state or governmental supervision.

2. They all make unrecallable, long-time, reducible loans.

3. They all issue long-time bonds or debentures.

4. They all require the principal debt to be paid by annual or semi-annual amortization payments.

5. All make their bonds or debentures absolutely secure. 
1. Authorized by Lare. Upon these fundamental propositions the land-credit systems of Europe are founded. These essential features must, of course, be embodied in the land-credit system of the United States. Obviously there can be no system or plan of land-credit without legal authority. Through state or Federal legislation land-credit institutions must be authorized. Private individuals cannot supply agriculture with credit. In this country, and in all other countries, ordinary commercial banks have failed to supply agriculture with proper credit. Banks doing business on deposits, subject to check, are unsuited to extend credit on land security. Individual money lenders are unequal to the task. The law must authorize the formation of institutions especially designed to provide agricultural credit. As the modern business corporation has served all kinds of industrial and commercial enterprises, so it must serve the farmers in supplying them with credit. The farmers' land-credit corporation must have the sanction of legislation. It must have the prestige of the law behind it. Without this no land-credit institution can gain and hold the confidence of the public. So the first step is to create, through statutory enactment, artificial persons-corporations, associations, or institutions-and send them forth into the business world, clothed with the authority of the law, approved and sanctioned by the Federal government, designed, delegated, directed, and commissioned to perform the definite, specific work of providing agriculture with adequate credit facilities. In addition to being authorized by law, they must be supervised by Federal authority. Some of the land- 
credit institutions are supervised by state or provincial authorities. These institutions have, however, lost by this rather than gained. There has been some discussion as to whether our land-credit institutions should be state or Federal institutions. A few of the states have authorized the organization of farm-credit banking institutions. But nothing worth while can be accomplished in this country except through national legislation, national incorporation, and national supervision. This supervision can hardly be too severe. Anything which impairs confidence in our land-credit institutions will be absolutely fatal to their permanency and success. The Federal government, creating these institutions, must see to it that their business is conducted in a way that will protect both borrowers and investors, and insure both permanency and efficiency. The law itself must throw around them such general rules as will standardize their business methods and keep them within the limits of perfect safety. But beyond this, there must be such official inspection, oversight, and surveillance as will preclude losses through dishonesty, speculation, negligence, or inefficiency.

2. Long-time Loans. In Europe long-time loans run from ten to seventy-five years. Farm loans in the United States generally do not.run for a period to exceed five years. In other words, as the term is used in Europe, American farmers have no long-time loans. This is one great defect in our present farm-loan business. It is unjust to the farmer in many ways. Mr. Oren Taft, Jr., of Chicago, who has had extensive experience in the farm-loan business, in an article in "Trust Companies," in September, 1904, page 71\%, 
referring to the short-time farm loans in the United States, calls attention to the fact that on the average farm loans in this country run for a period of fifteen years, though on an average they are made for less than five years, thus imposing upon borrowers not only great annoyance, but also heavy expense for renewals of loans.

Land-credit systems vary somewhat in the duration of long-term loans. In France the maximum time for which a farm loan may be made is 75 years. In Ireland loans may be made for 681/2 years, in Switzerland for 57 years, in Germany $561 / 2$ years, in Sweden $561 / 2$ years, in Russia 551/2 years, in Australia 541/2 years, in Japan 50 years, in Italy 50 years, in Austria 42 years, in New Zealand 361/2 years, in Chile 33 years, and in Finland 30 years.*

There are many advantages to the borrower in having a long time mortgage loan system. Under it, on reasonable notice, he is entitled to pay the full amount of his loan at any time. For this privilege he pays no commission or bonus. He may pay all or any part of his debt at reasonable intervals. He is thus in a position to take advantage of any reduction in interest rates. If he makes a loan for $\$ 1,000$ for fifty years, at 5 per cent. interest, and thereafter at any time the prevailing rate of interest lowers, he can reborrow at the lower rate and pay off his original loan. On the other hand, if he borrows at 4 per cent., for fifty years, and the interest rate rises, the loan institution cannot demand a higher rate. The long-time loan protects the farmer against misfortune. In farming,

* Herrick, page 211. 
as in other lines of business, misfortune and hard times may come. Every country has unfavorable seasons. They may come in succession. The farmer contends with drouths, storms, floods, insects, and diseases in plant and animals. Without his fault a year's labor may be lost. There may come a series of years in which he fails to make a living. Financially he falls behind. Unexpectedly he finds himself in straitened financial circumstances. Under these circumstances he cannot pay a short-time mortgage, when it is due. Renewals are often difficult to secure. Sometimes they can be secured only on the payment of a large commission and higher rates of interest. With a long-time farm mortgage the farmer has ample time to recoup his losses. In long-time loans there is a lifetime in which to pay the principal. Annual payments are small. Borrowers have time to tide over failures, misfortunes, unforeseen and unexpected reverses and losses. The peace of mind which these privileges afford is worth much to the borrower and his family. The man carrying a long-term mortgage loan is a better citizen than the one who lives constantly in fear of foreclosure, ejectment, and loss of home. This is an asset to the community and the State. Under the short-term mortgage loan practice in vogue in this country the borrowers are pressed to the limit to meet the payment of the principal of their debts. They and their families are kept under constant strain. Every effort is put forth. Every member of the family must sacrifice. The children are denied educational advantages. They are cut off from opportunities of greater usefulness. Even if the borrower succeeds in meeting his obliga- 
tion when due, the cost has been too great. A long-term mortgage loan system will, therefore, become a factor in social uplift, in conserving and improving the physical strength of our farming population, in extending to them better facilities for intellectual development, and in enlarging, broadening, and multiplying their opportunities in life. The long-time farm mortgage loan enables the borrower to do better farming. He will have additional funds to enlarge his farming operations, to provide better machinery, implements, and tools, to acquire more live stock, to erect more suitable farm buildings, to plant orchards, grow timber, reclaim unproductive lands, and to acquire many other things which will make the farm more productive, more profitable, and more attractive. The long-term farm loan will enable the average farmer greatly to reduce the amount of his personal short-time indebtedness, which he now owes his local banker, or merchant from whom he buys supplies on time. These short-time loans are on personal or chattel security; ordinarily they run at a high rate of interest. With longer time in which to meet the farm-mortgage indebtedness, the farmer will have a greater surplus of funds. More generally, he will be a cash customer for the merchant. To a larger extent he becomes a depositor in the local bank, which will reap a profit in loaning his funds to others. Here, it might be added, it is that the establishment of a long-term system of farm land mortgage credit will benefit, not injure, commercial banks. The vast majority of these banks are comparatively small institutions, located in farm communities. They are almost entirely dependent upon 
agriculture. Any change in our farm-credit system which increases the production of the soil, enlarges. farming operations, or augments the prosperity of the farmers, will add to the value of the capital stock of every bank located in a farming community, and will increase its dividends, surplus, and profits. The commercial banks should be enthusiastic supporters of the movement to give the farmers of the United States the very best system of land-credit that can be devised. Finally, the long-term farm mortgage is absolutely essential to meet the wants of tenants and other persons of limited means who wish to acquire farm homesteads. It is true that we do not have in this country liberated serfs or any class of farmers on a level with the peasants of some of the European countries. However, about one third of our farmers are tenants. The census of 1910 shows that we had in this country 6,361,502 farmers. Two million, three hundred fiftyfour thousand, six hundred and seventy-six of these were tenants. It is not necessary to enter upon an argument to show the evils of farm tenancy. All thoughtful persons recognize the importance of encouraging home-owning in both the country and city. One of the wisest things this country ever did was to dedicate the public domain to provide homes for the homeless. There was a time when some of our prominent statesmen contended that primarily the public domain should be used as a source of revenue to the national government. For some years it was so used. The free homestead law did not pass without a struggle. It was passed by both Houses of Congress once, and vetoed by one of our Presidents. The measure finally 
became a law and received the approval of Abraham Lincoln. Vast millions of dollars were thus diverted from the national treasury. Indirectly these funds flowed back into the treasury in far greater abundance; we became a greater and stronger nation; and our citizenship was strengthened in loyalty, fidelity, and devotion to the principles of our free government. With the cream of our public domain already gone, this government should enter vigorously upon a plan to promote home-owning among our citizenship. Our task is not so great or so difficult as that which confronted many of the European countries. We do not have to deal with problems which confronted Russia when she liberated her $22,000,000$ serfs. We do not need to use a thousand millions of dollars in funds of this government which England will probably finally expend in acquiring homes for the peasants of Ireland. It will not be necessary for us to authorize the expropriation of lands in private ownership to secure homes for our tenants and for others who wish to acquire farm homesteads. If we establish a proper system of long-term mortgage loans, modeled after the best systems of Europe, with reasonable aid in the funds or credit of the national government, the tenancy problem in the United States will solve itself. And as the years shall go by we shall see through the reports of our decennial census that proportionately our farm tenants are growing less, that we are making substantial progress in reclaiming waste and unproductive lands, and that millions of our people through long-term mortgage credit have become independent, self-respecting, happy, patriotic farm-home owners. 
3. The Bonds and Debentures. One of the most important discoveries in the world was the invention of the farm-mortgage bond or debenture as an instrument to promote land-credit. There never has been a successful system of land-credit established in any country that does not utilize the mortgage bond or debenture as an instrument to mobilize and liquefy land values. Through the mortgage bond or debenture the farm mortgage has been made easily negotiable, and put in such a form that the holder may realize thereon immediately. The mortgage bond and the debenture in effect are the same. The term "mortgage bond" is used to indicate bonds or securities secured by certain specified and designated mortgages. The "debenture" is an obligation of a bank or other institution, secured not by a number of specific mortgages, but by the general assets of the institution issuing the debenture. For instance, the Crédit Foncier of France estimates that it will need $\$ 50,000,000$ additional money on which to make farm mortgage loans. Under the law it may issue and sell $\$ 50,000,000$ in debentures even before it makes the loans, while a bank, issuing mortgage bonds, would first make the loans, and place the mortgages in trust as a special security for the bonds issued thereon. Thus the designated mortgages become the chief security for a certain issue of bonds, and the institution must keep deposited in trust farm mortgages to secure its bonds in an amount equal to the total of bonds issued. The bonds must not exceed the amount of mortgages deposited in trust to secure their payment. If a mortgage is paid, another mortgage of equal face value must be deposited in trust in lieu of it. In principle and in 
practice the mortgage bond and debenture serve the same purpose. The Landschaften of Germany issue debentures. Their debentures in amount always correspond with the amount of the mortgages held by the Landschaft. This must be true because the Landschaft does not pay the borrower the cash, but simply delivers to him bonds in an amount equal to his mortgage. The borrower takes the bonds and disposes of them himself. He may sell them to one or more individuals, or to a bank, or through the bank of the Landschaft, which has been in many cases organized especially to aid borrowers to dispose of their bonds. The jointstock mortgage banks pay their loans in cash. They issue mortgage bonds, which are secured by designated farm mortgages of an equal amount. These mortgages are invariably deposited in trust to secure the payment of the bonds. The specific mortgages deposited in trust are not the sole security for the payment of mortgage bonds. The mortgage banks are required to set aside certain reserve or guaranty funds to provide against losses from the non-payment of the principal or interest on mortgages held in trust. Finally, of course, the capital of the mortgage bank, its surplus, and all of its assets would be used, if necessary, to redeem any outstanding mortgage bond. Generally, of course, the bondholders have a special and prior lien over other creditors upon the mortgages deposited in trust to secure bonds issued thereon. The bond and debenture are the farm mortgage in another form. The farm-loan institutions collect farm mortgages, and then, by the authority of law and under governmental supervision, change their form into 
a security suitable to the needs and wants of investors, large or small, and in form and character corresponding to securities of all other kinds, familiar to the financial world. The farm mortgages lie in safe seclusion. The bond and debenture, their representatives, are out "in company," commanding recognition even above the best industrial securities, and selling practically upon a par with bonds issued by the greatest and strongest government of Europe.

The change of farm mortgages into bonds or debentures is like the process of mining, modifying, and purif ying minerals. Iron, copper, lead, zinc, silver, and gold, as taken from the mines, are not suitable for commerce, but through various processes these minerals are refined and made in form to meet the needs of commerce, industry, the arts, and the innumerable wants of mankind. So through mortgage bonds or debentures farm mortgages are changed in form, modified and refined, and made to conform to the needs of investors, banks, and credit institutions, to serve agriculture, and to contribute materially to the welfare of our farmers and all other classes of our citizens.

The bonds and debentures of the European landcredit institutions are payable at no fixed time. The holder and owner of a mortgage bond or debenture can never demand its payment. The institution which issues the bond or debenture may recall and redeem the bonds at its pleasure. The bonds and debentures are redeemed by issuing institutions in the same ratio that mortgages are paid. This is obligatory upon landcredit institutions. The outstanding bonds must never exceed the amount of unpaid, existing mortgages. The 
bonds or debentures to be retired are determined by some system of drawing. Bonds and debentures must be redeemed at par. 'The fact that there is no fixed time for the payment of the bonds and debentures at first would appear to be a serious objection thereto. But this, however, is not true. These bonds and debentures are highly liquid securities. They are generally payable to bearer. They are transferable by mere delivery. They are easily negotiated and assigned. They may be used as collateral security for loans. They are regarded as gilt-edged security. Perhaps more than any other security they are like money itself. Indeed, the effort to make land the basis for money, the circulating medium of the country, appears to be responsible for the invention of the land debenture. The owner of a mortgage bond or debenture is not concerned as to the time it will be paid by the issuing institution. He may at any time realize cash therefor. Whenever he wishes to change the form of his investment, he can do so without any material loss, because there are always buyers for these securities.

4. Amortization Payments. All the land-credit institutions of Europe, for long-time loans, require the principal to be paid by annual or semi-annual payments. Usually the payments are made semi-annually. These are called amortization payments. Amortization means "the extinction or reduction of a debt through a sinking fund." To amortize a debt signifies to destroy, kill, or extinguish it by means of a sinking fund. The small annual payments made by borrowers are placed in a sinking fund. A sinking fund is a fund that is "instituted and invested in such a manner that 
its gradual accumulations will enable it to meet and wipe out a debt at its maturity." The land-credit institutions issue bonds or debentures in amounts corresponding to the aggregate value of their mortgages. These bonds or debentures on their face are the debt of the institution issuing them. Primarily the bonds and debentures are the debt of the borrowers, who have executed and delivered their mortgages to land-credit corporations. Interest must be paid on these bonds and debentures. Ultimately the principal of the bonds must be paid. The mortgagors must pay both the interest and principal and in addition must contribute an additional fund to meet the cost of operation, or administration charges, including whatever profits are made. The land-credit institution, whatever be its name or character, acts merely as the agent of the borrowers. It is merely an intermediary between borrowers and investors. Even if it be a non-profit-sharing institution, it contributes nothing to the payment of principal, interest, or administration charges. But to enable the borrowers to meet the obligations they owe the credit institutions, and to make it possible for these institutions to extinguish their bonded indebtedness, which they have incurred to secure funds with which to make loans to farmers, a sinking fund is created, to which every borrower contributes a certain definite and fixed sum, payable annually or semi-annually. These sinking-fund payments are either invested for the use and benefit of borrowers or are used in redeeming outstanding bonds or debentures. The use of amortization payments to extinguish long-time farm loans is a feature of the land-credit systems of Europe of the 
highest importance. The long-time loan, the mortgagebond or debenture, and the amortization payments are the triple combination which is in the main responsible for the success of all existing systems of land-credit. The land-credit systems of Europe require that borrowers shall pay at least one half of one per cent. per annum upon the principal of their debt. The payment of this amount annually will liquidate the debt in fifty-six and one half years. The advantages of paying a debt by small annual payments are many. In the first place it stimulates thrift. It encourages systematic saving. It is the only method by which the average person of small means can acquire and pay for a farm-home. Only institutions authorized to make long-time loans and issue and sell long-time bonds or debentures can make loans payable in small annual payments. The individual money lender would not care to accept the payment of the principal of a loan in driblets. Land-mortgage institutions may accept small payments, because the funds which they use in making loans are borrowed from investors through the sale of long-time bonds or debentures. Small annual or semi-annual payments, contributed by numerous borrowers, pouring into a common treasury, with regularity, precision, and certainty, create a fund ample to liquidate at maturity the bond or debenture indebtedness of the largest land-credit institution.

5. Absolute Security of Bonds and Debentures. The success of any land-credit system depends upon the absolute security of the bonds and debentures issued by the corporations empowered to operate the business. The bonds and debentures run for long years. Gen- 
erally, under European land-credit systems, there is no fixed time for their maturity. In duration they live beyond the life time of a generation. The active managers of an institution at the time a series of bonds is issued may not live to see them all paid. The sale of bonds and debentures is the source through which the funds come to provide agriculture with its credit. The streams of credit would soon cease to flow into the treasury of the land-credit institutions, if there were the least doubt about the absolute safety of their securities. Other defects in a land-credit system may be overlooked. This or that may distinguish one system from another. One system may be successful in one country; a different one may prosper in another country. One may be better or worse than the other. None of them can be permanent or successful unless the investing public has perfect confidence in the securities offered to investors. In founding land-credit institutions, European countries have exercised the highest diligence to insure the safety of mortgage bonds and debentures. Every reasonable precaution and safeguard has been utilized. In the old Landschaften the principle of unlimited liability was adopted. In later years, some of the Landschaften have abandoned this idea. Where this has been done, other safeguards have been substituted. The amount of a loan upon a farm is limited to a certain percentage of the appraised value of the farm. Appraisements are conservative. Definite and fixed rules are applied in ascertaining the actual value of the land mortgaged. The loan institutions carefully inspect property during the lifetime of the loan. Any serious deterioration in the value of prop- 
erty makes the mortgage subject to foreclosure. Provision is made to remove all question of title to the mortgaged property. Many of the loan institutions have special privileges in the steps necessary to enforce payment. The officers of the Landschaften of Germany are clothed with executive, administrative, and judicial powers, such as are exercised by courts and public officials. The law limits and restricts the business of all land-credit institutions. Officers are required to make frequent reports. Governmental inspection is authorized. In the internal administration of these institutions, one officer acts as a check upon another. Some provision is made in all institutions for the accumulation of reserves and guaranty funds, designed especially to meet losses through non-payment of interest and principal of any loan. All of which are essential. A bond or debenture of doubtful security cannot be sold. This is not all. The safety of the bond or debenture affects the rate of interest on the bond. The safer the security, the lower the interest. To secure high interest, some investors may purchase a bond or debenture of questionable security. But a security with a low rate of interest cannot be sold in large quantities unless it is regarded as absolutely safe. In establishing land-credit institutions for the United States, "safety first" would be an excellent motto. In the inauguration of a new land-credit system in the United States, bonds and debentures must be made secure. The farmer possesses the land which in itself is absolute security for the money which will be loaned to him. That security must not be vitiated, impaired, or deteriorated by the corporation-whatever may be its 
title or name- brought into existence by the national government to collect and market the security the farmer presents. The farmer-not the land bank-is most deeply and vitally interested in the safety of the mortgage bonds issued. It has been demonstrated by European experience that the principle of unlimited liability is not essential to the safety of land securities. For many reasons, this feature would be objectionable to American farmers. Being unnecessary, it should not be adopted in this country. In many of the European countries, the provincial, State or imperial governments guarantee the payment of bonds or debentures issued by the public land-credit institutions. Such guaranty has not been extended to private, joint-stock, profitsharing, land-mortgage institutions. Without discussing here the question of government aid, the Federal government, in assuming the responsibility of creating national land-credit institutions, must, above all things else, see to it that the bonds or debentures issued by these institutions shall be securities about the safety of which there can be and will be no question. 


\section{XVIII}

\section{REDUCING THE COST OF LIVING-}

\section{A COMMON PROBLEM *}

\section{Edwin T. Meredith}

There is an idea, fairly widespread and deep rooted, that reducing the cost of living is essentially an agricultural problem. Reducing the cost of living, however, is a mutual problem and if satisfactory results are secured business men must also give their attention to the problem. Getting food delivered at the kitchen door at the right price does not depend solely on how much of it the farmer produces or what price the farmer gets for it. It depends much on the expedition and economy with which it is handled between the farmer's wagon and the pantry. It is a problem common to the whole people, and it cannot be solved unless business and labor, as well as agriculture, put their best intelligence into the solution.

The consumer, of course, pays the production cost of farm products-except when the farmer sells his products for less than it costs to produce them. Production costs are high, and the farmer must get satisfactory prices, or he will have to go out of business. If he goes out of business, both he and the city man will suffer.

* From The Independent, by permission of the author and the publishers, the Independent Corporation. 


\section{Whom the Consumer Supports}

When the farmer has been paid for his product, the bill that the consumer must pay is by no means made out. The consumer pays the freight from the farm to the city market. He pays for all back hauling and round-about hauling that result in so much delay and so much loss of perishable products. He pays for terminal facilities-and, if those facilities are not what they should be, he pays a penalty because of inefficiency. He pays the profits of the commission man, of the wholesale merchant, of the retail grocer, as well as the wages and salaries of the boy who drives the delivery wagon and of everybody who has anything to do with the product from the time it leaves the farm until it reaches the kitchen. Every inefficient man in that chain of distribution, every man who draws a salary or wages for work not needed, every man who does not render honest service, is adding a burden to what the consumer must pay for his food.

When we have taken the lost motion out of distribution and properly emphasized production in the factory and on the farm, we will have gone a far way toward reducing the price that the ultimate consumer pays for his necessities. The farmer and the agencies that operate for and with the farmer, of course, are powerless to do that alone. It can only be done with the help of business men and laboring men everywhere.

\section{Arithmetic of System Needs Revision}

Distribution, of course, is just as essential as production, but, if out of every ten men, we have six engaged in distribution and only four in production, 


\section{REDUCING THE COST OF LIVING 231}

there can be consumed by each of the ten men only four tenths of what.one man can produce. If six of the ten are engaged in production and only four in distribution, each man can have for his own use six tenths instead of four tenths of what one man can produce. The principle applies to the $110,000,000$ people in the United States in exactly the same way that it would apply to ten men marooned on an island. We cannot consume more than we produce, and the quantity produced by the whole tends to decrease with the increase in the number of men unnecessarily engaged in the distribution of the products.

I am not prepared to say that any given number of men should give up merchandizing or the place they may now occupy in distribution and become factory laborers or miners or farmers, but I am prepared to say that, in justice to himself and to his country, every person ought to see to it that there are no drones in his own hive to add to the cost of distributing what the farmer and factory produce, and that every so-called laborer should see that he contributes just as largely as possible to the sum total of production, no matter what article he is making or what duty he may be engaged upon.

The farmer, of course, must produce-and of course he will produce. He gets paid only for what he produces. But there is one thing which will take him out of production and that is to be obliged to sell the product of his year's labor and investment for a price which does not enable him and his family to live as well as his friends in the city who devote their money and energies in other directions. 
"Take UP The Slack," Says the Farmer

The farmers ask, naturally enough, that the high cost of living be approached by all the people as a common problem. They ask that those engaged in distribution "take up the slack," eliminate the lost motion, and refrain from putting so great a burden on production. They ask that the banks, the railroads, wholesale houses, retail establishments and factories-all of which they recognize as vital necessities-be put on the highest plane of efficiency. They look to the factory executive to speed up his operations so that two days' labor instead of three, if possible, will go into a given article which he finds necessary to his comfort or the conduct of his farming operations. Without taking anything from the manufacturer's profit, the farmer's margin is increased because of the fact that his equipment and supplies are thereby reduced in cost, his production is stimulated, and he is encouraged to stay on the farm. The farmer asks these things of business.

The farmer asks also that the laborers in the mine, the factory, and the mill make an effort comparable to his to see that there is just as little labor expense as possible in each article turned out by their hands.

If labor in every line produces all it can produce, if manufacturers, jobbers, and dealers recognize the harm that must ultimately come from profiteering upon the farmer and content themselves with a reasonable profit, an important contribution will have been made to the solution of the problem of reducing the cost of living, to the good of all concerned. On the other hand, if these things are not done, if farming be not as remunerative, pleasant, and attractive as other lines of 
endeavor, conditions will not improve. More and more will the young men leave the farms. More and more will the older men become discouraged. Less and less will there be of farm produce to divide among the whole people for their sustenance and higher and higher will go the price of that which is produced.

\section{Problem for Business Men}

I hope I have made it clear that, in my opinion, the business men of America must recognize the problems of the farmer as their problems also. They must have a real understanding of the farmer's place in our national economy and they must help to provide and maintain facilities which will aid him in his business. The Federal Farm Loan Bank, for instance, is of great advantage to the farmers of America, making money available to them on favorable terms, without commissions, without renewal charges, giving them long time that they may plan ahead where necessary, and financing them to carry on the fundamental activity of the country ; and yet an assault is being made upon this system. The success of the opponents of the Federai Farm Loan Banks would be a blow to agriculture in America and would ultimately result in harm to all. The business men must interest themselves in retaining for the farmer this aid and help in securing others.

On the production side the farmer has aiding him all the accumulated knowledge of the United States Department of Agriculture, the agricultural colleges of the several states, and the experiment stations. The extension machinery of these institutions, functioning through the county agricultural agents and the home 
demonstration agents in a great majority of the agricultural counties of the country, makes the information immediately available and directly applicable to the individual farmer. The county agents and home demonstration agents, while not neglecting production and utilization, are giving more and more attention to the economic end of the farm business, and more attention to buying and selling in coöperation with the Bureau of Markets and the Office of Farm Management in the Department of Agriculture.

\section{Seling the Sfrcond Blade}

It is desirable to make two blades of grass grow where but one grew before, but to encourage this you must have a market where you can sell the second blade at a profit. The farmers of the United States have been able to increase the number of blades and they are beginning to do something on their own account toward getting the extra blades to a profitable market. The farmer would prefer to devote his entire time to production. He has learned, however, that he is not made prosperous simply by what he produces but by what he can dispose of at a fair price, and he is giving more thought to the distribution end of his business than ever before, notwithstanding, as I say, that he would no doubt prefer to devote his whole time and thought to production.

I speak of these things by way of conveying to the business man this assurance: The farmer is not without the inclination or the necessary aids to do his part in reducing the cost of living. He is anxious to do his share and more, and he seeks the coöperation, the sup- 


\section{REDUCING THE COST OF LIVING 235}

port, and good-will of the business world. All those who work together in strengthening agriculture and making it attractive, and this necessitates making it profitable, will aid in strengthening and making permanent the very foundation of our whole economic structure and will render a real service to the Nation as a whole. 


\section{XIX}

\section{AGRICULTURAL READJUSTMENT AND THE HIGH COST OF LIVING*}

\section{Herbert Hoover}

The high cost of living is a temporary economic problem, surrounded by high emotions. The agricultural industry is a permanent economic problem, surrounded by many dangers. We are now entering into our regular four-year period of large promises to sufferers of all kinds. Except to demagogues and to the fellows who farm the farmer, there are no easy formulas; nevertheless, there are constructive forces that can be put in motion-and these are good times to get them talked about.

As bearing upon some suggestion of constructive solution, I wish to establish and analyze certain propositions. Amongst other things they involve a clear understanding of the bearings of different segments of the total price of food between the different links in the chain of production and distribution:

First: That the high cost of living is due largely to inflation and shortage in world production; speculation is an incident of these forces, not the cause.

Second: That the farmer's prices are fixed by the impact of world wholesale prices; that such prices bear only a remote relation to his costs of production.

* Reprinted from the Saturday Evening Post. Copyright, 1920, by the Curtis Publishing Company. By permission of the author and the publishers. 
Third: That any increase or decrease in the cost of placing the farmer's products in the hands of the wholesaler is a deduction from or addition to the farmer's prices; that is, an expansion or contraction of the margin between the farm and wholesale prices makes an increase or decrease in the farmer's return.

Fourth: That increase or decrease in the cost of distributing food from the wholesaler to the door of the ultimate consumer is an addition or deduction predominantly to the consumer's cost; that is, the margin between the wholesaler and consumer in its increases or decreases is largely an addition to or subtraction from the consumer's price.

Fifth: That these two margins in most of our commodities except grain were, before the war, the largest in the world; that they have grown abnormally during the war, except during the year of food control.

Sixth: That analysis of the character of the margin between the farmer and wholesaler will show that decreases in price find immediate reflection on the farmer, while immediate increases in price are absorbed by the trades between, and the farmer gets but a lagging increase.

Seventh: That an analysis of these margins will show that they can be constructively diminished, but that, regrettable as it is, the prosecution of profiteers will not do it.

Eighth: That the problem must be solved, if our agriculture is to be maintained and if the balance between agriculture and general industry is to be preserved so as to prevent our becoming dependent upon 
imports for food, with a train of industrial and national dangers.

That short world production has been one of the causes of rising prices cannot be denied. The warring powers of Europe took sixty million men from production-nearly one third their productive man powerand put it to destruction. They have lived to a great degree by drain of commodities from the United States and thus brought their shortage to our shores. They have not yet altogether recovered from the holidays of victory, the gloom of defeat, the persuasive "isms" that would find production without work, the destruction of their economic unity, transportation, credits, and other fundamentals necessary to maintain production. It will be some time before they do recover. In the meantime, they are perforce reducing their consumptiontheir standard of living-because they have largely exhausted their securities, commodities, or credit to continue the borrowing of our commodities for their own short production, as during the war. The exchange barometer is to-day witness of the end of this procedure of living on borrowed money. In passing, it may be mentioned that exchange is no more a cause of their inability to buy from us than is the barometer the cause of blizzards. The storm is that they have mostly exhausted their credits and they have not recovered production so as to offer commodities to us in exchange for ours.

Our own industrial production, as distinguished from agricultural production, has fallen rapidly since the armistice. Some of the fall is due to war weariness, some to "isms" that have infected us from Europe, 
some to the natural abandonment of high-cost production brought into play during the war, some to strikes, and a host of other wastes. Our consumption has greatly increased after the restraint of war. Decreases had not penetrated our agricultural community up to the 1919 harvest, nor will such decrease arise from these causes, but, as I will set out later, forces are entering that will decrease our agricultural production.

Our production in nearly all important food commodities except sugar is in surplus of our own need. It only becomes a shortage affecting prices under the drain of exports. Therefore it is the world shortage that is affecting our price levels, not, so far, a deficiency for our own needs.

So far as relief from price influence by shortage in production is concerned, it may arise in two ways: First, slowly through gradual recuperation in world production. Second, by compulsory reduction of consumption in Europe through their inability to pay us by commodities, gold, or credits. This latter has been very evident through the drop in exchange and engagements for exports during the past few weeks.

The cost of food to the consumer is divided among the farmers on one hand and storage, manufacture, jobbers, wholesalers, retailers, and transportation on the other. I believe these charges between the farmer and consumer fall into two distinct groups: The charges comprising the rnargin between the farmer and wholesaler, which mainly concern the farmer; and the charges between the wholesaler and consumer, which mainly concern the consumer. To establish this di- 
vision, it is necessary to analyze shortly the datum point by which price is determined.

The diet of the American people from a nutritional -not financial-standpoint comprises the following articles and proportions:

Wheat and rye......................... 29.5

Pork products $\ldots \ldots \ldots \ldots \ldots \ldots \ldots \ldots \ldots \ldots, 15.7$

Dairy products ........................ 15.3

Beef products ........................ 5.3

Corn products ...................... 7.0

Sugar products $\ldots \ldots \ldots \ldots \ldots \ldots \ldots \ldots \ldots \ldots, 13.2$

Vegetabie oils $\ldots \ldots \ldots \ldots \ldots \ldots \ldots \ldots \ldots \ldots, 3.6$

89.6

All others, including potatoes............ 10.4

100.0

The wholesale price of about ninety per cent. of our food in normal times is only remotely determined by the cost of production, but mostly by world conditions.

We export a surplus of most commodities among the ninety per cent., and the prices of exports are determined by competition with other world supplies in the European wholesale markets. Those items in this ninety per cent. that we do not export are influenced by the same forces, because in normal times we import them on any considerable variation in price and the wholesaler naturally buys in the cheapest market. Even milk is to a considerable degree controlled by butter imports in normal times. When we import butter it releases more milk to competition. This cannot be said to such extent of the most of the odd ten per cent., because they are largely perishables that do not stand overseas transport, and consequently rise and fall more nearly directly upon local supply and demand. 


\section{AGRICULTURAL READJUSTMENT 241}

Some economists will at once argue that if prices are unprofitable to the farmer the situation will correct itself by diminished production and, consequently, a general rise in the world level of prices. In the abstract this is true, but as a matter of fact the surplus which our farmers contribute for export is only a small portion of their total production or of the world pool, yet the total of the world pool operating through this minor segment makes the prices for a large part of their commodities. Therefore, the effect in normal times of restriction in production in any one country does not affect price so much as theoretic argument would believe.

The farmer must plant if he would live, and he must plant long in advance of his knowledge of prices or world production. He can make no contracts in advance of his planting, nor can he cease operations on the day prices fall too low. He is driven on, year after year, in hope and necessity, and will continue over long periods with a standard return below rightful living because he has no other course-and always has hopes. He will vary fairly rapidly from one commodity to another-from wheat to other grains, for instance-but he mostly raises his maximum of something. In the long run of decreasing prices he would undoubtedly reach so low a standard as to cease production. Then comes a comparatively short period of higher prices in some commodity; production is again stimulated and followed by long intervals of low standards. As shown by the following table, on the whole, the farmer has not been underpaid during the war, but the currents again are turning against him: 
Prewar ...........100

\section{Department}

of Labor wholesale index of all

First quarter 1918..187

Last quarter 1918. .206

First quarter 1919..200

Last quarter 1919.230

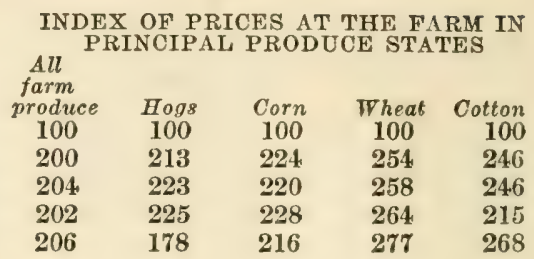

It will be seen that the farmer enjoyed prices equivalent to and higher than the general level up to the last six months. He is now, however, falling behind in some important products. Unlike the industrial workers, he is unable to demand an adjustment of his income to the changed index of living.

For the moment, what I wish only to establish is that the farmer's prices are not based upon any conception of costs of production, but upon forces in which he has no voice. He can never organize to put his industry on a "cost plus" basis as industrial producers do, and a remedy must be found elsewhere.

As stated, the margin between the farmer and consumer falls into two divisions-one of which predominantly affects the farmer and the other the consumer. It is really the wholesale prices that govern the farmer, rather than retail prices, for it is in wholesale prices that the farmer competes with the world. As the prices paid by the wholesaler are mostly fixed by overseas trade at the datum point on the Atlantic seaboard o: in Europe, then if the margins between the wholesaler and the farmer are unduly large, or increase, it is mostly to the farmer's detriment. For instance, as the price of his wheat in normal times is made in Liverpool, any increase in handling comes out of the farmer's price. Likewise, as the wholesale butter price is made 
by the import of Danish butter into New York, any increase in the numbers or charges between our farmer and the wholesale buyer comes to a considerable degree out of the farmer.

As the datum point of determining prices is at the wholesaler, the accretion by the charges for distribution from that point forward to the consumer's door will not affect the farmer, but does affect the consumer. When competition decreases through shortage the consumer pays the added profits of these trades.

Studies of the cost of our distribution system, made by the Food Administration during the war, established two prime conditions. The first is that the margine between our farmers and the wholesaler in commoditics -other than grain in some instances-are, even in normal times, the highest in any civilized state-fully twenty-five per cent. higher than in most European countries. The expensiveness of our chain of distribution in most commodities in normal times, as compared with Continental countries, is due partly to the wide distances of the producing areas from the dominating consuming areas, but there are other contributing forces that can be remedied.

In Europe the great public markets in the cities bring farmer and consumer closely together in many commodities, but in the T'nited States the bulk of products are too far afield for this. The farmer must market through a long chain of manufacturers, brokers, jobbers, and wholesalers with or without their own distribution system, who must establish a clientele of direct retailers; and thus public markets, except in special locations and in comparatively few commodities, have 
not been successful. Another major factor in our costs of distribution is the increasing demand for expensive service by our consumers. There are many other factors that bear on the problem and the economic results of our system which are discussed, together with some suggestions of remedy, later on.

The second result of these studies was to show the great widening of this margin during the war. During the year of the Food Administration in active restraint on this margin there was an advance of six points in the wholesale index while the farmer's index moved up twenty-five points. Both before and after that period the two indexes moved up together. The same can be said of the margins between the wholesaler and the consumer. Taking the period of the war as a whole, the margin between the farmer and consumer has widened out to an extravagant degree.

A good instance of a movement in margins is shown in flour in 1917. The farmer's average return for wheat of the 1916 harvest, as shown by the Department of Agriculture, was about $\$ 1.42$. As about four and one half bushels of wheat are required to make a barrel of flour, the farmer's share of the receipts from this harvest was about $\$ 6.40$ per barrel. In 1917 , before the Food Administration came into being, flour rose to $\$ 17.50$ per barrel to the consumer, or, at that time, a margin of eleven dollars per barrel. During the administration the farmer received an average of about two dollars for wheat at the farm, or about nine dollars out of a barrel of flour. The consumer paid $\$ 12.50$, the margin being about $\$ 3.50$ per barrel. This increase in margins shows vividly in the higher priced 
foods; for instance, pork products. If we take hogs at the railway station over the great hog states contiguous to Chicago as a basis, we find:

\begin{tabular}{|c|c|c|c|}
\hline & \multicolumn{3}{|c|}{ SIX MONTHS } \\
\hline & 1914 & 1919 & 1920 \\
\hline $\begin{array}{l}\text { per } 100 \text { pounds................... } \\
\text { Price of cured products to con- }\end{array}$ & $\$ 7.45$ & $\$ 16.27$ & $\$ 15$ \\
\hline $\begin{array}{l}\text { sumer from } 100 \text { pounds hogs } \\
\text { Margin between farmer and }\end{array}$ & 18.97 & 37.33 & 37. \\
\hline & 11.52 & 21.06 & 22.34 \\
\hline
\end{tabular}

Thus, while the farmer has gained about $\$ 7.92$ in his price, the margin has increased by $\$ 10.82$ to the consumer, and incidentally, during the last year since food-control restraints were removed, the consumer has paid thirty cents more while the farmer got ninety cents less. These instances could be greatly multiplied.

It is unfortunate that our national statistics do not permit a complete analysis of the distribution of margin between all the various groups in the chain between the farmer and consumer in different commodities. It would be helpful if we could take the farmers, railways, manufacturers, wholesalers, and retailers, and determine what proportion each receives.

These margins between farmer and consumer are made up of a necessary chain of charges for transport, storage, manufacture, and distribution. The great majority of citizens who are engaged in the processes that go to make up this portion of food costs are employed in an obviously essential cconomic function and they do not approach it in a spirit of criminality, but as a very necessary, proper, and honorable function. They have, since the European war began, rather overenjoyed the result of economic forces that were not of 
their own creation. That a considerable margin is necessary to cover the legitimate costs of and profits on distribution is obvious. The only direction of inquiry is how they can be legitimately minimized.

These margins, starting from the unduly high expense of a faulty system, have increased not only legitimately, due to increased transportation, labor, rent, taxes, and increased interest upon the large capital required; but they have, except during the period of control, increased unduly beyond these necessities. There are two general characteristics of this margin that are of some interest. In the first instance, all of the transport, storage, manufacture, and handling is conducted upon a basis of cost plus either fixed returns or, as is more usually the case, a percentage of profit upon the whole cost of operation. Any distributing agency ceases to operate when it does not secure costs and a profit. Consequently, all these links put up a resistance to a curtailment of the margin which the farmer is unable, cxcept by absolute exhaustion, to do against reduction of his price levels. If rapid falls in food prices occur, the farmer, at least in the first instance, has to stand most of the fall because he cannot quit.

The farmer's costs of production relate to a period long prior to the fall. Thus, if wages are due to fall as a result of a fall in food prices the farmer is always selling on the old basis of his costs. The farmer has but one turnover in the year. The middleman has several, and can thus adjust himself quickly.

Second, the custom of many of these businesses is to operate upon a percentage of profit on the value of the 
commodities handled, even after deducting all their increased costs, interest, or other charges. When we have rising prices, therefore, a doubling of prices, for instance, tends to double profits on the same volume of commodities handled. In a rising market competitive pressures are much diminished and the dealer can assess his own profits to greater degree than usual. Whils the packers make a profit of, say, two cents on the dollar value of commodities, it represents double the profit per pound over pre-war, even after allowing such items as interest on the larger capital involved.

Aside from the necessary rise in the margin that has grown out of the rise in cost of labor, rent, and so on, from inflation and world shortage, there are some causes which have accumulated to increase the margins between the farmer and the wholesaler and the wholesaler and the consumer that could be greatly mitigated.

During the war, in order to restrain wild greed and profiteering in the then existing unlimited demand, margins between purchase and sale in the different manufacturing and handling trades were fixed in all the great commodities-iron, steel, cement, lumber, coal, and foodstuffs. The first task of the war was to secure production, and the margins were therefore fixed at such breadth as would allow the smaller high-cost manufacturer and the smaller dealer to live. Otherwise the smaller competitors would have been extinguished, production would have been lost, and, worse yet, the larger low-cost operator would have been left with much inflated monopoly. The excess-profits tax was levied as a sequent corrective to this necessary first step, so as to take the undue profits of the large producer back to 
the public. It was a wise war measure, but the moment restraints on profits were taken off and there was a free and rising market ahead, the tax was added to prices by all the participants and passed on to the consumer, or deducted from the farmer when world levels crowded his prices down. It should have been repealed at the time the controls were abandoned, but our legislatures have been busy with other things, and in the meanwhile in food it not only increases the margin between the farmer and the consumer but tends, as stated above, to come out of the farmer to a large degree. It has other vicious results in that it stimulates dealers and manufacturers to speculate their profits away in unsound business, rather than to pay them to the Government. It does sound well to tax the great manufacturers, but to make them the agency to collect taxes from the population is not altogether sound government.

It is a very important tax to the Government, bringing as it does over a billion a year, and a place to put this load is not to be found easily.

The income tax does not have so malign an effect, for it comes to a great extent from the individual and not from business. The present method of income tax, however, has some weaknesses. The same levy is made upon earned incomes as upon those that are unearned. The $\operatorname{tax}$ on earned incomes tends in certain cases to be passed on to the consumer or deducted from the farmer, and, besides, it is not just that a family living by giving productive service to the community should pay the same as a family that contributes nothing by way of effort. A stiff tax on these latter might send them to work, and certainly induce economy. Moreover, the 
earner of income must provide for old age and dependents while the unearned-income taxpayer has this already. Altogether, it would seem the part of wisdom at least to increase the income tax on the larger unearned income and decrease it on the earners. It is argued that this drives great incomes to evasion by investment in tax-free securities, which is probably true. We need more comparative figures than the Treasury statistics yet show to answer this point. In any event, relief to the earner would free his savings to invest in taxable securities, and we need of all things to stimulate the initiative of the saver. Income taxes, except when too high on earned incomes, do not destroy initiative, and every other government has, in taxing, recognized the essential difference between earned and unearned incomes. This distinction would generally relieve the range of smaller incomes, for they are mostly earned.

The inheritance-tax field has not been fully exploited as yet. It cannot be deducted from either farmer or consumer, it does not affect the cost of living, it does not destroy initiative in the individual if it leaves large and proper residues for dependents. It does redistribute overswollen fortunes. It does make for equality of opportunity by freeing from the dead hand control of our tools of production. It reduces extravagance in the next generation and sends them to constructive service. It has a theoretic economic objection of being a dispersal of capital into income at the hands of the Government, but so long as the Government spends an equal amount on redemption of the debt or productive works even this argument no longer stands. 
We may need to come to some sort of increased consumption taxes in order to lift that part of excess profits and tax on earned income that cannot be very properly placed elsewhere. When it comes it should lie on other commodities than food, except perhaps sugar, one half of which is a luxury consumption. The ideal would be for it to be levied wholly on non-essentials in order that it should be a burden on luxury and not on necessity. This is no doubt difficult to classify. Jewelry and furs are easy to class, but where necessity leaves off and luxury begins in trousers is more difficult to determine.

It requires no lengthy economic or moral argument as a platform for denunciation of all waste and useless expenditure. Some sane medium is needed between comfort and luxury. Failing definition, and objection to blue laws, the theme must be taken into the area of moral virtues and becomes a proper subject for the spiritual stimulations of the church. There is a psychology in luxury wherein we all buy high-priced things because they are high-priced, not because they add comfort-and this has contributed also to our high cost of living-for those who do it drive up prices on those who try to avoid it. From an economic point of view the only recipe is taxation as a device to make it expensive.

More constructive than increasing taxes is to take a holiday on governmental expenditures and relieve the taxpayer generally. If we could stave off a lot of expensive suggestions for a few years and secure more efficiency in what we must spend, our people could get ahead with the process of earning something to tax. 
It would at least be comforting to this great farming and business community.

There is a great weakness in our present railway situation bearing upon the farmer and consumer. Everyone knows of the annual shortage of cars during the crop-moving season. Few people, however, appreciate that this shortage of cars often amounts to : stricture in the free flow of commodities from the farmer to the consumer. The result is that the farmer, in order to sell his produce, often unknown to himself makes a sacrifice in price in local glut. The consumer is compelled at the other end to pay an increased price for foodstuffs due to the shortage in movement. The constant fluctuations in our grain exchanges locally or generally from this cause are matters of public record almost monthly. On one occasion a study was made under my administration into the effect of car shortage in the transportation of potatoes, and we could demonstrate by chart and figure that the margin between the farmer and the consumer broadened 100 per cent. in periods of car shortage. Nor did the middleman make this whole margin of profit, because the was subjected to unusual losses and destruction, and took unusual risks in awaiting a market. The same phenomenon was proved in a large way at the time of acute shortage of movement in corn and other grain.

The usual remedy for this situation is insistence that the railways shall provide ample rolling stock, trackage, and terminals to take care of the annual peak load. We have fallen far behind in the provisions of even normal railway equipment during the war, and an additional 500,000 cars and locomotives are no doubt 
needed. Above a certain point, however, this imposes upon the railways a great investment in equipment for use during a comparatively short period of the year when many commodities synchronize to make the peak movement. The railways naturally wish to spread the movement over a longer period. The burden of equipment for short-time use will probably prevent their ever being able to take entire care of the annual delays in transport and stricture in market, although these can be greatly minimized.

There is possible help in handling the peak load by improving the waterways from the Great Lakes to the Atlantic seaboard by way of the St. Lawrence River, so as to pass full seagoing cargoes. It has already been determined that the project is entirely feasible, and at comparatively moderate cost. The result would be to place every port on the Great Lakes on the seas. Fifteen states contiguous to the Lakes could find an outlet for a portion of their annual surplus quickly and more cheaply to the overseas markets than through the congested Eastern trunk rail lines. It would contribute materially to reduce this effectual stricture in the free flow of the farmer's commodities to the consumers.

Of far greater importance, however, is the fact that the costs of transportation from the Lake ports to Europe would be greatly diminished, and this diminished cost would go directly into the farmer's pockets. $\mathrm{It}$ is my belief that there is a saving here of five to six cents a bushel in the transportation of grain. Althougin a comparatively small proportion of our total grain production flows to Europe, I believe that the economic lift on this minor portion would raise the price of the 
whole grain production by the amount saved in transportation of this portion of it. The price of export wheat, rye; and barley-sometimes corn-usually hogs -in Chicago at normal times is the Liverpool price, less transportation and other charges, and if we decrease the transport in a free market the furmer should get the difference.

Not only should there be great benefits to the agricultural population but it should be a real benefit to our railways in getting them a better average load without the cost of maintaining the surplus equipment and personnel necessary to manage the peak load during the fall months. It has been computed that the capital saving in rolling stock alone would pay for the entire cost of this waterway improvement over a comparatively few years. The matter also becomes of national importance in finding employment for the great national mercantile fleet that we have created.

Another factor in transportation bearing upon the problem of marketing is the control by food manufacturing and marketing concerns of refrigeration and other special types of cars. This special control has grown up largely because, owing to seasonal changes in regional occupation for these cars over different parts of the country, no one railway wished to provide sufficient special cars and service for use that may come its way only part of the year. The result has been to force the building up of a domination by certain concerns which control many of the cars and stifle free competition. Much the same results have been attained by special groups in control of stockyards and, in some cases, of elevators. Where such formal or informal 
monopolies grow up, they are public utilities and if the farmer is to have a free market they must be replaced by constructive public service.

Every impediment to free marketing of produce either gives special privileges or increases the risks which the farmer must pay for in diminished returns. We have some commodities where manufacture has grown into such units that these units exert such an influence that they consciously or unconsciously affect the price levels of the farmer's produce. When a few concerns have the duty of manufacturing and storing the seasonal reserves of a single commodity they naturally reduce prices during the heavy-production season and increase them in the short season as a method of diminishing their risk and increasing profits. Moreover, their tendency is often to sell the minor portion of their product that goes for export at lower than the domestic price in order to dispose of it without depressing local prices. They do not need to conspire, for there can be perfectly coincident action to meet the same economic currents. Such coincidence has much greater possibilities of general influence with a few concerns in the field than if there were many.

The experience gained in the Food Administration on these problems during the war led to the feeling, expressed at that time, that such business should be confined to one line of activity, just as we have had to confine our railways, banks, and insurance companies. This is useful to prevent reliance being placed upon the profits of alternative products when engaged in stifling of competition, through selling below cost on some other item. Even this restriction may not prove to be 
sufficient protection to free market by free competition.

I am not a believer in nationalization as the solution to this form of domination, but I am a believer in regulation, if it should prove necessary. If experience. proves we have to go to regulation, it is my belief that it should be confined to overswollen units and that the point of departure should not be the amount of capital employed but the proportion of a given commodity that is controlled. The point of departure must depend upon the special commodity and its ratio to the whole. When such a concern obtains such dimensions that it can influence prices or dominate public affairs, either with deliberation or innocence, then it must be placed under regulation and restraint. Our people have long since realized the advantage of large business operation in improving and cheapening the costs of manufacture and distribution, but when these operations have become so enlarged that they are able to dominate the community it becomes a social necessity that they shall be made responsible to the community.

The test that should apply, therefore, is not the size of the institution or the volume of capital that it employs, but the proportion of the commodity that it controls in its operations.

It is my belief that if this were made the datum point for regulation, and if regulation were made of a rigorous order, this pressure would result in such business keeping below the limit of regulation. Thus the automatic result would be the building up of a proper competition, because men in manufacturing would rather conduct a smaller business free of governmental regulation than enjoy large operations subject to govern- 
mental control. There are probably only a very few concerns in the United States that would fall into this category and they should be glad of regulation in order to secure freedom from criticism.

There are three kinds of speculation and profiteering in the food trades. The first is of the inherent or speculative character of foodstuffs due to their seasonal nature. The farmer, more by habit than necessity, usually markets the bulk of his grain in the fall. By necessity he must market his animals at certain seasons, for they must be bred at certain seasonable periods, they must be fed at certain seasons, and thus come to market in waves of production larger than the immediate demand. In perishables he must market fairly promptly, as he cannot himself maintain necessary special types of storage. Thus the dealer must speculate on carrying the commodities for distribution during the period of short production, while the farmer markets in time of surplus production.

While full competitive conditions might reduce the charges for this hazard there is a possibility of reducing the hazard by better organization and consequently the charge for the hazard that is now debited to the farmer. It is worth an exhaustive national investigation to determine whether an extension of a system of central markets would not afford great help. I do not mean the extension of our so-called exchange dealing in local produce but the creation of great central exchange markets with responsibilities for service to the entire people. This help arises in two ways. The first is the hourly determination of price at great centers that all may know, and thus the farmer protects himself against 
local variations and manipulation. The second is a system of forward contracts through such a market between farmer and consumer on standardized commodities. Such contracts in effect remove the necessity of a speculative middleman. This system exists in grain and cotton and in its processes eliminates a large part of the hazard and carries the commodity at the lower rate of interest.

The present trouble with the system of future contracts is that it lends itself to manipulation, but I believe this could be eliminated.

If we take the case of potatoes, here is an unstandardized seasonal commodity, with no national market and therefore no established daily price as a datum point. A grower in Florida, Maine, or Wisconsin, through a local agent or through local sale, consigns potatoes to Pittsburgh because a larger price is reported there than in Chicago. The grower can usually make no actual sale to an actual retailer or wholesaler at destination because the buyer has no assurance of quality. Coincident shipment from many points to a hopeful market almost daily produces a local glut at receiving points somewhere in the country. Often enough the shipper gets no return but a bill for freight, and the perishables sometimes rot in the yards.

If potatoes were standardized and sold on contract in national market, protected from manipulation, three things would result. First, there would be a daily national price known to growers. Second, by the sale of a contract for delivery the grower would be assured of this price. Third, the contract and directions for shipment would flow naturally to the distributor where 
the potatoes were needed, and thus the present fearfully wasteful system would be mitigated.

Potatoes would be a most difficult case to handle; dried beans, peas, even butter, and cheese would be easier. I am not advocating widespread dealing in futures, but short contracts giving time for delivery would probably greatly decrease the margin between farmer and local distributor by saving great wastes in transport, spoilage, and manipulation.

The second class of speculation is one largely of the war as a period of rising prices growing out of inflation, and so forth. It lies in the marking up of goods on the shelf to the level of the rising daily market. This marking up has been one of the large factors in increasing the margin during the war. No better example exists than the rise of flour during the 1916-1917 harvest year, referred to elsewhere. We shall have a remedy for this the moment the tide of inflation turns. The farmer and consumer cannot, however, expect that they will get even, during such a reverse period, for their losses on the rise, because the trades have too great an individual power of resistance against selling goods at a loss. Anyway, the marking up of goods will ceasc when prices cease to rise-and there is a limit.

The third class of speculation is wholly vicious. That is the purchase of foodstuffs in times of rising economic levels, sheerly for the rise in price or the deliberate manipulation of markets during normal times. These operations are against the common welfare; they can find no moral or economic justification. They are not to be reached by prosecution; they must be reached by prevention. Our great boards of trade in fine patriotic 
spirit proved their ability during the war to control deliberate manipulation of grain and other futures. Both of the two latter types of speculation are an impediment to free markets and they become an unnecessary charge on the margin.

There can be no question of the improvement in position of both farmer and consumer in cases where coöperative marketing can be organized. The high development of coöperative citrus-fruit marketing has resulted in lower average prices to consumer, better quality and better return to the grower. Here is a case of scientific distribution lamentably absent in many other commodities. There are other specialized products to which it could be well extended. To reach its best development it should have parallel coöperative development among consumers as discussed elsewhere.

There are many ways of assisting the agricultural industry not pertinent to this discussion on the cost of distribution. They do demand inquiry and public illumination; most of them do not demand legislation so much as public education and consideration when legislating on other subjects. Our agricultural interests also need a foreign policy. For instance, during the last month there has been a consolidation of control of buying in world markets by the European governments. How far it may be extended in its policies is not clear. Nevertheless, a combination of importers in all Europe under government control could make the prices on every farm in the United States.

As the datum point of price determination is the wholesaler's market, the accretions of charge for distribution from that point forward, the economy or ex- 
travagance in these costs, are of primary interest to the consumer. The same phenomena-of marking up goods on the shelf, calculating profits not on commodities but on dollars handled, a minor amount of vicious speculation, the passing on of excess-profits tax-are present in these trades during the past years. A much more pertinent phenomenon in unduly increasing their margins is the increasing demands of the consumer as to service. Several deliveries daily, purchases on credit, the abandonment of the market basket in favor of the telephone have many costs. One of them, much overlooked, is that customers must always have first quality when they buy blind over the telephone, and the seconds and thirds, of equal food value in many commodities, go to waste and are added to the price of the firsts. That there are some people in the United States who want to buy sanely is evidenced by the 400 per cent. increase in cash-and-carry shops, which do business on approximately sixty per cent. of the cost of the delivery-and-credit shops.

There are also many people in the final stages of distribution. One city in the United States has one meat retailer for every 400 inhabitants; it would be equally well served with one dealer to every 1,200. The result is high margin to the retailers and no out-of-the-way income to any of them. There is no very immediate remedy for this. One possibility is an extension of coöperative buying by consumers. It has proved a great success abroad. It is not socialism, for it arises from voluntary action and initiative among the pcople themselves.

There is now a tendency to ill balance between the 
agricultural and general industry. For many years we were large exporters of food and importers of manufactured goods. We gradually imported mouths, manufactured our own goods, and just as rapidly diminished our food exports. Up to the point where we consumed our own food and manufactured our own goods it has been a great national development.

Our annual exports of food decreased during the past twenty-five years from some fifteen million tons to about six millions just before the European war. In the meantime we increased import of such commodities as sugar, rice, vegetable oils, until our net exports were about five million tons. Of all kinds of food exported this probably represents the decreased exports of from twenty-five to thirty per cent. of our production down to five per cent. of it.

During the war we gave special stimulus to food production and produced greater economies in consumption, so that these later years somewhat befog the real current, for our agricultural surplus in normal years is really very small. During the war and since, we have given great stimulus to our manufacturing industries. If we shall continue to build up our manufacturing industries and our export trade without corresponding encouragement to agriculture we shall soon have more mouths in our country than we can feed on our own produce. We shall, like the European states which have devoted themselves to industrial development, ultimately become dependent upon overseas food supplies. If we examine their situation we find the very life of their people is thus dependent upon maintaining open free access to overseas markets. 
From this necessity have grown the great naval armaments of the world, and the burden they imply on all sections of their population. Such nations, of necessity, have engaged in fierce competition for markets for their industrial products. Thus they built up the background of world conflicts. The titanic struggles that have resulted have endangered the very lives of their people by starvation. Their war tactics have, in large degree, been directed to strangle food supplies. One other result of this development is the terrible congestion of populations in manufacturing areas, with all the social and human difficulties that this implies. There is a jeopardy in industrial over-development which has received too little attention because the world has experienced it only during the past eighteen months. In times of industrial depression or great increase in the cost of living, whether brought about by war or by the ebb and flow of world prosperity, these populations, oppressed with misery, turn to political remedies for matters that are beyond human control. They naturally resent the lowering of their standards of living, and they inevitably resort to industrial strife, to strikes and disorder. Theirs is the breeding ground of radicalism-for all such phenomena belong to the towns and not to the country.

By and large, our industries are now in a high state of prosperity. More favorable hours, more favorable wages, are to-day offered in industry than in agriculture. The industries are drawing the workers from our farms. If this balance in relative returns is to continue we face a gradual decrease in our agricultural productivity. If we should develop our industrial side 
during the next five years as rapidiy as we have during the past five years we shall by that time be faced with the necessity to import foodstuffs to supplement our own food supplies.

Some economists will argue, of course, that if wc can manufacture goods cheaper than the rest of the world and exchange them for foodstuffs abroad we should do so. But such arguments again ignore certain fundamental social and broad political questions. These dangers have become more emphasized by experience of the war. From dependence on overseas supplies for food we shall, by the very concern that will grow in the public mind as to the safety of these supplies, soon find ourselves discussing the question of dominating the seas. Our international relations will have become infinitely more complex and more difficult. Unless the League of Nations serves its ideal we shall need to burden ourselves with more taxation to maintain great naval and military forces.

But of far more importance than this is that the social stability of our country, the development of our national life, rests in the spirit of our farms and surrounds our villages. These are the sources that have always supplied our country with its true Americanism, its new and fresh minds, its physical and its moral strength. Industry's real market is with the farmer by the constant increase of his standard of living. We want our exports to grow in exchange for commodities we need from abroad, but we want them to grow in tune with our social and political interests, and to do so they must grow in step with our agriculture.

In conclusion, we are in a period of high inflation and 
shortage of world production, and consequent abnormal prices. The tide is likely to turn almost any time. Some of the outrageous margin between the farmer and consumer will be lessened by the turn in the tide itself, for it will eliminate the marking up of goods and the opportunity of vicious speculation. The dangers of the turn are twofold. First, that unless we constructively remedy the unnecessary margin between the farmer and the wholesaler the farmer will receive the brunt of the fall long before the supplies he must buy and labor he must employ will have fallen into step. It will bring to him the greatest suffering in the community. The farmer's position can be remedied by better distribution of the tax load, by improvement in our transportation system, by getting our markets free of impediments to free flow of competition, and by constructive improvement in our whole distribution system. The consumer will get relief from deflation, improvement in world production, and by eliminating the same wastes and unnecessary costs in our distribution system.

The second danger is that deflation itself will take place without constructive consideration. Great wisdom will be required on the part of our Government in its great control of credit that it shall take place progressively and with care, in order that there shall be no sudden breaks, with their resulting demoralization, unemployment, and misery.

We require a careful balance of general industry to agriculture. We cannot afford to build this nation into an industrial state dependent upon other lands for its food supply. We want our industries to grow, but we want agriculture to grow in pace with them. Many of 


\section{AGRICULTURAL READJUSTMENT 265}

our farmers made great sacrifices in the war; they do not want to be coddled in peace; but they must have an equality of opportunity with all the other elements in the country. 

THE FARMER AS A SCIENTIST 



\section{XX}

\section{TRIUMPHS OF SCIENTIFIC AGRICULTURE *}

\section{George W. Fiske}

EFficiency is everywhere demanded by the spirit of our times. We are living in an age that does things. Whatever the difficulties, it somehow gets things done. It brings to pass even the seemingly impossible. Are there mountains in the way? It goes over, under, or through. - There are no mountains! Is there an isthmus, preventing the union of great seas and blocking commerce? It erases the isthmus from the world's map.-There is no isthmus! The masterful time-spirit has little patience with puttering inefficiency. It expects every man to pull his weight, to earn his keep, to do his own task, and not to whimper.

Our cities are hives of efficiency, cruel efficiency often. With new pace-makers every year, the wheels of industry speed ever faster, raising the percentage of effectiveness, per dollar of capital, and per capita employed. Hundreds at the wheels, with scant nerves, fail to keep the pace; and the race goes by them. But the pace keeps up. Other workmen grow more deft and skilful. The product is both cheapened and perfected. The plant becomes more profitable, under fine executive efficiency. The junk-heap grows apace: Out goes every obsolete half-success. In comes every new machine

* From "The Challenge of the Country," by permission of the publishers, the Aseociation Press. 
which reduces friction, doubles results, halves the cost of maintenance, and swells dividends. Surely efficiency is the modern shibboleth.

Here is the new Tungsten electric lamp, which uses half the current, at low voltage, but doubles the light; the very dazzling symbol of efficiency. How it antiquates the best Edison lamp of yesterday! Yet the 'Tungsten becomes old-fashioned in a year. It is too fragile and is speedily displaced by the improved Mazda.

But city life has no monopoly on efficiency. In fact we do not find in the mills or factories the best illustrations of modern effectiveness. We have to go back to the soil. Agriculture has become the newest of the arts, by the grace of modern science. To make two blades of grass grow where one grew before is too easy now. Multiplying by two is small boys' play. Burbank has out-Edisoned Edison! He and other experimenters in the scientific breeding of plants and animals have increased the efficiency of every live farmer in the land, and have added perhaps a billion dollars a year to the nation's wealth.

They have not yet crossed the bee and the firefly, as some one has suggested, to produce an illuminated bee that could work at night by his own light. Nor have they produced woven-wire fences by crossing the spider and the wire-worm! Not yet; but they have done better. By skillful cross-breeding, they have raised the efficiency of the sugar beet from 7 per cent. to 15 per cent. sugar. They have produced hardy, seedless oranges, plums, apples, and strawberry plants which will stand the climate of the frozen North. They have 
developed fine, long-stapled cotton, high-yielding cereal grains, and mammoth carnations and chrysanthemums. They have produced the wonderberry, the Wealthy Apple, and the Burbank Potato. They have developed flax with 25 per cent. more seed. And the "Minnesota Number Thirteen Corn," so hardy and sure, has carried the cornbelt in three great states fully fifty miles further to the north, with its magnificent wake of golden profits. No wonder America feeds the world. Such is our splendid Yankee genius for efficiency. It is the master-spirit, the ruling genius of our age; and it shows itself best on our fields and prairies. Other nations compete fairly well with our manufactures. They outstrip us in commerce. But they are hopelessly behind our American agriculture. The farm products of this country amounted in the year 1910 to almost nine billion dollars. The corn crop alone was worth a billion and a half; enough to cancel the entire interest-bearing debt of the United States, buy all of the gold and silver mined in all the countries of the earth in 1909, and still leave the farmers pocketmoney.*

In all fairness it must be said, the modern gospel of progressiveness has not been everywhere accepted, far from it. Plenty of farmers, doubtless the majority, are still following the old traditions. Country folks as a rule are conservative. They like the old ways and are suspicious of "new-fangled notions." Director Bailey of Cornell enjoys telling the comment he overheard one day from a farmer of this sort. It was after he had been speaking at a rural life conference, doubt-

\footnotetext{
* Report of U. S. Sec. of Agri. for 1910, p. 11.
} 
less proposing various plans for better farming, which differed from the honored superstitions of the neighborhood. A stolid native was overheard saying to his neighbor, "John, let them blow! They can't hurt me none." He prided himself on being immune to all appeals at such a rural life revival.

Such a man is very common among the hills, and wherever the soil is poor; but he is beginning to feel lonesome in really prosperous rural communities, for the new agriculture is fast winning its way. That is, the application of science to agriculture has proved its efficiency by actual tangible results. A farmer may be so superstitious as to begin nothing on a Friday, nor butcher during a waning moon for fear his meat will shrink, nor use an iron plow for fear it may poison the soil! But when his neighbor by modern methods adds 50 per cent. to his crop, he knows there must be something in it. 'The new theory he always greets with "I don't believe it!" but the knock-down argument of facts compels his reluctant faith. Soon he gives the new heresy a trial himself; and success makes him a convert to the new gospel.

An experience like this is a serious thing for a hidebound conservative, long wedded to old methods. It means that "the former things are passed away and behold all things are become new." He loses his superstitions as he discovers the laws of cause and effect. He gradually concludes that farming is not a matter of luck but largely a matter of science; that it is not merely tickling Dame Nature till she grudgingly shares her bounties, but that it is a scientific process, the laws of which may be discovered. This means 
mental growth for the farmer, the stimulus of many new ideas which bring wider horizons and a larger life; and incidentally a heightened respect for his own life-work.

'The old-fashioned farmer, particularly in America where methods have been so wasteful because of the cheapness of land, has planted and harvested just for the season's returns, with little regard for the future. The modern farmer, self-respecting and far-sighted, plans for the future welfare of his farm. He learns how to analyze and treat his soil and to conserve its fertility, just as he would protect his capital in any business investment. Scientific management and farm economy are taking the place of mere soil-mining and reckless waste. The best farmers plan to leave their farms a little more fertile than they found them. Good authorities in rural economics assert that if depletion of soil fertility were taken into account, the wasteful methods of American agriculture in the past, though producing apparently large returns, have actually been unprofitable. So long as new land could easily be obtained from the government for a mere song and a few months' patience, the pioneer farmer was utterly careless in his treatment of the soil. He moved from state to state, skimming the fat of the land but never fertilizing, following the frontier line westward and leaving half-wasted lands in his trail.

It was really a blessing to the land when the scarcity of free homesteads brought this wasteful process towards its end. When new lands became scarce, the farms of the Middle West increased in value. For twenty years farm values have been rising steadily, with two evident results: intensive farming and speculation. 
The demoralizing effects of the latter are at once apparent. It was a sad day when the prairie farmer ceased to think of his farm as a permanent home, but as a speculative asset. But it was a good day for the business of farming when the farmer discovered the need of more careful, intensive cultivation to keep pace with rising values. This marks the beginning of scientific thoroughness and efficiency in our tilling of the soil.

Just then something very timely happened. The modern period of American agriculture really dates from 1887, when Congress, by the Hatch Act, established the first national system of agricultural experiment stations in the world. Previous to this date there had been a few private and state enterprises; but this Act of Congress established at public expense an experiment station in every state and territory. The vast usefulness of this movement in developing a real science of agriculture is evident from this paragraph from the law :

Sec. 2. That it shall be the object and duty of said experiment stations to conduct original researches or verify experiments on the physiology of plants and animals; the diseases to which they are severally subject, with the remedies for the same; the chemical composition of useful plants at their different stages of growth; the comparative advantages of rotative cropping, as pursued under the varying series of crops; the capacity of new plants or trees for acclimation; the analysis of soils and water; the chemical composition of manures, natural or artificial, with experiments designed to test their comparative effects on crops of different kinds; the adaptation and value of grasses and forage plants; the composition and digestibility of the different kinds of food for domestic animals; the scientific and economic questions involved in the production of butter and cheese, et cetera.

As a result of this and later laws, over three millions of dollars are now spent annually, by the national and state governments, to support experiment station work. 
Over a thousand men are employed in the investigations and their publications cover practically the whole range of the science and art of agriculture. About five hundred separate bulletins are issued each year, which may be obtained free on application.

This great chain of experiment stations is working wonders. In coöperation with the agricultural colleges and the U. S. Department of Agriculture, they are raising agriculture to scientific levels. They are, by their laboratory work, doing the farmer's experimenting for him and doing it better and with greater certainty. Thus they are eliminating much of the uncertainty and "luck" from farming which has been its curse and discouragement. And thus they are equipping the farmor to cope more effectively with the difficulties of nature and to put up a more confident fight with stubborn climate and fickle weather, because he knows the scientific points of the game.

The opening of rich prairie lands to cultivation, with the marvels of extensive agriculture, is a wonderful story. But intensive farming has its own triumphs, though they may be less spectacular. There is something that wins our respect in the careful, thorough methods of European agriculture, by which whole nations are able to make a living on tiny farms by intensive farming. Tilling every little scrap of ground, even roadside and dooryard, and guarding the soil fertility as the precious business capital of the family, it is wonderful how few square rods can be made to sustain a large family.

Frugality is not attractive to Americans, especially the European type which often means peasant farming, 
and a low scale of living. We are discovering, however, the vast possibilities of farm economy and intensive cultivation. Professor Carver says :

Where land is cheap and labor dear, wasteful and extensive farming is natural, and it is useless to preach against it. . . . . We always tend to waste that which is cheap and economize that which is dear. The condition of this country in all the preceding periods dictated the wasteful use of land and the economic use of labor, as shown by the unprecedented development of agricultural machinery. But as land becomes dearer, relatively to labor, as it inevitably will, the tendency will be equally inevitable toward more intensive agriculture, that is, toward a system which produces more per acre. This will follow through the normal working of economic laws, as surely as water will flow down hill.

It is wonderful what can be accomplished by intensive cultivation. If the old New England orchards were given as thorough care and treatment as the scientifically tended and doctored apple trees of Oregon, the results would surprise the oldest citizen! Conserving moisture and keeping the soil clean from weeds is worth all the painstaking care it requires. 'The renovation of the soil by regular fertilizing is a lesson the wasteful West is slowly learning, coupled with scientific schemes of crop rotation to conserve the soil's quality. Farmers are astonishingly slow to adopt these methods, however, thinking that they know best the needs of their own soil. The North Dakota experiment station is inducing farmers to adopt their advice as to seed selection and crop rotation with the promise to set aside five acres for experimentation in accordance with the advice given. This is extremely wise policy. Doubtless, if directions are faithfully followed, the contrast with the rest of the farm will be highly favorable to the five-acre lot and agricultural progress will win out. In the earlier pages we have already alluded to this 
fascinating subject as an illustration of modern efficiency in country life. Four years ago Assistant Secretary Hays of the Department of Agriculture asserted that scientific breeding of better stock and plant life was netting this country a billion dollars a year, of the total agricultural production of seven and a half billions in 190\%.* In 1910 the total reached about nine billions and it is probable that scientific agriculture was the main cause of the great increase rathe: than additional acreage.

One of the wonders of modern science is this story of the development of new plant species and improvement in the best of the old, by the skillful processes of plant breeding. Notable also has been the improvement in American horses, cattle, swine, and poultry, developed by the same scientific principles. Projected efficiency, or breeding power to beget valuable progeny, is the central idea. Simple selection is the method. Out of a large number of animals the phenomenal individual is selected for his notable capacity for reproducing in his offspring his own desirable characteristics. Thus the best blood is multiplied and the less desirable is discarded. Sometimes by close inbreeding the eugenic process has been hastened. In this way scientific stock raisers have been able practica!ly to make to order animals with any desired quality. For instance, the great demand for bacon in England has been met by a masterly bit of agricultural statesmanship, for which Mr. John Dryden, chief of the Canadian Agricultural Department, is responsible. After careful study and experiment, the Yorkshire and Tamworth breeds of \# "Brains That Make Billions," W. M. Hays, in the Saturday Evening
Post, Aug. 29. 1908 
hogs were crossed and a special breed developed especially valuable for bacon with exceptionally long sides of uniform thickness and with alternating layers of fat and lean. Selected bacon made to order!

New breeds of sheep have been developed which have combined phenomenal wool-producing power with superior meat production; similarly short-horn cattle with great milk-giving capacity and beef production; and more remarkable still have been the results in horse breeding. In spite of all the motor-cycles and automobiles, the horse is becoming more and more useful, because more highly civilized and specialized. The breeders know how to build up horse-flesh to suit your special needs for draft horse, family horse, trotter, or pacer, with any desired form, proportions, or talent, almost as accurately as a druggist compounds prescriptions! The wonderful possibilities involved challenge our imagination. Among the results of this stockraising strategy we ought to expect not only happier and richer farmers, but better and cheaper food and clothing for all classes of people. The very fact that the business is now on a scientific basis has appealed to students and is attracting men of large abilities who see the opportunity to better rapidly, year by year, the livestock quality of the whole country.

In the field of plant breeding these marvelous results are more rapid and startling because of the wider range of selection. Hybridization, the crossing of different species, has accomplished much more than simple selection. Dr. William Saunders of Canada succeeded in crossing the Ladoga and Fife varieties of wheat and secured a wheat which was earlier than Fife and yielded 
better than Ladoga. Likewise, Luther Burbank was able to produce a hybrid walnut by crossing the English and black walnuts; and Webber and Swingle developed the new fruits called tangerines and citranges by crossing sweet oranges with carefully selected specimens of the wild fruit. Experiments last year in blueberry culture developed luscious berries a half inch in diameter. Possibilities in berry development are almost unlimited, especially by crossing with hardy wild varieties.

Peach raisers have two great obstacles to sure success: drought in the Southwest and frost toward the North. Science is helping them to compete successfully with the severities of Nature. A hardy wild peach has been found in Northern China and grafting on this stock has produced the hardiest peach in Iowa; while another strain bids fair to meet the drought-resisting needs of the Southwest fruit grower.

Our agricultural explorers are searching the world for new varieties which can be used in hybridizing to perfect the American species. For instance, a wild wheat has been found in Palestine which requires very little water. So a specialist in acclimatization was sent directly to the slopes of Mount Hermon to discover its possibilities for American dry farming. If the plant doctors succeed in developing wheat which can be raised in our arid wilderness, it would repay a thousandfold the expense of a round-the-world trip. The possible profits in skillful plant breeding are almost unlimited. Burbank is quoted as asserting: "The right man under favorable conditions can make one dollar yield a million dollars in plant breeding." In 1908 the Min- 
nesota Experiment Station had spent $\$ 40,000$ in breeding the cereal grains. The agricultural department is authority for the opinion that "the increased production is estimated at a thousand-fold, or $\$ 40,000,000$."

The justly famous navel oranges of California can all be traced to two scions sent from the U. S. Department of Agriculture some years ago. The Wealthy apple, which thrives in the cold North better than any other good variety, goes back to the early struggles of Peter Gideon at Lake Minnetonka, who faced the Minnesota winter almost penniless, coatless, and with a family dependent upon him; but had faith enough to invest his hard-earned dollars in selected apple-seed from his far off home in Maine. The largest single contributor to the wealth produced by scientific breeding is said to be the Burbank potato. The vanguard of American experimenters are ranging the world and bring home large-fruited jujubes (as good as dates) from the dry fields of central Asia; scedless Chinese persimmons which have just been successfully fruited in North Carolina; a Japanese salad plant and a vegetable called $u$ do which is similar to asparagus; edible roots called aroids which thrive in swampy land where the potato rots; hardy alfalfa from central Asia successfully crossed with our own varieties for our cold Northwest; drought-resisting cherries, apricots with sweet kernels, Caucasian peaches, olives hardy in zero temperatures, mangoes from Porto Rico, the Paradise apple which grows wild in the Caucasus, the Slew Abrikose, an apricot as smooth as the nectarine, and wild strawberries fruiting in February on the dry cliffs of western Asia which, through cross-breeding, may help 
to carry our native strawberry many miles still farther to the north.

Th. story is endless; but these items suggest to us the thoroughly statesmanlike way in which our agricultural leaders are increasing year by year the possibilities of our soil in spite of all drawbacks of conditions and climate. No wonder they are already prophesying that our annual agricultural production will before long reach twenty billions. When it comes, a large part of the credit must be given to the skillful agricultural scientists who are furnishing all progressive farmers these newer species of plants and animals which are superseding the inferior varieties.

When it is the problem of sterility, it is hopeless. But usually it is merely the problem of aridity; which is only a challenge to entcrprise. Much of our "Great American Desert," as the old geography used to describe it, is in reality the most fertile of all soils; no wonder it can easily be made to "blossom as the rose."

Dr. W. E. Smythe in his fascinating book, "The Conquest of Arid America," calls attention to the fact that the real dividing line between the East and the West is the ninety-serenth meridian which divides in twain the Dakotas, Nebraska, Kansas, Oklahoma, and Texas. East of this line is the region of fairly assured rainfall. To the westward stretches the vast area of arid land with a rainfall insufficient to sustain agriculture, and with only three or four people to the square mile, though with resources enough to support a hundred million people. With a climate matchless for health and a varied and beautiful scenery, coupled with untold mineral deposits and a soil fertility that is remarkable, this 
great section is slowly coming to its own, through the method of irrigation, from the mountains and the streams.

With characteristic Western spirit the same author remarks, "Even in humid regions nothing is so uncertain as the time and amount of the rainfall. In the whole range of modern industry nothing is so crude, uncalculating, and unscientific as the childlike dependence on the mood of the clouds for the moisture essential to the production of the staple necessities of life." The superiority of irrigation as a certain means of water supply which can be regulated at will is a thesis easy to maintain. The results make a marvelous story. "The canal is an insurance policy against loss of crops by drought, while aridity is a substantial guarantee against injury by flood. The rich soils of the arid region produce from four to ten times as largely with irrigation, as the soil of the humid region without it. Twenty acres in the irrigated West should equal 100 acres elsewhere. Certainty, abundance, variety-all this upon an area so small as to be within the control of a single family through its own area, are the elements which compose industrial independence under irrigation."

The small farm unit, usually from five to twenty-five acres, brings neighbors close together, abolishing loneliness and most of the social ills of farm life in the East. Beautiful irrigated villages are springing up which rival in comfort and privilege most places on earth, and combine both city and country privileges, where rural and urban meet. The spirit of coöperation is strong in irrigated communities, enforced by the 
common dependence upon the common enterprise and water supply. This is well illustrated by the Mormon commonwealth, the pioneer irrigators of the West.

The enthusiastic irrigating farmer asserts that irrigation is "the foundation of truly scientific agriculture." "The Western farmer who has learned to irrigate thinks it would be quite as illogical for him to leave the watering of his potato patch to the caprice of the clouds as for the housewife to defer her washday until she could catch rainwater in her tubs." Irrigation certainly furnishes the ideal method of raising a varied crop, giving each crop individual treatment, serving each of thirty varieties of plants and trees with just the amount of daily moisture they individually need, so as to produce maximum products. No wonder three crops in a year sometimes result, and sometimes five crops of alfalfa in the Southwest. Here we come to th: highest development of intensive farming where the utmost value of agricultural science has free play and rivals the results of research and skill in any other line of human effort.

Wonderful as these irrigation projects are, we must not fail to notice that this method of reclaiming arid lands can only be used where there are mountains, rivers, or water courses which can be tapped. Ultimately an area as large as New England and New York State will probably be blessed by irrigation. But this is only a small fraction of the arid West. How shall the rest be reclaimed from the desert? Obviously by some method of dry farming, depending on and conserving the meager rain-fall.

A few simple principles have been discovered, and 
some specialized machinery developed, by which successful dry farming is now conducted on an extensive scale along the arid plains between the Missouri River basin and the Sierra Nevada Mountains. In brief, these principles are: deep plowing, sub-soil packing, intensive cultivation, maintaining a fine dust mulch on the surface, the use of drought-resisting grains, especially certain varieties of wheat, allowing the land to lie fallow every other year to store moisture, and keeping a good per cent. of humus (vegetable matter) in the soil to resist evaporation. In every possible way the dry farmer conserves moisture. The dry mulch is particularly effective. Only a few years ago it was discovered that by capillary attraction much of the water absorbed by the spongy soil during a rain is lost by rapid evaporation, coming to the surface, just as oil runs up a wick. But by stirring the surface the "capillary ducts" are broken up and the moisture tends to stay down in the sub-soil ; for the two inches of dust mulch on the surface acts like a blanket, protecting the precious moisture from the dry winds.

In such brief treatment it is not to be expected that the writer could do justice to the subject of modern agriculture. In fact, there has been little reference to the topic of general farming. In its main outline it is a familiar topic and requires little attention here. The descriptions of certain varieties of specialized agriculture have been given as illustrations of the more remarkable phases of the application of scientific methods to country life. We hope two results have thus been attained, that the dignity and efficiency and scientific possibilities of modern agriculture as a profession have 
been brought to the attention both of our readers in the city and of the discontented farm boys in the country. Both need a higher appreciation of country life.

It should be evident to all that agriculture to-day is thoroughly scientific when rightly practised, which is simply saying that the practice of the new agriculture is a profession. It is among the most difficult and highly technical of all professions. No profession, with the possible exception of medicine, has a broader scientific basis or is at present deriving a greater benefit from vast inductive work in world-wide experimentation at both public and private expense. This profession has made wonderful gains in recent years in both extensive and intensive efficiency, and has written among its triumphs many of the most romantic stories of modern mechanical skill, inventive genius, economic profit, and scientific achievement.

This honorable profession is not only worthy of the finest and ablest of our American young manhood, but its opportunity and present need is a distinct challenge to their attention. Mr. James J. Hill recently stated as his opinion that not more than one per cent. of American farmers in the Middle West were keeping in touch with the agricultural institutions; which is the same as saying they are not keeping up to date. This suggests the need of more intelligent modern farmers tilling the soil as a profession and thus pointing the way to progress for all their neighbors.

This word conservation has but recently won its place of honor in our popular speech; but it is a word of mighty import. The battle for conservation of our 
national resources is on, and it challenges the attention of our young collegians.

It is encouraging to see results already. By a happy combination of progressiveness with true conservatism, we are conserving our national assets from Niagara to the mighty forests of Washington and California and from the arid lands of the mighty empire of Montana to the swamps of Florida. The nation is repenting of its prodigal wastefulness and is now guarding jealously its forest reserves, its vast water-power privileges, its coal and mineral deposits, and its soil fertility, for upon these stores of fundamental wealth depends the prosperity of endless generations. Many alluring chances will come to men now in college to share in this great task of the nation, this fascinating enterprise of conservation.

Any reader must be quite lacking in vision who has been able to read the remarkable progress of modern agricultural science without discerning the deep religious significance of it all. Civilization unquestionably is based on economics. Rural prosperity is a primary condition of rural permanence. Farming must be profitable enough to maintain a self-respecting rural folk; or the open country would be speedily abandoned to a race of peasants and rural heathenism would be imminent.

Progress in agriculture, developing rural prosperity, means the survival of the best rural homes and the finest rural ideals, - otherwise these would go to the city. Retaining in the country a genuine Christian constituency and rural leadership means the survival of the country church. The Christian forces in the country 
have a vast stake in rural prosperity. You cannot hope to build a prosperous country church on poor soil or maintain it on bad farming. This is not a mere matter of scarcity of contributions. It is a result of the poverty of personality among people who are poor Christians because they are poor farmers.

Christian leaders should therefore rejoice in the advance of modern agriculture not only because it all signifies a richer and broader rural prosperity, but also because it makes possible the permanence of rural Christendom and the survival of successful country churches. The more profitable modern farming is made, the richer becomes the opportunity of country life, the larger proportion of the brightest sons and daughters of the farm will resist the lure of the city. Nothing is so vital to the country church, humanly speaking, as to keep in the country parishes a fair share of the country boys and girls of the finest type. With them it lives and serves its community. Without them it will die and its community will become decadent.

It is no selfish Christian spirit that rejoices in the broadening opportunities of country life. The church is but a means to an end. The great objective is the coming of the Kingdom of God for which Jesus prayed. As fast as the very soil of a country is recognized as "holy land," and preserving its fertility is felt to be a patriotic duty; as fast as better live stock, better plant species, and a better breed of men are sought as a working ideal; as fast as the conservation of all natural resources becomes a national life purpose; so rapidly and inevitably the Kingdom of Heaven will come. The Country Life Movement is fundamentally religious. 


\section{XXI \\ ON THE PHYSICAL BASIS OF LIFE \\ Thomas Henry Huxley}

In order to make the title of this discourse generally intelligible, I have translated the term "Protoplasm," which is the scientific name of the substance of which I am about to speak, by the words "the physical basis of life." I suppose that, to many, the idea that there is such a thing as a physical basis, or matter, of life may be novel-so widely spread is the conception of life as a something which works through matter, but is independent of it; and even those who are aware that matter and life are inseparably connected, may not be prepared for the conclusion plainly suggested by the phrase, "the physical basis or matter of life," that there is some one kind of matter which is common to all living beings, and that their endless diversities are bound together by a physical, as well as an ideal, unity. In fact, when first apprehended, such a doctrine as this appears almost shocking to common sense.

What, truly, can seem to be more obviously different from one another, in faculty, in form, and in substance, than the various kinds of living beings? What community of faculty can there be between the brightly colored lichen, which so nearly resembles a mere min- 
eral incrustation of the bare rock on which it grows, and the painter to whom it is instinct with beauty, or the botanist, whom it feeds with knowledge?

Again, think of the microscopic fungus-a mere infinitesimal ovoid particle, which finds space and duration enough to multiply into countless millions in the body of a living $\mathrm{fly}$; and then of the wealth of foliage, the luxuriance of flower and fruit, which lies between this bald sketch of a plant and the giant pine of California, towering to the dimensions of a cathedral spire, or the Indian fig, which covers acres with its profound shadow, and endures while nations and empires come and go around its vast circumference. Or, turning to the other half of the world of life, picture to yourself the great Finner whale, hugest of beasts that live, or have lived, disporting his eighty or ninety feet of bone, muscle, and blubber, with easy roll, among waves in which the stoutest ship that ever left dockyard would flounder hopelessly; and contrast him with the invisible animalcules-mere gelatinous specks, multitudes of which could, in fact, dance upon the point of a needle with the same ease as the angles of the schoolmen could, in imagination. With these images before your minds, you may well ask, what community of forms, or structure, is there between the animalcule and the whale; or between the fungus and the fig-tree? And, a fortiori, between all four?

Finally, if we regard substance, or material composition, what hidden bond can connect the flower which a girl wears in her hair and the blood which courses through her youthful veins; or, what is there in common between the dense and resisting mass of the oak, or the 
strong fabric of the tortoise, and those broad disks of glassy jelly which may be seen pulsating through the? waters of a calm sea, but which drain away to mere films in the hand which raises them out of their element?

Such objections as these must, I think, arise in the mind of every one who ponders, for the first time, upon the conception of a single physical basis of life underlying all the diversities of vital existence; but I propose to demonstrate to you that, notwithstanding these apparent difficulties, a threefold unity-namely, a unity of power or faculty, a unity of form, and a unity of substantial composition-does provide the whole living world.

No very abstruse argumentation is needed, in the first place, to prove that the powers, or faculties, of all kinds of living matter, diverse as they may be in degree, are substantially similar in kind.

Goethe has condensed a survey of all powers of mankind into the well-known epigram:

Warum treibt sich das Volk so und schreit? Es will sich ernähren. Kinder zeugen und die nähren, so gut es vermag.

Weiter bringt es kein Mensch, stell' er sich, wie er auch will.*

In physiological language this means, that all the multifarious and complicated activities of man are comprehensible under three categories. Either they are immediately directed toward the maintenance and development of the body, or they effect transitory changes in the relative positions of parts of the body, or they tend toward the continuance of the species. Even those

\footnotetext{
* Why do people struggle so and clamor? They wish to maintain themselves, to bring forth children, and nourish them as well as they can. . . Further than this no man attains, strive how he may.
} 
manifestations of intellect, of feeling, and of will, which we rightly name the higher faculties, are not excluded from this classification, inasmuch as to every one but the subject of them, they are known only as transitory changes in the relative positions of parts of the body. Speech, gesture, and every other form of human action are, in the long run, resolvable into muscular contraction, and muscular contraction is but a transitory change in the relative positions of the parts of a muscle. But the scheme which is large enough to embrace the activities of the highest form of life, covers all those of the lower creatures. The lowest plant, or animalcule, feeds, grows, and reproduces its kind. In addition, all animals manifest those transitory changes of form which we class under irritability and contractility; and, it is more than probable, that when the regetable world is thoroughly explored, we shall find all plants in possession of the same powers, at one time or other of their existence.

I am not now alluding to such phenomena, at once rare and conspicuous, as those exhibited by the leaflets of the sensitive plants, or the stamens of the barberry, but to much more widely spread, and, at the same time, more subtle and hidden, manifestations of vegetable contractility. You are doubtless aware that the common nettle owes its stinging property to the innumerable stiff and needlelike, though exquisitely delicate, hairs which cover its surface. Each stinging-needle tapers from a broad base to a slender summit, which, though rounded at the end, is of such microscopic fineness that it readily penetrates, and breaks off in the skin. The whole hair consists of a very delicate outer 
case of wood, closely applied to the inner surface of which is a layer of semi-fluid matter, full of innumerable granules of extreme minuteness. This semi-fluid lining is protoplasm, which thus constitutes a kind of bag, full of limpid liquid, and roughly corresponding in form with the interior of the hair which it fills. When viewed with a sufficiently high magnifying power, the protoplasmic layer of the nettle hair is seen to be in a condition of unceasing activity. Local contractions of the whole thickness of its substance pass slowly and gradually from point to point, and give rise to the appearance of progressive waves, just as the bending of successive stalks of corn by a breeze produces the apparent billows of a cornfield.

But in addition to these movements, and independently of them, the granules are driven, in relatively rapid streams, through channels in the protoplasm which seems to have a considerable amount of persistence. Most commonly, the currents in adjacent parts of the protoplasm take similar directions; and, thus, there is a general stream up one side of the hair and down the other. But this does not prevent the existence of partial currents which take different routes; and sometimes trains of granules may be seen coursing swiftly in opposite directions within a twenty-thousandth of an inch of one another; while, occasionally, opposite streams come into direct collision, and after a longer or shorter struggle, one predominates. The cause of these currents seems to lie in contractions of the protoplasm which bounds the channels in which they flow, but which are so minute that the best microscopes show only their effect, and not themselves. 
The spectacle afforded by the wonderful energies prisoned within the compass of the microscopic hair of a plant, which we commonly regard as a merely passive organism, is not easily forgotten by one who has watched its display, continued hour after hour, without pause or sign of weakening. The possible complexity of many other organic forms, seemingly as simple as the protoplasm of the nettle, dawns upon one; and the comparison of such a protoplasm to a body with an internal circulation, which has been put forward by an eminent physiologist, loses much of its startling character. Currents similar to those of the hairs of the nettle have been observed in a great multitude of very different plants, and weighty authorities have suggested that they probably occur, in more or less perfection, in all young vegetable cells. If such be the case, the wonderful noon-day silence of a tropical forest is, after all, due only to the dulness of our hearing; and could our ears catch the murmurs of these tiny Maclstroms, as they whirl in the innumerable myriads of living cells which constitute each tree, we should be stunned, as with the roar of a great city.

Among the lower plants, it is the rule rather thas the exception, that contractility should be still more openly manifested at some periods of their existence. The protoplasm of Algre and Fungi becomes, under many circumstances, partially, or completely, freed from its woody case, and exhibits movements of its whole mass, or is propelled by the contractility of one, or more, hair-like prolongations of its body, which are called vibratile cilia. And, so far as the conditions of the manifestations of the phenomena of contractility have 
yet been studied, they are the same for the plant as for the animal. Heat and electric shocks influence both, and in the same way, though it may be in different degrees. It is by no means my intention to suggest that there is no difference in faculty between the lowest plant and the highest, or between plants and animals. But the difference between the powers of the lowest plant, or animal, and those of the highest, is one of degree, not of kind, and depends, as Milne-Edwards long ago so well pointed out, upon the extent to which the principles of the division of labor is carried out in the living economy. In the lowest organism all parts are competent to perform all functions, and one and the same portion of protoplasm may successfully take on the function of feeding, moving, or reproducing apparatus. In the highest, on the contrary, a great number of parts combine to perform each function, each part doing its allotted share of the work with greater accuracy and efficiency, but being useless for any other purpose.

On the other hand, notwithstanding all the fundamental resemblances which exist between the powers of the protoplasm in plants and in animals, they present a striking difference (to which I shall advert more at length presently), in the fact that plants can manufacture fresh protoplasm out of mineral compounds, whereas animals are obliged to procure it ready-made, and hence, in the long run, depend upon plants. Upon what condition this difference in the powers of the two great divisions of the world of life depends, nothing is at present known.

With such qualifications as arise out of the last- 
mentioned fact, it may be truly said that the acts of all living things are fundamentally one. Is any such unity predicable of their forms? Let us seek in easily verified facts for a reply to this question. If a drop of blood be drawn by pricking one's finger, and viewed with proper precautions, and under a sufficiently high microscopic power, there will be seen, among the innumerable multitude of little, circular, discoidal bodies, or corpuscles, which float in it and give it color, a comparatively small number of colorless corpuscles, of somewhat larger size and very irregular shape. If the drop of blood be kept at the temperature of the body these colorless corpuscles will be seen to exhibit a marvelous activity, changing their forms with great rapidity, drawing in and thrusting eut prolongations of their substance, and creeping about as if they were independent organisms.

The substance which is thus active is a mass of protoplasm, and its activity differs in detail, rather than in principle, from that of the protoplasm of the nettle. Under sundry circumstances the corpuscle dies and becomes distended into a round mass, in the midst of which is seen a smaller spherical body, which existed, but was more or less hidden, in the living corpuscle, and is called its nucleus. Corpuscles of essentially similar structure are to be found in the skin, in the lining of the mouth, and scattered through the whole framework of the body.

Nay, more; in the earliest condition of the human organism, in that state in which it has but just become distinguishable from the egg in which it arises, it is nothing but an aggregation of such corpuscles, and 
every organ of the body was, once, no more than such an aggregation.

Thus a nucleated mass of protoplasm turns out to be what may be termed the structural unit of the human body. As a matter of fact, the body, in its earliest state, is a mere multiple of such units; and in its perfect condition, it is a multiple of such units variously modified.

But does the formula which expresses the essential structural character of the highest animal cover all the rest, as the statement of its powers and faculties covered all the others? Very nearly. Beast and fowl, reptile and fish, mollusk, worm, and polype, are all composed of structural units of the same character, namely, masses of protoplasm with a nucleus. There are sundry very low animals, each of which, structurally, is a mere colorless blood-corpuscle, leading an independent life. But, at the very bottom of the animal scale, even this simplicity becomes simplified, and all the phenomena of life are manifested by a particle of protoplasm without a nucleus. Nor are such organisms insignificant by reason of their want of complexity. It is a fair question whether the protoplasm of those simplest forms of life, which people an immense extent of the bottom of the sea, would not outweigh that of all the higher living beings, which inhabit the land put together. And in ancient times, no less than at the present day, such living beings as these have been the greatest of rock builders.

What has been said of the animal world is no less true of plants. Embedded in the protoplasm at the broad, or attached, end of the nettle hair, there lies a 
spheroidal nucleus. Careful examination further proves that the whole substance of the nettle is made up of a repetition of such masses of nucleated protoplasm, each contained in a wooden case, which is modified in form, sometimes into a woody fibre, sometimes into a duct or spiral vessel, sometimes into a pollen grain, or an ovule. Traced back to its earliest state, the nettle arises as the man does, in a particle of nucleated protoplasm. And in the lowest plants, as in the lowest animals, a single mass of such protoplasm may constitute the whole plant, or the protoplasm may exist without a nucleus.

Under these circumstances it may well be asked, how is one mass of non-nucleated protoplasm to be distinguished from another? Why call one "plant" and the other "animal"?

The only reply is that, so far as form is concerned, plants and animals are not separable, and that, in many cases, it is a mere matter of convention whether we call a given organism an animal or a plant. There is a living body called Ethalium septicum, which appears upon decaying vegetable substances, and in one of its forms is common upon the surfaces of tan-pits. In this condition it is, to all intents and purposes, a fungus, and formerly was always regarded as such; but the remarkable investigations of De Bary have shown that, in another condition, the Ethalium is an actively locomotive creature, and takes in solid matters, upon which apparently, it feeds, thus exhibiting the most characteristic feature of animality. Is this a plant; or is it an animal? Is it both; or is it neither? Some decide in favor of the last supposition, and establish an intermediate kingdom, a sort of biological No Man's Land 
for all these questionable forms. But, as it is admittedly impossible to draw any distinct boundary line between this no man's land and the vegetable world on the one hand, or the animal, on the other, it appears to me that this proceeding merely doubles the difficulty which, before, was single.

Protoplasm, simple or nucleated, is the formal basis of all life. It is the clay of the potter: which, bake it and paint it as he will, remains clay, separated by artifice, and not by nature, from the commonest brick or sun-dried clod.

Thus it becomes clear that all living powers are cognate, and that all living forms are fundamentally of one character. The researches of the chemist have revealed a no less striking uniformity of material composition in living matter.

In perfect strictness, it is true that chemical investigation can tell us little or nothing, directly, of the composition of living matter, inasmuch as such matter must needs die in the act of analysis,-and upon this very obvious ground, objections, which I confess seem to me to be somewhat frivolous, have been raised to the drawing of any conclusions whatever respecting the composition of actually living matter, from that of the dead matter of life, which alone is accessible to us. But objectors of this class do not seem to reflect that it is also, in strictness, true that we know nothing about the composition of any body whatever, as it is. The statement that a crystal of calc-spar consists of carbonate of lime is quite true, if we only mean that, by appropriate processes, it may be resolved into carbonic acid and quicklime. If you pass the same carbonic acid over the 
very quicklime thus obtained, you will obtain carbonate of lime again; but it will not be calc-spar, nor anything like it. Can it, therefore, be said that chemical analysis teaches nothing about the chemical composition of calcspar? Such a statement would be absurd; but it is hardly more so than the talk one occasionally hears about the uselessness of applying the results of chemical analysis to the living bodies which have yielded them.

One fact, at any rate, is out of reach of such refinements, and this is, that all the forms of protoplasm which have yet been examined contain the four elements, carbon, hydrogen, oxygen, and nitrogen, in very complex union, and that they behave similarly toward several reagents. To this complex combination, the nature of which has never been determined with exactness, the name of protein has been applied. And if we use this term with such caution as may properly arise out of our comparative ignorance of the things for which it stands, it may be truly said that all protoplasm is proteinaceous, or, as the white, or albumen, of an egg is one of the commonest examples of a nearly pure protein matter, we may say that all living matter is more or less albuminoid.

Perhaps it would not yet be safe to say that all forms of protoplasm are affected by the direct action of electric shocks; and yet the number of cases in which the contraction of protoplasm is shown to be affected $t$ this agency increases every day.

Nor can it be affirmed with perfect confidence that all forms of protoplasm are liable to undergo that peculiar coagulation at a temperature of $49^{\circ}-50^{\circ}$ centigrade, which has been called "heat-stiffening," though Kühne's 
beautiful researches have proved this occurrence to take place in so many and such diverse living beings, that it is hardly rash to expect that the law holds good for all.

Enough has perhaps been said to prove the existence of a general uniformity in the character of the protoplasm, or physical basis of life, in whatever group of living beings it may be studied. But it will be understood that this general uniformity by no means excludes any amount of special modifications of the fundamental substance. The mineral, carbonate of lime, assumes an immense diversity of characters, though no one doubts that, under all the Protean changes, it is one and the same thing. 


\section{XXII \\ NEW PLANT IMMIGRANTS *}

David Fatrchild

To readers of the National Geographic Magazine who have wandered with men of many tastes all over the world, the thought must of ten have come, "Of what use are all the strange plants which make up the landscapes of the pictures?" The globe, with its kaleidoscopic panorama of people, animals, and plants, has been whirled before you, as it were, and you have in your minds the picture of a ball circling through space, covered with a film of plants, animals, and men in constant change. So varied is this film of plants that there are probably half a million distinct, specific forms in it, and yet man uses only a few hundred for his own purposes.

To change, in a measure, the distribution of the really useful plants of the world is what the office of Foreign Seed and Plant Introduction of the Department of Agriculture is trying to do. The motive underlying this work might be called the ambition to make the world more habitable. If one is inclined to be pessimistic with regard to the food supply of the world, he has only to talk to any one of the enthusiasts of the Department of Agriculture to get a picture of the widening vista of agricultural possibilities which would

* From the National Geographic Magazine. Copyright, 1911. By permission of the author and the publishers. 
make him realize that the food problems of the race are not hung in the balance of our Great Plains area, and that the food-producing power of the world is still practically unknown, because we have just begun to study, in a modern way, the relative performance of different plants.

We may not always grow the plants we do now. Some of them are expensive food producers, some produce foods that are difficult to digest, and some we may leave behind as we learn to like others better.

What to grow was not so serious a question to the early Phœnician peasant, who knew perhaps a dozen crops, as it is becoming to the American agriculturist, who can pick from the crops of all the world the one best suited to his land and climate. Changes come so rapidly nowadays that if a man to-day talks of "pears" he may mean what are ordinarily thought of as pears, or he may refer to alligator pears, which he is growing in Florida, or prickly pears which he is cultivating in Texas. Both the alligator pear and the prickly pear have come in as crops to be reckoned with within the past fifteen years, and already the stockraisers of the South are wondering if they should plan spiny or spineless forms of the prickly pear cactus, and the fruitgrowers of Florida are inquiring as to which of the several varieties of alligator pear tree is going to be the most productive and profitable.

To help find the plant which will produce the best results of any that can be grown, on every acre of land in the United States, is, in general, the broad policy of the office of Seed and Plant Introduction of the Bureau of Plant Industry. 
Although begun in a systematic way and as a distinct activity of the Department in 1897 , it has barely touched the fringe of its possibilities. The 31,000 different plant immigrants which have come in, and have cither died or are now growing somewhere in this country, represent a small beginning only, and have merely helped to show the greatness of the possibilities which progress in agricultural research is creating.

"You will soon have all the crops in," is the remark of those who have given the matter little thought. Our own lives change with every moment of time, and so do the lives of plants. The strains of potato which our grandfathers grew are, with few exceptions, different from the strains in rogue to-day; and, fitting their lives into the various conditions of soil and climate, the original wild South American species of potato, Solanum tuberosum, assumes in the hands of men a thousand different forms.

In whatever parts of the world new forms may spring into existence it matters not; our potato-growers should be able to try every sport of importance and every wild, hardy species, whether it comes from the manse of a Scottish parson, is discovered as a wild species along the Paraguay River by an American railway bridge-builder, is found among the mountains of Columbia by a Jesuit priest, is gathered by a forest ranger in the dry regions of an Indian reservation in New Mexico, or is secured by a trained collector from the Chiloe Islands off the coast of Chile. It makes little difference; they must all come in as plant immigrants to show what they can do in the gardens of American experts. There is always the chance that they may be 
thrown out as unprofitable; but, if they have desirable characters, they can be blended with others, or exploited with others, if they are superior for any of the potato regions of this country.

It may be new to many that every day plant immigrants from different parts of the world arrive in Washington, and every day, through the mails, hundreds of these disinfected arrivals go out to find a new home in some part of the country.

It is a difficult matter to give an adequate impression of the magnitude and importance to the country of this stream of new plant immigrants which for fourteen years has been pouring into the country, and has been directed by a great and growing body of research men and women into those regions where it was thought they might make their homes.

In the brief space of a short article, and to avoid what would be almost a bare enumeration of plant names, I prefer to treat of only a few of the many important problems with which the office is working, passing by, also, the introduction of the Durum wheat, the Japanese rice, and giving the Siberian alfalfas, which are earning for the farmers of the country many millions of dollars a year, a bare mention, for the reason that they have been so often described in the magazines and daily papers.

The mango is one of the really great fruits of the world. India, with its hundreds of millions of people, has for centuries held it sacred, and celebrates annual ceremonies in its honor. The great Mogul Akbar, who reigned in the sixteenth century, planted the famous Lak Bag, an orchard of a hundred thousand mangos, 
and some of these still remain alive. It is a fruit the importance of which Americans are at last beginning to recognize, notwithstanding the unfortunate discredit which the worthless seedling mangos of the West Indies have given it in the minds of Americans generally.

There are probably more varieties of mangos than there are of peaches. I have heard of one collection of five hundred different sorts in India. There are exquisitely flavored varieties no larger than a plum, and there are delicious sorts the fruits of which are six pounds in weight. In India, where the wage of a coolie is not over ten cents a day, there are varieties which sell for $\$ 6.60$ a hundred, and the commonest sorts bring over a cent apiece.

The great mango trees of India are said to reach a height of seventy feet, and are so loaded down with fruit that over $\$ 150$ worth has been sold from a single tree. These fine varieties, practically as free from fiber as a freestone peach, can be eaten with a spoon as easily as a cantaloupe. Trainloads of these are shipped from the mango-growing centers of India and distributed in the densely peopled cities of that great semi-tropical empire; and yet, notwithstanding the great importance of this fruit, the agricultural study of it from the new standpoint has scarcely been begun. I believe that it has never, for example, been tested on any but its own roots.

We have gathered together in Florida and Porto Rico and Hawaii more than a hundred varieties, and some which we have fruited have already attracted the attention of the fancy fruit dealers, who agree that the demand for these will increase as fast as the supply can 
be created and maintain that extravagant prices, such as fifty or even seventy-five cents apiece, will be paid for the large, showy, delicious fruits. Last year three hundred dozen Mulgoba mangos were sold in Florida, for three dollars a dozen. The Governor of Porto Rico has committed himself to a policy which, if carried out, will cover the island with hundreds of thousands of mango trees of the better varieties.

One of the oldest cultivated plants in the world is the date palm. At least four thousand years ago it was growing on the banks of the Euphrates, and it is this plant and the camel that together made it possible for the Arabs to populate the great deserts of northern Africa and Asia. The date palms would grow where the water was alkaline, and the camels were able to make long journeys across the desert to take the dates to the coast to market and sell them for wheat and olives.

In these deserts of the old world, millions of Arabs live on dates, for the date palm can be cultivated on land so salty as to prevent the culture of any other paying crop, and it will live in the hottest regions on the face of the globe; not even a temperature of 125 degrees Fahrenheit will affect it. This obliging plant does not, however, insist on such temperatures, but will stand some frost, and has been known to live where the mercury falls to 12 degrees Fahrenheit.

It is also the only wood obtainable in the oases of the Sahara, and on the shores of Arabia boats are made of it.

The date palm has both male and female flowers and they occur on separate plants, and the Arabs have to 
plant one male for every plantation of a hundred females, making a harem as it were. The artificial pollination or fertilization of the female palms is one of the most interesting processes practised with plantis, a spray of flowers from a male palm being bound with a bit of palm-leat fiber in each inflorescence of the female tree. Propagation of the date palm can be accomplished by means of seeds, or suckers, which are thrown up at the base of the palm. Suckers will start, however, on land so salty that the seeds refused to grow on it.

Four years from seed, trees of some varieties begin to bear and in six years will have paying crops of dates. They live to a much greater age than almost any other of the fruit trees, and specimens a century old are said to be still a good investment.

The date is not a dry-land crop, but requires irrigation to grow and produce fruit. A plantation once established requires to be kept free of weeds, to bc pollinated when the palms come into bloom, and to have the fruit harvested when ripe. Of insect pests we know too little as yet, though the prospective planter should count this in his estimate of expense; remembering, however, that modern scientific methods have overcome the greatest fruit pests, and that these on the palm are not different in general character from those which are now under complete control.

Very little pruning of the palms is necessary, and the harvesting is very simple, since the dates grow in great bunches, which often weigh from twenty to forty pound: apiece.

There are over a hundred varieties of dates no: 
growing in the government gardens in California and Arizona, from which are being distributed to prospective planters the suckers as they grow. This accomplishment of the Department of Agriculture is not the result of any one man's effort, but the product of at least a dozen minds working over a period of twenty years and in seven different countries. And the names of these investigators deserve to be here chronicled before their part of this unusual work is forgotten, as the industry which is now growing rapidly brings new personalities into the field. Water T. Swingle, to whom is due the credit for the most profound work which has been done; H. E. Van Demen, J. W. Toumey, R. H. Forbes, T. H. Kearney, P. H. Dorsett, A. V. Stubenrauch, S. C. Mason, A. J. Pieters, Bruce Drummond, Consul Haggleson, E. A. Bessey, Dr. Vinson, Bernard Johnson, and David Fairchild are the names of those who took the most active part in this problem, while the name of Mr. Barbour Lathrop, of Chicago, should be specially mentioned, since it was through his generosity that the writer was able to make a study of the Persian and Arabian date regions.

There are among these hundred varieties those which candy on the tree, others which are used mainly for cooking, and some which are hard and not sticky. There are early varieties and late-ripening ones, varieties short and long, and every sort can be told by the grooves on its seeds.

One of the finest varieties is the Deglet Noor, which will bear from 80 to 132 pounds of dates per tree. As the dates sell from 8 to $\mathbf{3 5}$ and even 50 cents a pound, the possibilities of a profit of at least $\$ 150$ an acre 
has been set as the probable mean on well-managed plantations.

The date as a delicacy is known to every American child, but, as a food, remains to be discovered by the American public. When the date plantations of Arizona and California come into full bearing, as they should in about ten years, the hard, dry dates, for example, now quite unknown on our markets, are sure to come into prominence and find their way to the tables of the poor as well as of the rich. The heat of our American summers is forcing us to study the hot weather diets of other countries, and dates are sure to become important items of food.

The persimmon of the South, on which the opossum fattens, is a very different fruit from its relative the kaki, or persimmon of the Orient, the growing of which is so great an industry in Japan as to nearly equal the Japanese orange-growing industry in importance. Our persimmon is a wild fruit, which will some day be domesticated, while the kaki has been cultivated so long that it is represented by hundreds of distinct varieties of different forms and colors. It is true that the Oriental persimmon has been grown in this country; in fact, the census records a production of 68 tons; but this is scarcely a beginning as compared with the 194,000 tons which is the output of Japan.

We have misunderstood the persimmon. Our own wild ones we can eat only after they have been touched by the frost, and the imported Japanese ones we have left until they become soft and mushy and almost on the verge of decay. We never thought until quite recently of wondering whether in a land where the persimmon 
had been cultivated for centuries they would not have worked out some artificial method of removing the objectionable pucker. In Japan we find this is done by packing the fruit in barrels saturated with sake, and Mr. H. C. Gore, of the Department of Agriculture, is now working out new methods of processing the Oriental persimmon, so that it can be eaten when hard as an apple, and there will no longer be any reason why it should not take its place among the great fruits of the country.

We have also introduced a Chinese persimmon which Mr. Frank Meyer found in the Ming Tombs Valley, the 'Tamopan, four inches in diameter, and seedless and puckerless.

The whole question of the improvement of the persimmon has been opened up and we are getting for this work the small-fruited species called "lotus," from Algeria; a tropical species with whitc, chense-like pulp, from Manila, Mexico, Erithea, and Rhodesia; species from Bangalore, from Sydncy, from Madras, from the Mankau Pass, in China, and from the Caucasus.

There are large areas of the West where the native persimmon is the slowest tree to wake up in the warm spells that visit that region in February. It is reported that in Oklahoma last February the temperature went up to $\mathbf{8 0}$ degrees Fahrenheit, which is as high as the average midsummer temperature. This will wake up almost any tree or plant except the persimmon, and when a temperature of 17 degrees below zero follows, it kills thousands of plants to the ground. If the fine imported varieties can by breeding be made to share this characteristic with their American relatives, it 
will be an added reason for their extensive cultivation.

If the Oriental timber bamboo had produced seeds oftener than once in forty years it would long ago have been introduced and be now growing in the South. The fact that it had to be brought over in the form of living plants, and that these plants required special treatment, has stood in the way of the quick distribution of this most important plant throughout those portions of America where it will grow. After several unsuccessful attempts, a beginning has at last been made, and the Department has a grove of Oriental bamboos in northern Florida, and a search is being made in different parts of the world for all those species which are adapted to our climate.

It was while I was traveling in Japan for Mr. Barbour Lathrop, of Chicago, that he called my attention to the great importance of the bambon as a new crop for the South. He was so firmly convinced of its importance that he offered to purchase and send as a gift to the country two thousand plants for trial. Unfortunately, the offer was not accepted, and it was not until several years later that the large shipment was made which is now establishing itself in northern Florida, where the first commercial grove of these remarkable plants is to find its home.

"Of what practical use is the bamboo?" is the question of the Occidental, and it must seem to the Oriental as singular as his question would be, "Of what use is the white pine to the American?" For there is no plant in the world which is put to so many uses as the bamboo, and in the regions where it grows it is apparently the most indispensable of all plants. 
In this country I predict it will be used earliest for barrel hoops, for cheap irrigating pipes, for vine-stakes and trellises, for light ladders and stays for overloaded fruit trees, for baskets and light-fruit shipping crates, and for food. As wind-breaks and to hold canal banks and prevent the erosion of steep hillsides, there are species which excel all other plants, while for light furniture and jalousies it is sure to find a market whenever the green timber is available.

Unlike the forest trees, the giant bamboos are trut grasses. They send underground stems long distances through the soil, binding it together with hard, flintlike rhizomes. They send up from this network of roots and rhizomes the most rapid-growing shoots of any plants known; and, like giant asparagus stems, these shoot at the rate of a foot a day into the air. So fresh and tender are these shoots that they can be snanped off with the hand, and when cooked they form one of the great vegetable delicacies of the world.

No wonder, then, considering all the uses of this plant, that the Chief Forester of Iapan, when I asked him about the value of the bamboo industry in his country, said at once: "It's the best-paying plant industry in Japan." I am aware that there enters in here that complicated question of the cheapness of Oriental labor, and that there are many things which we cannot do with the bamboo which are done in Japan and China. But all these things aside, the bamboo still remains one of the most promising plant introductions.

While perhaps the great majority of these new plants are brought in or purchased directly as results of investigations carried on in Washington, some of the 
most valuable things have been sent in by men and women living as missionaries or voluntary exiles in the most out-of-the-way places in the world.

Plant introduction is not a matter of one generation, and it is most preëminently a work requiring many men working together, and I doubt if there is to be found within the government service, or outside of it, a better example of coöperative, constructive investigation than that connected with the Bureau of Plant Industry in the establishment of new plant industries in the United States.

On the streets of almost any Japanese city the fruit and vegetable stalls have for sale an attractive blanched vegetable called udo. It is a near relative of a wellknown wild plant in New England, the spikenard, but a much larger plant. There are many ways in which it is prepared by both the Japanese and the foreigners who live in Japan; but, either as a salad or cooked in the same way in which asparagus is cooked, it deserves to rank as one of the important vegetables of the world. It is easy to grow; it does not require replanting oftener than once in nine or ten years; it can be cropped in the autumn or in the spring, and it yields large crops of shoots, which are often two feet long and an inch or more in diameter at the base. These brilliant white shoots are edible to their very bases without the least objectionable fiber, and not in this respect like asparagus, of which only the tips are fit to eat.

It was while traveling with Mr. Barbour Lathrop that the writer first made the acquaintance of this vegetable and at his suggestion that plants of it were sent to America, in 1902. 
One of our best-known botanical authorities once remarked to me: "You cannot introduce a new vegetable; it's impossible." While it might be admitted that the introduction of a new vegetable is a long undertaking, extending perhaps over the period of a generation, it should not be left out of account that the means at our disposal to-day are immeasurably more powerful than they were even two decades ago. The advent of the great hotels and the sympathetic interest of the great magazines are two elements which to-day make possible what yesterday would have been quite impossible.

The magazines will talk about a new vegetable and can now illustrate it as never before and in this way encourage people to ask for it, and the great hotels have learned to profit by the introduction of novelties.

Of course, from the narrow standpoint of the asparagus grower we should all eat asparagus, and he watches every sign that indicates any tendency on the part of the public to consume more of his vegetable, and he is not often likely to look with favor on any rival. But let fancy prices be established by a legitimate publicity and the encouragement of some of the large hotels, and the growers of asparagus will soon find out that there is money in growing the new vegetable. We can trust to a final readjustment of things, once the new plant is thoroughly established.

It was with this point in view that an arrangement was made with the National Geographic Society, at its last Annual Banquet, to serve as one of the courses the dasheen, which is the root of a large-leaved plant related to the Hawaiian taro. The guests of the Society 
were kind enough to pass judgment on this new introduction, deciding it to be a valuable addition to the menu, many even going so far as to declare that it surpassed the potato in excellence.

The stimulus given to the cultivation of this dasheen by this exhibition has been very great and to-day thousands have heard of it, and, if they saw it offered on the menu of a first-class hotel, would be much more likely to call for it than if they had never read of its peculiar adaptability to the moist but well-drained lands of the Southern States. 


\section{XXIII}

\section{BACTERIA AND SOIL FERTILITY*}

\section{P. E. Brown}

THE problem of obtaining maximum crops is centuries old but the agricultural world is still awaiting its solution.

It is known now that the crop any soil will yield under particular climatic conditions depends on the character and condition of the soil. If the soil is poor and infertile, the crop may be expected to be small; if it is rich and climatic conditions are favorable, the yields should be large. The real problem, then, is how to make the soil fertile and how to keep it so. If it is poor, then improvement is necessary; if it is good, further inprovement may pay. There are probably few soils so poor that proper methods cannot put them on a paying basis; on the other hand, there are no soils so rich that they will always continue to be fertile.

Therefore, a study of soil fertility, or the crop producing power of a soil under given climatic conditions, is of vast importance. Men must have knowledge of the fertility of a soil if they would properly regulate its support power so that the needed supply of plant food may be available for crop production.

Plant food consists of those chemical elements which

* From Bacteria and Soil Fertility, by permission of the Iow A Agricultural Experiment Station, Iowa State College. 
are essential for the growth of plants and includes a large number of substances. Among these, nitrogen, potassium, phosphorus, and sulphur are most likely to be lacking in soils. In rare cases other elements may be deficient, but in normal soils, if enough of these four elements is present in a soluble, available form, the support power of the soil is satisfactory.

Many soils contain enough of these four necessary elements but they are locked up in an insoluble and unavailable form and hence must be changed and made soluble to be of use to crops. How is this change accomplished? What determines the production of soluble plant food in the soil? What regulates the support power of the soil? These are the questions that require a definite answer.

The factors which bring about the change of insoluble substances into soluble in the soil may be grouped into three classes, physical, chemical, and bacteriological.

The physical factors, such as light, heat, water, air, etc., and the chemical factors, such as soil acidity or sourness, the character of the chemical compounds present, etc., have been known and studied for many years. The bacteriological factors have come into prominence only quite recently, but now they are recognized to be of as much, if not more importance than the other two groups.

It has been well said that these three groups of factors working together constitute the "commissary dopartment for the army of plant life."

While, therefore, it is quite generally known now that the soil is the home of myriads of microscopic 
plants called bacteria, and that these have much to do with fertility, there is still a great deal of haziness about the subject in the public mind.

Before considering the part which bacteria take in liberating plant food it is well to bear in mind the fundamental facts about bacteria.

-Bacteria are minute plants, consisting of single cells. These cells are made up of a cell-w. ll, and the living substance or protoplasm within the cell-wall. In the protoplasm the life processes are carried on. When food is absorbed, it passes into the cell through the cellwall and the necessary portions are taken up by the protoplasm while the waste is eliminated, passing out through the cell-wall.

There are three main types of bacteria grouped according to form. They are the cocci or spheres, the bacilli or rods, and the spirilla or spirals. These groups have been popularly described as billiard balls, lead pencils, and corkscrews. By far the largest number of soil bacteria belong to the group of bacilli or rods.

These simple organisms multiply by fission, that is, one cell divides into two equal parts, which may separate or may remain united. The spherical bacteria, due to their method of multiplication, frequently appear as packets of varying numbers of organisms, while the rods and spirals appear singly or in chains.

The splitting of one organism into two may be completed in twenty minutes to one half hour under very favorable conditions. At this rate, in one day one organism would become about $300,000,000,000,000$. As a matter of fact, however, such a rapid multiplication cannot occur, as food conditions do not remain 
satisfactory and the growth of the organism gives products that restrict development.

Bacteria are very small, ranging from $1-50,000$ to 1-1,000 of an inch in length and averaging about 1-25,000 of an inch.

Many bacteria have flagella, or long thread-like appendages, by means of which they move about freely in any liquid in which they may be growing. These flagella may be attached in various ways, singly at the end of the organism, in tufts of several at one or both ends, or scattered indiscriminately over the organism.

Some bacteria, under certain conditions, produce socalled spores, or cells surrounded by a very resistant cell-wall. They will remain alive practically indefinitely if not exposed to extremes of heat or cold and if kept dry; and when placed under favorable conditions will germinate and produce active bacteria again.

All bacteria may be included in one of two large classes depending on their functions, or the character of their activities. These are parasites and the saprophytes. The parasites include all the disease producers. The saprophytes are the decay producers. Many people think of all bacteria as connected with disease. They know that typhoid, diphtheria, tuberculosis, and other discases are caused by bacteria and fall into the error of believing that all organisms are active in causing some dread disease. Such is far from being the case, however. The saprophytic, or decay bacteria, are invaluable. They have been called the "link between the world of the living and the deau." They transform dead materials back into living matter and thus complete the cycles through which, in nature, 
all substances must go. Bacteria are everywhere, in the air, the water, the soil, but contrary to the common belief, which is that we are becoming "bacteria crazy," such general distribution is no cause for alarm but rather a source of benefit. A bacteria-free world would soon be a dead world.

Enormous numbers of bacteria inhabit the soil, some of them harmful, but the vast majority beneficial. Actual counts have shown that the numbers present in the soils may vary from a few thousand per gram to over fifty million per gram.

There are certain conditions affecting their growth. In other words, the bacteria in the soil, just as in any other environment, are greatly influenced by certain physical and chemical conditions. These conditions are moisture, temperature, acration, reaction, and food supply.

A proper amount of water in the soil is as necessary for the growth of bacteria as for crops. Either excessive moisture or severe drought interferes with bacterial growth very considerably. Many organisms are killed by too much moisture, many others, by insufficient moisture. Merely drying out a soil by exposing it to the air, however, will not kill the bacteria present. Such soils, kept for years in an air-dry state, have been shown to contain certain bacteria which had evidently been in a dormant state or condition. Such farm practices as drainage, which removes excessive water, or cultivation, which prevents undue loss of water by evaporation, have an important influence on the bacteria in the soil. Recent work has shown that small variations in moisture are of little influence on bacteria in the field, 
other factors apparently being of greater importance, but when variations are large, then moisture becomes the governing factor.

Every organism grows the best in a certain temperature. Each also has so-called maximum and minimum temperatures at which point growth ceases. The best temperature for most soil organisms ranges from $65^{\circ}$ to $90^{\circ} \mathrm{F}$., although of course there are exceptions to this statement. Most organisms are not killed by excessive cold but merely remain dormant. In fact, it has been shown recently that certain bacteria are alive and active in soil in late winter, at a soil temperature somewhat below the freezing point. It is generally considered, however, and with reason, that the greatest bacterial activities occur in the soil during the summer and are then of the most significance.

Depending upon their requirements as to air, bacteria may be divided into three classes: those which require air for their growth; those which grow only in the absence of air; and those which prefer air but will grow without it. In general it may be said that the beneficial bacteria in the soil need air. Hence in heavy clay soils where there is not enough air, methods which increase the circulation of oxygen in the soil increase bacterial activities; these increase the solution of plant food and this ultimately increases plant production. On the other hand, if there is too much air present, as in light sandy soils, the bacterial activities will be too great and the humus will be burned up too rapidly, plant food will be produced in too large quantities to be utilized by the crops, and more or less extensive losses of valuable soil elements will occur. Methods must be 
practised with such soils, which will make it more compact and prevent the excessive circulation of air, reducing bacterial activities to what is best.

The reaction of a soil is its relative acidity, or "sourness" or alkalinity. The reaction means much from the bacterial standpoint. Soils which have become acid or sour are notably unproductive and this is largely due to the fact that the growth of beneficial bacteria in such soils is checked. Some bacteria are probably favored by acid conditions, but those organisms which bring about the solution of the important plant food constituents refuse to develop in acid soils. Such an unfavorable condition may be remedied by applications of ground limestone or caustic lime in varying amounts. Applications of ground limestone to sour soils have been shown to be followed by increased beneficial bacteria activities and later by increased crop production.

Bacteria require food for growth just as truly as do crops, and it is because of this need that they influence fertility. In the process of taking up food from the chemical compounds in the soil, the bacteria cause changes in the compounds, making them soluble and hence available for the growth of plants. Most soil bacteria live principally on organic matter, or humus, and the products of their own activity. Some few species are known which live in the absence of organic materials. Usually, however, soils without humus are without bacteria. Increasing the humus content, therefore, may be expected to increase the bacterial life. That is actually the case up to a certain limit, which varies widely for different soils.

Beyond a certain point, however, the amount of food 
ceases to govern bacterial growth and a lack of moisture or the presence of acidity or sourness may off set the benefits of a greater food supply. The minerals in the soil solution also have some influence on the bacteria. Certain groups are favored by some substances and others restricted or killed by certain other chemicals. Thus the bacterial floras of the soils of wet and dry regions are quite different.

The bacteria furthermore not only act on the humu: or organic matter in the soil and bring about its solution in the process of obtaining their food, but they also attack the mineral portion of the soil and change insoluble portions of that into soluble.

We have considered the fact that the fertility of a soil is determined very largely by the bacterial activities going on therein. We have discussed briefly the nature of bacteria, their form, size, multiplication, etc., the numbers present in the soil and the effect of various physical and chemical conditions in the soil on their development. We have found also that in the course of their life activities, bacteria attack the organic and mineral portions of the soil and transform insoluble constituents into forms soluble and available for crop nourishment.

In conclusion, the fact must be emphasized that the bacterial processes going on in the soil cannot be ignored in a consideration of its fertility. The physical and chemical character of the soil alone will not tell us its crop-producing power and we must depend on the results of tests of bacterial activities. The recent development of methods in this direction gives us reason to hope that in the near future bacterial tests 
of fertility may become of considerable practical value.

From the practical standpoint, it should be evident that the greatest care ought to be exercised on every farm to maintain conditions satisfactory for the best growth of beneficial bacterial species. Moisture conditions should be governed as far as possible by drainage or cultivation, aeration should be carefully regulated to keep the destruction of the humus from proceeding too rapidly; and the reaction of the soil should not be allowed to become acid, adding lime if necessary to prevent it. If these conditions are carefully governed and the humus content of the soils is properly maintained, and proper rotations containing a legume are employed, the bacteria can be depended upon to perform their part faithfully and well. If chemical analyses have shown sufficient amounts of the necessary mineral plant food constituents, the bacteria under the best conditions will transform it into an available form to satisfy the needs of the growing crop.

In short, the relation between bacteria and soil fertility is very close and very vital and systems of permanent agriculture must rest firmly on a bacteriological basis to be of value. 


\section{XXIV}

\section{WORMS AND THE SOIL}

\section{Charles Darwin}

Worms have played a more important part in the history of the world than most persons would at first suppose. In almost all humid countries they are extraordinarily numerous, and for their size possess great muscular power. In many parts of England a weight of more than ten tons of dry earth annually passes through their bodies and is brought to the surface on each acre of land; so that the whole superficial bed of vegetable mould passes through their bodies in the course of every few years. From the collapsing of the old burrows the mould is in constant though slow movement, and the particles composing it are thus rubbed together. By these means fresh surfaces are continually exposed to the action of the carbonic acid in the soil, and of the humus-acids which appear to be still more efficient in the decomposition of rocks. The generation of the humus-acids is probably hastened during the digestion of the many half-decayed leaves which worms consume. Thus the particles of earth, forming the superficial mould, are subjected to conditions eminently favorable for their decomposition and disintegration. Moreover, the particles of the softer rocks suffer some amount of mechanical trituration in 
the muscular gizzards of worms, in which small stones serve as mill-stones.

The finely levigated castings, when brought to the surface in a moist condition, flow during rainy weather down any moderate slope; and the smaller particles are washed far down even a gently inclined surface. Castings when dry often crumple into small pellets and these are apt to roll down any sloping surface. Where the land is quite level and is covered with herbage, and where the climate is humid so that much dust cannot be blown away, it appears at first sight impossible that there should be any appreciable amount of subaerial denudation; but worm castings are blown, especially whilst moist and viscid, in one uniform direction by the prevalent winds which are accompanied by rain. By these several means the superficial mould is prevented from accumulating to a great thickness; and a thick bed of mould checks in many ways the disintegration of the underlying rocks and fragments of rock.

The removal of worm castings by the above means leads to results which are far from insignificant. It has been shown that a layer of earth, two tenths of an inch in thickness, is in many places annually brought to the surface per acre; and if a small part of this amount flows, or rolls, or is washed, even for a short distance down every inclined surface, or is repeatedly blown in one direction, a great effect will be produced in the course of ages. It was found by measurements and calculations that on a surface with a mean inclination of $9^{\circ} 26^{\prime}$, two and four tenths cubic inches of earth which had heen ejected by worms crossed, in the course of a year, a horizontal line one yard in length; so 
that 240 cubic inches would cross a line 100 yards in length. This latter amount in a damp state would weigh 111/2 pounds. Thus a considerable weight of earth is continually moving down each side of every valley, and will in time reach its bed. Finally this earth will be transported by the streams flowing in the valleys into the ocean, the great receptacle for all matter denuded from the land. It is known from the amount of sediment annually delivered into the sea by the Mississippi, that its enormous drainage-area must on an average be lowered .00263 of an inch each year; and this would suffice in four and a half million years to lower the whole drainage-area to the level of the seashore. So that, if a small fraction of the layer of fine earth, two tenths of an inch in thickness, which is annually brought to the surface by worms, is carried away, a great result cannot fail to be produced within a period which no geologist considers extremely long. Archæologists ought to be grateful to worms, as they protect and preserve for an indefinitely long period every object not liable to decay, which is dropped on the surface of the land, by burying it beneath their castings. Thus, also, many elegant and curious tessellated pavements and other ancient remains have been preserved; though no doubt the worms have in these cases been largely aided by earth washed and blown from the adjoining land, especially when cultivated. The old tessellated pavements have, however, often suffered by having subsided unequally from being unequally undermined by the worms. Even old massive walls may be undermined and subside; and no building is in this respect safe, unless the foundations lie six 
or seven feet beneath the surface, at a depth at which worms cannot work. It is probable that many monoliths and some old walls have fallen down from having been undermined by worms.

Worms prepare the ground in an excellent manner for the growth of fibrous-rooted plants and for seedlings of all kinds. They periodically expose the mould to the air, and sift it so that no stones larger than the: particles which they can swallow are left in it. They mingle the whole intimately together, like a gardener who prepares fine soil for his ochoicest plants. In this state it is well fitted to retain moisture and to absorb all soluble substances, as well as for the process of nitrification. The bones of dead animals, the harder parts of insects, the shells of land-molluscs, leaves, twigs, etc., are before long all buried beneath the accumulated castings of worms, and are thus brought in a more or less decayed state within reach of the roots of plants. Worms likewise drag an infinite number of dead leaves and other parts of plants into their burrows, partly for the sake of plugging them up and partly as food.

The leaves which are dragged into the burrows as food, after being torn into the finest shreds, partially digested, and saturated with the intestinal and urinary secretions, are commingled with much earth. This earth forms the dark colored, rich humus which almost everywhere covers the surface of the land with a fairly well-defined layer or mantle. Von Hensen* placed two worms in a vessel eighteen inches in diameter, which was filled with sand, on which fallen leaves were strewed;

* "Zeitschrift für Wissenschaft," Zoolog. B. XXVIII. 1877, p. 360. 
and these were soon dragged into their burrows to a depth of three inches. After about six weeks an almost uniform layer of sand four tenths of an inch in thickness was converted into humus by having passed through the alimentary canals of these two worms. It is believed by some people that worm burrows, which often penetrate the ground almost perpendicularly to a depth of five or six feet, materially aid in its drainage; notwithstanding that the viscid castings piled over the mouths of the burrows prevent or check the rainwater directly entering them. They allow the air to penetrate deeply into the ground. They also greatly facilitate the downward passage of roots of moderate size; and these will be nourished by the humus with which the burrows are lined. Many seeds owe their germination to having been covered by castings; and others buried to a considerable depth beneath accumulated castings lie dormant, until at some future time they are accidentally uncovered and germinate.

Worms are poorly provided with sense-organs, for they cannot be said to see, although they can just distinguish between light and darkness; they are completely deaf, and have only a feeble power of smell; the sense of touch alone is well developed. They can therefore learn little about the outside world, and it is surprising that they should exhibit some skill in lining their burrows with their castings and with leaves, and in the case of some species in piling up their castings into tower-like constructions. But it is far more surprising that they should apparently exhibit some dey ree of intelligence instead of a mere blind instinctive impulse, in their manner of plugging up the mouths of 
their burrows. They act in nearly the same manner as would a man, who had to close a cylindrical tube with different kinds of leaves, petioles, triangles of paper, etc., for they commonly seize such objects by their pointed ends. But with thin objects a certain number are drawn in by their broader ends. They do not act in the same unvarying manner in all cases, as do most of the lower animals; for instance, they do not drag in leaves by their foot-stalks, unless the basal part of the blade is as narrow as the apex, or narrower than it.

When we behold a wide, turf-covered expanse, we should remember that its smoothness, on which so much of its beauty depends, is mainly due to all the inequalities having been slowly leveled by worms. It is a marvelous reflection that the whole of the superficial mould over any such expanse has passed, and will again pass, every few years through the bodies of worms. The plough is one of the most ancient and most valuable of man's inventions; but long before he existed the land was in fact regularly ploughed, and still continues to be thus ploughed by earth-worms. It may be doubted whether there are many other animals which have played so important a part in the history of the world, as have these lowly organized creatures. Some other animals, however, still more lowly organized, namely corals, have done far more conspicuous work in having constructed innumerable reefs and islands in the great oceans; but these are almost confined to the tropical zones. 


\section{XXV}

\section{THE STRUGGLE FOR EXISTENCE}

\section{Thomas H. Huxley}

When a variety has arisen, the conditions of existence are such as to exercise an influence which is exactly comparable to that of artificial selection. By conditions of existence I mean two things,--there are conditions which are furnished by the physical, the inorganic world, and there are conditions of existence which are furnished by the organic world. There is, in the first place, Climate; under that head I include only temperature and the varied amount of moisture of particular places. In the next place, there is what is technically called Station, which means, given the climate, the particular kind of place in which an animal or plant lives or grows ; for example, the station of a fish is in the water, of a fresh-water fish in fresh water; the station of a marine fish is in the sea, and a marine animal may have a station higher or deeper. So again with land animals: the differences in their stations are those of different soils and neighborhoods; some being best adapted to calcareous, and others to an arenaceous soil. The third condition of existence is Food, by which I mean food in the broadest s^nse, the supply of the materials necessary to the existence of an organic being; in the case of a plant the inorganic matters, such as carbonic acid, water, ammonia, and 
the earthy salts or salines; in the case of the animal the inorganic and organic matters, which we have seen they require; then these are all, at least the two first, what we may call the inorganic or physical conditions of existence. Food takes a mid-place, and then come the organic conditions; by which I mean the conditions which depend upon the state of the rest of the organic creation, upon the number and kind of living beings, with which an animal is surrounded. You may class these under two heads: there are organic beings, which operate as opponents, and there are organic beings which operate as helpers to any given organic creature. The opponents may be of two kinds: there are the indirect opponents, which are what we may call rivals: and there are the direct opponents, those which strive to destroy the creature; and these we call enemies. By rivals I mean, of course, in the case of plants, those which require for their support the same kind of soil and station, and, among animals, those which require the same kind of station, or food, or climate; those are the indirect opponents; the direct opponents are, of course, those which prey upon an animal or vegetable. The helpers may also be regarded as direct and indirect: in the case of a carnivorous animal, for cxample, a particular herbaceous plant may in multiplying be an indirect helper, by enabling the herbivora on which the carnivore preys to get more food, and thus to nourish the carnivore more abundantly; the direct helper may be best illustrated by reference to some parasitic creature, such as the tape-worm. The tape-worm exists in the human intestines, so that the fewer there are of men the fewer there will be of tape- 
worms, other things being alike. It is a humiliating reflection, perhaps, that we may be classed as direct helpers to the tape-worm, but the fact is so: we can all see that if there were no men there would be no tape-worms.

It is extremely difficult to estimate, in a proper way, the importance and the working of the conditions of existence. I do not think there were any of us who had the remotest notion of properly estimating them until the publication of Mr. Darwin's work, which has placed them before us with remarkable clearness; and I must endeavor, as far as I can in my own fashion, to give you some notion of how they work. We shall find it easiest to take a simple case, and one as free as possible from every kind of complication.

I will suppose, therefore, that all the habitable part of this globe-the dry land, amounting to about $51,000,000$ square miles,-I will suppose that the whole of that dry land has the same climate, and that it is composed of the same kind of rock or soil, so that there will be the same station everywhere; we thus get rid of the peculiar influence of different climates and stations. I will then imagine that there shall be but one organic being in the world, and that shall be a plant. In this we start fair. Its food is to be carbonic acid, water, and ammonia, and the saline matters in the soil, which are, by the supposition, everywhere alike. We take one single plant, with no opponents, no helpers, and no rivals; it is to be a "fair field, and no favor." Now, I will ask you to imagine further that it shall be a plant that shall produce every year fifty seeds, which is a very moderate number 
for a plant to produce; and that, by the action of the winds and currents, these seeds shall be equally and gradually distributed over the whole surface of the land. I want you now to trace out what will occur, and you will ohserve that I am not talking fallaciously any more than a mathematician does when he expounds his problem. If you show that the conditions of your problem are such as may actually occur in nature and do not transgress any of the known laws of nature in working out your proposition, then you are as safe in the conclusion you arrive at as is the mathematician in arriving at the solution of his problem. In science, the only way of getting rid of the complications with which a subject of this kind is environed, is to work in this deductive method. What will be the result, then? I will suppose that every plant requires one square foot of ground to live upon, and the result will be that, in the course of nine years, the plant will have occupied every single available spot in the whole globe! I have chalked upon the blackboard the figures by which $I$ arrive at the result:

\section{PLANTS}

PLANTS

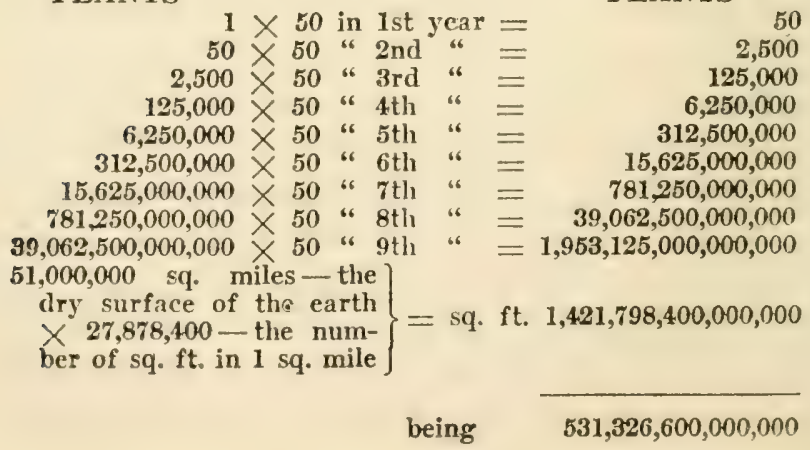


square feet less than would be required at the end of the ninth year.

You will see from this that at the end of the first year the single plant will have produced fifty more of its kind; by the end of the second year these will have increased to 2,500; and so on, in succeeding years, you get beyond even trillions; and I am not at all sure that I could tell you what the proper arithmetical denomination of the total number really is; but, at any rate, you will understand the meaning of all those noughts. Then you see that, at the bottom, I have taken the 51,000,000 of square miles, constituting the surface of the dry land; and as the number of square feet are placed under and subtracted from the number of seeds that would be produced in the ninth year, you can see at once that there would be an immense number more of plants than there would be square feet of ground for their accommodation. This is certainly enough to prove my point; that between the eighth and ninth years after being planted the single plant would have stocked the whole available surface of the earth.

This is a thing which is hardly conceivable-it seems hardly imaginable-yet it is so. It is indeed simply the law of Malthus exemplified. Mr. Malthus was a clergyman, who worked out this subject most minutely and truthfully some years ago; he showed quite clearly -and although he was much abused for his conclusions at the time, they have never yet been disprove! and never will be-he showed that in consequence of the increase in the number of organic beings in a geometrical ratio, while the means of existence cannot be made to increase in the same ratio, that there must come a time 
when the number of organic beings will be in excess of the power of production of nutriment, and that thus some check must arise to the further increase of those organic beings. At the end of the ninth year we have seen that each plant would not be able to get its full square foot of ground, and at the end of another year it would have to share that space with fifty others, the produce of the seeds which it would give off.

What, then, takes place? Every plant grows up, flourishes, occupies its square foot of ground, and gives off its fifty seeds; but notice this, that out of this number only one can come to anything; there are thus, as it were, forty-nine chances to one against its growing up; it depends upon the most fortuitous circumstances whether any one of these fifty seeds shall grow up and flourish, or whether it shall die and perish. This is what Mr. Darwin has drawn attention to, and called "The Struggle for Existence"; and I have taken this simple case of a plant because some people imagine that the phrase seems to imply a sort of fight.

I have taken this plant and shown you that this is the result of the ratio of the increase, the necessary result of the arrival of the time coming for every species when exactly as many members must be destroyed as are born; that is the incvitable ultimate result of the rate of production. Now, what is the result of all this? I have said that there are forty-nine struggling against every one; and it amounts to this, that the smallest possible start given to any one seed may give it an advantage which will enable it to get ahead of all the others; anything that will enable any one of these seeds to germinate six hours before any of the others 
will, other things being alike, enable it to choke them out altogether. I have shown you that there is no particular in which plants will not vary from each other; it is quite possible that one of our imaginary plants may vary in such a character as the thickness of the integument of its seeds; it might happen that one of the plants might produce seeds having a thinner integument, and that would enable the seeds of that plant to germinate a little quicker than those of any of the others, and those seeds would most inevitably extinguish the forty-nine times as many that were struggling with them.

I have put it in this way, but you see the practical result of the process is the same as if some person had nurtured the one and destroyed the other seeds. It does not matter how the variation is produced, so long as it is once allowed to occur. The variation in the plant once fairly started tends to become hereditary and reproduce itself; the seeds would spread themselves in the same way and take part in the struggle with the forty-nine hundred, or forty-nine thousand, with which they might be exposed. Thus, by degrees, this variety, with some slight organic change or modification, must spread itself over the whole surface of the habitable globe, and extirpate or replace the other kinds. That is what is meant by Natural Selection; that is the lind of argument by which it is perfectly demonstrable that the conditions of existence may play exactly the same part for natural varieties as man does for domesticated varieties. No one doubts at all that particular circumstances may be more farorable for one plant and less so for another, and the moment you admit that, you 
admit the selective power of nature. Now, although I have been putting a hypothetical case, you must not suppose that I have been reasoning hypothetically. There are plenty of direct experiments which bear. out what we call the theory of natural selection; there is extremely good authority for the statement that if you take the seed of mixed varieties of wheat and sow it, collecting the seed next year and sowing it again, at length you will find that out of all your varieties only two or three have lived, or perhaps even only one. There were one or two varieties which were best fitted to get on, and they have killed out the other kinds in just the same way and with just the same certainty as if you had taken the trouble to remove them. As I have already said, the operation of nature is exactly the same as the artificial operation of man.

But if this be true of that simple case, which I put before you, where there is nothing but the rivalry of one member of a species with others, what must be the operation of selective conditions, when you recollect as a matter of fact, that for every species of animal or plant there are fifty or a hundred species which might all, more or less, be comprehended in the same climate, food, and station; that every plant has multitudinous animals which prey upon it, and which are its direct opponents; and that these have other animals preying upon them; that every plant has its indirect helpers in the birds that scatter around its seeds, and the animals that manure it with their dung. I say, when these things are considered, it seems impossible that any variation which may arise in a species in nature should not tend in some way or other either to be a 
little better or worse than the previous stock; if it is a little better, it will have an advantage over and tend to extirpate the latter in this crush and struggle; and if it is a little worse, it will itself be extirpated.

I know nothing that more appropriately expresses this, than the phrase, "the struggle for existence": because it brings before your minds, in a vivid sort of way, some of the simplest possible circumstances connected with it. When a struggle is intense there must be some who are sure to be trodden down, crushed, and overpowered by others; and there will be some who just manage to get through only by the help of the slightest accident. I recollect reading an account of the famous retreat of the French troops, under Napoleon, from Moscow. Worn out, tired, and dejected, they at length came to a great river over which there was but one bridge for the passage of the vast army. Disorganized and demoralized as that army was, the struggle must certainly have been a terrible one-every one heeding only himself, and crushing through the ranks and treading down his fellows. The writer of the narrative, who was himself one of those who were fortunate enough to succeed in getting over, and not among the thousands who were left behind or forced into the river, ascribed his escape to the fact that he saw striding onward through the mass a great strong fellow-one of the French Cuirassicrs, who had on a large blue cloanand he had enough presence of mind to catch and retain a hold of this strong man's cloak. He says, "I caught hold of his cloak, and although he swore at me and cut at and struck me by turns, and at last, when he found he could not shake me off, fell to entreating me 
to leave go or I should prevent him from escaping, besides not assisting myself, I still kept tight hold of him, and would not quit my grasp until he had at last dragged me through." Here you see was a case of selective saving--if we may so term it-depending for its success on the strength of the cloth of the Cuirassier's cloak. It is the same in nature; every species has its bridge of Beresina; it has to fight its way through and struggle with other species; and when well nigh overpowered, it may be that the smallest chance, something in its color, perhaps-the minutest circumstance, -will turn the scale one way or the other.

Suppose that by a variation of the black race it had produced the white man at any time-you know that the Negroes are said to believe this to have been the case, and to imagine that Cain was the first white man, and that we are his descendants--suppose that this had ever happened, and that the first residence of this human being was on the West Coast of Africa. There is no great structural difference between the white man and the Negro, and yet there is something so singularly different in the constitutions of the two, that the malarias of that country, which do not hurt the black at all, cut off and destroy the white. Then you see there would have been a selective operation performed; if the white man had risen in that way he would have been selected out and removed by means of the malaria. Now there really is a very curious case of selection of this sort among pigs, and it is a case of selection of color, too. In the woods of Florida there are a great many pigs; and it is a very curious thing that they are all black, every one of them. Professor Wyman was 
there some years ago, and on noticing no pigs but these black ones, he asked some of the people how it was that they had no white pigs, and the reply was that in the woods of Florida there was a root which they called the Paint Root, and that if the white pigs were to eat any of it, it had the effect of making their hoofs crack, and they died; but if the black pigs ate any of it, it dir not hurt them at all. Here was a very simple case of natural selection. A skillful breeder could not morc carefully develop the black breed of pigs, and weed out all the white pigs, than the Paint Root does.

To show you how remarkably indirect may be such natural selective agencies as I have referred to, I will conclude by noticing a case mentioned by Mr. Darwin, and which is certainly one of the most curious of its kind. It is that of the Humble-Bee. It has been noticed that there are a great many more humble-bees in the neighborhood of towns, than out in the open country; and the explanation of the matter is this: the humble-bees build nests, in which they store their honey and deposit the larva and eggs. The field mice are amazingly fond of honey and larva; therefore, wherever there are plenty of field mice, as in the country, the humble-bees are kept down; but in the neighborhood of towns, the number of cats which prowl about the fields eat up the field mice, and of course the more mice tney eat up the less there are to prey upon the larve of the bees--the cats are therefore the indirect helpers of the bees.* Coming back a step farther we may say that

* The humble-bees, on the other hand, are direct helpers of some plants, such as the heartsease and red clover, which are fertilized by the visits of the bees; and they are indirect helpers of the numerous insects which are more or less completely supported by the heartsease and red clover.Author's Note. 
the old maids are also indirect friends of the humblebees, and indirect enemies of the field mice, as they keep the cats which eat up the latter. 'This is an illustration somewhat beneath the dignity of the subject, perhaps, but it occurs to me in passing, and with it I will conclude this lecture. 


\section{XXVI \\ ELECTRICITY ADVANCING FARM PROSPERITY *}

\section{James Burtow}

Ir Is a curious thing that farming, which is so allimportant to the very life of the nation, should have lagged so far behind in introducing labor-saving devices in its manifold activities. It is only recently that even a fraction of the attention given to manufacturing of ficiency has been paid to improving farm methods. Perhaps the chief factor which has played a part in such improvement has been the widespread development of electricity. City life is inconceivable without electricity and the time is rapidly approaching when the farmer cannot conduct his life and activities without all the aid which modern electrical science has placed at his disposal.

Probably the first consideration in installing electrical devices on the farm is the source of electric current. Now that electric power is being so generally used and is therefore being distributed over wide areas, it is usually possible for all except the most isolated farmers to obtain it from a central power station. This should be done whenever possible, as it is the less expensive way and the most satisfactory from every point of view. There is a minimum charge for service,

* From Export, American Industries, by permission. 
the cost of maintenance and upkeep is eliminated and the amount of power is not limited as it is in an isolated plant set up on an individual farm. In almost every case, if comparison is made in costs of getting power even from a distant station and in generating it on the farm, the advantage is distinctly in favor of the former method. If the isolated plant is absolutely unavoidable, an expert should be consulted who will make a survey of the conditions under which the plant will have to work and install a system which will be most practicable for the demands upon it. Cheapness should not be made the primary consideration when setting up a power plant, because in the long run the more expensive equipment pays for itself, and especially if the added cxpense has gone into increased equipment, future needs and expansion are thereby provided for.

Once supplied with electric power, by whatever means it is secured, the application of electricity to the farm is almost unlimited. In the dairy, electricity can be used to run the milking machines which are being employed more and more to meet the needs of modern sanitation. In every case where such machines have been installed they have brought about a saving in labor costs and economy in method. Two or three men can do the work which formerly required eight or ten, and a great deal more speed is possible than by the old method. Electricity can be applied to about twenty other dairy uses in addition to the milking machines. Cream separators and pasteurizers can be motor driven, and churns, bottle and can washers are other devices which can be most advantageously run by electricity. Refrigerating plants, so very necessary on the farm 
when ice is not available, and preferable to natural ice cooling in any case, can be ideally operated by electricity. Such a plant can be made automatic, thus regulating the refrigeration to order. Ice cutting is done away with; the space formerly occupied by ice can be used for store rooms and the cooling or cold storage is accomplished with the minimum of time, effort, and cost.

One of the most important applications of power to farm uses is that of the water pump. A one or two horse power motor will usually supply all the water needed for the farm and dairy and the pumping equipment can easily be made automatic so that no attention need be paid to it except to oil it at frequent intervals.

Barn and field machinery can be run by electricity to excellent advantage. Feed grinders, corn shellers, ensilage cutters, grain elevators, threshers and graders, hay hoists and balers, and a dozen other of the necessary farm engines are capable of electric application. By installing a motor at a central point, it can of ten be made to operate several machines simultaneously or, if power is limited, various different machines which are not used at the same time.

Recently some interesting experiments have been made in the use of electricity in the chicken business. Incubators and brooders can be kept warm by electric heat, and it is even said that hens can be induced to lay more frequently and regularly if kept in properly lighted hen houses, certainly a most useful application of the ever-useful electric light.

In the farm work, a small motor to operate grindstones, saws, drills, and blowers is very useful, and 
electric soldering irons and glue pots can be utilized in many ways of great value.

The advantages of electricity in the farm home are much the same as in a city home, but are perhaps more appreciated in the country because the demands upon the housewife's time are so much greater and the work she does is so much heavier than that of her city cousin. Now that domestic help is so difficult to secure, even in the cities, and much more so in the country, the farm woman must depend more and more upon herself and she will welcome any lightening of her labors that can be effected by electrical devices. Bread mixers, vacuum cleaners, washing machines, sewing machines, and water pumps are some of the most popular and labor-saving electrical appliances for the farm home.

These are but a few of the many uses to which electricity may be put on the farm, but they are enough to indicate its varied and widespread applications. The cost-always an important item-is small in comparison with the results accomplished. The low costs of electricity are amazing in any case. Electric light is one of the few things which has decreased in cost in the last few years, and the same is true, in lesser degree, of other forms of electricity. When one stops to consider that, at current rates, one cent's worth of electricity will operate a six-pound flatiron for fifteen minutes, drive an electric vacuum cleaner long enough to clean four hundred and fifty square feet of carpet, run a sewing machine or a twelve-inch fan for two hours, lift one hundred gallons of water one hundred feet, run a buffer and grinder for one and a quarter hours, or do a washer full of washing, the cost shrinks into insignif- 
icance and the advantages appear inestimable. 'Then, too, there is always this to be remembered, that the electric motor consumes power only when in actual operation and in direct proportion to the amount of work done. There is, therefore, no waste or extravagance involved.

A description of a model farm, so far as electric installation is concerned, will show the practical uses to which electricity may be put. This farm is in Iowa and in many ways is typical of the Middle Western farm. The buildings are all new and of modern construction and are electrically lighted throughout. Over the door of the garage is a lamp which lights the walks from house to barns and which can be controlled from four points. This does away with the use of the lantern as the light can be turned on before leaving the house and upon reaching the barn. In the main barn there is a seven and a half horse-power motor which drives a feed mill. This mill is practically automatic, as long as experience has shown just where to set the slide gate in the feed chute so that the mill receives the proper amount of unground oats or corn and it can be therefore run without any attention. Near the feedmill is a one horse-power motor belted to a shaft formerly driven by a wind-nill. 'This shaft runs outdoors to a pump which delivers water to a concrete tank from which pipes lead to the various wateringtroughs for the stock. One of these troughs is placed in the wall of the stock shed so that it can be reached from without or within. To prevent the water in the outside trough from freezing in cold weather, a small electric immersion heater has been installed which keeps 
the water above the freezing point and ready to drink. This device saves a great deal of work. There is a motor-driven feed cutter that prepares feed directly for use and does away with the need for storing ground feed in large quantities.

In the house there are electrical devices too, as the modern equipment is not confined to the farm equipment alone. There is a very complete electric lighting system and a plumbing installation supplied by a small rotary pump. This pump delivers water into a concrete pressure tank. In the laundry there is a combined washing machine and wringer driven by a small motor. The kitchen also has various electric devices. Not only are there the more usual devices such as an electric iron, a vacuum cleaner, and a sewing machine motor, but an electric cooking range, with three burners on top and an oven underneath. This range keeps the kitchen cool in summer and is useful in the winter if fuel for the coal range runs short or the fire goes out.

This farm has 320 acres, on which about 150 head of cattle and $\mathbf{3 0 0}$ hogs are fed. With the aid of the various electrical devices it is possible for the owner to take care of the stock in winter with the aid of one boy and in the summer to concentrate on the purely productive work of the farm. The electric bills run about ten dollars a month, a very low figure considering the amount of power and light used.

Electricity is undoubtedly the motive power of the future not only on the farm, but in every phase of existence where power is needed. To supply himself with it now only means that the farmer is anticipating his future needs besides providing the most desirable 
solution for all the present problems which have seemed so difficult on account of lack of suitable power facilities. Electricity can do much to lighten the daily toil-the sunrise-to-sunset ceaseless labor which has always been characteristic of farm work. In fact, it almost seems to be the panacea for all the troubles of the farmer. Farming accomplished by the touch of an. electric button seems a fairy tale, but who knows what the future may bring forth? Going back to the land may soon be the most desirable thing in the world instead of the worst, as sundry disgruntled farmers would have had us believe in the past. 


\section{XXVII}

\section{THE GASOLINE ENGINE ON THE FARM *}

\section{Xeno W. Putnam}

The world is asking for bread and the farmer must supply it. For that purpose he cultivates his lands. The call of the farmer is for eflicient helpers. There is a scarcity of workmen which is hampering him at every turn. It required 50,000 acres, some one has figured, to supply the meager necessities of a single savage, but less than twenty-five acres are available to supply the more exacting demands of each citizen to-day. Intensive culture alone can meet the demand; more work and better work on every available acre, and the call for extra helpers which cannot be answered with men must be met by machinery. The farmer of the future must be a mechanic rather than a day laborer. He will have time for little but the intellectual part of soil-tilling, while the manual labor will more and more of it be done with wheels and levers. Hand labor was long ago dispensed with in the mill and factory wherever possible because it is more expensive than the factory can afford. The farmer has adhered to the harder and more costly method and has performed work manually that some adequate farm power might have done better and cheaper.

* From "The Gasoline Engine on the Farm," by permission of The Norman W. Heuley Pub. Co. 
Many devices that might have reduced the labor of the farmer have never been placed upon the market, because all farm machinery formerly had to be restricted to the limits of the horse in power and speed. In this respect the farm implement designer has been more seriously hampered than any other class of inventors. Without the aid of steam and electricity our factories would still be in their infancy. How much the world has lost through its most important industry, agriculture, because of this unfortunate limit placed upon her field appliances can only be guessed at. Many valuable inventions have been abandoned because they had to be made too light or too slow for effective work, in order that they might be handled by the ordinary farm team.

The call of the farm is for power; some means by which the intelligence of a single man can direct a force that will do as much work as a dozen or a hundred men could do with their unaided hands. Farming has indeed advanced from the plane of simply making a living to that of a great commercial project. From plowing to shelling, it takes four and one half hours' work to raise one bushel of corn by hand. Machinery and power reduce this to forty-one minutes. The same commercial arguments which demand power in the factory render it even more necessary upon the farm.

Various forms of farm power have been tried and have failed. The tread-mill was not a real power, but a clumsy means of transmitting the limited energy of some animal. It was unsteady, hard to operate, and soon became a synonym for drudgery. Sweep power is hard to move, cumbersome, and usually required the 
exposure of its operators to every storm. The waterwheel is of very restricted application. It may easily fail in dry weather and, at best, cannot be moved about. IVind mills are objectionable for the same reason; also from the unreliable nature of their motive force. Stean alone has been the only serious competitor of the horse in general farm work; still it is not by any means the ideal farm power.

Much of the farmer's work is done in short runs and at many different places. His ideal power must be ready at a moment's notice and must not cost anything to maintain except while in use. It must be safe, reliable, easy to operate and portable: not easily disturber by weather conditions; available at any place, indoors or out. Electricity might avail for all of this excepting portability, were it more generally to be obtained upon the farm. It usually is not, unless produced by the borrowed energy of steam or gasoline engine at a good deal of waste in transmission or in transforming mechanical to electrical energy.

The gasoline engine is the only power at the present time that has answered all of these various demands. It is a wonderfully flexible power, adapting itself to all conditions. While the teams are being fed the engine may be started upon a day's run at the feed mill, then the operator is free to go back to breakfast. No fuel is used, as is the case with a steam boiler, while steam is raised. The operator needs no greater mechanical training than should be considered necessary to properly run a binder. If power is needed in the kitchen to operate the washing machine two men can pick the engine up and take it there. If wanted in the farthest 
corner of the wood lot it can be set on the farm wagon and conveyed there without the necessity of a second or third trip for water tank and fuel; neither is there a trail of feed-wires to erect. The driest and calmest weather does not disturb it, nor does it break away from its moorings in the fiercest wind. It can be obtained in one fourth horsepower sizes if required, while five thousand horsepower engines are in successful operation. It works properly in zero weather or excessive heat and functions no matter what the mercury registers.

The most convincing argument in the world is achievement. Let us see what the gasoline engine has actually done; what it is now doing on the farm. In parts of the West where best known, it is driving the steam tractor from the field; is plowing, harrowing, and seeding all in one operation, by the square mile instead of by the acre, and is doing the work better, as well as quicker and cheaper, than horsepower can do it. It is harvesting the grain when the fields are too soft to carry the ordinary binder and when the steam tractor would be helpless; then, after threshing, it is conveying a part to market and converting the balance into the most available form for feeding cattle. It is loading hay in the fields and then unloading it in the barns or placing it in stacks. Without fear of hunger or thirst, it turns away from its source of supplies and requires no procession of fuel and water wagons to follow upon its trail. If the season is short or the weather threatening, it turns the night into day with its own headlight and lives its working life in twenty-four hour days as cheerfully as in periods of eight or ten. Where necessary it has run without stopping from Monday morn- 
ing till Saturday night with hardly an hour's attention during the entire time.

The gasoline engine is irrigating fields and putting on the finishing touches of success where drought and failure threatened. It is annually saving to the world thousands of dollars' worth of fruit from the ravages of fungus and insect. It is digging the farmer's postholes; it is cutting his wood and hauling it to the sheds. It is taking out of farm life much of that drudgery which destroys human life more through dreariness than through expended energy. Perhaps its greatest value is in the every-day humble occupations, and from these it never shirks.

Unlike the general run of labor-saving instruments, the work of the gasoline engine is not completed in the field. It runs the washer and wringer for the housewife with ease, pumps the water for her, does the churning, skims the milk, and has even been known to sweep the floor, clean the carpet, wash the windows and the dinner dishes. In numberless ways, after doing the heavy field work, it has lightened the burden for some tired or semiinvalid housewife and added that touch of leisure or of beauty to the house or lawn so dear to the heart of the farm girl.

Between the gasoline engine and the boys of the farm there seems to be a special bond of sympathy that removes from the latter those terrors of wood-pile and grindstone that drove his older brother from the farm. It silences the call of the city by rendering farm life the more attractive of the two. The boy is progressive unless his ambition is crushed out with hard work. His school life feeds his ambition and the farm must either 
keep up with his love of progress or he will grow away from it. The engine is the boy's confidant and friend, for it develops in him that love of machinery upon which are based the world's achievements.

Modern farm work has outgrown the capacities of a single pair of hands. The hired man is a necessity ; but where the number of places needing him is greatly in excess of the supply of desirable men, it is but natural that the farm which is best equipped for the elimination of drudgery is most attractive to the most progressive men. The engine is making it more desirable by making it more efficient, by shifting the drudgery of physical routine to the alertness of applied intelligence; for drudgery always dulls the intellect and produces the lowest form of efficiency.

The gasoline engine has done all this; it is doing still more. Many of to-day's important industrial problems originate upon the farm and depend upon its productiveness, its extension, and its life for their solution. As the proportion of workers remaining on the farm becomes less, their importance to those who have left it becomes greater, and nothing raises the standard of civilization in any community so quickly as a decrease in the cost of power ; a conserving of human life by surrounding its workers with better conditions, which have been robbed of drudgery and no longer dwarf the intellectual man. The highest form of conservation applies to the world's men and women more than to her raw material. Manual labor has become too slow and it accomplishes too little; it cannot keep up with the demand. The only true economy in the use of human energy lies in putting it to some more productive work 
than that which a machine can do as well and twenty times as fast. The true place for the man himself is at the controlling lever, where more than automatic machine action is needed and where human intelligence rules supreme. This wonderfully universal and flexible power is placing the modern farmer's work on a higher plane and is turning former hit-or-miss methods of farming into a definite science.

In its one expression, the automobile, it has given farm intelligence its rightful place in the social world. It has broken down the false and undesirable social barriers that formerly existea between town and country life and which, in a great measure, have been responsible for the unpopularity of farm life among both city and country young people. To-day the best schools and lecture halls are placed within reach of the farm door, and country youth, surrounded at last by environments it craved, has made the most of them. After the hour of intellectual enjoyment they return to the farm still loyal to it, but with new ideals and a broader appreciation of life.

The farm house itself, stripped of its atmosphere of drudgery and grinding toil, becomes an actual home where culture is no longer impossible. Out of the added leisure springs an influence of affection and respect that makes the man live a better life because of the home life from which the boy received his training. 
OUR FOREFATHERS AND FARMING 



\section{XXVIII}

\section{THE RURAL SOCRATES *}

\section{H. C. Hirzel}

IT Is no longer a controvertible point, whether the science of agriculture merits the distinguished attention of philosophical minds, and is the proper study of the most enlarged understanding; since the proof is beyond contradiction, that a judicious rural economy is one of the chief supports of the prosperity of a State. We every day see instances in common life, where the happiest disposition, most informed genius, superior talents, scientific knowledge, even probity and virtue, become useless, and are lost in the wreck of their possessor's fortune, if he omits to regulate his domestic affairs by the rules of a wise and prudent economy. The same observation may he extended to the wisest systems of legislature, and the best political institutions, which lose their efficacy, and are incapable of defending a State from absolute ruin, unless a general scheme of economy, sensibly executed, provides for the subsistence of the people; either by finding within itself those productions requisite to the support of individuals, or exciting a spirit of industry to exchange with foreign nations the produce of manufactories, for the necessaries of life. There is something so seducing to

\footnotetext{
* From "Rural Economy." "The Rural Socrates," memoirs of a country philosopher, was published in the German and the Freach in the 18 th century.
} 
the imagination in this last method, that there is danger of suffering ourselves to be deceived, in giving it a preference to the former. Through the medium of commerce, manufactures invite into the country, where they flourish, not only the necessaries of life, but every superfluity of wealth and luxury. However parsimonious the hand of Nature may have been to such a country, it soon becomes more affluent than the most fertile soils, and increases in power and population almost miraculously. Yet, if agriculture remains neglected, all these advantages will be fluctuating and uncertain; while, on the contrary, where that is considered as the first object of national attention, it conducts directly and invariably to the end desired, without exposing us to the caprice of fortune. A State that amply produces the sustenance of its inhabitants from its own bowels, has, at least, the advantage of independency; while the richest nation, when obliged to have recourse to the assistance of foreigners for the necessaries of life, submits to all the vicissitudes of unforeseen events; and, in many instances, must be subservient to the cordial or unfriendly disposition of its neighbors.

Though the pride and absurdity of polite people have affected to treat it with ridicule and contempt, and even to degrade its followers as a very inferior race of beings; yet to speak of husbandmen as a society, they are, perhaps, more deserving of philosophical consideration and inspection, than any other society in the world! In the country, humanity presents itself to our view, in a state of innocent simplicity, resembling, in some degree, the state of nature. The distinct facul- 
ties and properties of the soul may be analyzed with greater ease, as they are less disguised and oppressed with a tinsel parade of artificial ornaments. A chain of reflection instructed me in this great truth, that intrinsic magnanimity of soul is unconfined to rank; and that the meanest condition furnishes instances of exalted sentiment and understanding, capable of contributing to the general good of the community. I was likewise convinced that in all situations the consciousness of a rational application of our talents, the rectitude and integrity of our actions, are the sources of that pure and tranquil joy which is the constant result and reward of virtue. Mankind is the same in all nations: the different gradations of genius are equally discernible in the cottage and the palace. I could trace among plowmen, the character of a Lycurgus, a Socrates, a Plato, a Homer, and a Lucian! Nor ought I to conceal, that the marks of vice were sometimes to be met with. The apparent distinction between these rustics and the fashionable part of the world seems to consist in the objects, not degree, of ratiocination. The country is the proper school for acquiring a more intimate knowledge of human nature: for forming just ideas of happiness, and for discerning what constitutes the true greatness of man. Here I learned to despise the ridiculous vanity of those literary geniuses, who fancy their extensive erudition places them in a superior order of beings; where, it is evident, their understanding is frequently clouded with prejudices, and their will, a slave to the dominion of the passions. This vanity, the excrescence of knowledge, is as contemptible as it is apparent to the eyes of a true 
philosopher. My sentiments now became more enlarged; all the disadvantageous descriptions of the manners and genius of those we call savages grew suspected, and I lamented our deficiency in relations of traveling philosophers, capable of investigating the secret recesses of the human heart, and contemplating the progress of nature, in her uncultivated off spring, with judicious and impartial observation. I am persuaded such remarks would throw new light on our enquiries into the different degrees of perfection in the intellectual faculty, and furnish the friends of human nature with materials for admiration and gratitude to the wisdom and goodness of the Creator in the order and disposition of His creatures. We should find that those nations whom we brand as savage, might, with much more propriety, retort the appellation on their polite guests, who forcibly dispossess them of wealth and liberty! Nor should we have any remaining doubts, whether those among them, who have participated of the manners and sciences of the Europeans, act conformably to sense, in seizing the first opportunity, with eagerness, of returning to the simple and rational life of their countrymen!

After the preference I have given to a rural life, in regard to the agreeable, as well as the uscful part, I trust the world will not condemn me, if, in those hours of relaxation which the busiest life allows, I return sometimes to what constituted the enjoyment of $\mathrm{my}$ routhful days. Surely I shall not incur its censure, for seeking to inculcate and extend some useful reflections, whose truth was then familiar to me; or for desiring to awaken in my fellow citizens a taste for so noble an 
employment, and offering them, in the improvement of their own estates, the means of essentially promoting the welfare of their country. Finally, may I not be permitted, with impunity, to relieve myself from the anxious fatigue inseparable from the practice of physic, by a recreation that tends manifestly to public emolument?

I must nevertheless acknowledge that the methods hitherto pursued do not appear to me the best calculated to answer the purposes of improvement. An eager pursuit after new experiments prevails among those whose knowledge of the ancient husbandry is superficial and incompetent. Some there are who flatter themselves with being considered as the great improvers of agriculture, from the introduction of some unknown species of corn, or artificial grass. There are others who expect fame from the invention of some new implement of tillage or different method of plowing and sowing; while still others hope to acquire it by untried objects of attention, such as the culture of mulberrytrees, for encouraging the breed of silk-worms, and so forth. In opposition to these opinions, I apprehend the first principle we ought to set out upon is a perfect knowledge of the nature of soils, with a competent insight of such methods of manuring as are practised by the most indefatigable and industrious farmers for the attainment of a degree of fertility. What remains is to procure a free communication of these discoveries in husbandry, and an endeavor, by all possible means, to incite a laudable and fervent emulation in the farmers. This I should think an eligible plan for restoring agriculture to a flourishing state. The most circumscribed 
genius may follow practical rules, unmolested by any obstacle; while new inventions are attended with a crowd of difficulties and objections. One part of mankind believe that, in adopting them, we insult the memory of our worthy progenitors, who, according to their way of reasoning, have transmitted to us the common methods of cultivating lands; and who, by their economy, love of labor, and many other respectable qualities, are deservedly objects of our imitation. Another part agree that the late discoveries are certainly very beneficial to particular countries, but repugnant to the nature of our soil. There are yet a third set of objectors who allow all these improvements to have advantages in particular respects; but assert that their superiority over the vulgar course of husbandry is so equivocal, they must, at least, be considered as of small utility. Instead of contenting ourselves with recommending the husbandry of our best farmers as a model for others, let them be encouraged to pursue it by the testimony and conviction of their own eyes. The experience necessary to assure them whether such or such methods are best adapted to the nature of the soil and climate is already attained, and the advantages arising from them easily calculated. Besides, that it cannot be disputed, notwithstanding what has been alleged of the general decline of agriculture among us, there are farmers in Switzerland who may be accused of anything rather than ignorance in husbandry. A more universal and generous diffusion of the knowledge of individuals seems all that is wanting to bring this art to perfection. The traveller who crosses the greater part of our cantons is amazed at 
the diversity of natural riches presented to his view, in a country so wild and romantic. It is scarcely conceivable how the inlabitants have been able to collect, within so limited a spot, the various productions of almost every part of Europe! He traverses the fields covered with waving corn, terminated at the right and left with vineyards; orchards of fruit conceal the villages from his sight; while he hears the distant sound of lowing herds and bleating flocks from the mountains that furnish them with food! I will even venture to affirm that many strangers may draw useful observations from the customs and practical regulations of our most distinguished farmers. Perhaps the paucity of writers in our own country may be the only reason for her not having acquired that reputation for rural economy which she enjoys with an uncontrolled title in all other branches of the arts.

I have no meaning on the other side to depreciate the merit of those noble-minded fellow citizens, who have appropriated a considerable part of the superfluity of their income to the procuring of new-invented implements of husbandry: several sorts of grain and grassseeds, trees and shrubs unknown in our climate, which have the experience of other countries in their favor, as well as the trials made before they were communicated. These public-spirited attentions, of whose good effects we have already reaped some advantage, undoubtedly merit our commendation and acknowledgment. The introduction of potatoes, turkey, corn, or maize, and the progress of preparing turf or peat for fuel, may be comprised in the number: yet this plan for the improvement of agriculture appears more uncertain 
and infinitely slower in its progress than that I have ventured to recommend. More uncertain, because men are tou apt to embellish a favorite theory in their writings. The species of regetation or method of manuring they are fond of is often extolled far beyond reality, and they give the reins to fancy in lavish descriptions of ideal excellence. It must be a long course of experiments that alone can determine whether this or that corn or grass may be naturalized with real benefit to a country, or the adoption of a new system of husbandry, with its attendant expense, be an advantageous compensation for abandoning the old one. Experiments commonly succeed to admiration in a wellcultivated garden or nursery ground; but when extended to large inclosures, the luxuriance of the produce is often greatly checked and diminished, and its utility absorbed in the expense of labor. I have also observed that new inventions are very slow in their effects, and can be of no real benefit till they become habitually established customs. It is a work of time to convince a peasant that the alterations you propose are eligible; to persuade him to a renunciation of rooted prejudices, and to desert the course of husbandry instilled into him by his forefathers, in favor of novelty and inexperience. 


\section{XXIX \\ EXTRACTS FROM A DIARY}

George Washington

A pril rith, 1785.-Cut two or three rows of the wheat (Cape wheat) within six inches of the ground, it being near eighteen inches high, that which was first sown, and the blades of the whole singed with the frost.

8th.- Sowed oats to-day in drills at Muddy Hole with my barrel plough. Ground much too wet; some of it had been manured, but had been twice ploughed, then listed, then twice harrowed before sowing; which, had it not been for the frequent rains, would have put the ground in fine tilth. Ploughed up the turnip patch at home for orchard grass.

10th.-Began bricklaying to-day. Completed sowing, with twenty-four quarts of oats, thirty-eight rows at Muddy Hole ten feet apart, in the ground intended for corn.

11th.- Sowed twenty-six rows of barley in the same field at Muddy Hole in the same manner, with the drill plough, and with precisely the same workings the oats had adjoining thereto. This was done with twelve quarts of seed. After three ploughings and three harrowings, sowed millet in eleven rows three feet apart, opposite to the overseer's house in the Neck. Per- 
ceived the last sowed oats at Dogue Run, and those sown in the Neck, were coming up.

12th.-Sowed sixteen acres of Siberian wheat, with cighteen quarts, in rows between corn, eight fect apart. This ground had been prepared in the following manner. (1) A single furrow: (2) another in the same to deepen it; (3) four furrows to throw the earth back into the two first, which made ridges of five furrows. These, being done some time ago, and the sowing retarded by frequent rains, had got hard; therefore, (4) before the seed was sown, these ridges were split again by running twice in the middle of them, both times in the same furrow; (5) after which the ridges were harrowed; and, (6) where the ground was lumpy, run a spiked roller with a harrow at the tail of it, which was found very efficacious in breaking the clods and pulverizing the earth, and would have done it perfectly, if there had not been too much moisture remaining from the late rains. After this, harrowing and rolling where necessary, the wheat was sown with the drill plough on the reduced ridges eight feet apart, as above mentioned, and harrowed in with the small harrow belonging to the plough. But it should have been observed, that, after the ridges were split by the middle double furrows, and before they were closed again by the harrow, a little manure was sprinkled in them.

At Dogue Run, listing the ground intended for Siberian wheat, barley, \&c., a second time.

At Muddy Hole sowed with the drill plough two rows of the Albany pease between the corn rows, to see whether they would come to anything for want of the support which they give one another when sown broad- 
cast. The same management given the ground as fo: oats and barley at this place.

13th.- Sowed oats in drills ten feet apart, between corn rows in the Neck, twenty-four rows, in the following manner. (1) A single furrow ; (2) another and deep furrow in this; (3) four bouts to these; (4) ploughed again in the same manner; (5) a single furrow in the middle of these; (6) manure sprinkled in this furrow; (7) the great harrow with the drill or barrel plough, and harrowed in with the harrow at the tail of it. Note.-It should have been observed, that the field intended for experiments at this plantation is divided into three parts, by bouting rows running crosswise; and that manure, and the last single furrow, are (at least for the present) bestowed on the most westerly of those nearest the Barn.

14th.-Harrowed the ground at Muddy Hole, which had been twice ploughed, for Albany pease in broadcast. At Dogue Run began to sow the remainder of the Siberian wheat, about fourteen quarts, which had been left at the Ferry; run deep furrows in the middle, and made five-feet ridges. Did the same for carrots in the same field on the west side next the meadow. Ordered a piece of ground, two acres, to be ploughed at the Ferry around the old corn-house, to be drilled with corn and potatoes between, each ten feet apart, row from row of the same kind. Sowed in the Neck, or rather planted, next to the eleven rows of millet, thirty-five rows of the rib-grass seeds, three feet apart, and one foot asunder in the rows.

15th.- Sowed six bushels of the Albany pease broadcast at Muddy Hole, on about an acre and a half of 
ground, which was harrowed yesterday as mentioned above.

Sowed in the Neck along side of the rib-grass fifty rows of burnet seed, exactly as the last was put in; that is, in three feet rows, and one foot in the row. 


\section{$\mathrm{XXX}$}

\section{A LETTER TO THOMAS JEFFERSON}

\section{George Washington}

\section{Mount Vernon, 4 October, 1795.}

Dear Sir,

I am much pleased with the account you have given of the succory. This, like all other things of the sort with me, since my absence from home, has come to nothing; for neither my overseers nor manager will attend properly to anything but the crops they have usually cultivated; and, in spite of all I can say, if there is the smallest discretionary power allowed them, they will fill the land with Indian corn, although even to themselves there are the most obvious traces of its baneful effects. I am resolved, however, as soon as it shall be in my power to attend a little more closely to my own concerns, to make this crop yicld in a degree to other grain, to pulses, and to grasses. I am beginning again with chiccory, from a handful of seed given me by Mr. Strickland, which, though flourishing at present, has no appearance of seeding this year. Lucerne has not succeeded better with me than with you; but I will give it another and a fairer trial before it is abandoned altogether. Clover, when I can dress lots well, succeeds with me to my full expectation, but not on the fields in rotation, although $I$ have been at much cost in seeding 
them. This has greatly disconcerted the system of rotation on which $\mathrm{I}$ had decided.

I wish you may succeed in getting good seed of the winter vetch. I have often imported it, but the seed never vegetated, or in so small a proportion, as to be destroyed by weeds. I believe it would be an acquisition, if it was once introduced properly in our farms. The Albany pea, which is the same as the field pea of Europe, I have tried, and found it will grow well; but is subject to the same bug which perforates the garden pea, and eats out the kernel. So it will happen, I fear, with the pea you propose to import. I had great expectation from a green dressing with buckwheat, as a preparatory fallow for a crop of wheat, but it has not answered my expectation yet. I ascribe this, however, more to mismanagement in the times of seeding and ploughing in, than any defect of the system. The first ought to be so ordered, in point of time, as to meet a convenient season for ploughing it in, while the plant is in its most succulent state. But this has never been done on my farms, and consequently has drawn as much from, as it has given to the earth. It has always appeared to me that there were two modes in which buckwheat might be used advantageously as a manure. One, to sow early, and, as soon as a sufficiency of seed is ripened, to stock the ground a second time, to turn the whole in, and when the succeeding growth is getting in full bloom, to turn that in also, before the seed begins to ripen; and, when the fermentation and putrefaction ceases, to sow the ground in that state, and plough in the wheat: The other mode is, to sow the buckwheat so late, as that it shall be generally about a foot high at 
the usual seeding of wheat; then turn it in, and sow thereon immediately, as on a clover lay, harrowing in the seed lightly to avoid disturbing the buried buckwheat. I have never tried the latter method, but see no reason against its succeeding. The other, as I observed above, I have prosecuted, but the buckwheat has always stood too long, and consequently had got too dry and sticky to answer the end of a succulent plant.

But of all the improving and ameliorating crops, none in my opinion is equal to potatoes, on stiff and hard bound land, as mine is. I am satisfied, from a variety of instances, that on such land a crop of potatoes is equal to an ordinary dressing. In no instance have I failed of good wheat, oats, or clover, that followed potatoes; and I conceive they give the soil a darker hue. I shall thank you for the result of your proposed experiment relative to the winter vetch and pea when'they are made.

I am sorry to hear of the depredations committed by the weevil in your parts; it is a great calamity at all times, and this year, when the demand for wheat is so great, and the price so high, must be a mortifying one to the farmers. The rains have been very general, and more abundant since the 1st of August, than ever happened in a summer within the memory of man. Scarcely a mill-dam, or bridge, between this and Philadelphia, was able to resist them, and some were carried off a second and third time.

Mrs. Washington is thankful for your kind remembrance of her, and unites with me in best wishes for you. With very great esteem and regard, I am, dear Sir, \&c 


\section{XXXI \\ LINCOLN ON AGRICULTURE *}

\section{Abraham Lincoln}

Members of the Agricultural Society and Citizens of Wisconsin: Agricultural fairs are becoming an institution of the country. They are useful in more ways than one. They bring us together, and thereby make us better acquainted and better friends than we otherwise would be. From the first appearance of man upon the earth down to very recent times the words "stranger" and "enemy" were quite or almost synonymous. Long after civilized nations had defined robbery and murder as high crimes, and had aflixed severe punishments to them, when practised among and upon their own people respectively, it was deemed no offense, but even meritorious, to rob and murder and enslave strangers, whether as nations or as individuals. Even yet, this has not totally disappeared. The man of the highest moral cultivation, in spite of all which abstract principle can do, likes him whom he does know much better than him whom he does not know. To correct evils, great and small, which spring from want of sympathy, and from positive enmity among strangers, as nations or as individuals, is one of the highest functions of civilization.

* Annual address before the Wisconsin State Agricultural Socioty, at Milwaukee, Wisconsin, September 30, 1859. As far as can be ascertained this is the only address Abraham Lincoln gave upon any agricultural sub. ject. From Lincoln's "Complete Works," by permission of the publishers, The Century Company. 
To this end our agricultural fairs contribute in no small degree. They render more pleasant, and more strong and more durable, the bond of social and political union among us. Again, if, as Pope declares, "happiness is our being's end and aim," our fairs contribute much to that end and aim, as occasions of recreation, as holidays. Constituted as man is, he has positive need of occasional recreation, and whatever can give him this associated with virtue and advantage, and free from vice and disadvantage, is a positive good. Such recreation our fairs afford. They are a present pleasure, to be followed by no pain as a consequence; they are a present pleasure, making the future more pleasant.

But the chief use of agricultural fairs is to aid in improving the great calling of agriculture in all its departments and minute divisions; to make mutual exchange of agricultural discovery, information, and knowledge; so that, at the end, all may know everything which may have been known to but one or to but few, at the beginning; to bring together especially all which is supposed to be not generally known because of recent discovery or invention.

And not only to bring together and to impart all which has been accidentally discovered and invented upon ordinary motive, but by exciting emulation for premiums, and for the pride and honor of success,of triumph, in some sort, - to stimulate that discovery and invention into extraordinary activity. In this these fairs are kindred to the patent clause in the Constitution of the United States, and to the department and practical system based upon that clause.

One feature, I believe, of every fair is a regular ad- 
dress. The Agricultural Society of the young, prosperous, and soon to be great State of Wisconsin has done me the high honor of selecting me to make that address upon this occasion-an honor for which I make my profound and grateful acknowledgment.

I presume I am not expected to employ the time assigned me in the mere flattery of the farmers as a class. My opinion of them is that, in proportion to numbers, they are neither better nor worse than other people. In the nature of things they are more numerous than any other class; and I believe there really are more attempts at flattering them than any other, the reason for which I cannot perceive, unless it be that they can cast more votes than any other. On reflection, I am not quite sure that there is not cause of suspicion against you in selecting me, in some sort a politician and in no sort a farmer, to address you.

But farmers being the most numerous class, it follows that their interest is the largest interest. It also follows that that interest is most worthy to be cherished and cultivated-that if there be inevitable conflict between that interest and any other, that other should yield.

Again, I suppose it is not expected of me to impart to you much specific information on agriculture. You have no reason to believe, and do not believe, that I possess it; if that were what you seek in this address, any one of your own number or class would be more able to furnish it. You, perhaps, do expect me to give some general interest to the occasion, and to make some general suggestions on practical matters. I shall attempt nothing more. And in such suggestions by me, quite 
likely very little will be new to you, and a large part of the rest will be possibly already known to be erroneous.

My first suggestion is an inquiry as to the effect of greater thoroughness in all the departments of agriculture than now prevails in the Northwest-perhaps I might say in America. To speak entirely within bounds, it is known that fifty bushels of wheat, or one hundred bushels of Indian corn, can be produced from an acre. Less than a year ago $I$ saw it stated that $a$ man, by extraordinary care and labor, had produced of wheat what was equal to two hundred bushels from an acre. But take fifty of wheat, and one hundred of corn, to be the possibility, and compare it with the actual crops of the country. Many years ago I saw it stated, in a patent-office report, that eighteen bushels was the average crop throughout the United States; and this year an intelligent farmer of Illinois assures me that he did not believe that the land harvested in that State this season had yiclded more than an average of eight bushels to the acre; much was cut, and then abandoned as not worth threshing, and much was abandoned as not worth cutting. As to Indian corn, and indeed, most other crops, the case has not been much better. For the last four years I do not believe the ground planted with corn in Illinois has produced an average of twenty bushels to the acre. It is true that heretofore we have had better crops with no better cultivation, but I bclieve it is also true that the soil has never been pushed up to one half of its capacity.

What would be the effect upon the farming interest to push the soil up to something near its full capacity? 
Unquestionably it will take more labor to produce fifty bushels from an acre than it will to produce ten bushels from the same acre; but will it take more labor to produce fifty bushels from one acre than from five? Unquestionably thorough cultivation will require more labor to the acre; but will it require more to the bushel? If it should require just as much to the bushel, there are some probable, and several certain, advantages in favor of the thorough cultivation. It is probable it would develop those unknown causes which of late years have cut down our crops below their former average. It is almost certain, I think, that by deeper plowing, analysis of the soils, experiments with manures and varieties of seeds, observance of seasons, and the like, these causes would be discovered and remedied. It is certain that thorough cultivation would spare half, or more than half, the cost of land, simply because the same product would be got from half, or from less than half, the quantity of land. This proposition is selfevident, and can be made no plainer by repetitions or illustrations. The cost of land is a great item, even in new countries, and it constantly grows greater and greater, in comparison with other items as the country grows older.

It also would spare the making and maintaining of inclosures for the same, whether these inclosures should be hedges, ditches, or fences. This again is a heavy item-heavy at first, and heavy in its continual demand for repairs. I remember once being greatly astonished by an apparently authentic exhibition of the proportion the cost of an inclosure bears to all the other expenses of the farmer, though I cannot remember exactly what 
that proportion was. Any farmer, if he will, can ascertain it in his own case for himself.

Again a great amount of locomotion is spared by thorough cultivation. Take fifty bushels of wheat ready for harvest, standing upon a single acre, and it can be harvested in any of the known ways with less than half the labor which would be required if it were spread over five acres. This would be true if cut by the old handsickle; true, to a greater extent, if by the scythe and cradle; and to a still greater extent, if by the machines now in use. These machines are chiefly valuable as a means of substituting animal-power for the power of man in this branch of farm-work. In the highest degree of perfection yet reached in applying the horsepower to harvesting, fully nine tenths of the power is expended by the animal in carrying himself and dragging the machine over the field, leaving certainly not more than one tenth to be applied directly to the only end of the whole operation-the gathering in of the grain, and clipping of the straw. When grain is very thin on the ground, it is always more or less intermingled with weeds, chess, and the like, and a large part of the power is expended in cutting these. It is plain that when the crop is very thick upon the ground, a larger proportion of the power is directly applied in gathering in and cutting it; and the smaller to that which is totally useless as an end. And what I have said of harvesting is true in a greater or less degree of mowing, plowing, gathering in of crops generally, and indeed of almost all farm-work.

The effect of thorough cultivation upon the farmer's own mind, and in reaction through his mind back upon 
his business, is perhaps quite equal to any other of its effects. Every man is proud of what he does well, and no man is proud of that he does not well. With the former his heart is in his work, and he will do twice as much of it with less fatigue; the latter he performs a little imperfectly, looks at it in disgust, turns from it, and imagines himself excecdingly tired-the little he has done comes to nothing for want of finishing.

The man who produces a good full crop will scarcely ever let a part of it go to waste; he will keep up the inclosure about it, and allow neither man nor beast to trespass upon it; he will gather it in due season, and store it in perfect security. Thus he labors with satisfaction, and saves himself the whole fruit of his labor. The other, starting with no purpose for a full crop, labors less, and with less satisfaction, allows his fences to fall, and cattle to trespass, gathers not in due season, or not at all. Thus the labor he has performed is wasted away, little by little, till in the end he derives scarcely anything from it.

The ambition for broad acres leads to poor farming, even with men of energy. I scarcely ever knew a mammoth farm to sustain itself, much less to return a profit upon the outlay. I have more than once known a man to spend a respectable fortune upon one, fail, and leave it, and then some man of modest aim get a small fraction of the ground, and make a good living upon it. Mammoth farms are like tools or weapons which are too heavy to be handled; ere long they are thrown aside at a great loss.

The successful application of steam-power to farmwork is a desideratum-especially a steam plow. It is 
not enough that a machine operated by steam will really plow. To be successful it must, all things considered, plow better than can be done with animalpower. It must do all the work as well, and cheaper; or more rapidly, so as to get through more perfectly in season; or in some way afford an advantage over plowing with animals, else it is no success. I have never seen a machine intended for a steam plow. Much praise and admiration are bestowed upon some of them, and they may be, for aught I know, already successful; but I have not perceived the demonstration of it. I have thought a good deal, in an abstract way, about a steam plow. That one which shall be so contrived as to apply the larger proportion of its power to the cutting and turning of the soil, and the smallest, to the moving itself over the field, will be the best one. A very small stationary engine would draw a large gang of plows through the ground from a short distance to itself; but when it is not stationary, but has to move along like a horse, dragging the plows after it, it must have additional power to carry itself; and the difficulty grows with what is intended to overcome it; for what adds power also adds size and weight to the machine, thus increasing again the demand for power.

Suppose you construct the machine so as to cut a succession of short furrows, say a rod in length, transversely to the course the machine is locomoting, something like the shuttle in weaving. In such case the whole machine would move north only the width of the furrow, while in length the furrow would be a rod from east to west. In such case a very large proportion of the power would be applied to the actual plowing. But in this, 
too, there would be difficulty, which would be the getting of the plow into and out of the ground, at the end of all these short furrows.

I believe, however, ingenious men will, if they have not already, overcome the difficulty I have suggested. But there is still another, about which I am less sanguine. It is the supply of fucl, and especially water, to make steam. Such supply is clearly practicable; but can the expense of it be borne? Steamboats live upon the water, and find their fuel at stated places. Steammills and other stationary steam-machinery have their stationary supplics of fucl and water. Railroad locomotives have their regular wood and water stations. But the steam plow is less fortunate. It does not live upon the water, and if it be once at a water-station, it will work away from it, and when it gets away cannot return without leaving its work, at a great expense of its time and strength. It will occur that a wagonand-horse team might be employed to supply it with fuel and water; but this, too, is expensive; and the question recurs, "Can the expense be borne?" When this is added to all other expenses, will not plowing cost more than in the old way?

It is to be hoped that the steam-plow will be finally successful, and if it shall be, "thorough cultivation"putting the soil to the top of its capacity, producing the largest crop possible from a given quantity of ground-will be most favorable for it. Doing a large amount of work upon a small quantity, it will be as nearly as possible stationary while working, and as free as possible from locomotion, thus expending its strength as much as possible in traveling. Our thanks, 
and something more substantial than thanks, are due to every man engaged in the effort to produce a successful steam-plow. Even the unsuccessful will bring something to light which, in the hands of others, will contribute to the final success. I have not pointed out difficulties in order to discourage, but in order that, being seen, they may be the more readily overcome.

The world is agreed that labor is the source from which human wants are mainly supplied. There is no dispute upon this point. From this point, however, men immediately diverge. Much disputation is maintained as to the best way of applying and controlling the labor element. By some it is assumed that labor is available only in connection with capital-that nobody labors, unless somebody else owning capital, somehow, by the use of it, induces him to do it. Having assumed this, they proceed to consider whether it is best that capital shall hire laborers, and thus induce them to work by their own consent, or buy them, and drive them to it, without their consent. Having proceeded so far, they naturally conclude that all laborers are naturally either hired laborers or slaves. They further assume that whoever is once a hired laborer, is fatally fixed in that condition for life; and thence again, that his condition. is as bad as, or worse than, that of a slave. This is the "mud-sill" theory. But another class of reasoners hold the opinion that there is no such relation between capital and labor as assumed; that there is no such thing as a free man being fatally fixed for life in the condition of a hired laborer; that both these assumptions are false, and all inferences from them groundless. They hold that labor is prior to, and independent of, capital ; that, 
in fact, capital is the fruit of labor, and could never have existed if labor had not first existed; that labor can exist without capital, but that capital could never have existed without labor. Hence they hold that labor is the superior-greatly the superior-of capital.

They do not deny that there is, and probably always will be, a relation between capital and labor. The error, as they hold, is in assuming that the whole labor of the world exists within that relation. A few men own capital; and that few avoid labor themselves, and with their capital hire or buy another few to labor for them. A large majority belongs to neither class-neither work for others, nor have others working for them. Even in all our slave states, except South Carolina, a majority of the whole people of all colors are neither slaves nor masters. In these free states, a large majority are neither hirers nor hired. Men, with their familieswives, sons, and daughters-work for themselves, on their farms, in their houses, and in their shops, taking the whole product to themselves, and asking no favors from capital on the one hand, nor of hirelings or slaves on the other. It is not forgotten that a considerable number of persons mingle their own labor with capital - that is, labor with their own hands and also buy slaves or hire free men to labor for them; but this is only a mixed, and not a distinct, class. No principal state is disturbed by the existence of this mixed class. Again, as has already been said, the opponents of the "mud-sill" theory insist that there is not, of necessity, any such thing as the free hired laborer being fixed to that condition for life. There is demonstration for saying this. Many independent men in this assembly 
doubtless a few years ago were hired laborers. And their case is almost, if not quite, the general rule.

The prudent, penniless beginner in the world labors for wages awhile, saves a surplus with which to buy tools or land for himself, then lavors on his own account another while, and at length hires another new beginner to help him. This, say its advocates, is free labor - the just, and generous, and prosperous system, which opens the way for all, gives hope to all, and energy, and progress, and improvement of condition to all. If any continue through life in the condition of the hired laborer, it is not the fault of the system, but because of either a dependent nature which prefers it, or improvidence, folly, or singular misfortune. I have said this much about the elements of labor generally, as introductory to a consideration of a new phase which that element is in process of assuming. The old general rule was that educated people did not perform manual labor. They managed to eat their bread, leaving the toil of producing it to the uneducated. This was not an insupportable evil to the working bees, so long as the class of drones remained very small. But now, especially in these free states, nearly all are educated-quite too nearly all to leave the labor of the uneducated in any wise adequate to the support of the whole. It follows from this that henceforth educated people must labor. Otherwise, education itself would become a positive and intolerable evil. No country can sustain in idleness more than a small percentage of its numbers. The great majority must labor at something productive. From these premises the problem springs, "How can labor and education be the most satisfactorily combined?" 
By the "mud-sill" theory it is assumed that labor and education are incompatible, and any practicable combination of them impossible. According to that theory, a blind horse upon a tread-mill is a perfect illustration of what a laborer should be-all the better for being blind, that he could not kick understandingly. According to that theory, the education of labcrers is not only useless but pernicious and dangerous. In fact, it is, in some sort, deemed a misfortune that laborers should have heads at all. Those same heads are regarded as explosive materials, only to be safely kept in damp places, as far as possible from that peculiar sort of firc which ignites them. A Yankee who could invent a strong-handed man without a head would receive the everlasting gratitude of the "mud-sill" advocates.

But free labor says, "No." Free labor argues that as the Author of man makes every individual with one head and with one pair of hands, it was probably intended that heads and hands should coöperate as friends, and that that particular head should direct and control that pair of hands. As each man has one mouth to be fed, and one pair of hands to furnish food, it was probably intended that that particular pair of hands should feed that particular mouth-that each head is the natural guardian, director, and protector of the hands and mouth inseparably connected with it; and that being so, every head should be cultivated and inproved by whatever will add to its capacity for perform:ing its charge. In one word, free labor insists on universal education.

I have so far stated the opposite theories of "mudsill" and "free-labor," without declaring any preference 
of my own between them. On an occasion like this, I ought not to declare any. I suppose, however, I shall not be mistaken in assuming as a fact that the people of Wisconsin prefer free labor, with its natural companion, education.

This leads to the further reflection that no other human occupation opens so wide a field for the profitable and agreeable combination of labor with cultivated thought, as agriculture. I know nothing so pleasant to the mind as the discovery of anything that is at once new and valuable-nothing that so lightens and sweetens toil as the hopeful pursuit of such discovery. And how rast and how varied a field is agriculture for such discovery! The mind, already trained to thought in the country school, or higher school, cannot fail to find there an exhaustless source of enjoyment. Every blade of grass is a study; and to produce two where there was but one is both a profit and a pleasure. And not grass alone, but soils, seeds, and seasons-hedges, ditches, and fences-draining, droughts, and irrigation-plowing, hoeing, and harrowing-reaping, mowing, and threshing-saving crops, pests of crops, diseases of crops, and what will prevent or cure them-implements, utensils, and machines, their relative merits, and how to improve them-hogs, horses, and cattle-sheep, goats, and poultry-trees, shrubs, fruits, plants, and flowers-the thousand things of which these are specimens-each a world of study within itself.

In all this, book-learning is available. A capacity and taste for reading gives access to whatever has already been discovered by others. It is the key, or one of the keys, to the already solved problems. And not 
only so: it gives a relish and facility for successfully pursuing the unsolved ones. The rudiments of science are available, and highly available. Some knowledge of botany assists in dealing with the vegetable world-with all growing crops. Chemistry assists in the analysis of soils, selection and application of manures, and in numerous other ways. The mechanical branches of natural philosophy are ready help in almost everything, but especially in reference to implements and machinery.

The thought recurs that education - cultivated thought - can best be combined with agricultural labor, or any labor, on the principle of thorough work; that careless, half performed, slovenly work makes no place for such combination; and thorough work, again, renders sufficient the smallest quantity of ground to each man; and this, again, conforms to what must occur in a world less inclined to wars and more devoted to the arts of peace than heretofore. Population must. increase rapidly, more rapidly than in former times, and ere long the most valuable of all arts will be the art of deriving a comfortable subsistence from the smallest area of soil. No community whose every member possesses this art, can ever be the victim of oppression in any of its forms. Such community will be alike independent of crowned kings, money kings, and land kings.

But, according to your program, the awarding of premium awaits the closing of this address. Considering the deep interest necessarily pertaining to that performance, it would be no wonder if I am already heard with some impatience. I will detain you but a moment longer. Some of you will be successful, and 
such will need but little philosophy to take them home in cheerful spirits; others will be disappointed, and will be in a less happy mood. To such let it be said, "Lay it not too much to heart." Let them adopt the maxim, "Better luck next time," and then by renewed exertion make that better luck for themselves.

And by the successful and unsuccessful let it be remembered that while occasions like the present bring their sober and durable benefits, the exultations and mortifications of them are but temporary; and that the rictor will soon be vanquished if he relax in his exertion: and that the vanquished this year may be victor the next, in spite of all competition.

It is said an Eastern monarch once charged his wise men to invent him a sentence to be ever in view, and which should be true and appropriate in all times and situations. They presented him the words, "And this, too, shall pass away." How much it expresses! How chastening in the hour of pride! How consoling in the depths of affiction! "And this, too, shall pass away." And yet, let us hope, it is not quite true. Let us hope, rather, that by the best cultivation of the physical world beneath and around us, and the best intellectual and moral world within us, we shall secure an individual, social, and political prosperity and happiness, whose course shall be onward and upward, and which, while the earth endures, shall not pass away. 


\section{XXXII}

\section{THE EXCELLENCES OF AGRICULTURE *}

\section{XENOPHON}

"This anecdote I relate to you Critobulus," continued Socrates, "to show that not even men of the most exalted fortune are contented to abstain from agriculture; for the pursuit of it seems to be at once a means of enjoyment and of increasing their resources; and it is also an exercise for the body, such as to strengthen it for discharging the duties that become a man of honorable birth. In the first place, the earth yields the food on which men live to those who cultivate it, and produces in addition things from which they receive gratification. Besides these, it supplies the flowers which decorate altars and statues, and with which men adorn themselves, accompanied with the most pleasing odors and appearances; sauces and animal food, too, it partly produces and partly nourishes, in abundance (for the art of managing cattle is connected with farming); so that men have enough to propitiate the gods by sacrificing, and to use themselves. Yet, though it offers blessings in the greatest plenty, it does not permit us to take them in idleness, but requires us to accustom ourselves to endure the colds of winter and the heats of summer; to those whom it exercises in manual labor, it

* From Xenophon's Economics. Translated by the Rev. J. S. Wistson. 
gives an increase of strength; and in such as only oversce the cultivation of it, it produces a manly vigor, by requiring them to rise early in the morning, and forcing them to move about with activity; for in the country, as well as in the city, the most important matters are always done at a stated season. Again, if a man wishes to serve his country as a horse-soldier, farming offers the greatest convenience for keeping a horse, or if as a foot-soldier, it keeps the body robust; and it also affords some incitement to exertion in hunting over the land, supplying facilities for keeping of dogs, and supporting beasts of game. The horses and dogs, moreover, which are kept by farming, benefit the farm in return; the horse by carrying his master early in the morning to the scene of his labors, and furnishing him the means of returning late; the dogs by preventing the wild beasts from destroying the fruits of the earth and the cattle, and by affording security even in the most solitary places.

"The possession of land also stimulates agriculturists, in some degree, to defend their country in arms, as the ground produces its fruits exposed to all, for the strongest to take possession of them. What occupation, too, renders men more fit for running, and throwing, and leaping, than agriculture? What employment offers men greater gratification for their labor? What art welcomes the student of it with greater pleasure, offering him that approaches, indeed, the means of gaining whatever he desires? What occupation receives strangers with richer hospitality? Where is there greater facility for passing the winter amid plenty of fires, and warm baths, than on the farm? Or where can 
we spend the summer more agreeably, by streams, amid breezes, and under shade, than in the fields? What other occupation offers more pleasing first-fruits to the gods, or richer banquets on festival days? What pursuit is more comfortable for a man's servants, more delightful to his wife, more attractive to his children, or more gratifying to his friends? I should be surprised, for my own part, if any man of liberal feelings has met with any possession more pleasing than a farm, or discovered any pursuit more attractive, or more conducive - to the means of life, than agriculture.

"The earth also kindly teaches men justice, at least such as are able to learn; for it is those who treat her best that she recompenses with the most numerous benefits.

"If on any occasion, moreover, those who are cmployed in agriculture are forced to quit their occupations by a multitude of invading enemies, yet, as they have been bred to vigorous and manly exertion, and are well exercised in mind and body, they may, if the gods are not unfavorable, make incursions into the lands of those who impede their occupations, and carry off booty on which they may support themselves. Frequently, indeed, in war, it is safer to seek a livelihood with hostile weapons than with instruments of agriculture.

"The cultivation of the ground, too, instructs men to assist one another; for as we must make attacks on enemies with the aid of men, so it is with aid of men that agriculture must be conducted. He, therefore, that would till his ground properly must provide himself with laborers both ready to work and willing to 
obey him; and he that leads an army against an enemy must take similar precautions, rewarding those who act as good soldiers ought to act, and punishing those who are neglectful of discipline. A husbandman must encourage his workmen as frequently as a general exhort; his soldiers; and slaves require favorable prospects to be held out to them not less than freemen, and indeed even more, that they may be willing to stay with their masters. He also said well, who pronounced agriculure to be the mother and nurse of other arts; for when agriculture flourishes, all other pursuits are in full vigor; but when the ground is forced to lie barren, other occupations are almost stopped, as well by land as by sea."

When Critobulus had heard these remarks to an end, he said, "You seem to me, my dear Socrates, to say all this with great reason; but you have not observed that there are connected with agriculture many things which it is impossible for man to foresee; for sometimes hail, frost, drought, violent rains, mildew, and often indeed other causes, deprive us of the fruit of what has been excellently contrived and arranged; and sometimes disease comes to carry off, in the most pitiable manner, cattle that have been bred with the utmost care."

Socrates, listening to this, said, "I thought that you were aware, Critobulus, that the gods are disposers of affairs in agriculture not less than of those in war; and you see, I suppose, that those who are engaged in the field of battle propitiate the gods before they come to an engagement, and consult them, with the aid of sacrifices and auguries, to learn what they ought or ought not to do. And do you think that there is less necessity 
394 ESSAYS ON AGRICULTURE

to seek the favor of the gods with regard to the proceedings of agriculture? For be assured," added he, "that wise men worship the gods with a view to the preservation of their fruits, as well succulent as dry, and of their oxen, horses, sheep, and all their other possessions." 


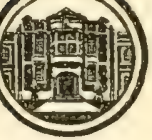

THE COUNTRY LIFE PRESS

GARDEN CITY, N. $Y$. 










\section{LIBRARY OF CONGRESS |||||||||||||||||||||||||||||||||||||||||||||||||||||||||||||| 口0027484153}

